\title{
A ADESÃO AO PROGRAMA DE CONTROLE DA TUBERCULOSE NO DISTRITO SANITÁRIO DO BUTANTÃ, SÃO PAULO
}

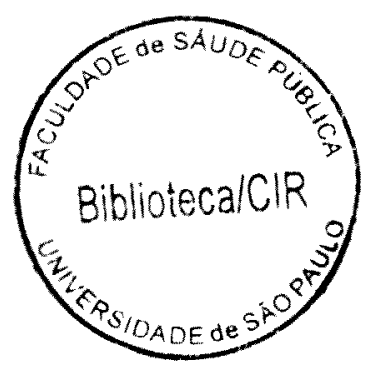

Tese apresentada ao Departamento de Epidemiologia da Faculdade de Saúde Pública da Universidade de São Paulo para obtenção do título de Doutor

Prof. Orientador: Prof. Dr. Gilberto R. Arantes

Profa. Co-orientadora: Prof. Dra. Marilia Belluomini 


\section{Nada é impossivel de mudar}

$$
\begin{array}{r}
\text { Desconfiai do mais trivial, } \\
\text { na aparência singelo. } \\
\text { E examinai, sobretudo, o que parece habitual. }
\end{array}
$$

Suplicamos expressamente: não aceiteis o que é de hábito como coisa natural, pois em tempo de desordem sangrenta, de confusão organizada, de arbitrariedade consciente, de humanidade desumanizada, nada deve parecer natural, nada deve parecer impossivel de mudar.

Bertold Brecht 
Ao Francisco,

minha vida.. 
Aos meus pais,

pelo apoio incondicional 


\section{AGRADECIMENTOS}

Muitos foram aqueles que integraram o processo pelo qual resulta o presente trabalho. Mesmo assim, gostaria de deixar explícitos meus sinceros agradecimentos àqueles que de alguma forma contribuíram mais diretamente para o seu desenvolvimento.

Ao Prof. Dr. Gilberto Ribeiro Arantes, orientador, pelo inestimável conhecimento que sempre tentou difundir a respeito da tuberculose.

À Profa. Dra. Marilia Belluomini, pelo constante apoio, carinho e disponibilidade.

À Profa. Dra. Emiko Yoshikawa Egry, sempre presente na minha trajetória como enfermeira, pesquisadora e docente, pelo estímulo constante, pelo valioso conhecimento e por ensinar-me a lutar em defesa da Saúde Coletiva.

À Prof. Dra. Marcia Regina Car, pelo suporte na decodificação dos depoimentos e pela amizade.

À Profa. Dra. Maria Amélia de Campos Oliveira, pela solidariedade, pela seriedade no cotidiano e pelas horas preciosas que dispendeu na leitura deste trabalho, apontando as críticas necessárias.

À Prof. Dra. Rosa Maria Godoy Serpa da Fonseca, pelo carinho e por acreditar no meu trabalho.

Às Professoras Anna Maria Chiesa, Renata Ferreira Takahashi e Rosangela Maria Greco, eternas amigas. 
À demais professoras do Departamento de Enfermagem em Saúde Coletiva, da Universidade de São Paulo, por suportar muitas vezes a carga de trabalho que a mim cabia, pelo estímulo, conforto e solidariedade nos momentos mais dificeis,

Aos colegas da Escola de Enfermagem da Universidade de São Paulo, em especial à Marisa Salles, Luciana Sanches Silva, Andréia Roma da Costa, Ricardo Matos Castellani, Ana Maria Sanchez Garcia e Terezinha Amaro dos Reis Alves, por apoiar-me sempre que necessário.

À Maria Aparecida Mendes, do Serviço de Aprimoramento da Faculdade de Saúde Pública da Universidade de São Paulo, por todo o apoio e disponibilidade, nos momentos mais dificeis.

Aos trabalhadores de saúde do Núcleo de Epidemiologia do Distrito Sanitário do Butantã, pelo apoio logístico necessário para a fase de coleta dos dados.

Às pessoas que compõem a população de estudo, pelo carinho com que me receberam, dispendendo horas de seu tempo valioso, e que me ensinaram o quanto se pode relativizar a vida, em função das condições em que vivem.

À todos os demais que me ouviram e ampararam nesse longo processo. 


\section{ÍNDICE}

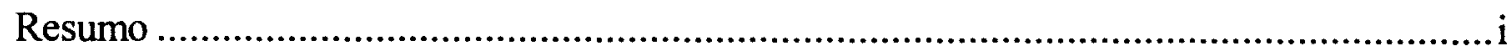

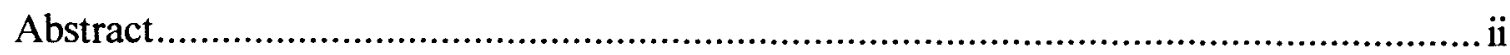

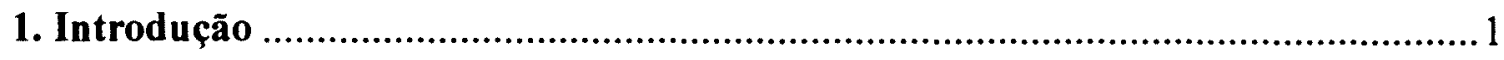

1.1. O perfil epidemiológico da tuberculose na atualidade ..............................................

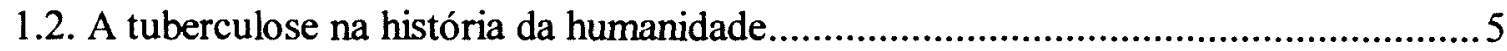

1.3. As politicas de controle da tuberculose no Brasil................................................... 12

1.4. A questão da adesão ao Programa de Controle da Tuberculose ................................ 18

1.4.1. O fracasso do programa de controle da tuberculose: quando a

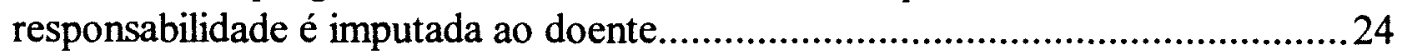

1.4.2. As limitações do programa de controle da tuberculose: quando outras questões entram em cena........................................................................30

1.4.3. As proposições para a mudança da realidade segundo a literatura..........................31

2. Objetivos

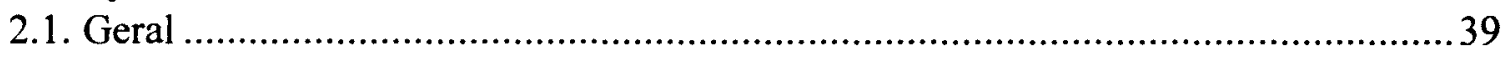

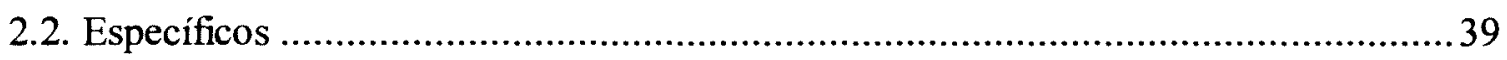

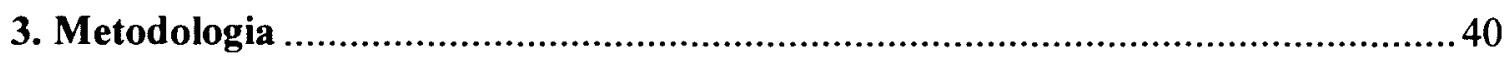

3.1. A opção metodológica: considerações gerais.........................................................40

3.2. O percurso metodológico...........................................................................5

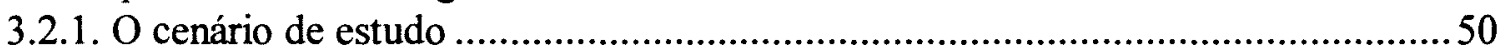

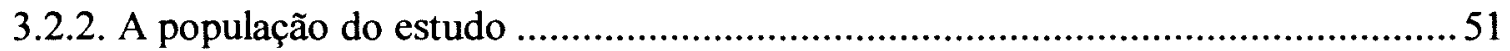

3.2.3. As sub-categorias relativas ao perfil geral dos clientes .......................................52

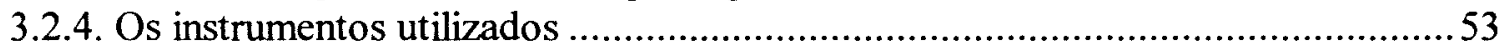

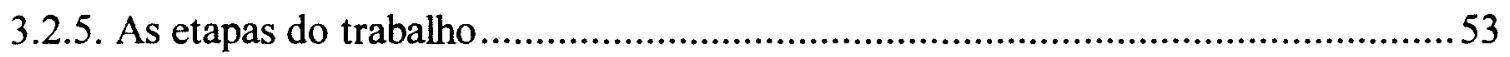

3.2.6. A decomposição dos discursos dos sujeitos........................................................57

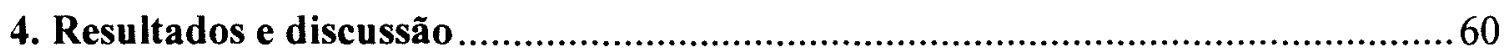

4.1. A descrição do perfil de características pessoais: quem eram e como

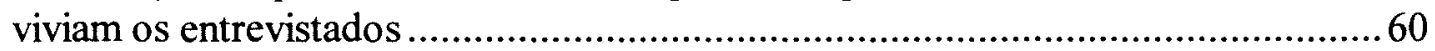

4.2. As representações dos doentes.........................................................................64

4.2.1. Representações sobre o processo saúde-doença ...................................................65

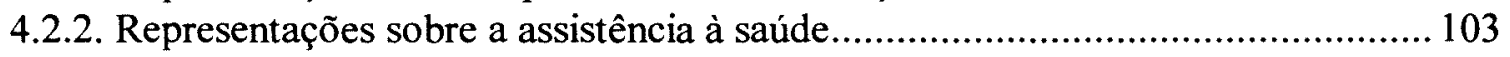

4.2.3. Representaçø̃es sobre o tratamento …………………..................................... 144

4.2.3.1. Representações sobre a adesão ao tratamento …………………………….... 159

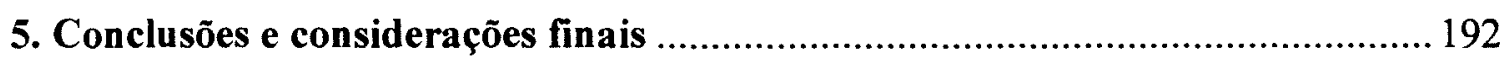

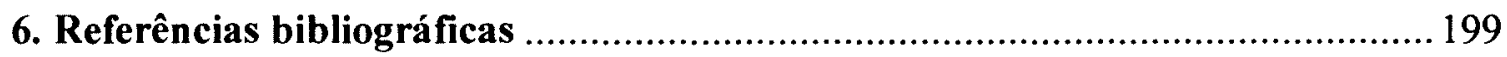

7. Anexos 


\section{RESUMO}

A ressurgência mundial da tuberculose em decorrência da sua associação com a AIDS, da progressiva multirresistência às drogas utilizadas, da crescente deterioração das condições de vida e de acesso à saúde de certos segmentos sociais, bem como as baixas taxas de adesão ao tratamento vêm colocando em pauta o desafio de revisitar os princípios técnicos, éticos e legais das medidas de controle tradicionalmente utilizadas. Em vista disso, esta investigação tem como objetivo analisar a questão da adesão ao Programa de Controle da Tuberculose (PCT) em São Paulo (SP), especificamente quanto ao tratamento medicamentoso, através da identificação das representações dos doentes sobre o processo saúde-doença, a assistência prestada e o tratamento, verificando quais os processos que levam os doentes a concluí-lo. Foram estudados 18 depoimentos de egressos do PCT, de unidades de saúde do Distrito Sanitário do Butantã-SP, de abril de 1995 a abril de 1996. A análise do material empírico foi feita à luz de duas vertentes teóricas, a Teoria das Necessidades e a Teoria da Determinação Social do Processo Saúde-doença, operacionalizadas através de técnica que põe em evidência os sentidos e os significados das ações contidas nos discursos, buscando-se a apreensão da lógica subjacente. Os resultados evidenciam que a inserção no processo de produção, parece influenciar o modo como os sujeitos vivenciam a doença e a adesão ao PCT. O imaginário em relação à doença, bem como o comportamento do doente parecem estar ligados à forma como a sociedade impõe atitudes e normas com respeito à tuberculose. Como produto da relação das pessoas com o trabalho e a vida, os doentes lidam com a enfermidade estabelecendo projetos de vida, nos quais a superação da doença é um objetivo a ser alcançado e a razão pela qual se concretiza a adesão ao tratamento. A adesão também está associada à forma como se processa a assistência à saúde, dependendo da organização dos processos de trabalho nas unidades de saúde. $O$ atendimento às necessidades das pessoas, transcendendo a dimensão biológica, possibilitando um espaço de interlocução entre o trabalhador de saúde e o doente, constitui o alicerce que vai determinar o engajamento no tratamento. $O$ respaldo que $o$ sujeito enfermo pode dispor nos âmbitos da família, do trabalho e na assistência também coloca-se como suporte para a adesão, pois constitui-se como espaço para a compartilha e o enfrentamento do processo saúde-doença. Os resultados apontam para a necessidade de que o PCT seja revisto, no que se refere ao estabelecimento de políticas públicas que coloquem em evidência a reorientação da produção da saúde, contemplando as necessidades de saúde do doente e da coletividade. 


\begin{abstract}
The deterioration of social life conditions, the spreading of social inequalities, the increase of AIDS, the progressive drug multiresistance, as well as the patients pauciadherence to the treatment play na important role in the resurgence of tuberculosis. This study was conducted in order to analyse the clients adherence process to the Tuberculosis Control Program (TCP) in São Paulo City (Brazil) to know the reasons and the ways that lead them to adhere to the treatment. Individual interviews of 18 clients from the health centers were made from April 1995 to April 1996. The Needs Theory and the Social Production of Health-Disease Process Theory performed the theoretical basis to analyse the speechs, through the aplication of technical procedures that permits to understand the sense and the means of the clients actions. The results allowed to reveal that the client's social allocation in the social production process influences the disease conception and the adherence to the TCP. Attitudes and behaviours assumed in relation to the tuberculosis are determined according to the ways that society historically built the disease social image. The adherence is linked to specific projects or goals established by the clients, which are related to their labor and their life. Also, the adherence depends on the technical organization of the labor process in health field. Attending the clients social needs, more than to the simple biologic restricted needs is one of the essential tools to guarantee the adherence. The support from families, the major labor staff and from the health workers is crucial to the adherence too, because it creates spaces to share and to face the disease and the difficulties that emerge from the treatment. The main results of this research claims to revisal the TCP in order to look for changes in the health production process focusing on the patient and the population health needs and to re-orient the public policies to put tuberculosis program as a priority in the health agenda.
\end{abstract}




\section{APRESENTAÇÃO}

A presente investigação refere-se ao estudo da adesão de clientes ao Programa de Controle da Tuberculose (PCT) estabelecido pelo Ministério da Saúde do Brasil. A temática é fruto de uma série de indagações que emergiram durante a realização das atividades profissionais da autora na prática da assistência em Unidades Básicas de Saúde (UBS), bem como do desenvolvimento do estudo realizado no início da década de 90, quando se buscou identificar como as pessoas com tuberculose pulmonar concebiam a assistência prestada (BERTOLOZZI, 1991). Pretendia-se, nessa época, a partir da identificação dos problemas oriundos do atendimento à saúde, propor alternativas que contribuíssem para a transformação da sua qualidade nos serviços de saúde de um dado Município do Estado de São Paulo. O desenvolvimento daquele estudo permitiu perceber as dificuldades que se colocam para os doentes durante todo o processo de tratamento, bem como questões mais gerais, que têm lugar no cotidiano da assistência à saúde. Tornou-se especialmente evidente que a magnitude da tuberculose transcende as ações de saúde que integram o Programa de Controle da Tuberculose, articulando-se aos processos de ordem estrutural, que se referem ao estabelecimento das políticas públicas sociais e de saúde pelo Estado. Além disso, tanto a prática da assistência à saúde, como dados de literatura revelam que a ressurgência da tuberculose, a adesão ao Programa de Controle da enfermidade e, mais especificamente, ao tratamento da doença, têm se constituído em um dos principais problemas epidemiológicos do momento atual, não só no Brasil, mas também em outros países, conforme será posteriormente abordado.

Buscar contribuir para o preenchimento dessa lacuna, através da apreensão da forma como se coloca a adesão para as pessoas que percorreram a trajetória da tuberculose constitui a finalidade desta pesquisa. Para tanto, o referencial que a embasa foi construido de forma tal que recupera alguns elementos da estrutura social, assim como a forma em que a epidemiologia da tuberculose está configurada, bem como as estratégias para o controle da doença que foram sendo historicamente adotadas. Para facilitar o entendimento da lógica de construção do referencial, ela será exposta através das vertentes a seguir discriminadas. 
A primeira delas refere-se à apreensão da importância da tuberculose no âmbito mundial, confrontando essas informações com o perfil epidemiológico na sociedade brasileira. A conformação das políticas públicas, em especial as elaboradas para o controle da tuberculose, será também apresentada no capítulo seguinte, além da história das representações em torno da doença ao longo dos tempos, assim constituindo a segunda vertente para a problematização do objeto. Esse encaminhamento deve proporcionar elementos que auxiliem no entendimento da institucionalização das políticas que foram sendo implementadas para o controle da doença. Essas duas primeiras vertentes possibilitam a exposição da terceira, que se refere à situação da adesão dos clientes aos programas de controle da tuberculose no âmbito mundial.

Desta forma, através da articulação dessas vertentes, busca-se entender a forma como se dá o processo de adesão dos pacientes ao PCT no Brasil, mais especificamente no Estado de São Paulo. Trata-se, portanto, de buscar analisar como a adesão ao tratamento da doença é percebida pelas pessoas que a vivenciaram, para compreender a forma como se dá esse processo, na tentativa de proporcionar elementos que iluminem a proposição de estratégias para o enfrentamento dessa questão, que se constitui num dos problemas mais complexos para o controle da tuberculose na atualidade. 


\section{Trtroduçãa}




\section{INTRODUÇÃO}

\subsection{O perfil epidemiológico da tuberculose na atualidade}

A primeira aproximação à questão da tuberculose será operacionalizada através da fotografia de sua magnitude. Há estimativas de que um terço da população mundial encontra-se infectada pelo bacilo que causa a enfermidade e que anualmente ocorrem cerca de 8 milhões de casos novos com 3 milhões de óbitos devido à doença (WORLD HEALTH ORGANIZATION, 1990; DOLIN et al., 1994). A tuberculose é a maior causa de morte por um agente infeccioso isolado, representando $25 \%$ das mortes evitáveis em adultos de países em desenvolvimento. Constitui-se ainda como a causa de morte mais comum em países com baixa renda per capita, sendo que $80 \%$ dos óbitos ocorrem em adultos de meia-idade ( MORSE, 1996). Esse quadro vem ocorrendo a despeito da implementação, na maioria dos países, de programas de controle que preconizam o uso da quimioterapia apropriada e surpreende os investigadores e técnicos da área da saúde, que há alguns anos atrás avaliavam que a doença estivesse sob controle. A curva de manifestação da doença tem se apresentado estável ou com tendência ao aumento em várias formações sociais em desenvolvimento e, atualmente, também nos países desenvolvidos, por vários motivos, destacando-se a sua associação com a Síndrome da Imunodeficiência Adquirida (AIDS). A infecção pelo HIV (Vírus da Imunodeficiência Humana) parece aumentar a suscetibilidade à infecção tuberculosa pelo debilitamento das defesas do organismo, sendo que nesses casos a infecção tuberculosa pode progredir rapidamente para doença clinicamente ativa (NUNN, et al., 1994). Do mesmo modo, doentes com tuberculose apresentam um aumento da multiplicação do HIV, provocando progressão mais rápida do quadro ocasionado por esse vírus.

Em meados de 1994, cerca de 5,6 milhões de pessoas no mundo estavam coinfectadas pelo Mycobacterium tuberculosis e pelo vírus HIV, sendo que aproximadamente $80 \%$ viviam no sub-Sahara africano. Estima-se que em decorrência da infecção por HIV, ocorra no ano 2000 um aumento da taxa de tuberculose de 13,8\% (RAVIGLIONE et al., 1995). Para se aquilatar a importância desses dados, há referência 
de que de cada dez portadores do HIV, um a três desenvolverão a doença (YÁNEZ et al., 1995).

É importante ressaltar que os países desenvolvidos apresentaram diminuição da magnitude anual, em torno de 4 a $5 \%$ ao ano, desde o início do século até a década de 40, e isso é explicado pela melhoria das condições de vida (ORGANIZAÇÃO PANAMERICANA DA SAÚDE, 1994). Com a introdução da quimioterapia, a redução do número de casos chegou a alcançar valores anuais de 10 a $13 \%$ em muitos países europeus (ORGANIZAÇÃO PANAMERICANA DA SAÚDE, 1990).

A ressurgência da doença vem colocando em pauta o desafio de revisitar os princípios técnicos, éticos e legais das medidas de saúde pública tradicionalmente utilizadas no seu controle para a obtenção de uma abordagem mais efetiva sobre a doença. Na América do Norte e, principalmente nos Estados Unidos da América (EUA), o coeficiente de incidência sofreu um aumento importante desde 1985, particularmente devido à sua associação com a AIDS, que fez emergir novas formas de apresentação da doença e de modalidades de tratamento para as quais os profissionais médicos têm mostrado progressiva carência de familiaridade, assim como da evolução de cepas resistentes a múltiplos medicamentos. Também são apontadas a deterioração das condições de vida em algumas localidades e a precariedade em termos de acesso aos serviços de saúde daqueles que são considerados como "minoridade racial e étnica" (CENTERS FOR DISEASE CONTROL, 1990; BARNES et al., 1991; BRUDNEY e DOBKIN, 1991b; CANTWELL, 1994).

Em muitos países em desenvolvimento a tuberculose é tão freqüente como era há um século atrás na Europa, apesar dos programas de controle que têm sido implementados (HOLM, 1984). Dados estimados pela Organização Mundial da Saúde (OMS) em 1990, fazem referência a 3.348.000 de casos com 1.250.000 de mortes no Sudeste Asiático; 1.740 .000 de casos com aproximadamente 800.000 mortes anuais, na África e 1.930 .000 de casos com 694.000 mortes na região oeste do Pacífico. Na região leste do Mediterrâneo havia na mesma época 696.000 casos com 276.000 mortes e nas Américas (excluindo os Estados Unidos da América - EUA - e o Canadá), 564.000 casos com 223.000 mortes. A Europa, os EUA, o Canadá, o Japão, a Austrália e a Nova 
Zelândia teriam 403.000 casos com 83.000 óbitos (WORLD HEALTH ORGANIZATION, 1993).

Na América Latina, o processo de redução da enfermidade tem sido lento e não satisfatório, não se observando decréscimo dos indices de morbidade, conforme ocorreu nos países desenvolvidos há 40 anos. Nessa região, a manifestação da doença é um claro produto das condições de vida, de trabalho, assim como da forma como as políticas de saúde têm sido estruturadas para dar conta da questão (ORGANIZAÇÃO PANAMERICANA DA SAÚDE, 1990).

Ainda que os dados de morbidade e de mortalidade mascarem subnotificações e notificações errôneas nos países em desenvolvimento, eles também se constituem em balizas que norteiam o entendimento da magnitude da tuberculose. Na maioria dos países latinoamericanos registram-se mortes e incapacidades pela enfermidade, particularmente em crianças e em adultos jovens, com variação nas taxas entre 0 e 10 por 100.000 em crianças e em adolescentes. Nos grupos mais vulneráveis, como o de recém-nascidos e idosos, a taxa de mortalidade pode alcançar ou superar os valores de 100 por 100.000 , como acontece na Bolívia, no Equador e em Honduras. É interessante verificar, no entanto, que esse perfil é marcadamente distinto no Canadá, em Cuba e nos EUA, onde a mortalidade é mais expressiva no grupo de pessoas com 45 anos ou mais (ORGANIZAÇÃO PANAMERICANA DA SAÚDE, 1990). JOHNSTON e WILDRICK, em publicação datada de 1974, já explicavam essas distinções destacando a sua ocorrência principalmente devido ao padrão diferenciado em termos de qualidade de vida das pessoas, do isolamento a que eram submetidos os doentes, além do uso efetivo da quimioterapia.

Uma vez que é bastante alta a prevalência da doença nos grupos etários que concentram a população economicamente ativa nos países em desenvolvimento, existe uma tendência em considerar esse grupo como uma das prioridades de intervenção em nivel mundial, embora sejam escassos os estudos sobre as conseqüências da tuberculose nesse estrato populacional e sobre as repercussões do acometimento deste grupo na estrutura social e econômica (MURRAY et al., 1990; WORLD HEALTH ORGANIZATION, 1990). 
Ainda buscando compreender a magnitude da doença é possível verificar que as diferenças regionais também são expressivas entre os paises das Américas. Em 1992, a incidência de tuberculose pulmonar, em casos confirmados por baciloscopia foi aproximadamente de 5 por 100.000 habitantes em Cuba e Costa Rica; ao redor de 20 nas Bahamas e Venezuela; 30 na Argentina e Uruguai; em torno de 26 no Brasil e Panamá e, conforme anteriormente mencionado, mais de 100 na Bolívia e Peru (ORGANIZAÇÃO PANAMERICANA DA SAÚDE, 1994).

O modelo de desenvolvimento econômico e social adotado pelos países cujo modo de produção privilegia de forma desigual as potencialidades de acesso ao consumo para os diferentes grupos sociais determina distinções em termos de indicadores de morbi-mortalidade inclusive no interior de um mesmo país. A dependência política, econômica, a exploração comercial e financeira que coexistem nas relações entre os países, ditos por BETTELHEIM (1976) como desenvolvidos e em desenvolvimento, reproduzem-se no interior destes últimos, expressando-se em perfis de consumo também diferenciados em suas várias regiões. Veja-se, por exemplo que no Estado de São Paulo foram registrados em 1993 cerca de 18.289 casos novos da doença, o que significa um coeficiente de incidência de 56,0, considerando-se todas as formas da doença. Em 1994 a incidência foi de 56,7, em 1995 de 56,5 (CENTRO DE VIGILÂNCIA EPIDEMIOLÓGICA, 1995) e dados provisórios de 1996, ainda não publicados, revelam um coeficiente de incidência de 55,0. Segundo levantamento realizado junto à Prefeitura do Município de São Paulo, de julho de 1990 a junho de 1992, dentre todas as doenças infecto-parasitárias, a tuberculose foi a que apresentou maior aumento do número de óbitos: 9,1\% (SÃO PAULO, 1993). Já no Piauí, a incidência da doença na mesma época foi de 67,9; enquanto que em Santa Catarina este coeficiente foi de 27,8 (CENTRO NACIONAL DE EPIDEMIOLOGIA, 1993). Através da observação de séries históricas que evidenciam a incidência da tuberculose ao longo dos anos, o que se identifica é apenas uma leve redução dos casos em cada um desses Estados, apesar dos esforços empreendidos na busca de casos, sendo que no Estado de São Paulo houve um ligeiro aumento, considerando-se o ano de 1993 até 1994 (MINISTÉRIO DA SAÚDE, 1988a; CENTRO NACIONAL DE EPIDEMIOLOGIA, 1992). 
Várias têm sido as interpretações sobre a manutenção e em alguns casos o aumento da incidência da tuberculose e uma das que têm ocupado bastante espaço na literatura refere-se à questão da adesão dos doentes aos programas de controle. Tenta-se assim justificar as taxas relacionadas à doença a partir de argumentos que têm se centrado ora no plano individual, ou seja, do doente como responsável único pelo seu processo de tratamento, ou em argumentos relacionados às deficiências institucionais, basicamente no que se relaciona aos trabalhadores de saúde.

O imaginário dos doentes com tuberculose pulmonar, a forma como a doença é por eles percebida, os modos de enfrentamento individual do processo saúde-doença podem propiciar certas condições que resultariam na adesão ou no abandono do tratamento. Nesse sentido, e por considerar que a realidade da tuberculose hoje é o produto de uma determinada forma de olhar a doença através dos tempos e da forma como foram sendo concebidas e implementadas as políticas públicas de controle da enfermidade, continuar-se-á a delimitação do problema, recuperando as raízes históricas da doença até a atualidade, apontando as várias representações que emergiram nas sociedades a respeito do agravo.

\subsection{A Tuberculose na História da Humanidade}

As micobactérias são organismos extremamente antigos que muito provavelmente já existiam muitos milhões de anos antes do surgimento dos primatas. $O$ Mycobacterium bovis, ou uma variante, provavelmente infectou animais no periodo paleolítico. Os humanos não eram seu hospedeiro natural e as primeiras infecções humanas foram quase certamente eventos isolados, resultantes da ingestão de carne ou de leite infectados. Havia pequena possibilidade da disseminação da doença nas comunidades humanas primitivas, devido à dispersão da população e ao mínimo envolvimento pulmonar. A agricultura, que teve início por volta de 7.000 anos antes de Cristo (a.C.), propiciou o surgimento de vilas e a domesticação de animais, sendo prática comum manter animais no pavimento inferior das moradias para o aquecimento das pessoas. Essas condições começaram a favorecer a disseminação aérea da infecção entre 
os seres humanos, mas a tuberculose não foi um problema de importância nas populações pré-históricas (STEAD e BATES, 1996).

HAAS e HAAS (1996), ao procederem a uma rica recuperação histórica da tuberculose, descrevem que a doença podia ser encontrada na época paleolítica, em virtude das características estruturais da conformação dos grupos de caça e de coleta, os quais se constituíam como povos nômades e dispersos, o que dificultaria a disseminação do agente etiológico. Entretanto, a maior concentração dos seres humanos no Neolítico, começou a propiciar a difusão da tuberculose.

A espondilite tuberculosa foi documentada em múmias egípcias datadas de 3.700 a.C., muito provavelmente causada pelo $M$. bovis. No entanto, como a espécie humana não é a hospedeira natural do $M$. bovis, a doença provavelmente apresentava menor virulência quando comparada ao $M$. tuberculosis (STEAD e BATES, 1996).

Relatos da disseminação da tuberculose podem ser encontrados em textos gregos e hindus, sendo que os primeiros a denominavam por "tisis" (que significa debilitamento, desgaste), cabendo a esses povos a descrição mais apurada da doença. Os textos atribuídos à Hipócrates são assinalados como constituintes do melhor repertório de informações sobre o tema, pois este pensador deslocou a interpretação da enfermidade do domínio exclusivo dos princípios religiosos, estabelecendo os fundamentos do raciocínio clínico sobre a doença, basicamente pelos seguintes sinais: tosse, expectoração, hemoptise e debilitamento (BERTOLLI FILHO, 1993, HAAS e HAAS, 1996).

Hipócrates estudou o aniquilamento progressivo que a doença causa no organismo. Ele descreveu o desenvolvimento da doença, além do tratamento utilizado na época, que consistia basicamente da ingestão de mostarda, lentilhas, leite de vaca e de cabra, adicionando água, mel ou orégano. Como alimentos sólidos recomendava carne de carneiro cozida e pescados, sendo que os alimentos gordurosos e salgados eram tido como os preferidos. Acrescia ainda o uso de vinho tinto. Galeno, partindo das observações de Hipócrates, foi um dos pioneiros na recomendação do regime climático para os doentes (MONTENEGRO, 1949). 
Do exposto anteriormente, pode-se compartilhar das afirmações de HAWES (1931) de que a história da tuberculose acompanha a história da própria civilização. Tanto é assim que há indícios da doença em dobras de papiros, além de existirem estrofes de poemas sacros hindus que, segundo MONTENEGRO (1949), “(...) conservam sua lembrança mórbida". O mesmo autor ressalta que o código de Hamurabi, 20 séculos antes de Cristo, já a registrava, sendo que tudo indica que o mundo bíblico já a conhecia.

O M. tuberculosis, provavelmente um mutante do $M$. bovis, somente se espalhou pela Europa e Oriente Médio há aproximadamente 400 anos e, gradualmente, tornou-se causa de doença esporádica na coletividade. Nesse período, a doença provavelmente apresentava rápida evolução, pequeno envolvimento pulmonar e alta letalidade. Por volta do ano de 1600, o adensamento populacional urbano e a disseminação da pobreza na Europa feudal determinaram o surgimento de extensas epidemias que caracterizaram a "grande peste branca", assim denominada para diferenciá-la da "peste negra" (peste bubônica) ou, porque inicialmente atingiu somente os europeus (STEAD e BATES, 1996).

No Novo Mundo, bacilos álcool-ácido resistentes foram encontrados nos pulmões de uma múmia, datada do ano 700, no sudeste do Peru. Entretanto, a tuberculose não era comum nas comunidades indígenas até a chegada dos europeus (STEAD e BATES, 1996).

GRIGG (1958), BATES (1992) e RYAN (1992) recuperam com bastante propriedade a forma como a tuberculose era vista por algumas sociedades e grupos sociais e BARREIRA (1992) e BERTOLLI FILHO (1993) fazem o mesmo em relação ao Brasil. Os autores apontam que, ao lado de representações que concebiam a doença como um resultado de punições divinas aos "infratores religiosos e aos ímpios", coexistiam representações que concebiam que a moléstia abatia os "puros de alma". Essas concepções assentavam-se nos pressupostos da fragilidade da carne e na necessidade de aperfeiçoamento da existência espiritual. A idéia do contágio pelos "espíritos do mal" tem suas raízes no animismo primitivo e de concepções da doença 
como oriunda de causa extrínseca ao homem, devidas à fenômenos de ordem exclusivamente naturalizada.

Utilizada na literatura pelos escritores românticos como um recurso conveniente para negar o mundo concreto e ao mesmo tempo "confessar o desencanto pela vida social", a enfermidade foi tomada como um elemento exaltador dos dotes de larga parcela da elite intelectual e era assumida como comprovação da sensibilidade e da genialidade que supostamente orientavam a existência dos indivíduos românticos (BARREIRA, 1992).

Outras concepções como a comntiana, apontavam que a doença acometia as pessoas que se colocavam contrárias às regras do "bom" funcionamento social. Nesse sentido, é importante observar que o positivismo buscava conferir validade científica ao princípio de que as moléstias acometiam aqueles que reagiam contra a ordem social, aproximando as doenças físicas e psíquicas do conjunto de "patologias sociais" que colocavam em risco a sociedade urbano-industrial (BATES, 1992).

Após a Revolução Francesa, com o emergir dos novos posicionamentos sociais e sanitários, a doença passou a ser reconhecida como própria da população pobre e marginalizada. A partir de então, a tuberculose passou a ser associada à miséria que dizimava o lumpemproletariado e os trabalhadores industriais. Nesse momento, os higienistas passaram a compor estratégias de intervenção sobre o cotidiano do coletivo sem no entanto abandonar os pressupostos fantasiosos que pairavam ainda sobre $o$ comportamento dos doentes (BATES, 1992).

A partir da aplicação dos princípios cartesianos no campo do saber médico, o organismo humano passou a ser concebido como um conjunto articulado de mecanismos e, nas últimas décadas do século XVIII, a constituição do saber clínico permitiu a afirmação de um olhar inovador sobre a doença e os doentes. Segundo FOUCAULT (1977) esse novo olhar modificou os rumos dos projetos de intervenção clínica que passaram a se orientar pela espacialização das enfermidades, quando a pergunta "o que você sente?", foi substituída por "onde dói?". 
A identificação do agente etiológico, o Mycobacterium tuberculosis, por Robert Koch, em 1882, determinou à higiene pública a análise da tuberculose como uma moléstia que poderia ser controlada através do bloqueio das fontes produtoras do material contaminante. Com isso, ganharam consistência as regras sanitárias que preconizavam a desinfecção dos objetos pessoais e do catarro dos doentes, fato que se desdobrou na ostensiva vigilância das pessoas, reforçando a doutrina militar que embasava a polícia médica da época (ROSEN, 1979). É bem verdade que a realização dessas práticas, constitui-se em um produto da forma como as sociedades se organizavam naquele momento, bem como do estágio em que se encontrava o saber sobre a doença.

As pesquisas que se sucederam ampliaram ainda mais o conhecimento fisiopatológico sobre a moléstia que, desde o encerramento do século passado, ganhou a denominação oficial de tuberculose, após ter sido chamada desde tempos muito antigos, conforme anteriormente mencionado, por "consunção", "peste branca" e "tísica", dentre outras designações (BERTOLLI FILHO, 1993).

Paralelamente ao aprimoramento do saber sobre a patogenia da enfermidade, no decorrer da história, pesquisadores têm desdobrado esforços para a obtenção de terapias eficientes na cura e na prevenção da tuberculose. Mas a impotência dos primeiros medicamentos para o tratamento dos doentes impôs como solução paliativa, durante largo período de tempo, o uso clínico do regime dietético, do descanso e da climatoterapia. Em meados do século XIX, a medicina germânica tornou-se a propulsora do movimento que atestava serem as regiões montanhosas e de clima frio o ambiente ideal para o tratamento dos infectados, inaugurando a era sanatorial de isolamento dos doentes. No início do século XX, a Medicina, alicerçada no método experimental de Claude Bernard, bem como na teoria microbiana de Louis Pasteur, e na descoberta do bacilo por Koch, propôs novas explicações sobre a tuberculose e seu mecanismo de infecção (RYAN, 1992).

Segundo POZSIK (1993) antes da introdução da quimioterapia contra a enfermidade, tanto o médico como o doente tinham pouco controle dos resultados do tratamento contra a enfermidade. "O doente podia seguir o tratamento que consistia de 
descanso, alimentação nutritiva, ar fresco, mas ainda para $50 \%$ dos casos, a morte era inevitável".

Em 1908, Albert Calmette e Camille Guérin, ao cultivar tubérculos bovinos em culturas detectaram a diminuição da virulência do bacilo. Assim, esse produto, que veio a constituir a vacina BCG, foi pela primeira vez utilizado para imunizar uma criança cuja mãe havia morrido por tuberculose (RYAN, 1992).

No final da Segunda Grande Guerra começou a ser empregada a primeira droga específica para o tratamento da tuberculose, a estreptomicina, que mudou drasticamente o quadro de mortalidade nos vários países, inclusive no Brasil, sem que no entanto, houvesse uma diminuição significativa das taxas de morbidade (CORPE, 1972; ISEMAN e MADSEN, 1989; BARREIRA, 1992; RYAN, 1992). O ano de 1947 marcou o início da chamada "era da quimioterapia". A isoniazida entrou em cena como uma droga efetiva contra a doença em 1952 (PREZ e HEIM, 1990). Nos primeiros anos o emprego dos medicamentos causou um certo furor otimista para a humanidade, pois se vislumbrava o "desaparecimento" da enfermidade. Além disso, o advento da terapia oral colocou em tela a discussão relativa às vantagens do tratamento no âmbito domiciliar, diminuindo a ocupação dos sanatórios (BRAUSCH e BASS, 1993).

A partir de 1956 ficou demonstrado que a ingestão regular dos medicamentos combinados durante um certo período de tempo constituía a condição fundamental para a cura. A introdução da rifampicina nas possibilidades terapêuticas ocorreu somente em 1966 (BRAUSCH e BASS, 1993), sendo que isso respaldou, em nível mundial, a política de controle da doença, que indicava como princípio básico a estratégia de expansão da cobertura do tratamento sobre a população atingida (WORLD HEALTH ORGANIZATION, 1990). O esquema de tratamento de seis meses foi internacionalmente reconhecido como eficaz no final da década de 70 , sendo que na época, a tuberculose foi considerada como um problema solucionado (GERHARDT e RIBEIRO, 1995). Não se deve omitir, no entanto, o fato de que a própria Organização Mundial da Saúde não considerou, nessa ocasião, a necessidade do diagnóstico oportuno, além de não enfatizar a necessidade da regularidade do tratamento, elementos fundamentais na geração de impacto epidemiológico sobre a doença. 
Estudos epidemiológicos evidenciam que a quimioterapia da tuberculose bacilífera se constitui em uma das intervenções de saúde mais "custo-efetivas", uma vez que o gasto aplicado no tratamento é superado pela ruptura da cadeia epidemiológica a partir da instituição do tratamento (WORLD HEALTH ORGANIZATION, 1992; WORLD BANK, 1993; PORTER e McDAM, 1994), sendo que HOLM (1984) menciona que, na ausência de tratamento, 50 a $60 \%$ das pessoas com tuberculose pulmonar tem risco potencial de morrer. Ao buscar analisar mais amplamente a questão, o autor enfatiza um aspecto de extrema importância, qual seja o de que o problema da tuberculose não reside apenas nas medidas de combate, mas também na forma como os serviços de saúde as empregam: “... raras vezes se observa uma participação comunitária organizada...", advogando que a comunidade deve estar envolvida na contenção dos casos.

Segundo WILKINSON (1994) a busca de casos e o tratamento constituem o único método que pode impactar a curto prazo na transmissão da tuberculose, uma vez que o autor considera que as condições sócio-econômicas constituem uma solução a longo prazo. Ao ponderar que tanto a falência do tratamento como também as recidivas são elevadas na ausência de supervisão do tratamento, aponta para a necessidade da realização de investigações com a finalidade de se diminuir as altas taxas de abandono.

Ora, como colocado anteriormente, a introdução da quimioterapia proporcionou novas perspectivas sobre o perfil de mortalidade. Entretanto, os indicadores apontavam, no final da década de 80 , o recrudescimento da enfermidade, o que determinou à OMS declarar a tuberculose como doença a ser combatida com urgência no mundo (MINISTÉRIO DA SAÚDE, 1994a).

Dentro desse contexto foram recomendadas mundialmente como medidas para a transformação dessa situação, a busca de casos bacilíferos e o tratamento adequado dos casos, já instituídas no Brasil desde a década de 70 (MINISTÉRIO DA SAÚDE,1994b). Assim veja-se a seguir a forma como as políticas públicas para o controle da tuberculose foram sendo implementadas no país. 


\subsection{As Políticas de Controle da Tuberculose no Brasil}

Utilizando como referência mais uma vez os trabalhos de BERTOLLI FILHO (1993) e de BARREIRA (1992), pode-se verificar que no Brasil, de modo geral, os documentos que registram a história da tuberculose e do tuberculoso relatam as experiências individuais $\mathrm{e}$ as reações coletivas frente à doença, além das medidas preconizadas pelos serviços de saúde pública aos modelos higienistas internacionais. No período imperial a Saúde Pública se constituiu em um dos principais setores sobre o qual a administração governamental deveria intervir, já que o padrão sanitário predominante depunha contra a qualidade da "raça brasileira". A definição do Brasil como um vasto hospital, onde a tuberculose era uma das principais protagonistas, exigia a imediata intervenção sanitária (BERTOLLI FILHO, 1993).

Entretanto, notam-se no decurso da história, flutuações no que se refere às intervenções do Estado no controle da tuberculose. $\mathrm{O}$ resultado do seu afastamento junto aos compromissos que buscavam garantir a qualidade da Saúde Pública nacional pode ser notado na precariedade do combate à enfermidade (BARREIRA, 1992).

As ações direcionadas para a institucionalização do controle da doença deram-se paralelamente à redefinição do moderno Estado Nacional e ao processo de formação da sociedade de classes. As preocupações nacionais com a tuberculose tomaram impulso a partir do final do século passado, no momento em que o país buscava marcar seu espaço no contexto internacional. Como um fenômeno fundamentalmente urbano, eram buscadas soluções que foram engendradas segundo os interesses das elites concentradas nas capitais, em particular em São Paulo e no Rio de Janeiro. Assim, grupos organizados de caráter filantrópico mobilizaram-se nessa época para combater a doença, sendo que especialistas se integraram para fundar as Ligas Contra a Tuberculose, sob a mística da "guerra santa" (BARREIRA, 1992).

Dessa forma, ao deixar de contar com a atenção e os recursos oficiais, a sociedade civil assumiu as tarefas de criação e de patrocínio das instituições que tinham o objetivo de prevenir o contágio e amparar os tuberculosos pobres. Destaca-se, nesse sentido, a Associação Paulista de Sanatórios Populares para Tuberculosos, 
posteriormente denominada Liga Paulista Contra a Tuberculose que, a despeito de todas as dificuldades de sobrevivência, durante a República Velha serviu como um marco na inspiração das demais campanhas estaduais. Gradativamente foram constituídos grupos desse tipo visando o controle da doença no interior dos demais estados do país, mas é bem verdade que esse tipo de intervenção em parte respondia aos interesses das classes detentoras do poder, sendo que efetivamente pouco era modificado em termos das condições sociais que contribuiam para a manutenção da doença. Em geral essas Ligas trabalhavam sob o princípio da necessidade do "socorro aos despossuídos", sendo que as mulheres tiveram papel fundamental na organização de eventos para a consecução de recursos financeiros (BARREIRA, 1992). Esse movimento filantrópico, baseado fundamentalmente no humanitarismo, promoveu o Congresso das Sociedades Beneficentes da Luta Anti-Tuberculose que reuniu desde profissionais da saúde, até representantes do setor bancário, do comércio, da indústria e do campo artístico (RIBEIRO, 1956).

A Associação Sanatórios Populares de Campos do Jordão, no Estado de São Paulo, órgão de cunho beneficente, constitui-se um marco na história da tuberculose e foi inspirada no modelo europeu, particularmente no sanatório popular situado na estação climática de Leysin, na Suíça (BERTOLLI FILHO, 1993).

Com a Divisão Nacional de Saúde em 1941, foi criado o Serviço Nacional de Tuberculose, que tinha como elementos básicos que norteavam o desenvolvimento de seu trabalho, a potencialidade do contágio através dos doentes e pelas pessoas "aparentemente" sadias, além da necessidade da deteç̧ão precoce e isolamento dos casos.

No Pós-Guerra, com a intensificação da penetração econômica norte-americana que ao mesmo tempo determinou marcada influência política, científica e cultural para o país, foi criada a Campanha Nacional de Controle da Tuberculose. Acima de tudo ela refletia uma possibilidade de maior intervenção do Estado nas políticas sociais. A Campanha assumiu, segundo BARREIRA (1992), um caráter de "cruzada", ao se desenvolver em um clima de exaltação patriótica e de modernização da administração sanitária. Com isto, a enfermidade passou a ser incluída no programa de governo, 
ocorrendo uma crescente normatização e padronização dos serviços que atendiam os doentes. Data dessa época o uso da abreugrafia para a detecção dos casos.

Com a ampliação das funções do Estado e o uso das estratégias da corrente do Planejamento durante o governo do Presidente Juscelino Kubitschek, a Campanha Nacional de Controle da Tuberculose sofreu a mesma tendência que outros programas em termos de crescente planificação. Com a implantação do regime militar, emergiu o discurso da racionalidade, da eficácia e do saneamento financeiro. Tal discurso teria apresentado resultados positivos se estivesse sustentado pela ideologia da transformação da qualidade dos serviços de saúde, o que revelaria um novo cenário na Saúde Pública brasileira (BARREIRA, 1992). No entanto, a reforma administrativa que se seguiu estabeleceu um padrão que passou a privilegiar a medicina previdenciária, individual e assistencialista, em detrimento das ações de Saúde Pública, que ficavam sob a responsabilidade do Ministério da Saúde. A restrição de recursos imposta ao Ministério refletiu na diminuição de gastos com a tuberculose.

No Estado de São Paulo, o Planejamento em Saúde foi concretizado pelo modelo da Programação em Saúde, fruto do processo de reforma administrativa que tinha como pano de fundo a visão fayolista. Nessa reforma buscou-se a ordenação de uma dinâmica institucional centrada na capacidade de intervenção sobre os danos. Assim, foram propostos como instrumentos principais aqueles projetados tecnologicamente pela corrente médico-sanitária do campo da saúde pública, conforme os princípios da história natural da doença (MERHY, 1995).

As mudanças políticas e econômicas que ocorreram a partir da década de 70 fortaleceram o processo de Reforma Sanitária, assentado nos pressupostos de integração, hierarquização, regionalização dos serviços de saúde e participação da comunidade, tendo em vista a transformação da estrutura do sistema de saúde brasileiro que culminou com a incorporação do Sistema Único de Saúde (SUS) na Constituição de 1988 (BRASIL, 1992). A integração dos antigos Dispensários de Tuberculose aos centros de saúde, ao lado da progressiva integração do Programa de Controle da Tuberculose às unidades de saúde resultou, segundo ARANTES et al. (1995), na bem sucedida desconcentração do atendimento. 
Nessa época, o Programa de Controle da Tuberculose, segundo HIJJAR (1993), já tinha logrado um certo grau de organização, desenvolvendo esforços para centralizar as ações nos serviços públicos de saúde e atingindo mais de $90 \%$ dos municípios brasileiros com atividades de diagnóstico e tratamento. Segundo o autor, observou-se na ocasião, significativa redução na mortalidade, queda “... ainda que pequena na incidência, cobertura vacinal elevada com BCG na maioria das unidades federadas e utilização de esquema encurtado eficaz, há mais de 10 anos, com pirazinamida, rifampicina e isoniazida ...".

No entanto, parece que esse processo não tem dado conta de mudar a problemática no que toca a assistência à doença, principalmente em decorrência da deterioração progressiva do sistema de saúde em decorrência da opção pelo modelo econômico substantivamente orientado pelo ideário do neoliberalismo (SMITH e OLIVEIRA, 1995), como também devido às demandas que se estabeleceram pelo embate entre esse processo e a implementação da municipalização. Na realidade, o que se pode verificar é que o SUS sofreu uma série de rupturas na sua implementação, como a precária destinação de recursos ao setor, dentre outras, evidenciando que as mudanças ocorridas na macroestrutura repercutiram agudamente sobre o campo da saúde. Assim, apesar do aumento do número de unidades integradas ao Programa de Controle da Tuberculose, além da possibilidade da realização do diagnóstico e tratamento dos doentes em locais mais próximos dos seus domicílios, em virtude da regionalização e da hierarquização, houve uma tendência para que se privilegiassem ações de prontoatendimento, o que levou, junto com outros problemas, à perda da qualidade nas ações programáticas. Observou-se um retrocesso em relação ao que havia sido construído anteriormente, no que se refere à diminuição da busca de casos entre sintomáticos respiratórios e os comunicantes de casos de tuberculose, além do aumento do abandono do tratamento, especialmente nos grandes centros urbanos e nas periferias. Ao lado disso começou a ocorrer falta de medicamentos que, segundo HIJJAR (1993) só foi equacionada no final do ano de 1992. Veja-se que, em função desse processo, o atendimento programático que foi mantido até o final da década de 70 , começou a sofrer solução de continuidade, resultando na perda da capacidade resolutiva do Programa como um conjunto de ações normatizadas e sistematizadas para o controle da doença. 
O Programa de Controle da Tuberculose, que vem sendo operacionalizado atualmente, preconiza que o controle da doença deve se assentar na proteção aos sadios, através da vacina BCG, da procura e diagnóstico de casos e no controle de comunicantes, além do tratamento dos doentes com isoniazida, rifampicina $\mathrm{e}$ pirazinamida ou outras drogas como a estreptomicina, o etambutol, a etionamida, a kanamicina e a cicloserina. Essas medidas são padronizadas para o país pela Fundação Nacional de Saúde do Ministério da Saúde, a quem compete a coordenação do Programa de Controle da Tuberculose como parte do Programa de Pneumologia Sanitária (MINISTÉRIO DA SAÚDE, 1994b).

A medicação deve ser ingerida diariamente e no caso dos pacientes adultos portadores de tuberculose pulmonar são utilizadas $10 \mathrm{mg} / \mathrm{kg}$ de rifampicina (RMP); 10 $\mathrm{mg} / \mathrm{kg}$ de isoniazida (INH) e $35 \mathrm{mg} / \mathrm{kg}$ de pirazinamida (PZA). Com a finalidade de se evitar o surgimento de resistência bacteriana adquirida, no início do tratamento, deve-se empregar associadamente mais de uma droga. A INH e a RMP são drogas capazes de impedir a seleção de mutantes resistentes. Em função do ciclo bio-patológico do bacilo da tuberculose, o tratamento compõe-se de duas fases, denominadas por fase de ataque e de manutenção. $\mathrm{Na}$ primeira, busca-se a redução rápida da multiplicação do bacilo pelo emprego das três drogas. Sabendo-se que uma cavidade tuberculosa com aproximadamente dois centímetros de diâmetro, na fase inicial do tratamento, pode albergar até 10 bilhões de bacilos, a associação de duas drogas, como por exemplo a isoniazida e a estreptomicina, pode destruir os mutantes geneticamente resistentes a uma delas, evitando-se a emergência da resistência adquirida. Nessa fase a PZA tem como função a destruição das bactérias no interior do macrófago. Esse esquema deve ser aplicado durante dois meses (MINISTÉRIO DA SAÚDE, 1994b).

$\mathrm{Na}$ fase seguinte, a de manutenção, o emprego das drogas tem por objetivo a destruição dos bacilos que se encontram no material caseoso. Essa etapa se estende por mais 4 meses, durante a qual são mantidas a rifampicina e a isoniazida (MINISTÉRIO DA SAÚDE, 1994b). É importante mencionar que a presença de AIDS e a história de abandono pregresso determinam a adoção de esquema distinto do anteriormente citado. 
Um outro aspecto fundamental a ser destacado é que a interrupção do seguimento da terapêutica possibilita a multiplicação dos microrganismos semilatentes, podendo causar a recidiva da enfermidade. "Os bacilos que escapam à ação das drogas podem permanecer no interior do macrófago ou do "caseum" em estado de latência ou de atividade metabólica extremamente reduzida. Esta persistência bacteriana explica a reativação de um foco tuberculoso, após o tratamento em paciente até então considerado como curado" (MINISTÉRIO DA SAÚDE, 1994b).

O Programa enfatiza que o tratamento deve ser desenvolvido em regime ambulatorial, no serviço de saúde mais próximo do domicílio do doente e a hospitalização deve ocorrer somente em casos especiais, como nos problemas sociais, nos portadores de meningite tuberculosa, nas indicações cirúrgicas, na intolerância medicamentosa incontrolável em regime ambulatorial e nas intercorrências clínicas e/ou cirúrgicas graves, ou na presença de estado grave que não permita o tratamento ambulatorial (MINISTÉRIO DA SAÚDE, 1988b).

Na década de 90, o Ministério da Saúde, em conjunto com as secretarias estaduais de saúde, definiu objetivos operacionais e epidemiológicos a serem atingidos até o fim do ano de 1994. Dentre eles, pode-se destacar: a cobertura da totalidade dos municípios, no que se refere às atividades de controle da tuberculose, $60 \%$ de integração das unidades de saúde do setor público com o programa de controle da enfermidade, $90 \%$ de cobertura vacinal com BCG em menores de um ano de idade, a cura de $85 \%$ dos casos submetidos a tratamento, a redução anual de 7,5\% da mortalidade decorrente da doença em todas as idades e redução anual de $10 \%$ da mortalidade em menores de 5 anos de idade (HIJJAR, 1993).

De fato, pode-se observar que as estratégias de intervenção estão dirigidas à prevenção e ao tratamento da enfermidade. Dentre o conjunto de alternativas para a prevenção, têm-se apontado a vacina $\mathrm{BCG}$, a busca de casos e o controle de comunicantes. A administração da vacina BCG é indicada a partir do nascimento e, seguramente, o Brasil tem apresentado boa cobertura vacinal (MINISTÉRIO DA SAÚDE, 1994a). Quanto à busca de casos e controle de comunicantes, parece não 
existir dados suficientes que garantam que essa prática tenha causado impacto no quadro endêmico.

Em relação ao plano terapêutico, as drogas são fornecidas pela rede pública de saúde e, durante vários momentos até há poucos anos atrás, não era raro que não se dispusesse de uma ou mais drogas para o uso pelos doentes.

Além disso, a prática de assistência aos pacientes com tuberculose, bem como a literatura, apontam sistematicamente para as dificuldades no processo de adesão dos pacientes ao esquema medicamentoso. Nesse sentido, abordar-se-á a seguir alguns aspectos que permitam uma visão mais global a respeito da adesão ao tratamento.

\subsection{A Questão da Adesão ao Programa de Controle da Tuberculose}

Segundo DIXON et al. (1957) a preocupação pela questão da adesão de pacientes ao tratamento de doenças revela-se principalmente a partir dos estudos realizados com hipertensos, os quais buscavam dar conta do entendimento do processo que levava os pacientes a aderir ou a abandonar a terapêutica medicamentosa.

Para SUMARTOJO (1993) a palavra que tem sido utilizada no idioma inglês para a adesão é compliance, que quer dizer subserviência, docilidade. Dado o caráter [implícito] de uma relação assimétrica que o termo coloca em evidência, a autora sugere a utilização de um outro vocábulo - adherence - que refletiria o papel ativo do doente no controle de seu próprio tratamento. No Brasil, a prática profissional tem mostrado que duas palavras têm sido utilizadas: aderência, que quer dizer "qualidade de aderente; adesão; fixação; ligação; união", e adesão, que significa "ato de aderir; aderência; assentimento; aprovação; concordância" (FERREIRA, 1986).

Outro aspecto refere-se ao conceito de adesão. A literatura coloca em evidência uma ampla variedade de conceitos, entre os quais o de HAYNES (1989), que incorpora uma série de condições ao definir adesão como: dimensão do comportamento pessoal no que se refere à tomada de medicação, seguimento das dietas ou mudança de estilos de 
vida, segundo o aconselhamento de profissionais da saúde. $O$ autor, apesar de nitidamente deixar clara a responsabilidade que teria o doente nesse processo, advoga que o termo não deve conter pré-julgamentos, distinguindo também outros fatores que podem estar envolvidos na adesão, dentre os quais:

- em relação à doença: diagnóstico, gravidade, sintomas, grau de incapacidade, duração, hospitalização prévia, permanência no hospital, melhora clínica.

- em relação à instituição: tempo de espera, esquema de tratamento, horário para consulta, tempo decorrido entre as consultas, acesso físico, necessidade de se ausentar do trabalho, problemas decorrentes do clima e transporte.

- em relação ao regime terapêutico: tipo de tratamento (oral, parenteral), duração da terapia, número de drogas, freqüência de uso, dose, efeitos colaterais, custo e disponibilidade de medicação.

Por outro lado, PORTA (1994) define a adesão a partir de uma perspectiva mais ampla, ao defendê-la como "fruto da compreensão da própria situação de saúde e qualidade da integração médico-paciente que mensura a adaptabilidade das intervenções a fatores subjetivos, históricos e ambientais".

A Organização Mundial da Saúde reconhece que a falência do controle da tuberculose reside no inadequado manejo dos instrumentos disponíveis, indicando claramente a baixa adesão dos pacientes ao tratamento como a sua principal causa, tanto nos paises desenvolvidos como nos países em desenvolvimento (FOX; 1962; ADDINGTON, 1979; KOCHI, 1991).

Há uma imensa variedade de publicações que denotam um esforço na compreensão da questão, na sua mensuração e na proposição de medidas para modificar a situação. POZSIK (1993) faz referência a dados produzidos pelo Centers for Disease Control dos EUA em 1990, os quais ressaltavam que, de modo geral, cerca de $24,2 \%$ dos pacientes residentes em localidades onde existiam programas de controle da tuberculose não completavam o regime terapêutico quando se tratava de um período de tratamento de 12 meses, indicando taxas de 55\% de abandono em algumas áreas. Ao estudar profundamente a questão do abandono do tratamento em tuberculose, faz uma série de reflexões que incluem aspectos como o fato de que há estimativas recentes que 
indicam que cerca de 40 a $50 \%$ dos pacientes não fazem uso dos medicamentos conforme a prescrição médica, até que aproximadamente $33 \%$ dos pacientes prospectivamente falhariam no seguimento das recomendações médicas.

A mesmo autora, ao fazer referência à complexidade da questão, relata que estudiosos do assunto anedoticamente estimam que o abandono do tratamento varia entre 20 a $80 \%$. Enfatiza que não há um grupo específico ou classe social que possa ser identificada como de maior risco, de modo que não há um preditor positivo de abandono. Entretanto, conforme será revelado no decorrer do presente estudo, a adesão ao tratamento está intrinsecamente articulada a alguns elementos concretos que dizem respeito tanto ao processo de adoecimento do doente e sua inserção na sociedade, como dizem respeito ao processo de produção da saúde. A terapêutica medicamentosa, mesmo sendo eficaz, sofre portanto o contraponto da singularidade do doente em correlação com sua inserção na sociedade.

Uma das principais referências sobre a questão da adesão é a obra de HAYNES et al. (1989). A partir de uma vastíssima e cuidadosa revisão de literatura, os autores reconhecem que a adesão parece não ter recebido atenção sistemática até a sua (re)descoberta pelos tisiologistas na década de 70, quando o abandono ao programa de controle de tratamento começou a se tornar uma realidade que impedia ou dificultava o controle da doença. Segundo DIXON et al. (1957), na década de 50, essa questão já era identificada como fundamental.

Não especificamente se referindo à tuberculose, mas a esquemas de tratamento utilizados por largos períodos de tempo, HAYNES (1989) afirma que a adesão a esquemas de tratamento para doenças de evolução crônica em geral é de somente $50 \%$.

Aparentemente estão bastante estabelecidas algumas condições relacionadas à não adesão aos tratamentos de modo geral, dentre elas questões relacionadas ao serviço de saúde, como o agendamento prévio, ou aquelas relativas ao tratamento especificamente, à via de inoculação e, neste caso, a via injetável promoveria maiores problemas (HAYNES, 1989). No que se refere à tuberculose, algumas características que denotam fragmentos da classe social à qual os indivíduos pertencem, têm sido arroladas como relacionadas ao abandono do tratamento, dentre elas, o sexo: sendo que 
de maneira geral, o masculino apresenta maiores índices de evasão do tratamento; a idade: abaixo de 45 anos; o estado civil: solteiros; o baixo nível de instrução; os trabalhadores eventuais; sem residência fixa; bem como os alcoolistas. Estes, ao lado daqueles que apresentam intolerância às drogas utilizadas para o tratamento da doença, são aqueles que mais têm mostrado associação estatística significativa em relação à baixa adesão (FRIEDMAN et al., 1987; FERRER, 1991; SUMARTOJO, 1993). As investigações que chegam a esse tipo de conclusão procedem a análises em que as variáveis analisadas são tomadas como atributos do ser humano, sem que sejam realizadas interpretações que busquem um olhar mais totalizante, que recupere os processos mais gerais que podem levar os doentes ao abandono do tratamento.

Alguns modelos têm sido utilizados para explicar a questão da adesão. Um deles refere-se ao "Health Belief Model", largamente utilizado nos EUA desde a década de 70, cuja teoria argumenta que a pessoa leva em conta as questões de saúde a partir de sua percepção individual sobre o nível de suscetibilidade em relação à doença ou situação particular que a acomete, segundo o grau de severidade das conseqüências do processo patológico, se orgânico ou social, dos beneficios ou eficácia que trará a prevenção da doença, bem como se relaciona às barreiras físicas, psicológicas ou financeiras. Posteriomente, o modelo original foi revisto e passou a incluir a questão relativa às motivações em saúde, ou seja, tudo o que se relaciona com as práticas e comportamentos preventivos em saúde, ao crédito do doente no profissional e cuidados médicos, além das características da relação médico-paciente as quais influiriam na adesão. A questão primordial que se coloca nesse Modelo é fazer com que a pessoa se sinta suficientemente estimulada para desenvolver um "comportamento" apropriado, fazendo com que seja consciente e responsável sobre a sua própria saúde. Essa teoria remete ao indivíduo a responsabilidade sobre a sua própria saúde e, embora assuma que fatores sócio-demográficos e estruturais podem influenciar o comportamento em saúde, essas variáveis não são visualizadas como diretamente causadoras da adesão (BECKER et al., 1989).

Evidentemente que essa teoria pode ser utilizada para explicar os comportamentos e atitudes das pessoas perante a doença, mas uma de suas limitações é justamente quando remete ao nível do individual toda a responsabilidade sobre a saúde. 
Assumindo que a saúde é um conceito amplo e que está diretamente relacionado às questões de ordem "pessoal", mas também diretamente relacionada às questões estruturais que sem dúvida se interrelacionam e determinam um certo padrão de comportamento e de vida e, portanto, de saúde-doença, há que visualizar a questão da adesão não somente a partir da ótica comportamentalista, mas como sobredeterminada por outras dimensões que exercem um importante papel nas manifestações da doença ou no modo de andar a vida. Uma outra limitação do Modelo refere-se ao fato de que contempla, na relação com o paciente, somente o polo relativo ao saber médico, deixando de lado a fundamental atuação dos demais profissionais da saúde, além da vivência do próprio doente.

Uma outra restrição desse Modelo refere-se à determinação de taxar as pessoas, para fins administrativos, como aderentes/não aderentes, não levando em conta o fato de que em um processo longo como o é o tratamento realizado por um período de seis meses, há momentos de adesão/não adesão e que não são considerados quando se trata de proceder a um diagnóstico sobre a situação real do paciente.

No que se refere à questão específica do tratamento contra a tuberculose, há dados que confirmam que a tuberculose é curável em $100 \%$ dos casos, quando se considera especificamente a eficácia do uso dos medicamentos (MINISTÉRIO DA SAÚDE, 1988b).

Mas, segundo a OMS (WORLD HEALTH ORGANIZATION, 1990), a despeito da disponibilidade de drogas altamente poderosas e efetivas, os programas de controle da doença de países em desenvolvimento têm apresentado somente $50 \%$ de taxa de cura. RUBEL e GARRO (1992), ao afirmarem que a falta de adesão é uma das principais barreiras para o sucesso do controle da tuberculose, afirmam que em muitas nações, menos da metade dos doentes recebem diagnóstico e, daqueles que iniciam o tratamento, menos de $50 \%$ chegam ao seu final. Este dado é de fundamental importância, uma vez que os casos não tratados constituem fontes bacilíferas com alto poder de transmissibilidade, sendo que os pacientes que abandonam o Programa de Controle têm um papel fundamental no aumento da resistência das cepas do Mycobacterium tuberculosis e na disseminação da doença (BAYER, 1993; CENTERS FOR DISEASE 
CONTROL, 1993a). Além disso, a não adesão ao tratamento pode provocar mudanças genéticas no Mycobacterium tuberculosis o que pode levar a sérias limitações no controle da doença (WEIS et al., 1994).

No Brasil, o abandono do tratamento é considerado quando o doente deixou de comparecer ao serviço de saúde por mais de 30 dias consecutivos, após a data aprazada para o seu retorno (MINISTÉRIO DA SAÚDE, 1988b). Ou seja, diz respeito a pessoas consideradas pelo serviço de saúde como casos "encerrados", sem que efetivamente o tratamento tenha sido desenvolvido com sucesso. Em 1987, a taxa de abandono no país esteve em torno de 15\% (MINISTÉRIO DA SAÚDE, 1988a). Frente às taxas de resultado de tratamento em avaliações de coortes estaduais e nacionais do Programa de Controle da Tuberculose entre 1981 a 1990, ao serem considerados 100 doentes, concebia-se uma taxa de cura de 79,3\% e uma taxa de abandono de 13,3\% (MINISTÉRIO DA SAÚDE, 1992). No que se refere ao Estado de São Paulo, a análise dos resultados do tratamento no sétimo mês, período em que a maioria dos pacientes deve ter alta por cura, evidencia que o Estado ainda apresenta alto índice de abandono do tratamento, cerca de $18 \%$ (SÃO PAULO, 1993).

A literatura confirma que a porcentagem de cura está articulada ao seguimento do tratamento e a outros elementos inerentes a esse processo. Nesse sentido, quais são as tendências da produção de conhecimentos sobre a questão?

É fundamental colocar que, durante o processo de revisão bibliográfica, foram escassas as produções de caráter nacional em relação à essa temática, em contraposição à imensa variedade de publicações do exterior. No âmbito nacional foram encontrados estudos que avaliam a adesão ao tratamento, a partir da introdução do esquema de curta duração, de 6 meses. Com relação a esse esquema, BELLUOMINI e TAGUSAWA (1984), ao analisarem prontuários de 308 doentes matriculados em unidades sanitárias do Vale do Paraíba, encontraram uma taxa de abandono de $6,8 \%$. No percurso do trabalho, as autoras não analisaram as causas desse abandono. Outros poucos estudos fazem referência à avaliação da interferência de alguns fatores que influenciariam a adesão, conforme será verificado posteriomente (DEHENZELEIN et al., 1996; COSTA et al., 1997; OLIVEIRA, 1997; SHIRASSU et al., 1997). 
$\mathrm{Da}$ revisão bibliográfica no espaço internacional, alguns estudos foram selecionados e aqui se encontra o relato de algumas questões mais nucleares referentes ao objeto de estudo. Antes de iniciar esse percurso, há que lembrar que as investigações apresentadas têm como referência processos sociais distintos e, portanto, apresentam diferentes experiências, que não devem ser compreendidas sem o cuidado de visualizar essas especificidades. É temeroso assumir, nesse sentido, a comparabilidade entre os estudos, já que as características são diferentes quanto aos determinantes dos processos. Assim, a análise inferencial é eminentemente equivocada.

Além disso, devido à vasta gama de publicações que evidenciam a preocupação pela temática da adesão dos pacientes ao tratamento, os dois tópicos a seguir foram destacados do conjunto desta Introdução, pois revelam essencialmente as formas pelas quais os diversos autores têm concluído sobre as causas que levam ao abandono da terapêutica. De um lado, imputam essa responsabilidade unicamente ao doente ou, outras vezes, apontam esse fracasso devido às falhas do Programa de Controle da Tuberculose.

\subsubsection{O Fracasso do Programa de Controle da Tuberculose: quando a responsabilidade é imputada ao doente}

A Organização Mundial da Saúde (WORLD HEALTH ORGANIZATION, 1990), o Ministério da Saúde do Brasil, através do Programa de Controle da Tuberculose (MINISTÉRIO DA SAÚDE, 1988b), além de dados da Secretaria de Saúde do Estado de São Paulo (SÃO PAULO, s/d), bem como vários autores da literatura internacional, como TOMAN (1980), CHAULET (1990/1991) e MURRAY et al. (1990), dentre outros, identificam a atitude dos pacientes por não tomar a medicação com regularidade, além da interrupção do tratamento, como as causas básicas do insucesso dos programas de controle da doença.

RUBEL e GARRO (1992) arrolam as seguintes condições que interferem no sucesso dos programas: o desconhecimento sobre os sintomas da enfermidade, os custos do transporte para dirigir-se aos serviços de saúde, além do custo da medicação e do estigma social. Esses autores denominam tais condições como "fatores sócio-culturais", 
próprios do cotidiano das pessoas, salientando que não têm sido suficientemente explorados e que os profissionais de saúde deveriam buscar se aproximar da problemática da "cultura sobre saúde" própria do vivenciar o processo saúde-doença. Advogam que a compreensão dessas questões diminuiria o processo de abandono do tratamento.

No Brasil, mais especificamente em Pelotas, no Rio Grande do Sul, verificou-se que o abandono ao Programa de Controle da Tuberculose no período de 1994 a 1995 foi de $20 \%$, sendo que não se encontrou significância estatística para idade, sexo, presença de sintomas e para fatores sócio-econômicos, como trabalho do chefe da familia e alcoolismo (COSTA et al., 1997). Na verdade, os autores indicam que a cor não branca é o único fator de risco estatisticamente associado, chamando a atenção para o fato de que isso provavelmente ocorreu devido ao tamanho da amostra estudada (154 casos novos).

Taxa semelhante de abandono, $17,6 \%$, foi encontrada no estudo realizado junto a pacientes tuberculosos matriculados no Hospital do Servidor Público Estadual, em São Paulo, no periodo de 1993 a 1995, sendo que não foram encontradas associações estatisticamente significativas em relação ao sexo, idade, forma clínica, tratamento prévio, substituição das drogas do esquema tríplice, alcoolismo, AIDS e diabetes, sugerindo os autores que devem existir outras condições que influenciam preponderantemente a não adesão ao tratamento (SHIRASSU et al., 1997).

DEHEINZELIN et al. (1996), buscando identificar os doentes com alto risco de abandono a partir de dados obtidos durante a primeira consulta médica, realizaram estudo prospectivo com 257 pessoas, avaliadas por três anos consecutivos no Ambulatório de Tuberculose do Hospital das Clinicas da Faculdade de Medicina da Universidade de São Paulo. A taxa de abandono foi de 33,9\%, sendo que encontraram a prevalência de alcoolismo e de comportamento de risco para infecção por HIV, além da forma de apresentação extrapulmonar como relacionadas ao abandono. Os autores explicam a relação linear, de causa-efeito, do consumo de álcool e drogadição no que se refere ao abandono com base na interpretação de que o seu uso promove um estado de 
euforia que resultaria na desorganização de pensamentos e conseqüente distorção da definição de prioridades na vida.

Ainda buscando encontrar condições que estariam relacionadas ao abandono do tratamento, foi realizado um estudo na cidade de Campinas-SP entre 1993 a 1994, conforme o qual foi constatado que $56,5 \%$ dos abandonos ocorriam em indivíduos que não estudaram ou tinham apenas o antigo curso primário incompleto e que $52,8 \%$ dos doentes com antecedentes de abandono não estavam inseridos na produção, encontrando-se desempregados e desocupados, grupo em que a associação com o alcoolismo atingiu 51\% (OLIVEIRA, 1997).

É importante mencionar que todos os estudos mencionados anteriormente utilizaram um referencial metodológico que fatorializa a causação da doença, não permitindo outro tipo de achados que ajudem a revelar mais profundamente os processos que levam à não adesão ao tratamento.

Sem deixar de lado a compreensão de que formações sociais distintas exibem perfis epidemiológicos diferentes, com específicas determinações dos processos de adoecer e morrer, há estudos que ressaltam que as mulheres e os jovens são os que apresentam maiores taxas de cura e de adesão, como é o caso de VAN DER WERF e DADE (1990), em estudo realizado em Ghana (África). CHUAH (1991), na Malásia, identificou maiores taxas de adesão em "donas de casa". Infelizmente, mais uma vez esses autores não aprofundaram na investigação desses dados e o primeiro conjunto de autores acima referidos indicou que baixos níveis educacionais não têm associação com a baixa adesão ao tratamento.

Por outro lado, FERRER et al. (1991), ao realizarem estudo prospectivo na região metropolitana de Santiago (Chile), para estimar a magnitude da adesão ao tratamento semelhante ao utilizado no Brasil, verificaram menor taxa de adesão em pessoas do sexo masculino, menores de 45 anos de idade, solteiros, sem trabalho fixo, sem teto, além de alcoólatras e, ao contrário do que expôs CHUAH (1991), afirmam que o baixo nível educacional interfere na adesão ao tratamento. 
Alguns autores que imputam exclusivamente ao doente a responsabilidade pelo êxito da cura muitas vezes polarizam essa afirmação, argumentando que os médicos deveriam permanecer alertas para o fato de que, via de regra, os pacientes "mentem" quando referem que tomaram seus medicamentos, conforme coloca SBARBARO (1990/1991). O autor recupera Hipócrates e admite que ele foi o primeiro a prevenir os médicos sobre essa possibilidade. Aponta ainda que a porcentagem de pacientes que não tomam medicamentos de forma adequada varia de 20 a $82 \%$ e que a porcentagem de pacientes que toma medicamentos mas que comete erros na dosagem varia de 25 a $59 \%$. Ora, essa afirmação, sem dúvida, carece de uma discussão mais ampliada, na medida em que envolve uma multiplicidade de questões que podem determinar essa atitude. $\mathrm{Na}$ falta de interpretações mais totalizadoras, acatar tais argumentos pode resultar em ações por parte dos profissionais de saúde que não levem em conta o processo de vida dos clientes portadores de tuberculose pulmonar, o que seria de grande valia para a compreensão dessa situação.

Há que se notar que a adesão ou não ao tratamento não se reduz ao seguimento ou à desobediência da prescrição médica. A adesão, como lembra HAYNES (1989a), compreende ainda uma série de questões, dentre as quais aquelas que se referem exclusivamente às drogas. $\mathrm{E}$, nesse sentido, drogas que apresentam reações ou efeitos colaterais repercutem definitivamente no potencial da adesão ao tratamento.

No que toca às drogas que são utilizadas no tratamento contra a tuberculose, sabe-se que produzem uma série de reações como sintomas de neuropatia periférica, náuseas, vômitos, icterícia, asma, urticária, manifestações hemorrágicas, artralgias, perda de equilibrio, diminuição da audição ou alterações visuais (MINISTÉRIO DA SAÚDE, 1988b).

Sobre essa última questão é digno de nota que os pacientes podem apresentar, em geral, pelo menos dois tipos de comportamentos, que variam da exacerbação da queixa relacionada aos efeitos colaterais, mesmo que estes não sejam tão intensos ou, por outro lado, de posse de informações sobre a possibilidade de ocorrência de efeitos colaterais, os pacientes toleram o uso das drogas, pois temem mais o processo de adoecimento. À título de exemplo dessa última possibilidade, GUPTA et al. (1992) desenvolveram na Índia um estudo com 60 pacientes acometidos por tuberculose 
pulmonar que nunca haviam recebido quimioterapia no passado e os dividiram em dois grupos. Um deles foi informado sobre a provável ocorrência de anorexia e/ou vômitos em decorrência da medicação. Os autores verificaram que foi menos comum o relato de toxicidade nesse grupo do que naquele no qual nenhuma pessoa havia sido informada a respeito da ocorrência de reações.

No entanto, há autores que acreditam que a orientação do paciente sobre o que ele pode vir a apresentar não garante o sucesso do tratamento. A esse respeito, TOMAN (1980) afirma que, mesmo que se tenha informado o paciente acerca do seu problema de saúde, ele é "demasiado ignorante" para compreender a necessidade fundamental de se medicar durante longo tempo. É evidente que essas interpretações, da forma como estão apresentadas pelos autores mencionados, tendem a ocultar uma parcela das reais determinações pelas quais o paciente deixa de aderir ao tratamento medicamentoso.

TOMAN (1980) defende ainda que o paciente crê que, quando os sintomas deixam de aparecer e ele se sente bem novamente, já não necessita mais do medicamento. Vale dizer que há referência que indica que, devido a isso, a taxa de abandono pode ser maior no início do tratamento (CHUAH, 1991). É bem verdade que essa possibilidade existe e não deve ser deixada de lado quando o profissional de saúde introduz a terapêutica contra a tuberculose pulmonar. A melhora da sintomatologia pode repercutir de forma tal na atividade do doente que a doença deixa de ser sua inquietação preponderante, levando-o ao "esquecimento" deliberado do uso da medicação (CRESPO et al., 1992). Por outro lado, quando os sintomas não desaparecem tão prontamente ou mesmo quando aparecem reações indesejáveis pelo uso da medicação, o paciente pode entender que o tratamento foi prescrito de forma equivocada, abandonando-o.

Aparentemente buscando ampliar um pouco mais a compreensão da problemática, BARNHOORN e ADRIAANSE (1992), ao compararem 2 grupos de pacientes aderentes e não aderentes ao tratamento, em Wardha, na Índia, entre 1988 e 1989, observaram que a motivação, a percepção sobre a severidade da doença, sobre o seu próprio processo saúde-doença, além da eficácia das drogas, são fundamentais para o sucesso da adesão. Esses autores confirmam a relação entre o suporte social e a cooperação dos doentes que, conjugados, resultariam em melhor adesão. Colocam em evidência ainda a associação positiva entre o conhecimento dos aspectos específicos da 
doença, assim como da origem da tuberculose e das caracteristicas do regime terapêutico na efetividade da adesão ao tratamento.

Parece não haver dúvida de que é muito dificil localizar com precisão algumas situações/condições que levariam as pessoas a deixarem de completar o tratamento. SUMARTOJO (1993) ao fazer referência a documento emitido pelo CDC dos EUA, o qual sintetiza depoimentos de profissionais de saúde sobre a questão, coloca alguns exemplos que serão listados a seguir que seriam considerados como características ou preditores de baixa adesão. São eles: os sem teto, drogadição, história prévia de baixa adesão, distúrbio emocional, falta de transporte para dirigir-se à unidade de saúde, problemas comportamentais, insatisfação com a assistência à saúde, esquecimento, retardamento mental, carência de suporte familiar, migração, nível educacional, desemprego, baixa renda, constituir-se em minoridade étnica e/ou racial. Conforme a própria autora chama a atenção, as situações anteriormente consideradas refletem as observações e a experiência profissional mas excluem questões estruturais, operacionais e aquelas relativas ao espaço geográfico. Além disso, a pesquisadora alerta para o fato de que algumas variáveis que constantemente têm sido apontadas como preditoras de baixa adesão (como por exemplo, idade, renda, ocupação, dentre outras) não são inerentemente causais, mas representam outras situações/condições que constituir-se-iam como causais.

Esses achados paradoxais evocam a necessidade de proceder a análises mais amplas que busquem o entendimento dos processos que se operam e que acabam por determinar a adesão ou não ao tratamento. É necessário discriminar as diferenças existentes entre as distintas formações sociais cujos processos históricos de desenvolvimento e de estruturação implicam em diferentes formas de determinação de adoecimento e morte. Portanto, dentre tantos determinantes, é fundamental o resgate da individualidade desses pacientes, tendo como contraponto o contexto maior em que se configura na estruturação da sociedade, na forma como as pessoas inserem-se no sistema de produção, além da forma como se estruturam as políticas de saúde e nestas, a organização dos serviços e a sua disponibilidade para os pacientes, no acesso destes aos serviços de saúde. Afinal, em 1972, ROUILLON, já indagava até que ponto a responsabilidade pela não adesão pode ser imputada exclusivamente ao doente que 
tradicionalmente é denominado como "negligente", ou à população em geral, que tem sido descrita como "não-cooperante"? A maneira como diferentes autores tratam essa gama de questões será objeto de atenção no capítulo seguinte.

\subsubsection{As Limitações do Programa de Controle da Tuberculose: quando outras questões entram em cena}

Conforme mencionado anteriormente, ora se tem imputado os resultados limitados do Programa de Controle exclusivamente aos clientes portadores de tuberculose pulmonar, ora o insucesso deste tem sido colocado na dimensão relativa à produção dos serviços de saúde. No que toca a esta última, as questões referem-se especificamente à duração do tratamento (WORLD HEALTH ORGANIZATION, 1990), à eficácia das drogas (MINISTÉRIO DA SAÚDE, 1988a), ao custo e à resistência às drogas (GERHARDT e RIBEIRO, 1995), ao acesso aos serviços (MURRAY et al., 1990; VAN DER WERF e DADE, 1990) e à infra-estrutura do próprio programa em termos de disponibilidade de mão-de-obra qualificada.

Em relação à questão do acesso aos serviços, em estudo conduzido em Barcelona, Espanha, CRESPO et al. (1992) verificaram que os pacientes apontam a pequena margem de horário de atendimento pela unidade de saúde como um dos obstáculos na adesão ao programa. No entanto, cabe registrar que o acesso aos serviços não deve ser reduzido à distância ou ao horário de atendimento, como elementos pontuais da estrutura de organização dos mesmos. Há que levar em conta a possibilidade concreta de acesso enquanto disponibilidade do serviço para atender às necessidades de saúde que se articulam às sociais. Assim sendo, a abrangência das ações das unidades de saúde deveria ser maior, incorporando a eqüidade no acesso aos serviços como uma condição necessária para a transformação da qualidade de saúde dos cidadãos.

No que se refere à questão relativa à disponibilidade de mão de obra qualificada, MURRAY et al. (1990) argumentam que é necessário assegurar que o paciente compreenda como e porque deve tomar a medicação e questionam se a relação médico- 
paciente tem efetivamente respondido a essa demanda. Nesse sentido, é interessante observar que, apesar de se referir ao conjunto dos profissionais que compõem a equipe de saúde, os autores acabam por reduzir essa questão à relação biunívoca médicopaciente, além do fato de que não apontam como um problema o desconhecimento médico em relação à terapêutica padrão para a tuberculose. No entanto, BICICA et al. (1991), em estudo realizado na Romênia, propõem a necessidade de articulação da equipe de saúde com psicólogos ou com psiquiatras, identificando a interdisciplinaridade como uma peça fundamental para o aumento da adesão.

HULKA (1989) em um estudo desenvolvido em Indiana, EUA, concluiu que quanto menor o número de drogas prescritas, maior é a adesão. Recomenda que a escolha de regimes compatíveis com os hábitos diários dos pacientes ou eventos da vida deve reduzir o número de erros. É nessa mesma linha que coloca que a adesão depende do conhecimento do doente sobre a função das drogas.

\subsubsection{As Proposições para a Mudança da Realidade Segundo a Literatura}

A questão da adesão, não enquanto conceito, mas enquanto categoria de análise, exige cuidado na interpretação das inúmeras reflexões e experiências que têm sido produzidas ao longo dos anos, uma vez que trazem à tona diferentes perspectivas de abordagem e solução do problema. Da mesma forma que anteriormente foi assinalado, quando os autores imputavam o fracasso do programa de controle da tuberculose ao indivíduo ou à produção dos serviços de saúde, relacionam possibilidades de encaminhamento que de maneira geral são orientadas para a questão singular da doença. Assim, a série de proposições apontadas pelos autores para dar conta da transformação da situação da adesão dos clientes ao tratamento foi agrupada a seguir, na tentativa de facilitar a sua descrição.

Uma alternativa largamente empregada a partir da década de 60 , principalmente nos EUA, e subseqüentemente difundida para os países da América Latina, refere-se à “educação sanitária", na tentativa de mudar o comportamento dos doentes, reorientandoos para a adesão ao tratamento. Entretanto, tal alternativa não se apresentou como a 
"solução" para a maioria dos problemas de saúde das populações, entre eles a tuberculose, diferentemente do que se propusera, uma vez que, dentre outras limitações, deixava de considerar a totalidade da vida dos indivíduos e da coletividade, ao tocar somente nas causas emergenciais e de ordem biológica (BARREIRA, 1992). Ao estudar os fatores que influiriam no abandono do tratamento, KLEEBERG (1986) verificou que a educação sanitária em hospitais para o tratamento de tuberculose apresenta de fato uma durabilidade bastante breve. Adverte que uma das "lições" que aprendeu foi a de que a cura depende particularmente da prevenção do abandono, concluindo que a administração dos medicamentos duas vezes por semana, em um consultório ou no local de trabalho poderia se constituir em uma solução para a consecução da adesão.

TOMAN (1980) propõe que o fenômeno do abandono seja analisado com atenção, uma vez que o paciente pode deixar de seguir o tratamento, na medida em que outras demandas, próprias da vida, manifestem-se e centralizem seus esforços. Nesse sentido, os profissionais de saúde devem estar preparados para compreender esse processo e intervir de forma mais ampla e efetiva. Não basta, portanto, segundo o autor, a tão propalada "educação sanitária", com a finalidade restrita de mudar o comportamento do paciente, sem visualizar outras questões fundamentais que se referem à sua própria sobrevivência, para garantir que os pacientes cumpram com a prescrição medicamentosa. Sobre esse fato é interessante verificar a descrição bastante minuciosa que apresenta BERTOLLI FILHO (1993), a respeito da história como a educação sanitária foi fartamente utilizada como instrumento de "moralização" dos costumes para a diminuição da incidência da tuberculose.

Ainda no que toca às proposições dos autores para o aumento da adesão, é interessante verificar que algumas estratégias que eram utilizadas nos tempos antigos, ainda têm sido usadas por certos autores. BICICA et al. (1991), em estudo desenvolvido na Romênia com 124 pacientes, sugerem o isolamento compulsório dos pacientes que não aderem ao tratamento. BAYER et al. (1993) também sugeriram tal confinamento ao realizarem estudo em Nova York-EUA. Além disso, enfatizam que especial atenção deve ser dada aos "sem teto", aos usuários de drogas, bem como às pessoas que apresentam problemas mentais. Evidentemente que essa alternativa deve ser alvo de análise criteriosa pois pode ampliar a marginalização e a estigmatização que sempre tem acompanhado a 
tuberculose ao longo da história. $O$ isolamento compulsório deve ser uma alternativa para alguns casos estritos que realmente demandariam esse tipo de intervenção.

Seguindo uma outra linha de proposições, HILL e RAMACHANDRAN (1992), a partir da constatação de que a tuberculose constitui-se em um dos maiores problemas de saúde na Índia, descrevem um método para aumentar a adesão ao tratamento. Relatam que uma taxa era cobrada do paciente no seu início, a qual era reembolsada por ocasião da alta. Os autores referem que esse procedimento resultou em uma integralização do tratamento em $62 \%$ dos casos.

FARMER et al. (1991), em estudo realizado no Haiti em 1990, onde o programa de controle da tuberculose é bastante conhecido pela sua ineficácia, verificaram que o uso de incentivos como ajuda financeira ao paciente, transporte para ir à unidade de saúde mensalmente, além da realização de visitas domiciliárias periódicas, resultaram na redução da mortalidade, aumento da taxa de cura, bem como na diminuição do absenteísmo no trabalho. Os autores tentam uma abordagem mais abrangente e enfatizam ainda que a taxa de cura pode aumentar na medida em que os profissionais de saúde conhecem as questões de ordem econômica que interferem no processo saúde-doença.

Já a Organização Mundial da Saúde, órgão máximo que normatiza as ações de saúde para o conjunto dos países, aponta que em alguns locais e circustâncias, a hospitalização tem sido indicada como elemento crítico para a obtenção de resultados da ordem de $100 \%$ de adesão aos regimes de terapia de curto prazo, apesar de considerar sem valor a adoção dessa medida de forma isolada no controle da tuberculose (WORLD HEALTH ORGANIZATION, 1990).

Há autores que propõem o uso de "ordens judiciais" para o aumento da adesão. Essa estratégia, juntamente com a supervisão direta do tratamento, foi utilizada durante o período de 1986 a 1991 no South Caroline Department of Health and Enviromental Control e no New York City Department of Health, nos EUA (CENTERS FOR DISEASE CONTROL, 1993b). 
Outros advogam o uso de outras estratégias, tais como a contagem dos medicamentos. A respeito dessa estratégia, chega-se inclusive a sugerir a realização de visitas domiciliárias por enfermeiras, sem agendamento prévio com os pacientes, buscando com isso garantir que a situação de fato seja explicitada, ou seja, se o doente de fato tem tomado a medicação segundo as orientações médicas. Outras ações incluem desde a realização de testes de urina para a deteç̧ão das drogas ou a prova de outros metabólitos (POZSIK, 1993).

É ilustrativo resgatar os dados encontrados em um estudo conduzido por BRUDNEY e DOBKIN (1991a). Ao compararem os programas levados a cabo em Managua (Nicaragua) e em Nova York (EUA), encontraram uma série de diferenças significativas, sendo que em Managua a taxa de cura situava-se em torno de $80 \%$. Nova York, apesar de se constituir em uma metrópole de país desenvolvido, apresentou taxa de cura de $50 \%$ sendo que, em algumas áreas, obteve-se taxas inferiores a $15 \%$. A interpretação dos autores reside no fato de que, em Managua, $100 \%$ da terapia é supervisionada durante os 2 primeiros meses de tratamento, época em que ocorre o maior número de abandonos, sendo que as visitas domiciliárias são realizadas sistematicamente quando os pacientes faltam às unidades de saúde. $O$ que se verificava em Nova York era que menos de $2 \%$ dos pacientes que faziam tratamento eram submetidos à supervisão e as visitas domiciliárias eram realizadas com atraso de semanas a meses. Isso ajuda a explicar, ainda que em parte, o retorno explosivo da doença nessa última localidade na década de 80 .

A administração supervisionada de medicamentos é uma das estratégias que atualmente tem causado impacto no aumento da adesão dos pacientes ao tratamento. VAN DER WERF e DADE (1990) a recomendam e indicam que essa alternativa, efetivada durante a primeira fase do tratamento de curta duração, além de sua manutenção através de 2 ou 3 encontros semanais, tem sido efetiva na redução da taxa de abandonos em Ghana, na África.

SUKRAKANCHANA et al. (1992) recomendam o tratamento supervisionado, após ter conduzido estudo durante um período de 10 anos, com doentes que apresentavam baciloscopia positiva em acampamento de refugiados na Tailândia. Outros 
autores que adotam a mesma proposição são MENZIES et al. (1993), que realizaram estudos em Montreal, Canadá, quando tiveram a oportunidade de proceder ao seguimento íntimo dos casos igualmente para uma população restrita.

A ressurgência explosiva da tuberculose em âmbito mundial determinou que em 1994 a OMS recomendasse a aplicação da estratégia do tratamento supervisionado para todos os casos de tuberculose (WORLD HEALTH ORGANIZATION, 1997).

Em função dessa situação, o Ministério da Saúde do Brasil estabeleceu o Plano Emergencial Para o Controle da Tuberculose, no qual o tratamento supervisionado é indicado para os pacientes que apresentem maior risco de abandono (MINISTÉRIO DA SAÚDE, 1996b).

Uma outra alternativa que tem sido utilizada para assegurar a adesão do doente ao tratamento refere-se ao tratamento intermitente, o qual tem como característica a tomada dos medicamentos duas ou três vezes por semana. As doses são mais elevadas em cada tomada, mas a dosagem total é inferior à registrada nos regimes de uso diário (MINISTÉRIO DA SAÚDE, 1994b). A quimioterapia intermitente foi efetivada no clássico estudo em Madras, Índia ${ }^{1}$, e é defendida por vários investigadores (CHMELEV e ALYABINA, 1972; TRIPATHY, 1972; FOX, 1972; FOX e MITCHISON, 1975; CASTELO FILHO, 1993; MINISTÉRIO DA SAÚDE, 1994b).

SAMARASINGUE et al. (1991), em estudo retrospectivo combinando o tratamento intermitente e supervisionado envolvendo 16 pacientes na Nova Zelândia, concluem que essa modalidade de tratamento possibilita cura para grupos de risco como alcoólatras e para os "sem teto", além daqueles que se apresentam desmotivados para o seu seguimento.

A maioria dos autores têm preconizado o uso de regimes terapêuticos de curta duração, os quais seriam superiores em termos de eficácia, adequação e taxas de abandono. GEOFFREY (1989) aplica um modelo epidemiológico para analisar as tendências de evolução das taxas de incidência/abandono do tratamento na Indonésia, 
evidenciando que os regimes de tratamento de curta duração (de seis meses), empregando Rifampicina, Isoniazida e Etambutol, reduziriam em cerca de $65 \%$ as taxas de incidência em um período de 20 anos.

BRANDLI et al. (1993), defendem o uso de tabletes, denominados "Rifalter", que combinam as drogas para o tratamento da tuberculose, através de apresentação única. Os autores realizaram estudo controlado envolvendo pacientes na Suíça, o qual resultou em maior adesão para aqueles que fizeram uso dos tabletes. $\mathrm{O}$ Brasil, há alguns anos, tem à disposição a rifampicina associada à isoniazida.

MARTINY et al. (1992) ampliam a discussão para o âmbito da organização dos serviços ao situar o processo de descentralização das ações de controle da tuberculose que teve lugar na Nigéria, desde o ano de 1985, como um importante elemento da diminuição da taxa de abandono: de $42 \%$ para 19\%. No Brasil, as avaliações epidemiológicas têm apontado que o processo de reformulação do sistema de saúde, que tem como uma das diretrizes a descentralização das ações de saúde, parece não estar sendo acompanhado do aumento na adesão ao Programa de Controle. Explica-se essa constatação pelo fato de que esse processo não tem sido amplamente implementado no país, o que vem produzindo situações críticas em termos de precariedade na organização dos serviços de saúde, evidenciando resultados diferentes para os vários municípios em função da adoção dessas diretrizes ou da omissão frente à reestruturação do sistema de saúde brasileiro (HIJJAR, 1993; SÃO PAULO, 1993).

Como se pode verificar através da descrição feita até o momento, a maioria dos trabalhos procedem a análises sobre a questão da adesão dos pacientes ao tratamento a partir do simples arrolamento de "fatores" que podem determinar ou contribuir para o fracasso dos programas de controle. Os planos de intervenção propostos tradicionalmente têm focalizado o próprio indivíduo, especificamente tratando $\mathrm{da}$ dimensão biológica da doença, sem indagar e buscar elementos que contextualizem o seu processo saúde-doença. Poucas têm sido as tentativas que articulam a questão da adesão aos programas de controle, ao processo do vivenciar a doença numa perspectiva mais ampla, histórica, social, que explicite a realidade como se desenvolve a enfermidade, articulando o processo de sobrevivência aos processos de ordem estrutural, de conformação das políticas públicas, conforme preconiza BREILH (1986). 
O diagnóstico da tuberculose não é decodificado para os doentes como um conjunto de sinais e sintomas que constituem uma doença qualquer. A doença, ainda que na atualidade, determina ao tuberculoso o viver sob a estigmatização e a marginalidade. Há que lembrar que conviver com o "código" tuberculose, por um período de pelo menos 6 meses até que seja dado o veredito final da cura é um tempo demasiadamente longo e que exige dos doentes um enfrentamento da vida que se traduz num processo de sobrevivência bastante particular o qual, via de regra, os estudos deixam de evidenciar.

ROSEN (1979) ainda que não se reportando exclusivamente à tuberculose, concebe a doença como um processo biológico e social. Neste sentido, a doença "não existe como natureza pura, mas é mediada e modificada pela atividade social e pelo ambiente natural que tal atividade cria". Ora, essa concepção proporciona uma maior visibilidade da determinação do processo saúde-doença que tem a tuberculose como uma das expressões.

FACCHINI (s/d) argumenta que é necessário reconhecer a historicidade do ser humano, que resulta do modo específico de se apropriar da natureza através de determinadas formas de organização social para se entender a rede de determinações da saúde-doença. Portanto, na perspectiva da determinação social do processo saúdedoença, essa unidade dialética constitui-se como um processo social, uma vez que, historicamente, os processos bio-psíquicos humanos têm se transformado em função das transformações sociais. Essa concepção não contrapõe o social ao biológico, mas o social ao natural, já que o biológico é, em si mesmo, histórico e social (BREILH, 1986).

Por fim, é possivel depreender que a questão da adesão dos doentes ao tratamento constitui apenas uma das questões a serem desvendadas, no conjunto do processo de vida dos pacientes com tuberculose. Parece não haver evidências de estudos que se aprofundem na investigação do porque algumas pessoas com tuberculose terminam o seu tratamento, mesmo considerando todas as dificuldades inerentes ao seu enfrentamento. O que os torna diferentes daqueles que abandonam o tratamento? $\mathrm{O}$ que os faz vencer as barreiras e levar à termo um "empreendimento" tão dificil? É possível que, ao desvendar as respostas a essas indagações, se vislumbrem alternativas de solução que realmente impactem no controle da doença. Neste sentido, este estudo tem a 
finalidade de compreender a problemática da adesão do paciente ao tratamento, a partir da recuperação de uma dada totalidade que se constitui no vivenciar o processo saúdedoença da tuberculose pelas pessoas. 
Objetivos 


\section{OBJETIVOS}

\subsection{Geral}

- Analisar a questão da adesão das pessoas ao Programa de Controle da Tuberculose no Distrito Sanitário do Butantã, São Paulo.

\subsection{Especificos}

- Identificar as representações sobre o processo saúde-doença, a assistência prestada e a adesão ao tratamento do conjunto de pessoas que levaram à termo o tratamento nesse Distrito Sanitário.

- Verificar, nesse conjunto de pessoas, as articulações entre essas representações e a efetivação da adesão ao Programa de Controle da Tuberculose. 


\section{Metodologia}




\section{METODOLOGIA}

\subsection{A Opção Metodológica: considerações gerais}

Compreender questões da realidade social, que tem como característica imanente a dinamicidade, tal como preconiza MINAYO (1992), implica em examinar as relações complexas que se estabelecem entre o indivíduo e a sociedade, a ação, o sujeito e o objeto, o fato e o valor e entre a realidade e a ideologia.

É nesse sentido que é necessário dar conta de algumas especificidades: a de que o objeto é necessariamente histórico, uma vez que as sociedades humanas existem em determinados espaço e tempo. Também se deve considerar que os grupos sociais, as suas instituições, as leis, a visão de mundo, são provisórias, dinâmicas e encontram-se potencialmente em transformação (LACERDA et al., 1996).

A segunda especificidade é a de que o objeto de estudo possui consciência histórica, está submetido às grandes questões da época em que se vive e os seus limites são dados pela realidade do desenvolvimento social. Todos os indivíduos e todos os seus grupos, como também os pesquisadores, são dialeticamente autores e frutos do seu tempo histórico (MINAYO, 1992).

A terceira especificidade refere-se à identidade entre o sujeito e o objeto da investigação, os quais têm um substrato comum, o que os torna solidariamente imbricados.

Analisar a questão da adesão de doentes acometidos por tuberculose pulmonar ao Programa de Controle da Tuberculose e, mais especificamente, ao tratamento medicamentoso, constitui o ponto central a ser perseguido no presente estudo. A adesão parece não se constituir somente em um comportamento, mas está intimamente articulada à forma como o indivíduo vive e relaciona-se na sociedade e como é alvo da institucionalização de políticas. Assim sendo, verificou-se que a apreensão mais adequada do objeto poderia ser obtida através do uso de metodologia que 
proporcionasse a emergência de elementos que ajudassem a analisar a questão segundo uma perspectiva mais totalizadora. Partiu-se da premissa, conforme destacam NETTO e CARVALHO (1996) de que o método não é um componente inalienável da teoria, mas é uma relação necessária pela qual o investigador pode re-produzir (destaque do autor) intelectualmente $o$ processo do objeto investigado, para apanhar o movimento constitutivo do ser social.

No percurso para selecionar as teorias mais apropriadas que respondessem à necessidade desse olhar mais abrangente, verificou-se que as possibilidades teóricas perfaziam um universo bastante plural. Na realidade, o conhecimento só pode ser construído a partir da pluralidade, ou seja, do arranjo mais ou menos sistematizado e do aporte de diferentes teorias que buscam explicar a realidade. É GUARESCHI (1994) que apóia o raciocínio de que, na verdade, "diferentes teorias, de diferentes maneiras nos ajudam a compreender, ou explicar parte dos fenômenos. Não existe uma que explique todos os fenômenos, nem os aspectos todos de um único fenômeno". $\mathrm{E}$, conforme lembrava FERNANDES (1971) as teorias não devem ser formas rígidas de ortodoxia, mas orientar metodologicamente a análise dos fenômenos, tendo nesse sentido, muito mais a função de reguladoras que de disciplinadoras (SANTOS, 1997).

Foi com essa leitura que se decidiu que duas linhas teóricas fundamentais constituiriam as bases essenciais para a reflexão sobre o fenômeno da adesão ao tratamento da tuberculose e que se configurariam em referenciais possivelmente mais adequados para a compreensão do problema. São elas a Teoria das Necessidades, elaborada por Agnes Heller, e a Teoria da Determinação Social do Processo SaúdeDoença. Dessa forma, constituíram-se como categorias analíticas do presente estudo as representações sobre o processo saúde-doença e a adesão ao tratamento pelos doentes. Como será constatado adiante, verificou-se que também a representação sobre a assistência à saúde deveria compor o quadro de categorias de análise, uma vez que está articulada e que é inerente às duas já mencionadas.

A interpretação das representações das pessoas está assentada em uma visão histórica do processo saúde-doença. Nessa perspectiva, a vida humana não é estática, mas caracteriza-se por uma constante transformação, além de ser um processo 
essencialmente coletivo. O mundo real é contraditório e dinâmico e a realidade é conformada por processos gerais, particulares e singulares, ou seja, está intrinsecamente articulada aos processos de produção e de reprodução social, bem como com o aparato jurídico-político-ideológico. O processo de reprodução social refere-se à forma de organização da vida social e integra a vida laboral e do consumo, a vida organizativa, da consciência, da cultura e das relações sociais. Os processos biológicos da saúde são, portanto, parte do todo da vida social da coletividade. Dessa forma, a saúde e a doença são tomados dialeticamente como polos de um mesmo processo que se constitui como uma parte da totalidade maior que é a vida (BREILH, 1995).

Já a âncora reflexiva a partir da Teoria das Necessidades foi buscada em função de que esta coloca em questão elementos para o entendimento da realidade a partir da perspectiva dos sujeitos imersos em sociedade e, como tal, potencialmente repletos de necessidades na condução da vida. Ou seja, a análise da adesão ao tratamento da tuberculose não se limita ao simples ato de tomar ou não a medicação e de fatores que, seguindo alguma prioridade em geral definida pelos técnicos, correspondem ou não a essa demanda. Absolutamente: a idéia aqui é que essa dinâmica integra um processo maior que se conforma pelo sujeito numa determinada sociedade e que esse posicionamento está definido por uma série complexa de determinações que emanam de sua inserção social.

Segundo HELLER (1991), nessa Teoria, a essência humana não é o ponto de partida, nem o núcleo sobre o qual se superpõem as influências sociais, mas é um resultado, uma vez que desde o seu nascimento, o indivíduo encontra-se em uma relação ativa com o mundo e sua personalidade forma-se através dessa relação.

Assim, os processos reais são compreendidos a partir da análise do significado das interrelações na vida cotidiana. Esta, conforme a autora, é o conjunto de atividades que caracterizam a reprodução dos homens particulares. É evidente que o conteúdo e a estrutura da vida cotidiana não são idênticos em toda a sociedade e para todas as pessoas. A reprodução do particular é a reprodução do ser humano concreto, daquele que, em determinada sociedade, ocupa um lugar determinado na divisão social do trabalho. Como ente natural particular, o ser humano é um produto do desenvolvimento 
social. Percebe e manipula o mundo, partindo sempre de si mesmo, sendo que a sua apropriação do mundo decorre do objetivo de auto-conservação. Dessa forma, toda paixão, afeto e motivação e até mesmo o comportamento moral do homem, devem ser deduzidos dessa auto-conservação, que é a "consciência do eu, a relação sujeito-objeto, um objetivo".

Ainda conforme a mesma autora, todos os homens pertencem a uma determinada classe social que é histórica e que é a "substância da sociedade". Como membro de uma classe, cada particular não está em relação direta com ela, de sorte que as normas não são diretamente adquiridas, nem mesmo as exigências de sua classe, tampouco as próprias limitações e as limitações de classe. Os sistemas de exigências sociais aparecem mediados por grupos concretos, que constituem unidades, nas quais imperam as relações, denominadas por HELLER (1991) de relações "face-to-face". Essas são as determinantes ou as unidades nas quais esses sistemas de exigências estão representados por homens conhecidos e por relações humanas estruturadas.

A vida cotidiana é um objetivar-se em um duplo sentido, pois é um processo de contínua exteriorização do sujeito, ao mesmo tempo em que é um perene processo de reprodução do particular, constituindo-se o modo de vida como o conjunto de atividades cotidianas caracterizadas pela continuidade absoluta, no sentido de que ocorrem dia após dia. Mas, a vida cotidiana não é igual ao consumo e nem à vida privada. Ela evidentemente tem uma certa afinidade com o consumo, uma vez que o consumodesgaste sensu strictu tem lugar no marco da vida cotidiana. Nesse pano de fundo, o cotidiano é heterogêneo, isto é, as emoções e o uso das sensações não são iguais ou usadas ao mesmo tempo e as habilidades também são diferentes em cada indivíduo.

O sujeito particular constrói as suas representações acerca da realidade a partir de seu locus social e este, por sua vez, também define o conjunto de necessidades desse sujeito nessa determinada sociedade. Dessa forma, tanto as necessidades como as suas formas de satisfação variam segundo a inserção do indivíduo na sociedade (MENDESGONÇALVES, 1992). Os conteúdos dos carecimentos são representações que contém os traços individuais, mas que também expressam determinações complexas da ideologia hegemônica (LEOPARDI, 1992). 
HELLER (1986) advoga que as necessidades podem ser descritas como o sentimento consciente de "algo faltando". Necessitar é "carecer de" e as necessidades equivalem a carecimentos que, se não satisfeitos, podem determinar a manifestação do polo doença (LEOPARDI, 1992). O termo indica, assim, uma contingência, uma exclusividade, ou seja, se algo é necessário, o é de forma incondicional. Destaca ainda o fato de que o sentido que em geral se tem imputado à necessidade como algo intrínseco ao ser humano, imanente à sua natureza bio-psíquica, implica em uma compreensão limitada de sua origem, além de um empobrecimento nas formas de atendê-la.

Segundo HELLER (1986), a necessidade define-se sempre para um objeto, seja ele material ou imaginário, que realiza a satisfação do indivíduo que a incorpora. Assim, no caso da saúde, esta corporifica-se como uma necessidade não material que não se esgota em seu conteúdo primário, mas que se expressa também por seu conteúdo social. Além disso, a saúde é uma necessidade existencial, ou seja, é ontologicamente primária, fundada no instinto de conservação e o indivíduo introjeta o sistema e a hierarquia das necessidades "pré-constituídas pelo costume, pela moral...". Para LEOPARDI (1992), a necessidade é ao mesmo tempo pessoal e social pelo fato de que só a pessoa deseja algo, e porque o objeto de satisfação é fornecido pelo trabalho social ou é concretizado em uma outra pessoa.

A necessidade de saúde é um valor, que também incorpora em sua satisfação, o consumo de bens materiais e não materiais. Como resultado, o termo "necessidade" não denota um sentimento concreto em particular, mas muitos sentimentos distintos em qualidade que sinalizam uma falta ou ausência. Há sentimentos que sinalizam evidentemente uma falta como por exemplo, a fome, a curiosidade, a ansiedade e o amor, enquanto que outros não conduzem imediatamente a algo que pode ser facilmente materializável ou passível de corporificação (LEOPARDI, 1992). As necessidades são, portanto, sentimentos e simultaneamente forças motivacionais que aparecem como demandas pois as pessoas que as manifestam demandam a sua satisfação. Ora, o sentimento consciente de falta de algo é também uma motivação e, nesse sentido, a falta deve ser preenchida, eliminada. $O$ sentimento da falta de algo não equivale à insatisfação, na medida em que esta ocorre só se esse sentimento se perpetua ou se intensifica. Isto ocorre somente se os meios para a satisfação dessas necessidades, os quais Heller 
denomina "satisfatores", socialmente aceitos para uma pessoa ou grupo de pessoas não estão disponíveis para aquele grupo ou uma pessoa em particular; ou se esses "satisfatores" estão ao alcance da pessoa, ainda que não socialmente aceitos, orientam e informam a pessoa, nela criando necessidades, mas que não podem ser adquiridos. Há ainda situações em que a falta pode não ser preenchida ou eliminada por qualquer "satisfator", ou em que a pessoa sente a falta mas não sabe do que necessita (HELLER, 1986).

Para LEOPARDI (1992), o conceito de necessidade implica "na sua ligação imediata aos objetos que possam satisfazê-los, os quais se impõem como expressão de uma sociabilidade, como produtos do trabalho social ou incorporados num outro individuo, sob a forma de conforto, encorajamento, apoio e outras tantas manifestações de sentimentos humanos".

As necessidades de saúde não se constituem, conforme esta última autora, em generalizações ou em particularizações excludentes, mas como resultado de complexas interações entre o todo e as partes, entre o individual e o coletivo. Definem-se como carências específicas dos sujeitos, em relação a um tempo e lugar. A saúde compõe-se de uma série de valores representados por objetos materiais e não materiais que podem incorporar a noção da carência. Dessa forma, "quando o estar ativo (destaque da autora) indica saúde, o impedimento (seja dor, paralisia, fraqueza, etc...) se manifesta como doença. $O$ resgate da situação anterior só pode ocorrer quando o indivíduo que se sente doente olha para objetos (naturais ou produzidos) e os entende como capazes de anular sua limitação (analgésico, prótese, comida, etc...)”. Um aspecto sobremaneira importante refere-se ao fato de que o conceito de necessidades de saúde amplia-se para além dos aspectos puramente existenciais, alcançando também o nível simbólico, no qual crenças, valores e costumes assumem um papel fundamental. Assim, o conceito ultrapassa os conteúdos puramente naturais, incluindo aspectos que constroem a sua dimensão social.

Em relação às representações é necessário primeiramente compreender que esse conceito nasceu na Sociologia e na Antropologia, constituindo-se em objeto de estudo de Dürkheim e de Lévi-Bruhl. É um termo que, segundo MINAYO (1994), significa a reprodução de uma percepção retida na lembrança ou do conteúdo do pensamento. Nas Ciências Sociais, as representações são definidas como categorias de pensamento que 
expressam a realidade, justificando-a ou questionando-a. Dürkheim foi o primeiro a fazer uso do termo, referindo-se a categorias de pensamento através das quais determinada sociedade elabora e expressa a sua realidade. Marx Weber referia-se a elas como juizos de valor próprios dos indivíduos dotados de vontade, enquanto que Marx já apontava que os homens são produtores de suas representações e de suas idéias e as representações sociais constituem o conteúdo da consciência que, por sua vez, é determinada pela base material da existência (MARX e ENGELS, 1984).

A consulta à obra de Moscovici, um dos grandes defensores contemporâneos da teoria das representações sociais, ainda que fornecesse um potencial arsenal de respostas para o entendimento da questão da adesão na tuberculose, revelou-se um caminho insuficiente, dada sua ênfase no sujeito ativo, como construtor do mundo a partir dos materiais que a sociedade the fornece, mais do que estabelecendo conexões com a estrutura social, apesar dos intentos do cientista de introduzir a dimensão social no conceito (HERZLICH, 1991).

MENDES-GONÇALVES (1995) já alertava que não se deve proceder à redução do ser humano ao sujeito interacional, mas que é necessário ter em mente a sua totalização como ser sofredor, dotado de sensações, sensibilidades e de necessidades. $\mathrm{Ou}$ seja, há que superar o conceito de representação social situado no campo da psicologia social, dominada pela tradição behaviorista, que estabelece conexões diretas entre os estímulos e as respostas comportamentais (HERZLICH, 1991).

Trata-se, portanto, de incorporar a dimensão das singularidades de cada corpo, de cada indivíduo (GALLO et al., 1995) e, antes de tudo, de recuperar a subjetividade, mas tomando-a como um momento indissociável, mas não reificado, da objetividade. $\mathrm{O}$ ser humano revela-se como indivíduo particular, e é precisamente esta particularidade que faz dele um indivíduo e um ser comunal. Mas, segundo MENDES-GONÇALVES (1995), o ser humano é ao mesmo tempo uma expressão da totalidade, a existência subjetiva da sociedade. Nessa perspectiva, o processo histórico de constituição e vida dos seres sociais não é naturalizado, mas apresenta um sentido e um significado, sendo que a vida individual e a vida genérica do homem, isto é, este enquanto sujeito social na coletividade, não são diferentes. A representação social, assim, não é apenas um esforço 
de formulação mais ou menos coerente de um saber, mas também se refere à interpretação e à necessidade de dar sentido às ações e aos pensamentos.

Tomar as representações sociais como um campo socialmente estruturado implica em conceber as experiências individuais como decorrentes da realidade social na qual o sujeito está imerso, realidade esta que se apresenta sob a forma de campos sociais delimitados como por exemplo, a realidade familiar, do bairro onde vive a pessoa, da categoria profissional ou ao partido político ao qual pertence. Isso implica em entender que as condições sociais de inserção desses sujeitos determinam as suas representações e os discursos que as veiculam (JODELET, 1986).

Esse enfoque deve ser levado em conta integradamente àquele que concebe 0 sujeito como produtor de sentido, ou seja, como núcleo estruturante da ação. A relação dialética entre o polo individual e o polo coletivo promoverá um entendimento mais totalizante sobre as idéias e representações em função de um certo local ocupado no espaço histórico-social e geográfico. MANDÚ (1995) reafirma essa concepção ao postular que a realidade não se reduz às concepções que os sujeitos têm sobre ela. As representações são interpretações da realidade, histórica e subjetivamente construídas que constituem o mundo das idéias, ao mesmo tempo em que são os juízos de valor dos indivíduos sobre a realidade.

Segundo JOVCHELOVITCH (1994), "quando nós falamos em representações sociais, a análise desloca-se para um outro nível; ela já não se centra no sujeito individual, mas nos fenômenos produzidos pelas construções particulares da realidade social [destaque da autora]. Assim, o problema não está em abandonar o indivíduo porque ele implica necessariamente uma perspectiva individualista, ao contrário, o problema central é reconhecer que, ao analisar fenômenos (...) - representações sociais é necessário analisar o social enquanto totalidade [destaque da autora]. Isso quer dizer que o social envolve uma dinâmica que é diferente de um agregado de indivíduos". E mais: “... são as mediações sociais, em suas mais variadas formas, que geram as representações sociais". 
A interpretação cotidiana que as pessoas têm dos acontecimentos não se refere à sua simples opinião, mas reflete valores construídos e associados às ações. Para entendêlos pode-se lançar mão das representações sociais que, segundo MINAYO (1994), são categorias de ação e de sentimento que expressam a realidade e a explicam, justificam e questionam. Dessa forma, as idéias, concepções e visões de mundo que os grupos sociais possuem são oriundas, em primeira instância, da base material, ou seja, da forma como as pessoas se inserem no modo de produção, fato que vai determinar seu modo peculiar de viver a vida. A mesma autora coloca que as representações sociais são imagens construidas sobre o real e que se manifestam em palavras, sentimentos e condutas, devendo ser analisadas a partir da compreensão das estruturas e dos comportamentos sociais (MINAYO, 1994).

$\mathrm{O}$ que se quer deixar claro é que a maneira de pensar correlaciona-se com a forma como a sociedade está organizada, pois a consciência é um produto social, um reflexo das relações conflituosas entre os vários grupos sociais. Dito de outra maneira, a forma de pensar correlaciona-se com o modo de produção e com as estruturas de classe (MANDÚ, 1995). Não se está falando aqui, portanto, do ser humano apenas como produto da sociedade. $O$ conhecimento da realidade constitui-se na síntese das relações sociais e a partir da sua posição na sociedade os seres humanos constróem o conhecimento sobre o mundo, o qual reflete as contradições que são vividas na dimensão das relações sociais de produção. Assim, é possivel dizer, tal como GRAMSCI (1991) que o conhecimento é proveniente da posição social dos sujeitos, das suas experiências vividas e da sua situação no mundo.

As representações sociais são fruto da vivência das contradições que permeiam o dia-a-dia dos grupos sociais e "sua expressão marca o entendimento deles com os seus pares, seus contrários e com as instituições". Uma vez que correspondem às situações reais de vida, devem ser analisadas criticamente, pois não são reflexos nem cópias de conceitos adquiridos passivamente, pelo contrário, trazem nitidamente a marca da imaginação individual e coletiva (ROZEMBERG, 1994).

A expressão das representações sociais dá-se no plano individual, ainda que não sejam produzidas individualmente. Ao contrário, são construções sociais, uma vez que o 
conhecimento da realidade é também social. São construções contextualizadas e constituem reflexo das condições em que emergem. Assim, o sentido das representações não está no sujeito que conhece, “... mas na apropriação que o homem faz do mundo ao vivê-lo, ao construí-lo e ao construir-se" (MANDÚ, 1995). Dessa forma, as representações sociais não devem ser entendidas de forma unidirecional, apenas como reflexos dos contextos sociais, mas como elementos que integram a construção da realidade.

A opção empírica pelo discurso dos entrevistados deve-se ao fato de que a linguagem expressa a consciência (MARX e ENGELS, 1984). Para Marx, as representações sociais estão "coladas ao real", portanto, o seu estudo constitui-se em um dado sobre a realidade, informando sobre a base material na qual se move determinado grupo social. A palavra é o símbolo de comunicação por excelência, uma vez que representa o pensamento. Assim, a fala revela condições estruturais, sistemas de valores, normas e símbolos e tem o dom de transmitir as representações das pessoas, em condições históricas, sócio-econômicas e culturais específicas (BOERDIEU, 1972). Segundo LANE (1985), é o ponto de partida para se compreender as representações dos sujeitos, uma vez que é através dela que as representações são construídas e comunicadas. A linguagem oferece os signos e os símbolos que constróem as representações sobre a realidade, as quais permeiam todas as ações do sujeito, desde o pensar até o fazer. Da mesma forma, BAKHTIN (1986) define o caráter histórico e social da fala como um campo de expressão das relações e das lutas sociais.

As idéias e os discursos são, segundo FIORIN (1988), expressões da vida real, contendo as visões de mundo das pessoas que se materializam nas representações acerca dos elementos da realidade objetiva. $\mathrm{O}$ discurso "é uma rede de combinações, o conjunto de frases que exprime o pensamento do sujeito, seu entendimento do mundo exterior, do mundo interior ou do agir sobre a realidade".

Desta forma, através da linguagem, mais propriamente dos discursos de pessoas que vivenciaram a tuberculose e procederam à realização do tratamento integralmente, é que se buscou extrair as suas representações acerca desse processo, a partir da construção das suas próprias subjetividades como pessoas que vivenciaram a dinâmica do tratamento, enfrentando as dificuldades e as adversidades que dele decorrem. 


\subsection{O Percurso Metodológico}

\subsubsection{O Cenário do Estudo}

O estudo desenvolveu-se no Distrito do Butantã, que corresponde a uma divisão administrativa da Prefeitura do Município de São Paulo. Em 1993, a sua população era de 90.615 habitantes, que ocupava uma área de 12,9 quilômetros quadrados $(\mathrm{km} 2)$, com uma densidade demográfica de 7.024 habitantes/km2 (ADMINISTRAÇÃO REGIONAL DO BUTANTÃ, 1991).

Segundo dados da Prefeitura do Município de São Paulo (ADMINISTRAÇÃO REGIONAL DO BUTANTÃ, 1991), a micro-região do Butantã corresponde ao Distrito do Butantã que tem como limites geográficos, ao norte, a micro-região do Jaguaré e a Administração Regional de Pinheiros; ao sul e leste, as micro-regiões de Vila Sônia e Morumbi e a oeste, a micro-região do Rio Pequeno. Os principais bairros da microregião do Butantã são: Jardim Rizzo, Vila Indiana, Vila Pirajuçara, City Butantã, Inocoop, Jardim Ademar, Jardim Christe, Caxingui, Instituto Previdência, Cidade dos Bandeirantes, Jardim Matarazzo, Jardim São Gilberto, Jardim Pinheiros, Jardim Bonfiglioli, Jardim Esmeralda, Vila Gomes, Rolinópolis e parte do Jardim Peri-Peri.

As quatro favelas situadas na localidade totalizam 349 domicílios, com uma população estimada de 1.891 habitantes. Os estabelecimentos comerciais e de prestação de serviço são, em sua maior parte, de âmbito local e concentram-se principalmente ao longo da Avenidas Vital Brazil e Corifeu de Azevedo Marques.

Em termos de infra-estrutura, a rede de água encanada atinge toda a micro-região do Butantã. Quase todas as vias são pavimentadas e há três córregos: Pirajuçara. Pirajuçara-Mirim e Caxingui, sendo que 3,1 quilômetros não são canalizados, havendo três pontos críticos de enchentes.

Uma das características da região é a diversidade de equipamentos sociais. Há cinco centros culturais, além de centros educacionais e de lazer. No que se refere aos serviços de saúde, fazem parte da região o Hospital Universitário da Universidade de 
São Paulo (USP), o Hospital Vital Brazil do Instituto Butantã, o Hospital e Maternidade Jardim Sarah, além de sete unidades básicas de saúde da Prefeitura do Município, sete do Estado de São Paulo e o Centro de Saúde Escola Professor Samuel Barnsley Pessôa (CSEB) da Faculdade de Medicina da USP.

O presente estudo desenvolveu-se com pacientes matriculados nas unidades básicas de saúde da Prefeitura do Município de São Paulo, uma vez que a Escola de Enfermagem da USP, local de trabalho da pesquisadora, desenvolvia um projeto de integração docente-assistencial operacionalizado nessas unidades de saúde. Pela mesma razão foram acrescentados também os doentes matriculados no Centro de Saúde-Escola Professor Samuel Barnsley Pessôa (CSEB), da Faculdade de Medicina da USP.

\subsubsection{A População do Estudo}

A população que integrou o universo do presente estudo foi composta por 18 pessoas maiores de 18 anos de idade, ex-portadoras de tuberculose pulmonar, matriculadas nas unidades de saúde da Prefeitura do Município de São Paulo e no CSEB nos anos de 1995 e 1996 e que seguiram o tratamento para a tuberculose até a cura, tendo obtido alta.

O universo quantitativo populacional não foi definido a priori, sendo que o número de entrevistas foi baseado na compreensão de que, na pesquisa qualitativa, o critério de representatividade não é numérico. Segundo MINAYO (1992), a amostra mais adequada, nesse tipo de pesquisa é aquela que permite refletir a totalidade em suas várias dimensões. São valorizadas assim a reincidência de informações, bem como as informações ímpares, que realmente são fundamentais para o quadro explicativo da pesquisa (ANDRÉ, 1983).

O detalhamento sobre o universo de estudo encontra-se no ítem 3.2.5: "As etapas do trabalho". 


\subsubsection{As Sub-categorias Relativas ao Perfil Geral dos Clientes}

Conforme foi visto anteriormente, a posição que o indivíduo ocupa na sociedade e a forma como vive determinam o seu pensar e agir genericamente e, em particular, a forma como pensa e age em relação à saúde-doença. Assim, na busca de entender o seu locus social optou-se por proceder a uma caracterização social dos sujeitos, composta pelas categorias gênero, geração, mobilidade, educação, gregarismo, trabalho e ambiente físico e processo saúde-doença, operacionalizadas pelas seguintes sub-categorias (variáveis):

- $\operatorname{sexo}$

- idade

- procedência

- tempo de vida em São Paulo (capital e Estado)

- grau de escolaridade

- número de pessoas que compõem a família

- situação atual em termos de ocupação

- tipo de ocupação

- jornada de trabalho

- número de pessoas que compõem a renda familiar

- renda per capita

- tipo de moradia

- propriedade da moradia

- beneficios relacionados ao modo de vida (luz elétrica, água encanada, rua asfaltada, coleta de lixo, esgoto)

- meio de transporte majoritariamente utilizado

- vínculo com grupos da comunidade

- serviços de saúde utilizados (tipo)

- tempo dispendido para o deslocamento entre a moradia e a UBS

Essas sub-categorias foram sistematizadas, conforme pode ser visto através do Formulário em anexo (Anexo I). 


\subsubsection{Os Instrumentos Utilizados}

A caracterização das pessoas, bem como seus depoimentos foram obtidos através da aplicação do mesmo Formulário anteriormente mencionado (Anexo I), que continha 2 partes. $\mathrm{Na}$ primeira parte as perguntas buscavam verificar qual o perfil de algumas características pessoais e das condições materiais de existência, por meio de perguntas fechadas. Na segunda parte, que continha perguntas abertas, referia-se ao processo saúde-doença e buscava orientar o desenvolvimento do discurso do doente. Esta fase sofreu interferência mínima da pesquisadora, apenas na tentativa de aprofundar determinadas questões que pareciam importantes.

Cabe informar que a todas as pessoas foi esclarecido, em primeiro lugar, o objetivo da entrevista (Anexo II), informando-as sobre o caráter sigiloso a ser mantido em relação à sua identificação. Não houve nenhuma recusa para participar do estudo.

Outro aspecto importante refere-se ao fato de que, por ocasião da realização das entrevistas, foi possível perceber que a maioria das pessoas aproveitou esse momento como um espaço impar para a exposição de seus problemas e necessidades. Estas referiam-se a questões que envolviam a expressão clínica da tuberculose ou de algum outro processo patológico, além de aspectos relativos à sua vida e trabalho. Imbuída da necessidade de discutir estas questões que muitas vezes tinham em seu conteúdo indagações sobre a doença, a pesquisadora constantemente as retomava ao término das entrevistas discutindo-as com os pacientes e procedendo também ao seu encaminhamento para a unidade de saúde quando necessário.

Os depoimentos dos clientes foram gravados e posteriormente transcritos na integra pela própria pesquisadora.

\subsubsection{As Etapas do Trabalho}

A coleta de dados foi realizada no período correspondente a abril de 1996 a abril de 1997 e ocorreu em etapas. Num primeiro momento, buscando compreender qual seria 
o montante de casos de tuberculose na região do Butantã, mais especificamente no Distrito Sanitário do Butantã, recorreu-se ao Centro de Vigilância Epidemiológica da Secretaria de Saúde do Estado de São Paulo, que forneceu dados genéricos a respeito dos pacientes, como nome, data de notificação da doença, resultado do tratamento e unidade de saúde onde eram matriculados. De posse desses dados, foi necessário dirigirse ao Núcleo de Epidemiologia (NEPI) do Distrito Sanitário do Butantã, onde não havia um sistema de fácil acesso para a obtenção dos dados relativos aos pacientes que teriam terminado o tratamento, sendo necessário recorrer a um "caderno de registros" e avaliar a situação de cada um.

$\mathrm{Na}$ medida em que se limitou, num primeiro momento, o período de coleta de dados aos pacientes que houvessem terminado o tratamento durante o ano de 1995 , encontrou-se um número total de 10 pacientes para aquela região.

Além disso, faziam parte do universo de estudo, os pacientes matriculados no CSE do Butantã. Nesse Centro de Saúde, dada a facilidade de acesso das informações, uma vez que estão computadorizadas, foi possível prever um número potencial de pacientes, cuja viabilidade para integração no estudo foi verificada a partir da análise dos prontuários. Obteve-se dessa forma, outros 7 pacientes.

Para a realização das entrevistas com os pacientes foram feitas visitas aos seus domicílios obtendo-se, das 17 entrevistas em potencial, somente 10, em função das intercorrências que posteriormente serão apresentadas.

Uma vez que a transcrição das fitas foi realizada pela própria pesquisadora, verificou-se durante esse processo, que seria razoável verificar a possibilidade de ampliar o universo de temas que eram abordados pelos pacientes nas entrevistas e, desta forma, decidiu-se por recorrer novamente ao NEPI e, mais uma vez ao CSE, para a inclusão de novos pacientes, desta vez os matriculados durante o ano de 1996. Essa segunda tentativa fez incorporar, potencialmente, mais 47 pacientes, sendo 33 das unidades de saúde do Distrito Sanitário do Butantã e 14 do CSE do Butantã. A realização das visitas para as entrevistas evidenciou uma série de obstáculos e problemas, os quais serão detalhados a seguir, fato esse que fez resultar efetivamente em mais 8 depoimentos. 
Como pôde ser verificado, esse processo foi bastante lento, pois teve início em abril de 1996 e prolongou-se até abril do ano de 1997. Assim, de 64 pacientes em potencial, foi possivel ter acesso aos depoimentos de 18, o que resultou em somente $29,7 \%$.

Além das principais dificuldades que ocorreram durante a realização das entrevistas, vale apontar que, na medida em que o trabalho foi realizado na região onde a Escola de Enfermagem mantinha atividades de integração docente-assistencial, a pesquisadora dispôs de transporte dessa unidade, o que auxiliou sobremaneira o desenvolvimento da coleta de dados. Entretanto, a realização das visitas dependeu da rotina administrativa da Escola, o que também contribuiu para a lentidão dessa etapa. Não foram raros ainda os momentos em que a própria pesquisadora utilizou-se do seu próprio transporte para dar conta da tarefa em questão.

Os principais problemas e intercorrências foram:

- paciente com neoplasia de laringe, submetido à cirurgia, apresentava dificuldade de comunicação (1);

- o endereço não foi localizado/não existência do número da rua (20);

- visita realizada em 3 períodos diferentes, sem encontrar o paciente (5), sem contato com qualquer familiar;

- paciente não se encontrava no domicílio. Foi deixado o telefone para contato, sem sucesso, sendo que houve um caso em que foi possivel entrevistar um paciente cuja irmã também esteve sob tratamento, mas esta não retornou a ligação (7);

- paciente estava no trabalho, sem possibilidade de previsão para marcar entrevista (1);

- paciente sintomático respiratório, havia interrompido o tratamento, encontrava-se embriagado. Segundo referiu, após a implementação do Plano de Assistência à Saúde (PAS) do Município de São Paulo, não mais teve acesso à consulta médica na unidade de saúde na qual havia dado início ao tratamento (1);

- paciente havia interrompido o tratamento (1);

- paciente havia mudado de residência há 15 dias. O telefone para contato foi deixado, sem sucesso (1);

- paciente não morava no endereço, sendo que uma delas cumpria pena no cárcere (4); 
- paciente mudou para outro Estado (1);

- paciente continuava sob tratamento (2), sendo que um deles encontrava-se internado em Campos do Jordão;

- paciente falecera há 6 meses (1).

Como pôde ser verificado, foram realizadas 45 visitas sem sucesso. É digna de nota a quantidade de endereços incompletos ou inexistentes, o que evidencia uma falha no sistema de informação. Ademais, verifica-se o descontrole e a falta de sistematização dos dados, uma vez que foram encontradas situações impares, desconhecidas pela unidade de saúde, como abandono do tratamento ou então a sua continuidade, quando nas informações do NEPI constava que o paciente obtivera alta por cura.

Por outro lado, foram realizadas 27 outras visitas, além de 13 chamadas telefônicas, que resultaram em 18 entrevistas. Cabe ressaltar que esse processo foi extremamente penoso mas, ao mesmo tempo gratificante, uma vez que percebendo-se o desalento em que se encontrava o Programa, verificou-se também que ele se mantém, em grande medida, pela própria iniciativa dos pacientes. E nesse processo ocorreram:

- momentos em que a entrevista foi realizada na própria unidade de saúde (2), dentre as quais a de uma paciente que retornou à unidade especificamente para atender ao propósito de sua realização;

- a disponibilidade do paciente em prestar seu depoimento em 2 ocasiões, uma vez que, por ocasião da primeira vez, ocorreu um problema técnico com o gravador e isso não foi percebido pela pesquisadora no momento da realização da entrevista;

- a disponibilidade da paciente em atender à entrevistadora durante o fim de semana;

- a disponibilidade da paciente para entrar em contato com a entrevistadora (três chamadas telefônicas até o agendamento da entrevista);

- a disponibilidade dos vizinhos para fornecer informações sobre os pacientes;

- a disponibilidade do paciente em dirigir-se até o local de trabalho da pesquisadora para a realização da entrevista. 


\subsubsection{A Decomposição dos Discursos dos Sujeitos}

Conforme colocado anteriormente foram realizadas entrevistas, que foram gravadas, com os sujeitos que haviam completado o tratamento para a tuberculose integralmente. Após a transcrição na íntegra das entrevistas pela pesquisadora, procedeuse à análise do material empírico, através da técnica proposta por FIORIN e SAVIOLI (1991) e adaptada por CAR (1993), que está fundamentada na teoria de Greimas ou teoria da geração de sentido do texto, a qual permite a depreensão de frases temáticas (FIORIN, 1989). Segundo FIORIN (1988), "a análise vai mostrar a que formação discursiva pertence determinado discurso. O sujeito inscrito no discurso é efeito de sentido (destaque do autor) produzido pelo próprio discurso, isto é, seus temas e figuras é que configuram a visão de mundo (destaque do autor) do sujeito. Se, do ponto de vista genérico, as formações ideológicas materializadas nas formações discursivas é que determinam o discurso, do ponto de vista da análise, é o discurso que vai revelar quem é o sujeito, qual é sua visão de mundo". Evidentemente que não se trata de buscar entender a posição ideológica do sujeito enunciador, mas de revelar as suas visões de mundo.

As estruturas narrativas comportam elementos concretos e elementos abstratos. Os primeiros são denominados por FIORIN e SAVIOLI (1991) como figuras, "... palavras ou expressões que correspondem a algo existente no mundo natural: substantivos concretos, verbos que indicam atividades fisicas, adjetivos que expressam qualidades fisicas". Os elementos abstratos são chamados de temas, ou seja, "...são palavras ou expressões que não correspondem a algo existente no mundo natural, mas a elementos que organizam, categorizam, ordenam a realidade percebida pelos sentidos".

Os autores explicam que no texto todos os elementos se relacionam e o que dá sentido às figuras é um tema. Dessa forma, encontrar o sentido de figuras encadeadas é encontrar o tema a elas subjacente, conforme foi realizado no presente estudo. Os temas evidenciam os sentidos e os significados de cada ação contida no discurso. Na definição dos conteúdos das representações contidas nos depoimentos há um constante transitar entre a realidade e a teoria, num processo contínuo de interpretação sobre o que os dados significam, o que implicam e para onde levam. 
A teoria de Greimás está baseada na existência de uma gramática do discurso, ou seja, na existência de mecanismos que engendram o sentido do texto, ao que esse autor denomina de percurso gerativo de sentido. Na produção de um texto, realiza-se esse percurso partindo-se do mais concreto (as figuras), em direção ao mais abstrato (os temas) (BERTOLOZZI, 1991). Para analisar os depoimentos, procedeu-se então à sua desconstrução, à decomposição, partindo-se da estrutura narrativa, que é mais concreta, caminhando em direção da estrutura profunda.

Todos os depoimentos foram analisados seguindo essa orientação, buscando-se verificar quais eram os significados e a interpretação do grupo de pessoas acerca da doença e como concebiam a adesão ao tratamento. Um dos questionamentos que têm sido colocados à análise de discurso, diz respeito à impossibilidade do depoimento vir a traduzir a posição ideológica de seu autor. Argumenta-se, inclusive, que o sujeito enunciador poderia falsear seu discurso, fazendo com que fosse revelada uma maneira de ver o mundo que não a sua própria. Há ainda a questão, como bem o coloca FIORIN (1988), de que sendo tantas as formações discursivas quanto as formações ideológicas em uma sociedade, um mesmo discurso pode chegar a revelar mais de uma visão de mundo.

Porém muito mais do que verificar as condições de verdade dos depoimentos analisados, a pesquisadora se interessou por estabelecer sua veridicção, ou seja, compreender o que o depoimento tinha por verdadeiro. A análise feita sob essa inspiração não pretende colocar em cheque a posição ideológica do enunciador real, mas sim entender como o enunciador vê o mundo e, portanto, reconhecer, interpretar e reinterpretar as concepções dos entrevistados sobre o seu processo saúde-doença e a adesão ao tratamento.

FIORIN (1989) alerta para o fato de que muitas são as possibilidades de interpretação dos depoimentos, entretanto, esta deve estar sempre circunscrita ao espaço do que foi dito e, “...as várias leituras não se fazem a partir do arbítrio do leitor, mas de virtualidades presentes no texto".

Para a contextualização do estudo das representações foram privilegiadas a profundidade e a literalidade dos depoimentos dos sujeitos. Isso foi feito através de várias leituras de cada depoimento, buscando-se quais eram os temas que estavam subjacentes nos discursos dos doentes. Os depoimentos foram então decodificados e 
sintetizados em frases temáticas (Anexo III). Destaca-se, portanto, que as frases temáticas constituem as representações dos depoentes e não o seu discurso, já submetidas portanto a um processo de análise. Além disso, as frases temáticas encontram-se agrupadas segundo núcleos centrais que serviram para orientar o processo de apresentação e de discussão dos resultados (Anexo IV). Ainda é importante ressaltar que nem todas as frases temáticas foram utilizadas para análise, uma vez que privilegiouse aquelas que mais se relacionavam ao objeto de estudo. 


\section{Resultados e Discussão}




\section{Resultados E discusSÃo}

\subsection{A Descrição do Perfil de Características Pessoais: quem eram e como viviam os entrevistados}

As 18 pessoas entrevistadas estavam distribuídas de maneira mais ou menos uniforme no que se refere ao sexo: havia 10 mulheres e 8 homens. Foram encontradas 2 pessoas menores de 18 anos, 8 na faixa etária entre 20 e 30 anos, 3 entre 31 e 40 anos, uma entre 40 a 50 anos, 2 entre 51 a 60 anos e 2 entre 61 a 70 anos.

Quanto à procedência, 8 eram do Estado de São Paulo, sendo que 6 eram provenientes da capital e 2 do interior, sendo que estes últimos se encontravam há mais de 26 anos no Município de São Paulo. Outros 5 eram provenientes da Bahia e encontravam-se há mais de 10 anos em São Paulo, 2 vinham de Pernambuco e estavam há mais de 28 anos no Município, 2 do Rio Grande do Sul, sendo que uma estava há 2 anos e outra há 19 em São Paulo e, finalmente, um do Ceará há 14 anos em São Paulo.

No que se refere à religião, 11 pessoas referiram pertencer à religião católica e os demais distribuíam-se entre as religiões cristã, messiânica, crente, budista, sendo que um referiu não ter religião.

Quanto à escolaridade, verificou-se que 2 tinham o primeiro grau completo, 3 incompleto, 5 tinham o segundo grau completo, 3 incompleto, 1 tinha o terceiro grau incompleto e uma estava cursando pós-graduação. Vale dizer que foram encontrados 2 analfabetos e uma pessoa que não soube referir o seu grau de escolaridade, pois havia freqüentado a escola no interior da Bahia há muito tempo.

A maioria morava com mais de uma pessoa, sendo que 7 moravam com uma a três pessoas, 8 com quatro a seis e 1 com sete a nove pessoas. Foi também entrevistada uma pessoa que morava no emprego (casa de familia) e outro que morava sozinho.

No que toca ao trabalho, a maior parte das pessoas (10) estava trabalhando na época em que foram realizadas as entrevistas, sendo que as ocupações distribuiam-se principalmente no setor de serviços (4 pessoas), exercendo as atividades de babá, 
empregada doméstica, faxineira e eletricista. Havia 5 exercendo funções ligadas ao comércio, como representante comercial, comerciante, vendedor(a), e um era proprietário de bar. Uma pessoa recebia bolsa de estudos por estar fazendo pósgraduação e, dentre os demais, 4 referiram estar desempregados, um informou que ainda se encontrava afastado do emprego devido à doença e 2 eram estudantes.

Daqueles que referiram estar trabalhando, 3 informaram ter jornada semanal menor do que 40 horas; 2 igual a 40 horas e 5 disseram que trabalhavam mais do que 40 horas, sendo que 3 entre 41 e 50, uma entre 51 e 60 e uma afirmou trabalhar mais do que 61 horas por semana.

Dentre essas pessoas, bem como a que recebia bolsa de estudos e a que estava afastada do trabalho, três referiram receber até um salário mínimo (s.m.), quatro até 2 salários mínimos, uma até 3 s.m. e quatro até 6 salários mínimos. Na época em que o estudo foi realizado o salário mínimo variou entre cem a cento e doze reais (ANUÁRIO ESTATÍSTICO DO BRASIL).

$\mathrm{Na}$ maioria dos casos, além do paciente, outras pessoas da familia compunham a renda familiar, sendo que em quatro casos, 3 outras pessoas trabalhavam, em seis casos, 2 outras pessoas trabalhavam na famila, e em cinco casos somente outra pessoa ajudava na composição da renda familiar. Em um caso a renda familiar era composta apenas pela contribuição do ex-paciente. Cabe mencionar aqui que, no caso dos dois outros pacientes, um morava no conjunto residencial da Universidade de São Paulo e referiu não haver uma renda familiar e, no caso do último, morava sozinho, não se aplicando, portanto, a questão em pauta.

Ainda assim, na tentativa de verificar a renda per capita em cada familia, verificou-se que em 5 casos esta era de até $1 \mathrm{~s} . \mathrm{m}$./mês, enquanto que em 2 casos variou entre 1 a $1,9 \mathrm{s.m} . / \mathrm{mês}$, em um caso era de 2 a $2,9 \mathrm{~s} . \mathrm{m} . / \mathrm{mês}$, em 2 casos esteve por volta de $5 \mathrm{~s} . \mathrm{m}$./mês. Os demais referiram somente que a renda familiar era maior que $3 \mathrm{s.m}$. e que era dividida entre cinco, seis e até oito pessoas, sendo que em três casos os expacientes referiram não saber o montante familiar. 
No que se refere à moradia, a maioria $(72,2 \%)$ referiu ter casa própria, $22,2 \%$ alugada e em um caso a habitação era cedida. Todas as casas eram de alvenaria, sendo que $83,3 \%$ tinham mais de 3 cômodos, $11,1 \%$ tinham 3 cômodos e uma tinha dois cômodos.

Em relação aos beneficios, a totalidade das moradias era servida por luz elétrica e água encanada, sendo que $88,9 \%$ tinham rua asfaltada, $83,3 \%$ tinham coleta de lixo pelo menos 3 vezes por semana e $94,4 \%$ referiram ter rede canalizada de esgoto.

Para locomover-se, 11 utilizavam ônibus ou metrô, 4 usavam carro próprio, 2 ora usavam carro ou ônibus e um referiu locomover-se somente a pé.

Já no que se refere à agregação das pessoas, 12 referiram não participar de grupos da comunidade (por não dispor de tempo, por não ter vontade, por morar há pouco no endereço, por desconhecimento, dentre outros motivos), enquanto que os restantes informaram participar principalmente de grupos ligados à religião.

No que toca à utilização de serviços de saúde, 7 recorriam à UBS e Hospital Universitário e 2 à UBS e outro hospital público. Quatro pacientes faziam uso da UBS em conjunto com o convênio médico da empresa onde algum familiar trabalhava e três recorriam somente à UBS. Duas pessoas referiram utilizar a UBS, bem como algum serviço de saúde de caráter particular.

A maioria (13 pessoas) referiu que ia a pé à unidade de saúde, gastando até cinco minutos ( 5 pessoas), de 5 a 15 minutos (6 pessoas) e de 15 a 30 minutos ( 2 pessoas). Três pessoas referiram que iam de carro, gastando até 20 minutos e duas mencionaram que utilizavam ônibus, gastando até 15 minutos.

Os resultados encontrados permitem verificar que a maioria dos entrevistados pertencia à população em idade economicamente ativa, estando engajados no sistema de produção. Eram predominantemente provenientes do Estado de São Paulo e da região Nordeste do país e, além disso, tinham algum grau de escolaridade, moravam com mais de uma pessoa, sendo que a maior parte daqueles que estavam empregados tinha jornada de trabalho maior do que 40 horas semanais e recebiam até 2 salários mínimos. Viviam em habitações predominantemente próprias, de alvenaria, com mais de 3 cômodos, com 
luz elétrica, água encanada, esgoto, coleta de lixo e rua asfaltada. Locomoviam-se principalmente através do uso de ônibus ou metrô, não participavam de grupos da comunidade e recorriam a serviços públicos de saúde, tanto as unidades básicas de saúde da região, como o Hospital Universitário.

É possível dizer, portanto que se tratava de pessoas cuja inserção no sistema de produção lhes conferia possibilidades restritas em termos de qualidade de vida, corroboragndo os dados de literatura que verificam a maior incidência da tuberculose nos estratos sócio-econômicos menos privilegiados. É bem verdade que o número de pessoas é bastante limitado para que se possa proceder a comparações com outras realidades. Entretanto, a possibilidade de realizar as visitas aos domicílios para a realização das entrevistas revela um cenário que os números podem encobrir. Tratava-se de uma população que residia em região da periferia, sendo que algumas pessoas encontravam-se nos limites da exclusão social. Aqueles que se encontravam individualmente fora do sistema de produção tinham possibilidade de acesso ao consumo pela ajuda de familiares. Assim, trata-se de uma parcela da população que, ainda que sofrendo as consequiências da forma como trabalham e vivem, parece dispor de um certo suporte, mesmo que tênue e bastante frágil, possivelmente importante na adesão ao tratamento da tuberculose. Ao perfil encontrado em relação às condições de vida e de trabalho, soma-se a forma como pensam sobre a sua enfermidade, sobre a assistência prestada no serviço de saúde e como se desenvolveu o processo de tratamento que culminou com a sua cura. No próximo capítulo buscar-se-á verificar porque esses pacientes aderiram ao Programa de Controle da Tuberculose. procurando assim responder aos objetivos da presente investigação. 


\subsection{As Representações dos Doentes}

A análise das frases temáticas foi conduzida a partir das categorias analíticas: Processo saúde-doença, Assistência à saúde e Adesão ao tratamento, as quais foram examinadas à luz da Teoria das Necessidades e da Determinação Social do Processo Saúde-Doença. O primeiro aspecto a ser ressaltado, deve-se ao fato de que a exposição a seguir buscará as evidências entre as representações dos indivíduos e sua inserção na sociedade. Parte-se, portanto, dos processos que ocorrem na vida cotidiana e suas conexões com o macrosocial. A vida cotidiana é percebida e apresentada diversamente na "vida dos gestos, relações e atividades rotineiras de todos os dias; um mundo de alienação; um espaço do banal, da rotina e da mediocridade; o espaço privado de cada um, rico em ambivalências, tragicidades, sonhos ilusões; um mundo de existência social fictício/real, abstrato/concreto, heterogêneo/homogêneo, fragmentário/hierárquico (...); um espaço de resistência e possibilidade transformadora (...); um palco possível de insurreição, já que nele atravessam informações, buscas, trocas, que fermentam sua transformação" (NETTO e CARVALHO, 1996).

As representações dos sujeitos foram analisadas tendo-se em mente que a vida cotidiana não pode ser negada como fonte de conhecimento e de prática social, bem como na perspectiva de que as representações fazem parte do real cotidiano, sem perderse no imaginário. Além disso, parte-se do pressuposto de que o cotidiano é histórico, integrando os fatos da vida social numa totalidade e que é motor de transformações globais. Está-se remetendo, pois a três vertentes de apreensão da vida cotidiana que são focalizadas por HELLER (1991): busca do real e da realidade, totalidade e transformação.

Isto posto, as frases extraídas dos depoimentos dos sujeitos pesquisados revelam diferentes dimensões/facetas de cada uma das categorias analíticas que, evidentemente, guardam entre si articulação e dependência. A apresentação dos resultados que evidenciam cada uma delas será feita por blocos, sintetizando os conteúdos das representações. No Anexo IV pode-se verificar o detalhamento do conteúdo das representações em função de núcleos que centralizam temas que emergiram durante os 
discursos. Dessa forma, em primeiro lugar proceder-se-á à reflexão sobre a forma como os doentes representam a tuberculose.

\subsubsection{Representações sobre o Processo Saúde-Doença}

Em primeiro lugar, faz-se necessário apontar que as distintas representações que emergiram das entrevistas sobre o processo saúde-doença revelam a forma como está composta a imagem desses sujeitos a respeito de como a tuberculose desenvolveu-se em suas vidas. Além disso, conforme aponta HERZLICH (1991), as concepções sobre a saúde e a doença refletem em parte as imagens da sociedade, ou seja, a forma como esta se impõe aos sujeitos, determinando o processo de vida das pessoas.

As frases temáticas que a seguir serão apresentadas constituem o produto do tratamento analítico realizado para a depreensão das representações. $\dot{A}$ título de exemplificação, em algumas situações, a apresentação de certos trechos das falas originais das pessoas será feita em negrito.

A análise dos depoimentos evidenciou que a tuberculose permanece como doença impregnada de estigmatização, o que pode ser visto pela própria forma como as pessoas a ela se remetem: ora a enfermidade simplesmente não é nominada (9.7), ora é referida como "isso"; "esse negócio de doença"; "tb"; "coisa"; "minha doença"; "essa doença"; "problema"; "assunto"; "aquela doença", "horrivel", "chata", “desconfortável”, “algo errado", "um pesadelo”, "estranha” (1.12; 3.2; 4.26; 5.19; $5.30 ; 7.5 ; 8.5 ; 10.4 ; 11.26 ; 16.9 ; 17.17 ; 18.4)$. De igual modo, "as medidas de precaução apresentam conotação de repulsa ('aquilo lá') (5.14).

Como se pôde verificar, existe uma forma de não se relacionar imediatamente à doença, remetendo-a a um plano que se apresenta como exterior ao do doente. E, nesse sentido, é interessante apontar que o fato de não nominá-la como que isentaria a pessoa de vivenciá-la. Por outro lado, dada a complexidade com que se revela o estar doente, a enfermidade emerge como uma equação, um problema a ser resolvido. 
Não somente a tuberculose não é referida ou a ela se remete de forma tangencial, mas também o hospital e o tratamento são tomados como "lá", "horrivel", "meio pesado" (5.19), revelando concepções que trazem conotações de cunho aparentemente não positivo.

Verificou-se ainda que o nome da doença não foi lembrado pela pessoa durante a entrevista, mesmo tendo sido a enfermidade um processo que, no mínimo, consumiu 7 meses da vida do paciente (8.4). Outro aspecto se refere ao fato de que, em uma ocasião, o entrevistado não conseguiu lembrar o período de início da doença (9.1), sendo necessária outra pessoa da família para ajudá-lo a recordar (9.2).

A doença faz emergir uma série de sentimentos durante o período de tempo em que os sinais e sintomas não se configuram ainda como tuberculose, bem como posteriormente: "A doença/tb (tuberculose) se constitui em "experiência traumatizante" (11.7); "A tuberculose provoca "desânimo", "depressão" e "tristeza" (8.13), "nervosismo", "abalo do sistema nervoso", "medo", devido à possibilidade de ter que interromper as atividades de trabalho e, em decorrência, diminuição do poder econômico e da necessidade de cumprimento das 'obrigações domésticas' (alimentar, vestir e dar medicação aos filhos)" (15.7). Esses sentimentos estão diretamente relacionados às repercussões da enfermidade sobre o processo de produção social visto sob o ângulo do doente, ou seja, relacionados ao trabalho e tudo o que dele pode advir. Não se referem, portanto. apenas ao fato único de estar doente e na vivência da doença como um processo individual, mas do fato de que a enfermidade pode vir a determinar rupturas nas condições de existência.

Numa outra perspectiva, evidenciou-se também a seguinte representação: " $o$ sofrimento guarda correlação com a idade da pessoa ("é maior, quanto mais jovem"), uma vez que diminui a 'potencialidade' de viver" (2.47), o que põe à mostra um caráter de valorização que possivelmente reproduz o padrão que a sociedade ocidental tenta imprimir. Ou seja, há uma valorização do corpo no que toca aos aspectos que a sociedade contemporânea ocidental almeja, dentre os quais, a juventude e a beleza. Nesse caso, o fato da pessoa acometida pela doença ser jovem coloca em pauta a 
possibilidade de limitação dos projetos que potencialmente são desejados no curso da vida, os quais a enfermidade tem a potencialidade de conter.

HELLER (1985), ao descartar o sentimento como estritamente comportamental, explicado pela teoria behaviorista, defende que sentir significa estar implicado com algo, sendo que essa implicação pode ser de cunho positivo ou negativo, ativa ou reativa, direta ou indireta. Explica que a amplitude dessa implicação reativa encontra-se em relação direta com o grau de familiaridade gerado pela informação. Assim, quanto mais extensas as integrações e mais gerais os conceitos com os quais os indivíduos se identificam, mais amplo será o círculo da implicação. A implicação constitui-se como o fator construtivo inerente ao atuar e ao pensar e está determinada pelo organismo, processo que ela denomina de idiossicrasia biológica, mas também está determinada pelas circunstâncias sociais, denominadas por idiossincrasias sociais.

Aspectos que se referem à tuberculose, como a questão da morte, evidenciaramse metaforizados durante o discurso, sendo denominados por jargões de uso comum, como "agora eu vou”, "pessoa vai se apagar”, “embarcar dessa para melhor" (5.23), sendo que, explicitamente, a palavra morte não chegou a ser verbalizada. Entretanto, a associação da tuberculose à morte revelou-se nos relatos, como pode ser verificado a seguir:

- "A doençalth incorpora a noção e a sensação de morte e provoca 'medo'” (7.6)

- "A doença/tb provoca sentimento de morte, que é superado pela 'força pessoal"” (4.6)

-"A complexidade da doença, enquanto passivel de morte, provoca sentimento de 'medo'”' (3.5)

Ao mesmo tempo, emergiram as seguintes representações: "a concepção de que a vida existe fora do plano terrestre relativiza a noção de vida e de saúde" (14.47) e "a vida é originada do divino e só este detém o poder de tirá-la" (14.57). Ora, ao que parece, as reflexões aqui colocadas imputam a questão da vida a um plano superior do 
qual a pessoa se alija, isto é, parece não ter possibilidade de interferir, o que de certa forma recupera a concepção divina da vida, alicerçada no pensamento religioso que impregna a interpretação do processo saúde-doença ao longo dos tempos. Coloca ainda em relevo uma outra face que expõe a fragilidade da vida e, portanto, a relativização da doença, em função de uma visão mística/transcendental. HELLER (1991) explica que a religião constitui-se como uma representação coletiva baseada na dependência do ser humano em relação ao transcedental. Defende que a religião é um fenômeno de alienação e que a forma mais corrente dessa alienação é a idéia da dependência do transcedental. Exemplifica que as ações dos individuos estão dirigidas, encaminhadas ou influenciadas por "potências transcedentais" ou seja, tudo sucede por vontade de Deus, ou dos deuses. O ser humano atua livremente, mas no âmbito de possibilidades estabelecidas na transcendência. É interessante notar ainda a forma como a autora encaminha o raciocínio em relação à dependência do ser humano em relação ao transcendente, ao argumentar que não existe nenhuma religião que saiba representar a sua divindade segundo uma forma diferente que a não humana, ou seja, com paixões humanas. Por essa razão projeta-se sobre a divindade as reações e perspectivas do humano. Assim, as capacidades do ser humano são prolongadas e universalizadas na divindade, como por exemplo, a liberdade, a onipotência, bem como outras aspirações particulares.

A autora coloca que ainda que em última instância, o tipo e o ritmo de vida estão regulados pela atividade econômica, a religião constitui-se como um dos mais importantes organizadores e reguladores da vida cotidiana, ao conferir à vida uma determinada forma. Assim, a religião codifica e controla o respeito aos deveres familiares e estende seu poder à higiene e à vida sexual. Dessa forma, viver sob determinada religião significa não somente crer ou admitir os dogmas máximos mas, ao mesmo tempo, orientar o modo de vida segundo as exigências e as formas daquela religião. Acrescenta ainda que a religião não é único fator que organiza a vida cotidiana, que lhe dá forma, pois há ainda o denominado "mito laico", ou seja, o sistema de superstições derivadas da fé primitiva, além dos códigos morais e o sistema jurídico estatal que "se intrometem", segundo a autora, na vida cotidiana dos homens. Daí então a explicação da forma como o doente constrói a representação da saúde, da doença e da vida, as quais estão permeadas pelo conteúdo transcedental. 
Apesar de que a maioria dos conceitos que emergiram no presente estudo remetem à uma idéia negativa da doença, há que lembrar que no decorrer do século XIX, a tuberculose era doença "desejada", uma vez que traduzia todo um modo de comportamento e de estar no mundo (CORTEJOSO, 1943). A manifestação desse comportamento indicava uma atitude de rebelação contra a ordem social existente, o que fazia com que determinadas pessoas ansiassem por ser por ela acometidos.

Por outro lado, o conteúdo de caráter essencialmente moralista, que se constitui em grande parte em legado do pensamento judaico-cristão nas sociedades ocidentais (LITTLE, 1995), também se revelou nos depoimentos do presente estudo, corroborando o que historicamente tem sido imputado à doença, ou seja, de que a tuberculose se "conforma como uma lição" (11.16). HELLER (1991) coloca que o efeito da moral é exercido quando a exigência é interiorizada, quando é elevada à motivação pessoal, isto é, quando a exigência da sociedade aparece como uma exigência que o indivíduo dirige a si mesmo. Argumenta ainda que o esquema base da moral é a subordinação das necessidades, dos desejos, das aspirações particulares às exigências sociais, as quais obstaculizam o desenvolvimento da individualidade, impedindo que o indivíduo veja-se no coletivo. CRAWFORD (1980) defende que a saúde e a doença são conceitos eminentemente morais e não podem ser entendidos independentemente dos princípios morais predominantes em determinado momento histórico, nem das relações sociais que ali têm lugar e, dentre elas, a relação médico-doente.

Verificou-se ainda que "a doença/tb acomete os 'disciplinados' $e$ isso causa inconformismo" (7.22); "há inconformismo/impotência diante da realidade: cuidado com a saúde x aquisição da doença" (4.33); "a doença ocorre quando a vida começa a ser 'disciplinada' e isso provoca 'surpresa' (15.16), estando presente também a aparente ausência de associação entre o ter saúde e a regularidade e disciplina na vida (1.21). Essas frases evidenciam um sentimento de frustração e decepção, na medida em que, mesmo buscando seguir os comportamentos tidos como "normais", "disciplinados" ou "regulares", de certa forma impostos pela sociedade, assim mesmo, o organismo é "castigado" pela doença: "O diagnóstico é tomado como 'normal', apesar do doente 'ficar chateado' e reflete um conjunto de atitudes 'desregradas' (tomar chuva, 'ter noitada')" (9.11). E, ainda: “o comportamento 'bom' e a 'disciplina' não levam à 
doença (14.52), o que traz à tona a representação da enfermidade como secundária a hábitos, condutas e atitudes que fugiriam ao que a sociedade imprime como "regras do bem viver". BERTOLOZZI (1991) argumenta que, ao revelar-se a tuberculose como "ordenadora" da vida, teria um sentido de reconstituir a existência com base no que a sociedade imprime como disciplina e moral. Segundo BERLINGUER (1980), a difusão da idéia de que certos estilos de vida podem levar ao adoecimento, traz à tona o estatuto de que a "cumplicidade" do paciente com os estilos de vida denominados como deletérios, permitiria ao Estado reduzir a assistência à saúde.

HELLER (1991) explica que as regras ou normas são exigências criadas pela sociedade as quais, uma vez interiorizadas pelo indivíduo, fazem com que a obrigação se transforme em dever. A autora defende que o mundo apresenta inúmeras regras de comportamento e que a simples observação dessas regras é uma prescrição que o meio social dirige a cada indivíduo. Coloca ainda que as regras de comportamento na vida cotidiana são concretas e precrevem com relativa exatidão o que se deve ou não fazer.

Ora, as representações encontradas no presente estudo reproduzem a ideologia da saúde como um bem que se obtém a partir da adoção de determinadas atitudes/comportamentos tomados pelo sujeito particular. Não colocam em relevo a raiz do aparecimento da tuberculose, mas põem em evidência o caráter individual e moral que permeiam a enfermidade. Nessa mesma linha, tanto a linguagem da auto-ajuda, da responsabilidade individual, entre outras, que amparam essa concepção obscurecem as relações de poder que subjazem à produção social da doença (CRAWFORD, 1980).

Destaca-se ainda o fato de que não só a doença recebe qualificativos por parte do doente, mas também dos familiares que o acompanham e, em geral, essas representações estão permeadas por cunho negativo, tal como para os entrevistados: "A doença/tb é interpretada como ... 'coisa feia'e 'difícil', pelos familiares do doente" (14.17).

Na mesma linha que pôde ser verificada anteriormente, ou seja, da conotação de processo "dificil', vale observar a presença de um outro conceito que marca a representação da tuberculose: a complexidade, a partir da perspectiva do órgão que a doença acomete. o pulmão. que é "considerado o segundo órgão vital, depois do 
coração" (15.25). Existe, portanto, no imaginário do doente, uma relação entre a complexidade da enfermidade e o órgão acometido.

A noção de gravidade da doença somente se revela a partir do momento em que os sinais e sintomas começam a se manifestar (13.5), existindo uma oscilação entre a percepção da tuberculose como doença grave/não grave, complexa/ não complexa (7.7). De fato, para alguns ela é concebida como "um processo complexo ('não é ter uma gripe, um sarampo ') " (7.7), concepção que parece estar atrelada à possibilidade ou não da cura (17.19). Sendo passível de cura, a tuberculose é concebida como não grave (12.8), ao contrário da AIDS, que se revelou em muitos depoimentos como doença "considerada pior que a tuberculose, pois não tem cura"(17.18).

Além da manifestação de alguns sinais e sintomas que seriam o código para determinar tanto a situação de doença, como a necessidade da busca da assistência médica, a magnitude da enfermidade é evidenciada pela observação da radiografia (2.12), como se para o doente fồsse necessária a constatação visual da tuberculose para a compreensão da sua complexidade.

Há que se enfatizar, conforme anteriormente colocado, que as representações sobre a doença expressam a forma como as pessoas, a partir de sua inserção na sociedade, percebem o processo mórbido. Na verdade. as formas como são construídas a cultura, o saber, os olhares e interpretações sobre a saúde-doença, bem como as intervenções sobre esse processo, relacionam-se dialeticamente com o modo como o homem produz a sua própria existência e como se constitui histórica e socialmente. Assim, não é possivel analisar as suas opiniões apenas como adjetivos, mas como um reflexo da posição das pessoas frente ao mundo, o que inclui também seus valores relacionados ao campo da saúde, além da noção dos direitos que possuem enquanto cidadãos (MANDÚ. 1995).

CHAMMÉ (1994) identifica que os comportamentos de saúde-doença são adotados segundo os elementos culturais que fazem parte do contexto onde os grupos sociais participam, elementos esses que seriam identificados, experimentados e 
intercambiados entre os sujeitos sociais. O significado dado à saúde e à doença reflete as experiências dos grupos, bem como as suas relações com o cotidiano.

Em continuidade à interpretação do universo de representações sobre o processo saúde-doença, verificou-se que as concepções sobre a tuberculose via de regra estão permeadas pela associação da doença a sinais e sintomas e/ou outras doenças. Assim, observou-se que ainda que a tuberculose se constitua em enfermidade aparentemente conhecida, uma vez que está presente na humanidade há milhares de anos, no presente estudo, de modo geral, a "sintomatologia inicial não é associada à tuberculose", mas à gripe $(4.3,8.1)$, amigdalite $(4.3)$, resfriado $(9.3,15.1)$, pneumonia $(12.2)$, problemas na tireóide $(4.3)$ ou à doença renal $(11.1,16.1)$. Quando a sintomatologia é associada à tuberculose, o processo saúde-doença é desencadeado por outra enfermidade, tal como a bronquite (1.1), sendo que a conexão com a tuberculose foi fruto da lembrança de membro da família que já havia acompanhado a doença de uma outra pessoa (16.4).

Por outro lado, mesmo que a doença já tivesse ocorrido na familia, o conjunto de sinais e sintomas nem sempre determina que as pessoas percebam como se constitui a tuberculose (9.5), o que é digno de menção, uma vez que evidencia que a sintomatologia é decodificada de forma particular, mesmo para pessoas que supostamente participariam da vida familiar e que, seria de se esperar, adotariam os mesmos símbolos que o doente para representar a doença.

De qualquer forma, o "estado" de doente, ou seja, o momento que a pessoa se percebe doente, emerge por ocasião da manifestação de sinais e sintomas $(2.3 ; 3.1 ; 9.6)$ isolados ou agregados, interpretados como algo inusual, não rotineiro, sendo que os signos por excelência que a caracterizam são a dor (5.36) e o aparecimento súbito de febre alta (2.2).

O abatimento, acompanhado pelo emagrecimento, foram tomados como manifestação da doença por alguns $(9.11 ; 16.6)$ e não para outros $(2.14)$, verificando-se ainda que a ausência da doença está "associada ao acesso diferenciado à alimentação" (5.26). Na mesma linha, há uma concepção de que a saúde depende de alimentação "adequada ('não forte, sem frituras')" (4.34). Este achado, que valoriza ora a a 
interpretação da saúde-doença a partir da unicausalidade, ora a partir da multicausalidade, também foi revelado no estudo realizado pela pesquisadora no Município de Taboão da Serra (BERTOLOZZI, 1991).

Destaca-se ainda que o emagrecimento apareceu em alguns relatos como "sinal de perigo/gravidade para a doença e provoca pavor"(5.16), evidenciando-se a probabilidade da associação de idéias entre a tuberculose e a perda de peso $(11.11 ; 16.6)$ e de apetite (16.6), apesar de que houve referência também ao fato de que: "o início da doença/tb não foi acompanhado por diminuição do apetite” (2.1). Mas é necessário apontar que esse estado particular, apreendido como definhamento não provoca o mesmo sentimento para todos, uma vez que verificou-se que: "a sintomatologia debilitante não provoca "abatimento" (14.5), o que significa que os sintomas provocados pela tuberculose nem sempre provocam diminuição da disposição.

RUBEL e GARRO (1992) ao estudarem aspectos antropológicos e culturais relacionados à tuberculose, em determinadas sociedades hispânicas na atualidade, verificaram que as pessoas ainda atribuem à doença um caráter de consumpção e, ao mesmo tempo conservam o preconceito em relação à enfermidade, uma vez que após o período de hospitalização, as famílias não permitem que os doentes regressem ao lar.

Algumas representações do presente estudo revelam que a materialização da enfermidade somente começa a se revelar a partir do momento em que o doente apresenta o escarro hemóptico, manifestação que causa "preocupação" (2.20) e "medo" (9.10), porque é um sinal "anormal" , ao contrário dos demais sinais e sintomas (5.7). O sentimento de medo também está presente pelo fato de que " $a$ primeira doença a ser pensada é a AIDS" (9.10). Assim é que, mais uma vez, vale dizer que ainda que alguns sinais e sintomas sejam mais ou menos conhecidos e identificados como tuberculose pelo senso comum, há outros que definem verdadeiramente a presença de doença e estes, via de regra, representam situações-limite ou emergenciais, como a presença de hemoptise, por exemplo.

Uma outra característica que se evidencia sobre a enfermidade é a de que ela, para alguns, "provoca dor" (17.17) enquanto que para outros "o signo da enfermidade 
não se configura como doença/tuberculose devido ao seu caráter silencioso ("sem dor")" (5.35). Ou seja, faz parte também do universo de representações sobre as doenças, de modo geral, a idéia de que se evidenciam através da dor. Sobre essa questão vale a pena proceder a uma interpretação cuidadosa, na medida em que algumas enfermidades se desenvolvem em algumas fases aparentemente sem manifestações e no caso de certas doenças transmissíveis (hepatites crônicas virais, AIDS, sífilis), isto pode vir a resultar em disseminação inconsciente da doença contribuindo para a sua difusão junto à coletividade.

Ainda é importante destacar que esse suposto "silêncio" da tuberculose, ou a presença de queixas inespecíficas, caracterizadas nas representações pela ausência de dor, podem determinar o “'descaso' do doente” (5.37) na busca de assistência pois, segundo ele, não há um motivo aparente que justifique tal atitude. Além dessa representação, “a vulgarização dos sintomas, os quais são tomados inicialmente como 'uma gripe'” $(4.4 ; 15.5)$ determina uma atitude de falta de importância em relação à doença que resulta no seu tratamento no âmbito doméstico. A sintomatologia não chegaria a atingir uma complexidade tal que justificasse a necessidade de busca de assistência médica, resultando com que o doente faça uso de "medicamentos caseiros, sob a forma de "chás" (10.2), "xarope" (4.4), "controlada por auto-medicação com o uso de analgésicos/antipiréticos, como aspirina/novalgina (15.1)". De fato, inicialmente, a tuberculose apresenta-se como uma "gripe": "o cortejo sintomático é compativel com o de uma doença infecciosa, de curso geralmente crônico, no qual se destacam febre, perda de peso, astenia e, em sua forma clínica mais prevalente, tosse com expectoração que pode evoluir para escarros sangüíneos e hemoptise" (MINISTÉRIO DA SAÚDE, 1994b).

A concepção da doença carrega em sua interioridade uma representação "padrão" que parece impregnar o modo de pensar: "para o doente, o encadeamento doença-tratamento-cura tem um "padrão", considerado "normal" (1.4). E, dessa forma, a "manutenção da sintomatologia é considerada anormal pois rompe com o processo doença-tratamento-cura" (1.5). Na realidade, esse padrão reproduz a forma como a medicina concebe a doença, ao "elaborar leis generalizantes explicativas do objeto de conhecimento sem referência histórica: o corpo anátomo-fisiológico tornou-se 
assim um campo de invariantes qualitativas no qual é possível explicar, para todas as situações históricas concretas, a ocorrência da normalidade e da patologia" (MENDESGONÇALVES, 1994). E essa forma de representar a doença através de um padrão, na verdade, é apoiada pelo paradigma racional doença-cura que permeia as relações de trabalho na saúde e é operacionalizado sistematicamente pelos trabalhadores da saúde e assim apreendido pelos doentes. Essa concepção teórico-prática sustenta um olhar sobre o indivíduo desvinculado da relação dinâmica com a natureza e com a sociedade e referese imediatamente à ótica da doença (CRAWFORD, 1980; KANTORSKI, 1997).

É evidente que não se trata aqui de desconsiderar o conjunto de sinais e sintomas, deixando de proceder a uma interpretação que conduza a um dado diagnóstico. No caso da tuberculose é bastante claro o padrão com que se apresenta a sintomatologia, entretanto, o que se está querendo apontar é o fato de que o raciocínio clínico está voltado diretamente para a dimensão biológica, não dando lugar em algumas ocasiões a informações que totalizariam a compreensão sobre o processo saúde-doença. E essa forma de interpretar a doença é apreendida e reproduzida pelo coletivo que, de igual maneira, passa a entendê-la sob uma perspectiva linear e invariante.

Para MENDES-GONÇALVES (1979) essa lógica de pensamento está fundada na concepção da individualidade intrínseca dos fenômenos, isto é, a saúde e a doença são colocadas pela medicina como situações que dizem respeito ao homem. indivíduobiológico, independentemente de outras determinações e indiferentemente às características peculiares dos grupos sociais. Ao ser diagnosticada, a doença reduz o homem concreto ao indivíduo universalizado e à condição de ser humano genérico, sem outras adjetivações senão essa que lhe é aposta pela medicina. Ao individualizar o normal e o patológico no nível do corpo do homem individual e estritamente biológico, a clínica leva à "ruptura das conexões desse homem consigo mesmo". Como resultado, há uma concepção de saúde e de doença como fatos que seguem um padrão e que estariam inteiramente contidos nos limites da fisica, química e biologia do corpo humano (MENDES-GONÇALVES, 1994). Essa concepção deixaria de lado aspectos fundamentalmente importantes como aqueles relacionados à questão social, ou seja, que se referem à doença como um produto de um certo modo de trabalhar e de viver. 
Ainda, essa representação da doença tem suas bases assentadas nos fundamentos platônicos, que a conformam a partir de um padrão perfeito. E a lógica de concepção e de entendimento é sobretudo probabilística no que se refere à forma como o trabalhador de saúde constrói a causalidade e a terapêutica, na medida em que são procurados achados anormais para categorizar e estagiar a doença, em função de atributos como local, extensão do órgão acometido, além de sua consistência, mobilidade, temperatura, entre outros (LITTLE, 1995). A objetividade dos atributos é interpretada à luz de modelos estocásticos, sendo que questões que dizem respeito à dimensão social não encontram continente explicativo, evidenciando-se assim a sua insuficiência teórica.

Reproduzindo os modelos explicativos que tradicionalmente são aplicados pela medicina, verificou-se que para o doente: “o processo saúde-doença está dividido em dois momentos: normal (desempenho das atividades do cotidiano e do trabalho) $e$ doença (inicio da sintomatologia)" (1.7). Ora, o conteúdo dessa frase temática introduz um elemento importante para a análise, na medida em que evidencia que o referencial para a saúde é o trabalho, representado pela capacidade de poder desenvolver as atividades para a manutenção da reprodução social, enquanto que a doença seria justamente o contrário, ou seja, a suspensão ou paralisação desse processo devido à emergência dos sinais e sintomas.

Ainda que a doença se expresse como um fenômeno "anormal", há um movimento para considerá-lo como "normal" ("pega até num ônibus") (12.14), na medida em que essa atitude determinaria "diminuição da ansiedade do doente" (12.14) e: “ a doença/tb, apesar de ter-se constituído em problema em época antiga, hoje é tomada como normal/regular ('não é nada do outro mundo') (6.18). Possivelmente essa representação tem embutida a necessidade de tornar a doença um fato não individual, personalizado, não dependente de associações a determinadas características do ser humano, sejam elas de ordem biológica ou social. Antes, traduziria um movimento para tornar a doença um fato comum à coletividade, na tentativa de negar a própria situação de não higidez biológica ou das condições particulares de vida. Um outro aspecto que deve ser levado em conta é que a representação pode sofrer mudanças na medida em que o doente passa a elaborar a doença como um processo que faz parte de seu cotidiano, ou seja, a partir da vivência da doença. 
Cabe aqui destacar ainda o fato de que contrair a doença determina com que o indivíduo perceba a fragilidade do organismo (17.27). É como se o processo de "atenção" para com o próprio corpo somente tivesse início a partir do momento em que a pessoa constata a limitação ou a incapacidade para o desempenho das atividades de rotina, passando então a incorporar o "estado de enfermo".

$\mathrm{O}$ aparecimento de sintomatologia provoca a emergência de sentimentos como “ 'ansiedade e medo', uma vez que indica a presença de doença/tuberculose e a potencial necessidade de interrupção das atividades relacionadas ao trabalho" (8.2). Ou seja, mais uma vez, o conjunto de sinais e sintomas conformam para o doente uma entidade - a doença - que provoca a evidenciação de sentimentos "negativos", não pela doença propriamente dita, mas pela forma como ela pode impedir ou limitar o desenvolvimento das atividades relacionadas ao trabalho. A perda maior, nesse caso, não se refere ao fato de apresentar-se doente, mas das repercussões que isto pode vir a ter no âmbito do trabalho, o que significaria a potencial paralisação das atividades. $\mathrm{O}$ trabalho adquire, portanto, um significado ainda mais amplo e profundo do que perceber-se acometido pela doença. Nesse momento, não importa o corpo singular, mas a limitação que pode advir da doença no desempenho para o trabalho, que é justificada no âmbito do capitalismo, na medida em que o corpo humano tem um significado social como força de trabalho.

O trabalho constitui-se em referência tanto para a recordação do início da doença (10.1), como na medida em que seu excesso, ou a execução de certas atividades determinariam o aparecimento do processo mórbido $(5.26 ; 12.16 ; 14.1 ; 17.4)$. E, reforçando o exposto, "a continuidade do trabalho e a ausência de sintomatologia (após o tratamento) constituem ausência de doençátuberculose" (10.7).

É fundamental apontar que o trabalho assume status de referencial, na medida em que representa o uso do corpo, tanto para a produção como para a reprodução social, ou seja, para a manutenção do cotidiano. A emergência da doença "provoca choque/depressão, ocasionada por interrupção do trabalho (demissão)" (4.10). 
Verificou-se ainda uma outra dimensão na relação doença-trabalho: “o doente supõe que o diagnóstico determine que o empregador o demitalafaste do trabalho" (1.22), o que mais uma vez coloca em evidência a representação da doença como obstáculo ao desempenho da atividade laboral. Parece, inclusive que se altera a ordem de determinações pois, ao invés do paciente presumir que, possivelmente, o processo de trabalho desencadeou a doença, esta é que passará a determinar repercussões sobre o mesmo.

$\mathrm{Na}$ medida em que o trabalho emerge como uma questão articulada às representações sobre a doença, tanto no que se refere à sua causalidade, como em termos das mudanças que esta imputa ao cotidiano, é fundamental proceder a algumas reflexões. $O$ trabalho não se constituiu, na verdade, em uma categoria analítica no presente estudo, mas não deixa de ser central, na medida em que envolve a interpretação dos diversos modos como o homem se constitui objetiva e subjetivamente na vida. Segundo HELLER (1991), o trabalho é necessário para a reprodução social e é o elemento dominante na vida cotidiana, já que em torno dele estão organizadas as atividades da vida cotidiana. Além disso, o objetivo do trabalho é produzir, direta ou indiretamente, valor de uso, isto é, meios e objetos para a satisfação das necessidades de consumo ou de produção. Destaca que o movimento na vida cotidiana se dá segundo regulações ou ordens constituídas pelos sistemas sociais gerais ou particulares que fixam determinadas formas de ação e, em certa medida, o ritmo de vida. Assim. o regulador de fundo da vida não é o uso, mas o lugar ocupado pelo indivíduo na divisão social do trabalho.

KANTORSKI (1997) destaca algumas dimensões do trabalho como categoria analítica na abordagem do processo saúde-doença. A primeira delas se refere ao fato de que o trabalho consiste em uma condição inexorável da existência humana, tendo um papel fundamental no seu processo antropogenético. Não se pode, portanto, falar do humano desvinculando-o da sua atividade material transformadora. É nesse sentido que também não é possivel desarticular, por um lado, as repercussões da doença sobre o trabalho e nem mesmo analisar essa questão, desvinculando-a do corpo de conhecimentos que a teoria da determinação social da saúde-doença coloca para a interpretação da causação desse processo. 
A mesma autora ainda faz referência a uma outra dimensão do trabalho que deve ser verificada, na sua perspectiva de gerador de relações sociais pois, ao garantir os meios necessários para a sua sobrevivência através do trabalho, o homem estabelece relações sociais com outros homens, possibilitando a convivência coletiva. Essas relações sociais de produção, por sua vez, geram possibilidades de troca e espaços para compartilhar desejos e projetos entre os homens. Na medida em que a doença obstaculiza o desenvolvimento do trabalho, rompem-se as possibilidades para que estas últimas se efetivem, o que explicaria, portanto, os processos e os sentimentos que se produzem no imaginário dos doentes, em função da enfermidade.

Uma outra dimensão refere-se ao fato de que o trabalho é fundamental para a criação da identidade do homem. Ou seja, ao trabalhar, o homem produz a sua identidade social, “... no produto do trabalho, situando-se no espaço da produção e constituindo-se como sujeito coletivo de seu próprio projeto existencial". É evidente que esse estatuto não deve ser visto de forma reificada pois, no modo capitalista de produção e em continuidade, sob o neoliberalismo, o trabalho não objetiva o desenvolvimento das potencialidades humanas, nem a satisfação, tampouco o prazer. Para MARX (1982) o trabalho não é a satisfação de uma necessidade, mas somente um meio para satisfazê-las. Assim, sob a égide do modo de produção anteriormente mencionado, o trabalho significa um meio para a consecução das necessidades de sobrevivência e de consumo, as quais serão diferentes segundo as distintas inserções no sistema de produção. Assim, o alijamento do doente em relação ao trabalho, ainda que momentaneamente, significa na paradoxal inviabilização das dimensões anteriormente mencionadas.

Ainda um ponto fundamental que deve ser ressaltado, refere-se ao fato de que a opção econômica por esse determinado modo de produção acaba por introduzir novas formas de trabalho, de relações sociais, de identidade humana, que também produzem novas subjetividades e novos modos de viver e de interpretar a vida, que devem ser consideradas ao analisar a saúde-doença como um processo e, mais especificamente a questão atual da adesão dos doentes ao tratamento da tuberculose. A emergência dessas relações sociais vai imprimir um significado distinto da força de trabalho, das necessidades dos sujeitos, bem como das relações técnicas e sociais de produção na área 
da saúde, as quais muitas vezes têm sido desconsideradas quando se analisam as representações dos doentes, assim como o seu comportamento em relação à doença.

Continuando a recuperar o conjunto de frases temáticas, primeiramente no que se refere à concepção da doença, verificou-se que o conhecimento sobre o diagnóstico da tuberculose, segundo menção dos entrevistados, provoca sentimentos que foram expressos como: "abalo" (1.9; 11.12); "desorientação" (12.13), "mal estar" (4.14; 5.12), “tristeza"(6.6), "susto" (8.9), “nervosismo" (10.11; 16.3), “medo" (15.4; 16.3), “preocupação" (16.3), "apreensão" (17.8), sendo que a revelação do diagnóstico parece ser considerada como o momento mais grave da evolução do processo saúdedoença (2.16). E essa é uma constatação relevante pois, via de regra, nos serviços de saúde, não há uma forma para lidar com essa questão que seja mais apropriada às necessidades dos doentes. $\mathrm{Na}$ medida em que essas necessidades não são expressas efetivamente pelo doente, ou são expressas mas não decodificadas como necessidades pela equipe de saúde, passam ao largo do processo da terapêutica, repercutindo evidentemente, tanto na "aceitação" da doença, ou seja, sua elaboração como um componente a lidar em sua vida, como na própria adesão ao tratamento. Facilitar essa elaboração é tarefa dos trabalhadores de saúde, que devem buscar entender o significado da doença para a pessoa, não reduzindo a enfermidade a sinais e sintomas, mas interpretando-a como um conjunto de manifestações que, no caso da tuberculose, se devem a determinadas formas de trabalhar e de viver que podem favorecer $o$ desenvolvimento da enfermidade.

Ora, os sentimentos anteriormente mencionados emergem pelo fato de que a doença determina o afastamento (físico e de objetos) dos familiares (6.6), do trabalho (1.22), e das repercussões que isto pode causar, como por exemplo, o "desabastecimento de alimentação para a familia" (6.6), ou ainda devido ao próprio desconhecimento da doença e do que pode dela advir (8.9) ou de sua causa (10.11) ou pela necessidade de internação (15.4).

Como pode ser visto pelo conteúdo representacional das frases temáticas apontadas, a tuberculose realmente envolve questões amplas e que permanecem por vezes intocadas pelos serviços de saúde, sob a argumentação de que não seriam objeto 
de sua prática. Além disso, apesar de tantos anos decorridos, tanto da descoberta do agente etiológico causador da doença, como das drogas para o seu controle, e mesmo do uso da vacina, ainda se faz presente a questão relativa ao isolamento que pode trazer a doença e que é pouco trabalhada na assistência à saúde. Não é possível assim, banalizar a doença sob a alegação de que acompanha a humanidade desde os tempos antigos, ou porque é passível de cura, mas pelo próprio fato de ser a tuberculose doença de cunho eminentemente social, há que buscar compreender esses processos, desvelando-os e amparando as necessidades do doente e da coletividade que, como pode ser visto, vão além das fronteiras que tradicionalmente a clínica tem colocado, mas se referem à: "noção de contagiosidade, de afastamento, de isolamento, de discriminação" (17.8), uma vez que esses conceitos são verbalizados pelos depoentes, mas muitas permanecendo intocados pelos profissionais de saúde.

Entretanto, da mesma forma em que o diagnóstico provoca a assunção desses sentimentos, a 'ausência de diagnóstico também 'causa preocupação', maior do que a relacionada à doença propriamente dita" (14.30), uma vez que revela um desconhecido sobre o que está se processando no próprio corpo. Nessas situações, a revelação do diagnóstico, ainda que sendo um processo doloroso, é menos conflitante do que a sua ausência, o que evidencia o temor pelo que está ocorrendo com o corpo. Há necessidade de um código, ou seja, de que a sintomatologia seja decodificada e interpretada de alguma forma. Dessa forma, ainda que parecendo paradoxal, verificaram-se representações "positivas", como aquelas em que o esclarecimento do diagnóstico de tuberculose provocou "alívio" (2.13), “contentamento" (14.44), "fortalecendo o projeto de querer viver" (2.45).

Verificou-se também que "as medidas para a diminuição da transmissão da doença (ventilação do domicílio) provocam "pavor e medo da morte" (5.22) e, “o diagnóstico de luberculose e as medidas de precaução utilizadas no hospital (uso de máscaras) provocam 'mal estar' emocional (5.12); o que evidencia que não só o diagnóstico atemoriza a pessoa, mas também a forma como se lida com a doença. Apesar de décadas terem se passado do início do uso dos quimioterápicos para o tratamento da doença, ela ainda é permeada pelo preconceito e pela discriminação. 
HELLER (1970) afirma que o preconceito é fruto da própria integração social e que serve para consolidar e manter a estabilidade e a coesão dessa integração. Na medida em que caracteriza-se por uma tomada de posição moral, destaca-se a importância do significado das representações acima mencionadas, pois muitas vezes, no cotidiano do trabalho no interior dos serviços de saúde, essas questões são negligenciadas, sem que se perceba o impacto que pode causar ao doente a prescrição de medidas relacionadas ao controle da transmissão da enfermidade, ou os procedimentos utilizados no âmbito hospitalar. Quando essas ações são arroladas pelo profissional de saúde, solicita-se que sejam cumpridas pelo doente, sem que se avalie qual a repercussão de sua aplicação no dia a dia da pessoa, desconhecendo o significado que tem para ela, como pode se verificar através da frase seguinte: "o cumprimento de ordens médicas (uso de objetos descartáveis) provoca 'abalo' e estigmatização (5.21).

Ora, a redução da consulta médica à série de procedimentos que incluem o exame físico, a anamnese, a elaboração do diagnóstico e a terapêutica nem sempre parece proporcionar o espaço necessário para que o doente verbalize tais sentimentos, carência essa que pode resultar no debilitamento da adesão ao tratamento. Além disso, os outros espaços em que o doente supostamente teria acesso no serviço de saúde, fora do âmbito da consulta médica, de igual maneira parecem não dar conta de captar essas questões, o que potencializa as limitações do serviço de saúde no controle da enfermidade, uma vez que historicamente trabalha prevalentemente com questões que são tidas como objetivas, pois integram o arcabouço que a medicina prevê para a doença, ou seja, essencialmente clínica e biológica, numa dimensão reducionista da doença, determinando que as intervenções desenvolvam-se segundo uma perspectiva mecanicista (LITTLE, 1995). Aqui vale comentar o fato de que, a evolução rápida e desejada do conhecimento científico não tem determinado um concomitante desenvolvimento das relações, tanto no trabalho em saúde, como com o doente que levem à emancipação do humano, com vistas à consecução da eqüidade social.

NETTO e CARVALHO (1996) procedem a uma análise que recupera a especificidade do trabalho no campo do social que poderia aqui embasar a discussão. Argumentam que o profissional que atua nesse campo trabalha com duas contradições: a 
do usuário dos serviços do Estado e a satisfação de necessidades. Contradições pois o doente nesse caso é o usuário e não o cidadão uma vez que tem em geral a sua cidadania destituída pela própria condição de ser doente, e que busca satisfazer suas necessidades, o que já comporta uma contradição intrínseca. Por outro lado, os processos de trabalho na saúde fragmentam o ser, como se o indivíduo fosse um somatório de necessidades a serem satisfeitas.

Ilustrativo do que foi anteriormente dito pode ser visto na frase temática seguinte, que traz à tona a importância de uma relação diferenciada (que deveria ser usual nos serviços de saúde) entre o profissional de saúde e o doente e que acarreta para este último em uma outra forma de se relacionar com a doença e com aqueles com os quais convive: "Compartilhar a doença com o profissional médico determina a diminuição do afastamento do doente em relação à outras pessoas" (13.15).

Um outro aspecto que vale destacar de frase anteriormente mencionada que se refere ao uso de objetos descartáveis pelo doente, é que isso evidencia um equivoco, ainda presente, preconizado por alguns profissionais de saúde que parecem desconhecer a abolição desse tipo de medidas. Na verdade, há evidências de que duas semanas de quimioterapia continuada determinam uma diminuição muito acentuada da transmissão da doença (JOHNSTON e WILDRICK, 1974). Evidentemente que a ausência de fundamento para a adoção das ações para a não disseminação da doença, somente contribuem para aprofundar o sentimento de preconceito que permeia a doença, além de não concorrer para o controle efetivo da enfermidade.

Ainda com referência à questão do preconceito que a doença carreia, verificou-se que este também se materializa através da seguinte atitude: "a doença/tb não é divulgada" (17.31) pelo doente, sendo que, em geral, o processo saúde-doença é vivenciado exclusivamente no interior do núcleo familiar $(6.15,18.13)$. Quando muito, "a doençaltb é divulgada somente para algumas pessoas mais próximas do círculo de convívio (potencialmente capazes de apoiar)" (3.16, 13.13). E isso ocorre, possivelmente pelo sentimento ou atitudes que a doença pode vir a desencadear: " $a$ doença/tb não é divulgada desde o inicio para os amigos devido a 'receio' (2.28, 12.17) por causar 'preconceito/incompreensão/pena'” (12.17). 
Esse mecanismo de não divulgação da doença a outros seria aplicado, segundo GOFFMAN (1982), como um esforço do doente para que a enfermidade não se revele, buscando assim a diminuição da tensão e tornando mais fácil para si mesmo e para os outros, através de uma redução dissimulada do estigma, pela manutenção de um envolvimento, ainda que mínimo, na interação com outros. Entretanto, nem todos se comportam de igual maneira, ao deixar de revelar ser portador da doença, uma vez que algumas pessoas relataram informar o fato aos colegas de trabalho: "A doença/tb $e$ divulgada no ambiente de trabalho" $(8.12,15.8)$.

Um aspecto bastante importante é o fato de que algumas pessoas preferem referir-se à doença, não como tuberculose, mas por outras enfermidades, como por exemplo, a pneumonia, que parece assumir uma conotação diferente no âmbito da coletividade, possivelmente porque não é permeada pelo preconceito que a primeira historicamente tem carreado: "a doença/tb é divulgada sob a forma de 'pneumonia'"(7.10).

Vale a pena ainda ressaltar um outro aspecto interessante, que se refere ao fato de que a diferenciação geográfica, antes do que a cultural, é apontada como uma possibilidade de visualizar/compreender diferentemente a doença. A doente que abordou essa questão fazia referência à população do sul do país que, segundo ela, trataria a tuberculose de uma forma mais preconceituosa que na região onde vive atualmente (São Paulo): “O preconceito/discriminação dependem da cultura da região geográfica onde se vive" (4.20).

Destaca-se ainda que o estigma não se revela somente da perspectiva da coletividade para com o doente, mas a relação inversa também parece ser verdadeira: "existe preconceito/estigma do doente em relação aos outros $(6.19,7.11)$ e dos outros em relação ao doente $(5.40,6.19,7.11)$. O preconceito que emerge do doente evidentemente tem raiz diferente daquela que se configura por parte da coletividade. Em decorrência da enfermidade, o doente passa a assumir atitudes de afastamento, possivelmente para evitar entrar em confronto com uma questão que para ele mesmo é dificil de se equacionada e incorporada no cotidiano. 
Verificou-se ainda que a doença determinou "maior solidariedade com familiares e amigos" (2.25), "maior atenção/recomendações por parte dos familiares para com o doente" (13.10), "a doença/tb determina a mudança da percepção do doente em relação ao valor das pessoas" (10.20), "a melhora do relacionamento com as pessoas e a desvalorização de aspectos materiais" (14.53) e ajudou a evidenciar em que medida se pode efetivamente contar com outras pessoas no cotidiano: " $a$ doença/tb faz constatar sobre a real possibilidade de ajuda dos amigos (limitada ou ausente)" (2.27), determinando, em conseqüência, “o 'fechamento' no relacionamento com os amigos" (2.29), isto é, limitações no relacionamento com as pessoas de seu convívio.

Há assim, um movimento que se concretiza na mudança de comportamentos e atitudes do doente para com as pessoas e destas para com ele, o que evidencia que o processo saúde-doença não tem apenas cunho individual, mas se refere a uma dimensão maior que incorpora uma rede de relações humanas. Isso tem um significado importante pois a adesão também parece estar intimamente ligada à forma como essas "outras pessoas" que convivem com o doente percebem e lidam com o adoecimento e o seu tratamento, assumindo posturas que contribuem para alicerçar ou não a adesão. Pensar ações que visem ampliar a adesão, implica em incorporar tais atores ao processo, na medida em que integram o universo da pessoa doente.

É verdade também que a doença "provoca perda/afastamento de familiares (3.14, 6.13), das atividades sociais" (3.14) e "de amigos" (5.15), "leva ao isolamento fisico e de comunicação verbal com as pessoas" (3.15), além de que o fato de vivenciála pode suscitar sentimentos que causam o distanciamento do sujeito doente em relação aos outros: "o 'recuo'/retração em relação às pessoas é uma atitude que causa 'mal estar' ao doente" (2.32). Digno de nota também é o conteúdo da frase temática seguinte que põe em relevo a questão de que a doença acarretou modificações no território familiar devido ao processo de discriminação: "a doença/tb provoca mudança na vida, baseada no desprezo/ distanciamento/ discriminação, também vividos por aqueles que convivem com a doente" (16.8) e: "a doença/tb provoca discriminação, afastamento das pessoas e a separação de objetos" (17.16). BERTOLOZZI (1991) obteve o mesmo achado ao proceder a estudo no Município de Taboão da Serra, em São Paulo, observando a ocorrência simultânea tanto partindo do doente, como partindo daqueles 
integrantes de seu grupo social. De modo geral, o doente revela-se como um incômodo, um embaraço, a ponto da familia remeter o problema à outra instância que diz respeito à internação hospitalar.

É importante verificar que existe um duplo caminho em termos de atitudes das pessoas em relação àqueles acometidos pela doença que vai desde o acolhimento até o repúdio. Por parte do doente, os "excessos" em termos de cuidados ou de afastamento, podem resultar também em atitudes que levam ao distanciamento, na tentativa de resguardar a própria identidade: "o cuidado excessivo por parte de alguns é tido como 'bajulação' e determina o recuar/retrair no relacionamento com as pessoas" (2.30).

Por outro lado, pode-se verificar também que: "a doença/tb determina um comportamento "diferente" dos outros em relação ao doente ('mais afeto') (11.17). A respeito desse último aspecto, GOFFMAM (1982) menciona que a familia, ou a vizinhança local, muitas vezes constróem "cápsulas protetoras" protegendo o doente através de uma série de artificios, dentre os quais, a não divulgação da doença para outros. Nesse "círculo encantado", nas palavras do autor, impede-se que penetrem informações que repercutam negativamente sobre o doente.

Segundo revelam alguns depoimentos, o preconceito se materializa, sob distintas formas, desde a representação sobre a contaminação "o preconceito da doença/tb é decorrência da sua transmissão por via respiratória, uma vez que propicia maior disseminação" (5.41), até a sua corporificação enquanto doença e, nesse caso, ganha maior expressão a AIDS: "a discriminação ocorre pois as pessoas pensam tratar-se de AIDS e não de tuberculose" (17.20) e "as medidas de isolamento executadas pela equipe de saúde provocam "ambigüidade" no doente sobre a verdadeira doença que o acomete (suspeita de AIDS)" (14.27).

A concretização do preconceito também se revela através do 'descaso' com o doente (10.16). Assim, as representações da coletividade sobre a doença mostram que "a doença/tb é tida como fato 'anormal' e gera preconceito (12.18), ao passo que "a apreensão da doença/tb como um processo 'normal' determina o sentimento de não discriminação" (14.45). Ou seja, da mesma forma que para o doente existe um padrão 
de saúde que é considerado como "normal", tudo o que foge a esse padrão de regularidade seria considerado como enfermidade. $\mathrm{Na}$ aparência, isso quer dizer que a representação do doente reflete a forma pela qual a coletividade imagina a doença. De qualquer forma, vale resgatar o conteúdo da última frase apresentada, uma vez que deixa transparecer a idéia de que o sujeito é o responsável por suscitar a discriminação, uma vez que tomando a doença como um fato de rotina, regular ou normal, a própria sociedade reproduziria o mesmo comportamento em relação a ele. Em parte essa representação parece guardar um conteúdo verdadeiro, na medida em que o ideário sobre o significado da doença vai determinar o agir em relação a ela. Por outro lado, mais uma vez imputa ao próprio doente a responsabilidade por gerar ou não o preconceito em relação à doença, o que facilita a explicitação e a legitimação dos comportamentos discriminativos genéricos da sociedade em relação ao doente. Isso fica bastante claro quando se verifica que a forma do doente lidar com o preconceito se dá através do seu sentimento conformista "o que eu fiz foi entregar a Deus" (10.17). NETTO e CARVALHO (1996) ao interpretarem o sagrado e o espiritual no cotidiano, à luz da teoria de Heller, colocam que os gestos de pedido de ajuda, de benção ao divino, presentes nos momentos marcantes ou rotineiros da vida cotidiana, não são apenas manifestações de uma religiosidade aparente, cultural ou mágica, mas há realmente uma espiritualidade acorrentada a um deus que pode levar ao "progresso, ao conforto ou aprofundar a alienação". O espiritual pode dessa forma, reforçar um processo de fuga alienante, conforme pode ser verificado através da frase temática anteriormente apresentada.

Por outro lado, a questão da discriminação como representação particular ou individual da doença embasa-se historicamente na sua origem eminentemente social, como também no risco biológico. Em relação a este último, vale fazer referência a estudo desenvolvido no Reino Unido, que ainda que apresente características sociais muito diversas do Brasil, revela, a título de exemplo, uma realidade que se deve ter em conta no processamento dos programas de controle da tuberculose. $\mathrm{Na}$ investigação, que foi conduzida em 1978, o risco dos contatos íntimos de pacientes com baciloscopia positiva 
desenvolverem tuberculose ativa era de $0,3 \%{ }^{2}$. Os contatos foram definidos como os membros da familia do caso notificado, com quem eram compartilhados alguns cômodos do domicílio, dentre os quais, a cozinha e/ou o banheiro, ou ainda parentes que visitavam freqüentemente o doente (HUSSAIN et al., 1992). Um outro aspecto refere-se ao fato de que aproximadamente 5 a $10 \%$ das pessoas infectadas com o bacilo da tuberculose podem desenvolver a doença clínica em até dois anos após a infecção, sendo que outros $5 \%$ poderão ser acometidos pela enfermidade em algum período do futuro (JOHNSTON e WILDRICK, 1974; MILLER, 1993). A British Thoracic Society recomenda, nesse sentido, que o seguimento dos contatos seja realizado por dois anos após o tratamento do caso (HUSSAIN et al., 1992).

Dando continuidade à interpretação das representações dos doentes em relação à tuberculose, verificou-se que estas estão permeadas também pela associação a outros conceitos. Dentro desse universo, a noção de temperatura/ventilação é a que mais parece impregnar a origem da doença. Assim, é evidente a sua analogia ao "frio/gelado" (1.21, $2.38,9.4,13.11$ ), com a exposição à chuva ou consumo de substâncias com baixa temperatura. Subjaz à causação da tuberculose a idéia do choque térmico ("do corpo quente que se expõe à temperatura mais baixa": 9.4, 15.17, 17.2), associado ao “debilitamento do organismo" (17.2), concepções essas tão carregadas de sentido para os doentes que, após o curso da doença os direcionam para atitudes de controle, "de não exposição a esses falores" (2.39).

\footnotetext{
: No que se refere a dados sobre número de infectados em relação a um caso indice, segundo JOHNSTON e WILDRICK (1974) nos Estados Unidos da América, na década de 70, estimava-se uma taxa anual de infecção de aproximadamente 1 a $2 \%$ por ano, o que indicava um novo infectado para cada 5.000 a 10.000 pessoas por ano. Ainda segundo esses autores, a probabilidade de aquisição da tuberculose-infecção está relacionada à densidade dos organismos no meio ambiente em um determinado momento. que pode estar relacionada ao doente, ao uso de drogas e à própria natureza do meio ambiente. Em relação à pessoa, a infectividade depende de uma série de fatores, dentre os quais a natureza do esforço expulsivo por ocasião do ato de tossir, do estado bacteriológico da secreção brônquica, da extensão da doença e da presença de cavidade. Antes de dar início à quimioterapia, há clara relação entre a presença de bacilos no escarro e a infectividade. Os autores esclarecem que em um estudo desenvolvido nos EUA na década de 70 , verificou-se que na presença de baciloscopia positiva, $12 \%$ dos contatos desenvolveram a doença, enquanto que quando a baciloscopia era negativa, somente $1,4 \%$ desenvolveram a doença. Em relação ao uso das drogas, verificaram ausência de risco para os contatos quando o caso-indice havia dado inicio ao uso de quimioterapia e tomado a medicação por pelo menos duas semanas.
} 
Além disso, interpreta-se a doença como associada ora "à umidade, ora $\grave{a}$ ventilação inadequada, tanto do ambiente de trabalho, como da moradia" (11.13), fato que está respaldado cientificamente, uma vez que, segundo JOHNSTON e WILDRICK (1974), Wells já havia introduzido a noção dos núcleos de gotículas, os quais seriam a menor porção das gotículas, expelidas por ocasião da tosse, fala ou espirro, que continuariam no meio ambiente suspensas por longos períodos de tempo e que poderiam ser inaladas, carreando os bacilos para os alvéolos, sendo responsáveis por infectar as pessoas.

Vale dizer ainda que a representação da doença está correlacionada "à presença de odor fétido" (11.13), resgatando antigas concepções sobre a causa da doença, como a que está embutida na Teoria Miasmática, largamente empregada como explicativa da doença no decurso da Idade Média. Ainda segundo as representações encontradas no presente estudo, a doença parece estar associada à "aglomeração de pessoas em ambientes fechados" (12.16).

Cabe ainda destacar que existem metáforas que representam o processo mórbido para o paciente, como pode se depreender através das frases temáticas a seguir:

- "A apreensão do doente em relação à orientação médica está centrada num 'tuberculoso embutido dentro de mim', (8.6);

- "O inicio da doença/th é associado a 'coisa que tava me furando' ('lesão nas nádegas')" (18.1);

- "A doença/tb progride no interior do organismo (... desceu em vez de ficar no pulmão ) " (18.5)

Tais frases revelam que a tuberculose manifesta-se para o doente como algo ("tuberculoso") que evolui, que não permanece circunscrita a determinados órgãos, mas que provoca um processo de agressão ao organismo. Assim, ela é tanto representada como um estado (4.1), pontual, como configurando-se num processo de degeneração, de “debilitamento fisico progressivo (emagrecimento, 'desânimo', fraqueza) (11.4, 13.3). 
A primeira concepção está permeada por uma noção estática da doença e não como um momento dinâmico, enquanto que a última concepção evidencia um cunho dinâmico. ainda que de evolução degenerativa, ao mesmo tempo que remete à idéia de fatalidade, de não superação da enfermidade.

No que se refere às representações em relação à causa da tuberculose, verificouse que alguns tomam para si próprios a responsabilidade pelo aparecimento da doença, julgando-a conseqüente a certos fatores, enquanto que, para outros, a causa da moléstia não é localizada, podendo seu acometimento ocorrer de forma aleatória. Quando imputada ao plano pessoal, verifica-se que a tuberculose é considerada como conseqüência de um fato que gerou uma situação emocional conflitiva, como: “"depressão', secundária ḋ ruptura no relacionamento amoroso, não dormir e não comer bem, viagens rápidas e freqüentes" (2.31). Ou, "A doençallb inicia sua manifestação (fehre) após situação 'emocional', conseqüente ao contato com familiar internado por luberculose" (13.1). Como pode ser visto, mesmo que a raiz das questões acima levantadas pudesse ser localizada na forma de vida, os sujeitos parecem remeter a causa da doença ao âmbito estritamente emocional que a desencadearia.

Existe menção ao fato de que a doença seria secundária a um tipo de comportamento relacionado ao trabalho. resultado de um processo de "imposição própria para o bom desempenho, por ocasião de um dever a cumprir" (7.3). Ou seja, a exigência para o cumprimento do dever é imputada ao próprio individuo, que não percebe, em última instância, que essa obrigação converte-se em necessidade derivada de sua inserção social.

Da série de fatores externos identificados como causadores da tuberculose verificou-se a alimentação inadequada $(4.8,7.3,17.28)$, ou a falta de alimentação (6.5), o excesso de trabalho (4.8. 7.3), o fumo, o álcool $(5.13,18.6)$, o café, o contato íntimo direto com tuberculosos. a exposição à chuva (4.8), ao ambiente frio e o desgaste físico (18.6).

Por outro lado, alguns doentes referiram desconhecer a fonte de infecção (1.14, 10.18. 15.3), embora afirmando corretamente que a doença pode ser adquirida através 
do "ar" $(13.6,15.3)$ ou em locais onde transitam muitas pessoas, como por exemplo nos meios de transporte coletivo, como ônibus (15.3). Ao apontarem o desconhecimento sobre a fonte de transmissão, algumas pessoas apresentaram "sentimento de culpa" $(10.18,12.15)$ por esse fato, uma vez que se viram acometidos pela doença sem localizar a sua procedência $(10.18)$.

Coexistem também representações da doença a partir de entidades externas ao indivíduo, dotando à causação da doença, um caráter mágico/místico: "a doença é provocada por 'vingança' por 'entidade que causa o mal'” (14.50).

LOYOLA (1984) descreve um estudo realizado na década de 80 com uma coorte de favelados do Rio de Janeiro, que revelou que as pessoas consideravam a saúde e a doença como fenômenos que, em última instância, escapam ao controle do homem, como algo que, no limite, é produto de forças sobrenaturais ou, mais comumente, de Deus. Essa concepção mágica, além de determinar formas de convivência com a doença, ocasiona importantes repercussões na procura da assistência à saúde, aí podendo residir a explicação para o longo tempo decorrido entre o aparecimento dos primeiros sintomas e a efetivação da busca da assistência, na medida em que o doente vê como possibilidade de solução para o seu agravo à saúde, a sua sujeição a regimes terapêuticos condizentes com essa forma mágica de representação da realidade.

Por outro lado, evidenciaram-se também concepções que retomam o papel do homem desde uma perspectiva conformista e universalista, na medida em que " $a$ doença/tb é 'algo predestinado"” (12.28), que "ter tuberculose independe da pessoa ('quando tem que vir não escolhe', 'não escolhe nem pobre, nem rico')' (10.21), sendo que "a doença e os problemas econômicos não provém do acaso, mas eles ocorrem para valorizar a vida" (14.54).

Saindo desse plano, que parece estar respaldado por uma concepção metafísica do mundo e tentando buscar algumas âncoras no plano biológico, sabe-se que a chance de um indivíduo não infectado com o bacilo da tuberculose tornar-se infectado depende de alguns fatores, como a extensão, intensidade e freqüência da exposição ao bacilo. Além disso, há atributos que dependem do bacilo, pois diferentes cepas podem variar na 
sua capacidade de infectar os humanos. No que se refere às questões de ordem pessoal, a literatura indica a idade, o estado nutricional, a condição física, o estado imunológico e a existência de outras doenças intercorrentes que podem contribuir para o desencadeamento da doença (SUTHERLAND, 1976). É fato que essas características não podem ser analisadas de forma isolada, mas têm a ver com a forma como o indivíduo está alocado socialmente, ou seja, a exposição e a probabilidade de adoecimento dependem da sua inserção no processo de produção social, com tudo que pode disto advir. Entretanto, é evidente que as concepções acima referidas devem ser levadas em conta na produção dos serviços de saúde, pois podem demandar atitudes de complacência ou de conformismo frente ao acometimento pela doença, que podem repercutir no processo de adesão, na medida em que outorgariam a um plano supostamente desvinculado da intervenção humana, tanto a causação das doenças como o seu próprio desenvolvimento no sujeito.

Um outro conceito que se revelou nos depoimentos refere-se à resistência/suscetibilidade, sob a forma de negação da doença, acreditando a pessoa, que nunca será seu alvo, conforme pode ser verificado: "mesmo que a doença/tb esteja presente na familia, existe a idéia de que a pessoa não será alvo da mesma" (9.20). Mas, esse tipo de atitude não se limita ao doente, como pode ser visto a seguir: "há descrédito materno quanto à manifestação da doença/tb” (3.7), ou seja, a mãe não admite que o filho possa estar desenvolvendo a enfermidade. Interessante verificar ainda o fato de que o doente assume realmente a doença como um processo individual e isso é corroborado pelo depoimento de que o diagnóstico provocou "surpresa", apesar da existência de familiar doente, também com tuberculose (4.14). Ou seja, parece haver uma certa desvinculação do fato de que a doença pode acercar-se do próprio corpo.

A questão da internação também se fez presente nas representações revelando um certo tipo de comportamento da sociedade em relação à enfermidade, pois: "para $a$ doente, a concepção comum de tuberculose é a de que a doença leva, necessariamente, à internação em hospitais de isolamento" (17.14). Na época em que era uma das únicas alternativas para o controle da doença, a necessidade de internação em virtude da tuberculose, determinava à coletividade, sentimentos de medo, revolta, isolamento, marginalização, além de aprofundar o preconceito, na medida em que se retirava o 
doente do convívio social para impedir a progressão do processo contagioso. Essa conduta, largamente utilizada no final do século até meados dos anos 70 , entretanto, foi sendo finalmente substituída pelo tratamento ambulatorial que, segundo FOX e MITCHISON (1975), se constituiu num marco na história da tuberculose que, diferentemente do que antes se imaginava, não expunha os contatos íntimos familiares a um risco importante de infecção, após o início da terapêutica medicamentosa.

A internação apresenta uma tradução diferente daquela que parece conduzir o raciocínio médico já que "o significado da internação para o doente se baseia na ruptura do seu cotidiano e para o médico no signo patológico" (5.11), assim como: "a internação de urgência, para o profissional médico, pauta-se na manifestação grave da doença e, para o doente, pauta-se na interrupção de suas atividades do cotidiano" (14.8). Assim, evidencia-se nas duas frases anteriormente mencionadas, que a internação não é incorporada como um fato usual, de rotina, mas que rompe com o cotidiano já modificado em decorrência da própria doença. E isso pode ser corroborado pela própria atitude da pessoa frente à internação, pois explicita-se para o doente a necessidade de “' 'preparo' prévio para a internação hospitalar materializado sob a forma de 'tomar banho', 'me trocar'” (14.13), como que cumprindo um ritual para o início de uma nova etapa de demandas.

O redirecionamento das práticas de assistência que eram anteriormente desenvolvidas nos hospitais, para o tratamento no âmbito domiciliar proporcionou, sem dúvida, ganhos em vários aspectos: tanto no que se refere à reintegração do doente à sociedade, como à diminuição dos custos ${ }^{3}$ (FOX, 1972), como na possibilidade de que os familiares/amigos proporcionem um alicerçamento maior no processo de tratamento, ao mesmo tempo que possibilita a diminuição do estigma em relação à doença, uma vez que o doente que compartilha do cotidiano $\mathrm{cm}$ socicdade percebe muito mais

\footnotetext{
${ }^{3}$ JOHNSTON e WILDRICK (1974) mostram que, nos EUA, a diminuição da permanência nos hospitais teve início com a institucionalização dos regimes terapêuticos no nivel ambulatorial. Assim. de um período de 299 dias em 1952, houve um decréscimo para 87 dias em 1972. O custo do tratamento no nível ambulatorial na década de 70, naquele pais, era de $\$ 11,55 /$ dia, enquanto que no âmbito hospitalar era de $\$ 35$ a $\$ 40 /$ dia. Este valor não é muito diferente daquele encontrado na Tanzânia, o qual, segundo a Organização Mundial da Saúde em 1993, era de US\$30 (WORLD HEALTH ORGANIZATION, 1993). No Brasil, o custo do tratamento ambulatorial está avaliado em aproximadamente U\$70,00 (MELO et al., 1997).
} 
construtivamente o seu papel social (JOHNSTON e WILDRICK, 1974). Isso parece estar evidenciado no conteúdo das seguintes frases temáticas: "para o doente, o ambiente hospitalar piora a evolução da doença" (15.20), "a rotina hospitalar impede a conciliação do sono" (14.32) e, "a possibilidade de se realizar o tratamento no âmbito domiciliar é qualificada como 'ótima'," (17.15).

Por outro lado, a internação, ainda que identificada como negativa pelo doente “determina um relacionamento de "amizade" entre o médico e o doente" (14.14), o que possivelmente se evidencia pelo contato mais íntimo na relação que se estabelece nesse ambiente, fazendo com que o doente se sinta mais próximo do trabalhador de saúde.

É interessante verificar que a internação também pode ser apreendida como uma situação "conveniente", na medida em que ela: “... $\dot{e}$ valorizada positivamente, por permitir compartir a situação de doença com outros que vivenciam o mesmo processo" (12.7), ou seja, a possibilidade de encontrar identidade no que se refere à evolução da doença e mesmo em relação aos sentimentos que emergem por ocasião do desenvolvimento da enfermidade com outros que vivenciam o mesmo processo, faz com que o doente assuma a internação a partir de uma outra perspectiva.

Uma outra noção é de que: "o conceito de saúde-doença é um processo individual, que não pode ser transmitido ao outro" (4.39). A doença, dessa forma, é tida como algo que se refere à dimensão singular e inerente ao próprio doente. Em outro depoimento verifica-se que o agravamento da enfermidade, ainda que imputado num primeiro momento aos médicos, " 'é desculpada' pelo doente, na medida em que os fatos/doença, ocorrem por responsabilidade das próprias pessoas" (14.60). Ou seja, existe um movimento que parte do próprio indivíduo, em reconhecer o processo como único, de geração intransferivel de sentimentos e que se remete ao âmbito pessoal. $O$ próprio doente sente-se culpado pelo desenvolvimento da doença, trazendo para si a responsabilidade pelo processo de adoecimento e essa última representação parece ser o resultado da forma como a própria sociedade ao longo dos tempos lida com a questão da enfermidade. NETTO e CARVALHO (1996), ao decodificarem a Teoria das Necessidades de Agnes Heller para as práticas do serviço social, afirmam que as 
determinações da cotidianidade impelem a que cada indivíduo se perceba somente como singular. Dessa forma, a dimensão relativa ao ser humano na coletividade se revela na aparência, subsumida à dimensão da singularidade.

CRAWFORD (1980) ressalta que principalmente nas culturas contemporâneas ocidentais, as noções sobre saúde-doença, apresentam esse caráter, que em larga medida conservam o significado da medicalização, que imprimiria a força do poder da medicina sobre o cotidiano, conformando uma ideologia sobre saúde, na qual a responsabilidade sobre a saúde seria remetida linearmente ao plano do indivíduo. Nessa perspectiva, conforme aponta FOUCAULT (1977), a medicina tem se tornado a ciência do individual, reforçando tanto a culpa que o indivíduo apreende para si mesmo, como ampliando o fôsso existente entre as ações de caráter individual e coletivo, já que para estas últimas, a medicina da forma como está constituída, não daria conta de responder. Mas o próprio Estado culpabiliza os indivíduos pela doença, para ocultar a evidenciação de seu papel (do Estado) no que toca ao estabelecimento de políticas de saúde e sociais, de maneira geral, que teriam o objetivo de melhorar a qualidade de vida dos cidadãos.

Da mesma forma, no âmbito dos serviços de saúde, os profissionais também remetem a causa das doenças ao plano dos indivíduos, pois a lógica do raciocínio em saúde é funcionalizada por um padrão de assistência conformado pela detecção de sinais e sintomas, sua codificação em um diagnóstico e a aplicação da terapêutica que leva em conta, de forma geral, a concepção eminentemente biológica do ser humano, localizando em fatores ou em atributos "não controláveis" ou "não passíveis de intervenção", as questões que decorrem de sua inserção social. Dessa forma, resta ao indivíduo reproduzir essas concepções e incorporar a enfermidade como algo por ele produzido e que deve ser contido no seu espaço.

De acordo com LEOPARDI (1992), o processo ser saudável/adoecer/curar transita entre as esferas do individual e do coletivo, o que exige um olhar voltado simultaneamente para esses dois elementos que, na sua aparência, podem parecer antagônicos. Não há como apreender a doença somente sob a perspectiva individual, uma vez que na perspectiva da unidade dialética indivíduo-coletivo. o entendimento da forma como se concebe a doença a partir da cunha individual se constitui em uma 
reprodução da forma como o seu grupo social apreende o processo saúde-doença. Assim. imputar unicamente ao indivíduo a causação da doença significa um viés de percepção da realidade, com a negação da visualização da forma como se produz a doença na sociedade, operando-se então uma redução da sua determinação orientada ao polo individual.

Como foi visto, o significado da doença assume diferentes representações para os doentes, os quais colocam em pauta as diferentes condições a que estão expostos em termos de vida e de inserção social, além da forma como o corpo tem sido historicamente interpretado e utilizado como força de trabalho pelas sociedades. De igual modo, também há diferentes representações da doença quando entram em cena outros protagonistas que integram o processo de produção da saúde. Se para o doente a interpretação da tuberculose está alicerçada no seu cotidiano e na sua possibilidade de viver, de desenvolver as suas atividades de reprodução social (5.10), para o médico tal interpretação está conformada em geral pela codificação dos sinais e sintomas sob a forma de um diagnóstico. Ou, conforme afirma HARDY (1994), o profissional de saúde define a importância da queixa em função do risco de vida, enquanto que para o doente a repercussão da enfermidade sobre o desenvolvimento das atividades diárias é o pontolimite para a valorização dos sinais e sintomas. Mas, evidentemente, isso não quer dizer que não possa haver concordância entre as concepções dos trabalhadores de saúde e dos doentes.

Uma outra perspectiva representacional que emergiu dos depoimentos analisados refere-se à questão da concepção da doença pelo doente, não somente a partir da esfera que o setor saúde tenta imprimir à sociedade, seja pela influência dos profissionais de saúde, mas fundamentalmente pela forma como a sociedade tem essa noção representada. Aqui fala-se especificamente do fato de que "as informações gerais sobre a doença'lb. divulgadas pela escola, exacerbam o 'medo' em relação à doença, na medida em que ela pode causar a morte" (13.22). O que se verifica é que o local que poderia ser um espaço privilegiado para contribuir para a disseminação de um conhecimento com potencial transformador e desmistificador em relação à doença, ou seja, o âmbito educacional. ao contrário, põe em evidência a complexidade da doença em função da situação-limite a que pode levar. isto é. a morte. Essa postura não só 
aprofunda o preconceito em relação a ela, como também ajuda à negação da presença da doença no tecido social, mantendo-a intocada.

Provavelmente como reflexo dessa atitude, a tuberculose permanece para muitos como uma doença desconhecida $(5.5,17.6,18.7)$, tanto no que se refere ao seu "modo de transmissão" (3.8), como quanto à sua evolução. Ainda reforçando as reflexões anteriores, vale destacar que apesar de terem decorridos quase cinco décadas do advento da terapêutica para o tratamento da doença, ainda ocorre "o desconhecimento da sua possibilidade de cura" $(1.9,10.5)$.

Cumpre destacar ainda que a prontidão para a recepção de informações sobre a doença não é algo que se expressa de forma homogênea para todas as pessoas. Há alguns que não desejam obter informações a respeito da doença: "o doente manifesta ambigüidade quanto à recepção de informações sobre a doença/tb” (3.6). A não detecção desse tipo de comportamento nos serviços de saúde pode levar a determinações, por parte da equipe de saúde, que traduzem esse comportamento apenas como uma falha, ou como uma não necessidade, que é deixada de lado, ao invés de aproveitada para a introdução de novos elementos/conceitos que ajudem a vivenciar o processo saúde-doença e que podem determinar muitas vezes, a "prontidão", a eficiência na busca precoce da assistência. Trata-se de proceder a um trabalho de cunho eminentemente educativo que, ainda que não produza um sentido evidente num primeiro momento, possa articular-se ao modo de vida dos sujeitos e que, por conta dessa rede, resultem na produção de significados sobre a saúde e a doença, no entendimento sobre o próprio organismo, constituindo-se em elemento capaz de definir a necessidade da busca de assistência.

A ambigüidade também poderia ser explicada pelo fato de que o conhecimento sobre a doença pode produzir um sentimento de medo, por saber-se portador de um processo degenerativo. Por outro lado, a falta de informação também traz à tona outro tipo de sentimento: "A desinformação provoca dúvidas e a imaginação de estar acometido por doença grave (AIDS)" (14.25). Essa questão via de regra não é trabalhada pelas equipes dos serviços de saúde. A tuberculose, que durante muito tempo manteve-se como uma das principais doenças capazes de causar medo, hoje foi 
deslocada dessa posição pelo aparecimento da AIDS. Grave deixa de ser a tuberculose para ganhar um estatuto de pouco relevante, uma vez que, na escala de valores de saúdedoença, a iminência da morte, ou seja, a inevitável fatalidade, outorga o estatuto de doença que mais amedronta à AIDS.

Ora, a pluralidade de concepções sobre a tuberculose e a riqueza de conceitos extraídos dos depoimentos remete à necessidade de verificar, conforme aponta HERZLICH (1991) que a dupla oposição entre saúde-doença e indivíduo-sociedade é que dá sentido ao fenômeno doença. "Por meio da saúde e da doença temos acesso à imagem da sociedade, de suas imposições".

Daí que o fenômeno doença deve ser analisado de forma a abranger o entendimento da estrutura social. Ou seja, a doença apresenta-se através de manifestações de cunho individual, mas reflete o estar no mundo social, ou seja a conseqüência do estar no mundo sob determinadas condições. Também a tuberculose necessita ser visualizada a partir dessa perspectiva, que transcende às manifestações de cunho clínico-biológico inerentes às ações de um determinado agente etiológico, mas que remete à sua interpretação à partir da ótica da determinação social e que como tal deveria ser entendida no âmbito dos serviços de saúde. Essa interpretação da doença pelos trabalhadores de saúde possivelmente resultaria em uma outra forma de prestação de serviços, baseada nas necessidades que emanam do cotidiano das pessoas em correlação à sua posição na sociedade.

No que se refere à forma como repercute sobre a vida das pessoas, algumas frases temáticas revelam que a tuberculose "não modifica a vida" (14.46), possibilitando "a continuidade da rotina de vida (passear, praticar esporte)" (13.12); e o "não afastamento de amigos" (4.19). Entretanto, para outros, a tuberculose causou mudanças tanto na forma de pensar ou posicionar-se diante da vida e do processo saúdedoença, como aquelas relacionadas às transformações ocorridas no relacionamento com outros e com o próprio cotidiano.

No que diz respeito à forma de pensar ou posicionar-se diante da vida e da doença, verificou-se que a tuberculose fez com que ocorresse "mudança na vida do 
doente, em termos de conscientizá-lo sobre a sua fragilidade, possibilidade de morrer" (2.25) e "se constitui em uma 'experiência' válida, pois desperta para a necessidade de precaução com relação a outras doenças" (11.10). Ao mesmo tempo, observou-se que "a doença/tb leva ao fortalecimento pessoal, a 'encarar mais as coisas', a acreditar mais em si mesmo, enquanto potencialidade e capacidade" (2.33). Ou, ainda "a doença determina 'medo' subsequente de adoecer" (2.40) e "a interrupção de regime (dieta) alimentar" (7.17). Ou seja, o acometimento pela doença repercute internamente no individuo, levando-o a compreender o seu corpo como passível de alterações e a constatar a sua enfermidade. Ao mesmo tempo, a superação da doença concretiza a capacidade do corpo em dominar alguns tipos de processos, possibilitando uma nova forma de olhá-lo, pois que este revela a sua suscetibilidade.

É importante verificar que o fato de ser acometido pela doença leva a um movimento posterior de "valorizar a vida" $(2.44 ; 17.26)$, bem como "o corpo e a saúde" (12.26, 15.15, 17.26) e essa valorização é concretizada em ações como "parar de fumar, boa alimentação, deixar de ser hipocondríaca" (17.26), as quais traduziriam modificações de comportamento na busca da regularização da vida.

As representações acima mencionadas indicam que o adoecimento consubstancia um momento de um processo maior que é a própria vida, leitura mais totalizante do que a de HERZLICH (1991), que qualifica a enfermidade como um evento que ameaça ou que modifica, "(...) às vezes irremediavelmente, nossa vida individual, nossa inserção social (...)". Ora. na medida em que a doença pode repercutir profundamente no desenvolvimento da vida, não pode ser considerada apenas como um evento, mas como um subprocesso que dinamicamente integra toda uma trajetória da vida.

Articuladas às concepções sobre a doença, foram mencionadas ainda representações que se referem às mudanças no cotidiano do doente e das pessoas que com ele convivem: "A doença/tb provoca mudanças na vida do doente e da família (filho) ("deixar de sair (1.20) à noite (2.42, 9.12)", " para não tomar friagem" (1.20, 15.15), "não tomar chuva" (9.12), "não tomar refrigerante, tomar sucos")" (1.20), "parar de fumar" $(6.1,9.12,15.15,17.26)$, "interrupção da ingestão de álcool" (6.1, 12.26). Revelam que o fato de vivenciar a doença leva a uma sujeição do indivíduo a 
assumir comportamentos que evidenciam uma dinâmica de regularização da vida: "não zoar" (9.12), e que pode provocar mudanças como a "alteração das atividades escolares" (2.15), "interrupção da educação formal" (3.15), além de "reduzir/interromper a prática de esportes" $(2.42,3.15)$.

Nem sempre essas mudanças são assumidas diretamente pelo doente, mas determinadas ou assumidas por aqueles que com ele de certa forma convivem, conforme explicita a frase temática a seguir: "a limitação às atividades esportivas que a doença/th causa somente é evidenciada a partir das orientações de amigos" (2.36). Além disso, observa-se que a doença modifica o comportamento em relação a hábitos de vida: " $a$ vivência da doença influencia o comportamento dos familiares (no que se refere à necessidade de alimentação adequada)" (7.16). Destaca-se também o fato que "a doença/tb determina o afastamento do uso de objetos comuns no ambiente familiar" (11.20), o que mais uma vez evidencia o preconceito em relação ao doente enfermo.

Destacam-se as repercussões sobre o trabalho, na medida em que a doença "determina o afastamento/interrupção das atividades de trabalho $(5.45,11.18,14.3$, 15.15, 17.35), bem como "impede/diminui a capacidade para o desenvolvimento normal de atividades do cotidiano" $(2.42,4.2,14.23,15.27,16.2)$ "e dos movimentos do corpo (devido à dor)" $(3.15,15.27,17.35)$, "determina mudança de disposição" (4.2), no "ritmo de vida" (5.45), além da "diminuição de 'resistência física' (4.2), sendo que a interrupção das atividades relacionadas ao trabalho variou de três (6.1) a seis meses (15.9). O exposto acima evidencia a ruptura que traz a doença sobre a vida do doente, particularmente sobre o processo de produção social, tendo como conseqüências: "o ingresso no INSS, a mudança no nivel econômico" (5.45, 11.18), enfim: "a ruptura na vida: antes/após a doença (10.20).

As frases temáticas relacionadas anteriormente revelam, na aparência, facetas que se referem ao âmbito restrito do indivíduo doente. Mas, ao tomar a tuberculose como enfermidade cuja determinação é marcadamente social, não se pode desvincular a análise da sua causação dos efeitos que pode produzir junto ao coletivo. Tal análise deve estar orientada para a relação indivíduo-coletivo uma vez que todos os fenômenos que incidem sobre os sujeitos particulares estão diretamente articulados à coletividade, com 
implicações nas esferas da produção e da reprodução social. Investigações deveriam ser realizadas, para buscar evidenciar o impacto da tuberculose nas dimensões da produção social, bem como suas repercussões na vida particular dos indivíduos, as quais possivelmente iluminariam as intervenções em saúde a partir de uma perspectiva centrada nas necessidades dos sujeitos acometidos pela doença.

Além disso, outras transformações foram identificadas, como: "mudar momentaneamente de moradia, na tentativa do doente ficar mais próximo à UBS" (3.25), o que se refere à questão do acesso do doente à assistência à saúde. Pergunta-se nesse sentido, até que ponto a regionalização dos serviços de saúde, conforme sustentada como um princípio do Sistema Único de Saúde (SUS), tem sido implementada, para minimizar o deslocamento e a peregrinação dos doentes às unidades de saúde? Através da análise da trajetória percorrida pelos doentes até a evidenciação do diagnóstico definitivo, infelizmente se depara com a ineficiência do setor saúde em responder às demandas dos doentes. Verificou-se que grande parte deles tiveram seu diagnóstico efetivado pelo nível hospitalar, para depois serem encaminhados às unidades básicas de saúde. Assim, indaga-se também, até que ponto as dificuldades na implementação dos princípios que regem o SUS interferem na progressão das taxas de abandono ao tratamento contra a tuberculose? A hierarquização das ações de saúde, se realmente operacionalizada. ao lado do trabalho educativo, da disponibilidade de equipamentos de saúde, facilitaria o estabelecimento mais precoce do diagnóstico e tratamento. Essas questões permanecem por ser respondidas, apesar de que a prática profissional, bem como a evidenciação da realidade que se foi revelando na medida em que o presente estudo era conduzido, mostram que se está diante de um processo de desmantelamento do sistema público de saúde, que se objetiva no cotidiano da assistência e que se traduz de fato pela desarticulação das ações nos serviços de saúde.

Sumarizando o que foi visto nesta primeira parte, verificou-se que a tuberculose ainda é uma doença impregnada pelo preconceito e pelo medo daqueles por ela acometidos e que há uma associação entre a sua presença e a irregularidade perante a vida, o que imprime à enfermidade um caráter de moralidade. Mas, coexistem situações em que a doença faz modificar o comportamento dos outros em relação ao doente, fazendo emergir atitudes de amparo em relação a eles, sendo que de modo geral, parece 
ainda haver um desconhecimento da coletividade perante a tuberculose. De modo geral, os sinais e sintomas que conformam a doença não são reconhecidos e a gravidade da enfermidade somente é observada a partir do momento em que aparecem determinados sinais, dentre eles o mais importante, é o escarro hemoptóico.

Há uma marcante relação entre a doença e a categoria trabalho, tanto no que se refere à perspectiva de causalidade, como do fato de que a enfermidade determina rupturas ou modificações importantes no cotidiano da produção e da reprodução social. A noção de causa da doença de modo geral está assentada no plano biológico, ora sob uma perspectiva ontológica, ou seja, do corpo como um receptáculo da doença, ora sob uma perspectiva dinâmica, ou seja, de um suposto equilibrio do organismo, que é modificado com a doença. Há ainda uma tendência à associação de um fator ou, quando muito, da sua somatória para a ocorrência da doença. Evidencia-se ainda a analogia entre a tuberculose e a consumpção, verificando-se que a forma como a enfermidade é vista pela sociedade impõe ao doente exclusividade na culpabilização pelo processo de adoecer.

Finalizando esta primeira parte, verifica-se que a forma de interpretar a tuberculose é peculiar ao indivíduo, mas está permeada pelo contexto social. A decomposição dos depoimentos em frases temáticas possibilitou o desvendamento da vida cotidiana e a compreensão da forma como os entrevistados entendem a enfermidade. Para HELLER (1991) não seria possível a apreensão dos processos reais se não se estudasse o significado das interrelações na vida cotidiana. $O$ seu conteúdo e a sua estrutura não são idênticos em todas as sociedades e para todas as pessoas e reflete a ocupação do ser humano num lugar determinado na divisão social do trabalho. A vida cotidiana, como o conjunto de atividades que caracterizam a reprodução dos homens, é a forma imediata de apresentação da genericidade do homem e aparece como a base de todas as reações dos homens a seu ambiente social. Para a mesma autora, há um constante transitar entre o singular e o genérico, ou seja, há uma relação dialética entre o modo como o indivíduo vive na sociedade, e o cotidiano é a objetivação dessa relação. $O$ homem particular, conceito por ela definido, refere-se ao momento em que o o ser humano se apropria da genericidade no seu ambiente social. E é importante observar que 
o momento a que aqui se refere integra a processualidade da constituição e do desenvolvimento do ser social.

As representações encontradas evidenciam modalidades do pensamento sobre a tuberculose, cujo entendimento é fundamental para que a assistência responda às necessidades nela reveladas. Conforme apontavam RUBEL e GARRO (1992), o conhecimento sobre a cultura em saúde tem se tornado uma ferramenta crítica para o controle da tuberculose. São informações, portanto, que devem orientar o planejamento das práticas em saúde. $E$ isso absolutamente não é um processo dificil, nem ao menos complexo, na medida em que há várias alternativas metodológicas que apoiariam o desenvolvimento de investigações rápidas sobre as representações de uma dada população local. Lidar com o conhecimento que têm os sujeitos sociais e compartilhar de informações acerca do corpo redundaria na compreensão mais ampliada do processo saúde-doença, busca mais precoce da assistência, no estabelecimento de um processo de credibilidade entre o profissional de saúde e o doente. bem como, conforme foi visto no presente estudo, facilitaria a compreensão dos processos que podem ou não levar à adesão ao tratamento, na medida em que estão intimamente relacionados à forma como o doente enfrenta a doença.

\subsubsection{Representações sobre a Assistência à Saúde}

As representações obtidas da análise dos depoimentos caracterizam, em primeiro lugar, a forma como ocorre a busca da assistência à saúde, ou seja, quais são os parâmetros que levam as pessoas a recorrerem ao serviço de saúde e, em segundo lugar, a forma como as pessoas a concebem.

Em geral, os depoimentos revelam que a busca da assistência é deflagrada por outra pessoa que não o doente, além de não ser imediata, quando do aparecimento dos primeiros sinais e sintomas. Assim, ora ela é "determinada pela figura materna" (7.1), ou "pelo empregador" (1.6, 10.3). 
Esses achados são corroborados por NOVOCHADLO (1984) que também verificou que as pessoas que têm algum vínculo com o doente são os primeiros a constatar a presença da doença, concebendo um certo "diagnóstico" da mesma. Explica que isso ocorre pois estes vivenciariam junto com o doente o processo saúde-doença no cotidiano, sendo detentores de outro tipo de olhar sobre o adoecer, que determinaria uma ação muito mais imediata para perceber as "anormalidades" do que o próprio doente. Para esses outros atores, a manifestação de sinais e sintomas configuraria noções de emergência e de necessidades, diferentes daquelas entendidas pelo doente. Conforme será verificado adiante, o doente percebe a necessidade da busca da assistência, mas por estar de certa forma preso a uma série de questões que dependem sobretudo da sua inserção no sistema de produção, e outras relacionadas ao seu cotidiano e que se referem especificamente às suas possibilidades de vida, faz uso de parâmetros bastante distintos daqueles utilizados pelos outros atores. Estes em geral, concebem a necessidade da busca da assistência como determinada pelo caráter estritamente biológico da doença e não através de sua mediação no cotidiano/inserção social.

É importante frisar que a busca precoce da assistência à saúde tem um papel fundamental na epidemiologia da tuberculose, uma vez que contribui para a menor disseminação da doença. Um outro dado de interesse é que parece existir uma diferença em termos de adesão ao tratamento, quando a busca da assistência é efetivada por iniciativa do próprio doente. segundo demonstram CASSELS et al. (1982). Os autores, ainda que referindo-se a uma realidade totalmente diferente da brasileira, ao descreverem estudo realizado no Nepal, afirmam que os doentes que procuram o serviço de saúde por sua própria conta, em geral apresentam maior grau de adesão ao tratamento do que aqueles que chegam ao serviço de saúde em decorrência da sua interferência.

Mas, JOHNSTON e WILDRICK (1974) advogam que o sucesso dos programas de controle da tuberculose reside principalmente na disponibilidade do serviço em se mostrar aberto ao que o doente expõe, indo ao encontro das pessoas, não se permitindo apenas aguardar passivamente a busca da assistência. Assim, vale resgatar que procedimentos que durante um tempo eram empregados sistematicamente no Estado de São Paulo, no interior do Programa de Controle da Tuberculose, como por exemplo, a convocação de faltosos, através de cartas ou de visitas domiciliárias, são preconizadas 
pelos autores anteriormente citados, como práticas que devem persistir na produção dos serviços de saúde, as quais impactariam positivamente sobre os indicadores de morbidade. Ocorre que, atualmente, o que se tem observado nas unidades de saúde do país e, mais especificamente, do Município e do Estado de São Paulo, é que, em função do processo de demolição do serviço público que fatalmente integra o ideário do modelo econômico que tem sido implantado, as práticas de saúde de primeiro nível têm sido relegadas a planos inferiores, com o desmantelamento gradual dos programas de saúde, incluindo o Programa de Controle da Tuberculose. Isso tem acarretado o não cumprimento de determinadas ações, que se antes não produziam um impacto significativo, pelo menos se constituíam como algum suporte do mesmo, conservando, ainda que precariamente e com uma série de falhas, uma dada qualidade na assistência prestada, que na atualidade tem deixado de existir. Ou seja, a quebra do sistema de saúde não tem sido acompanhada pela operacionalização de propostas que reorientem a assistência no sentido de mudanças no perfil de qualidade, que resultem no atendimento às demandas tanto dos indivíduos como da coletividade de maneira geral.

No presente estudo, o motivo da procura da assistência parece ser constituído distintamente entre os doentes: "a partir do surgimento de sinais e sintomas" (2.4, 17.3), "na fase aguda da sintomatologia" (8.3), ou ainda " a partir do agravamento da sintomatologia" (11.2). O que se verifica em muitos discursos é que existe uma situação-limite, definida pela capacidade do indivíduo de suportar a dor ("dor profunda nas costas": 17.7) ou os sintomas ("febre": 13.2, 17.7), a incapacidade para o desempenho das atividades do cotidiano, além das repercussões advindas da própria evolução da doença no âmbito familiar ("possibilidade de abandono dos familiares": 4.13). Essa situação-limite pode se materializar também quando configura-se como emergência, principalmente quando o que se apresenta é "a perda de sangue" $(5.6,9.9)$, código que define o momento quando a busca da assistência torna-se inevitável.

Entretanto, nem sempre os sinais e sintomas clássicos da tuberculose induzem à procura da ajuda institucional, nem mesmo a secreção pulmonar (14.2). Na realidade, parece estar longe da verdade que os sinais que consubstanciam a tuberculose sejam reconhecidos pela coletividade e determinem a procura da assistência médica num período de tempo mais curto. Em alguns depoimentos os sinais e sintomas da 
tuberculose acabaram por se tornar secundários, sendo que o verdadeiro motivo que promoveu a busca da assistência foi a manifestação de uma outra patologia, no caso a varicela (12.1). Esse achado coloca em pauta, por estranho que possa parecer, dado que a tuberculose é conhecida há tempos, a necessidade de maior informação à coletividade sobre seus sinais e sintomas. $\mathrm{Na}$ verdade, na medida em que o crédito quanto à eficiência dos medicamentos motivou uma esperança de controle da doença, a memória coletiva em relação à enfermidade passou a determinar com que os indivíduos deixassem de se ver como potenciais alvos da tuberculose.

Ainda que não evidenciado no presente estudo, vale resgatar os achados de BUCHILLET (1997) que procede a uma interessante abordagem ao analisar a forma como se processa a busca da assistência à tuberculose por indígenas brasileiros. Além de afirmar que a conceção sobre a doença repercute sobre a procura de atendimento, a autora indica que as concepções locais sobre os mecanismos de eficácia terapêutica são também determinantes na procura da assistência, ressaltando ainda que as noções de posologia, de duração do tratamento e da adequação do medicamento a um tipo específico de sintoma ou de doença assumem representações distintas nos grupos sociais, uma vez que estes partem das suas próprias vivências/processos culturais.

Necessário se faz enfatizar e, conforme anteriormente apontado, a busca da assistência parece estar correlacionada ao papel que a pessoa ocupa na sociedade. O que se quer dizer é que alguns depoimentos explicitam que a busca da assistência à saúde depende, em primeiro lugar, da possibilidade que o trabalho confere ao sujeito para dispor de tempo para a manutenção do seu corpo:

- "A busca da assistência à saúde não ocorre por ocasião do inicio da manifestação da sintomatologia, devido à impossibilidade de interrupção das atividades relativas ao trabalho" (15.2);

- “O 'medo' da possível demissão, em função da doença/th, determina a não busca de assistência à saúde" (4.11) 
Assim, a autonomia que tem o sujeito de controlar a sua própria saúde é relativa, na medida em que é outorgada pela necessidade de sobrevivência. $O$ trabalho conformase, portanto, como uma instância hierarquicamente superior na escala de valores do processo saúde-doença, que vai ou não conferir a possibilidade de buscar a assistência à saúde. Assim, o que se verifica é que a procura da assistência não é resultado de um processo linear, como um resultado exclusivo das demandas biológicas do doente, e nem depende somente da forma como este entende a doença, mas parece ser intrinsecamente dependente da mobilidade que esse sujeito tem no processo de produção social. Possivelmente são as relações com esse processo que vão determinar uma maior ou menor autonomia, permitindo-lhe dispor de tempo para cuidar de seu corpo, bem como do espaço para vivenciar a doença.

Buscando aprofundar um pouco mais esse tema e apesar de não ter sido explicitado nos achados do presente estudo, não se pode deixar de mencionar o fato de que a busca da assistência à saúde parece estar articulada também à categoria gênero, que explicaria algumas diferenças importantes. HUDELSON (1996), ao se referir a estudo realizado no Nepal, que exibe características bastante distintas do Brasil, procedeu a uma interessante análise sobre os fatores sócio-culturais e sua influência sobre a tuberculose, identificando as interrelações entre a categoria gênero e a procura da assistência. O estudo, realizado com 297 pessoas que apresentavam baciloscopia positiva. constatou que os homens com tosse demoraram em média 27 dias para procurar assistência à saúde, enquanto que as mulheres levaram 49 dias. O autor é cauteloso em não generalizar tais achados, afirmando que as mulheres não podem ser consideradas como um grupo homogêneo, na medida em que existem diferenças importantes que determinam a estratificação e o comportamento dos grupos. Verificou que as mulheres casadas, as que têm filhos em idade pré-escolar, bem como aquelas que trabalham fora de casa não dispõem de tempo para o atendimento de suas demandas de saúde, em decorrência dos novos papéis que vêm sendo assumidos na sociedade. Sem dúvida. esse achado é muito interessante e deve ser interpretado à luz da posição da mulher na sociedade e da forma como a identidade de gênero foi sendo historicamente construida nas diferentes formações sociais. Qualquer outra explicação desconectada desse cenário serviria apenas para uma mera exposição dos fatos e reduziria a análise da realidade. 
Introduzindo outros elementos para uma análise mais totalizadora a respeito da busca da assistência à saúde, mais precisamente sobre o custo da consulta e dos medicamentos, o mesmo autor também verifica que tal elemento configura-se como muito importante na decisão da busca da assistência, fato que não se revelou no presente estudo, possivelmente porque no Brasil o tratamento felizmente ainda permanece prevalentemente no âmbito dos serviços públicos de saúde, que disponibilizam as drogas sem custos diretos para o doente. Entretanto, não se deve esquecer que essa análise também não se deve reduzir ao valor em si do medicamento, mas incorporar outros elementos, como a questão do preço do transporte para dirigir-se à unidade de saúde, além do significado da perda de um dia de trabalho para o doente. Como foi verificado, os sujeitos deste estudo pertencem aos estratos sociais que dependem do rendimento salarial e para os quais, possivelmente, a perda da remuneração de um dia de trabalho produz conseqüências significativas. Mesmo que essas questões não tenham emergido diretamente do discurso dos sujeitos, cumpre mencioná-las aqui quando se faz referência ao Programa de Controle da Tuberculose, uma vez que evidentemente estão associadas ao grau de adesão do doente ao tratamento.

O conteúdo das frases temáticas revela um movimento que impulsiona a pessoa a buscar ajuda no campo da saúde e que este não é um processo fácil de ser levado adiante quando se fala em tuberculose. LEOPARDI (1992), à luz da teoria de Heller, afirma que a procura da assistência configura-se como uma necessidade que, se não satisfeita, pode implicar na limitação da vida em sua plenitude. Como os parâmetros para a definição dessas situações-limite são diferentes para cada individuo e como dependem de sua posição na sociedade e no trabalho, é fundamental entender que, muitas vezes, a demora para a procura da assistência não se deve a uma negligência, conforme muitos parecem sugerir, mas a questões que envolvem o cotidiano dos doentes. Daí que não se pode limitar a questão ao âmbito das decisões individuais, conforme pode ser depreendido do estudo realizado por JOB et al. (1986), realizado em Sorocaba-SP com 50 doentes matriculados em centro de saúde para o tratamento de tuberculose pulmonar. Os autores verificaram que o periodo de tempo decorrido entre o início da sintomatologia e o tratamento foi maior do que dois meses em $60 \%$ dos casos, atribuindo tal demora à falta de motivação para "pedir saúde" (conforme mencionam os autores), explicando sua ocorrência com base na argumentação da "ignorância" (segundo menção dos autores) 
dos pacientes sobre a doença, da falta de educação sanitária ou da dificuldade de cobertura pelos postos de saúde na área. Segundo LEOPARDI (1992) essa tendência de supor que os indivíduos não têm condições de reconhecer as suas próprias necessidades de saúde tem levado a atitudes equivocadas por parte dos profissionais de saúde que preconizam que eles apenas devem ser ensinados a reconhecê-las para satisfazê-las mais adequadamente, segundo critérios e parâmetros que são exteriores às necessidades do próprio indivíduo. Assim é que, via de regra, o que se tem verificado no âmbito dos serviços de saúde, é a definição de intervenções segundo a ótica exclusivamente técnica, alijando o indivíduo doente do processo terapêutico.

Por outro lado, verificou-se que: "a acessibilidade d̀ assistência d̀ saúde determina a sua procura imediata" (11.3). Ou seja, o fato de saber que a unidade de saúde pode albergar a resolução de seus problemas e necessidades faz com que o doente a procure imediatamente após o início dos sinais e sintomas.

Tendo caracterizado o momento da busca da assistência à saúde, explicitando os parâmetros que a determinam, veja-se agora a forma como o doente a percebe. Em primeiro lugar, verificou-se que ainda que a busca da assistência à saúde tenha sido determinada pelo surgimento da sintomatologia, “... ela não é explicitada integralmente, por parte do doente, ao profissional médico" (17.3). Ou seja, o doente intencionalmente não coloca os dados necessários para a compreensão do processo saúde-doença para o profissional de saúde. Essa constatação motiva a indagação se isso não ocorre em função da relação estabelecida com o profissional, ou seja, na perspectiva da existência de espaço para a explicitação das necessidades e problemas de saúde que emanam do doente no momento da consulta médica. O que está aqui em pauta é o fato de que a busca da assistência está diretamente articulada ao conceito de acessibilidade aos serviços de saúde, a qual deve incluir não somente o aspecto geográfico, mas fundamentalmente a disponibilidade dos espaços para que o doente possa explicitar o que sente, vale dizer, as suas necessidades. Isso significa considerar, tal como FRENK (1985), que a questão não se reduz à disponibilidade de recursos de atenção à saúde em determinado local e tempo. mas compreende as facilidades ou dificuldades no seu uso, ao que é necessário acrescentar, o atendimento às carências que o doente apresenta. 
Conforme pôde ser visto no presente estudo, existe um movimento para que o doente busque a satisfação de suas necessidades no âmbito dos serviços de saúde, sendo que, se isso não se efetiva, este procurará outros serviços até que sinta de fato a solução dessa demanda (14.6). Ainda assim, a garantia na consecução da satisfação das necessidades é permeada por outras questões, uma vez que, dada a forma como estão estruturados hoje os processos de trabalho dos profissionais em saúde, bem como devido à configuração do próprio sistema de saúde, a instituição é que acaba por regular a quantidade e a qualidade da oferta dos meios para a satisfação de tais necessidades (LEOPARDI, 1992). Dessa maneira, os anseios do usuário são sistematicamente colocados em segundo lugar, de certa forma refuncionalizados para responder ao que a instituição de saúde compromete-se e pode oferecer em termos de ações de saúde, o que depende muito mais de ações individuais e pouco integradas dos trabalhadores de saúde nos seus processos de trabalho.

Hoje, o Estado carece de um projeto político direcionado à saúde capaz de transformar os perfis epidemiológicos da coletividade. Aqui está se remetendo a questão a um cenário mais amplo no qual, com o esfacelamento do setor público de atenção à saúde, como produto da implementação do modelo econômico fundamentalmente orientado pelo neoliberalismo, o que se tem presenciado é que nos processos de trabalho que têm lugar na produção de serviços de saúde cada vez mais se perde de vista a finalidade maior que é a modificação desses perfis epidemiológicos. Ao invés de se consolidar uma realidade na qual os trabalhadores de saúde estejam cada vez mais comprometidos com o desenvolvimento social e com a busca da eqüidade, o que tem prevalecido são ações fracionadas, que restringem-se ao atendimento da queixa de ordem puramente biológica, sem que outras questões possam aflorar no interior da consulta médica, ou seja, a abordagem da saúde-doença permanece consolidada no âmbito curativo. Não se está querendo aqui imputar aos trabalhadores de saúde a culpabilização por esse processo, mas identificar que há estrangulamentos nítidos na produção dos serviços de saúde, o que determina que de fato, a unidade de saúde acaba por não se configurar como continente às necessidades do doente. Em virtude disso, o doente passa, de certa forma. a selecionar as suas queixas, expondo o que sente em função do que potencialmente pode ter como resposta do serviço de saúde. Um outro ponto que deve ser mencionado é que o conteúdo da frase temática que está sendo analisada remete 
ainda à possibilidade de que também o temor pelo diagnóstico a ser recebido pode determinar com que o doente escolha os sinais e sintomas e apresente somente alguns, na tentativa de evitar a confirmação da doença.

Corroborando o que foi anteriormente dito, verificou-se ainda que: " $a$ 'decepção/frustração' do doente pela conduta médica, no que se refere à valorização da sintomatologia apresentada pregressamente, determina o atraso na busca da assistência à sua saúde" (12.11), o que significa que o doente já havia procurado o serviço de saúde, mas o fato de sentir que suas queixas não foram consideradas fez com que hesitasse ainda mais para buscar assistência que atendesse às suas necessidades. Um outro fato que merece atenção é o de que "o diagnóstico e a necessidade de realização de procedimentos terapêuticos são revelados à familiar (mãe) e não ao doente adulto" (11.5), o que evidencia que a prática em saúde faz desapropriar do doente, aspectos que lhe são particulares e que por isso mesmo deveriam, em primeira instância, ser remetidos à sua pessoa. E, ainda que não dizendo respeito especificamente à motivação para a busca da assistência à saúde, mas na medida em que apresenta conteúdo que se relaciona à frase temática anteriormente apresentada, verificou-se que: “o saber médico não contempla a queixa do doente" (12.12) e "há desvalorização do saber do doente pelo profissional médico na definição do diagnóstico" (14.15).

Essas frases revelam uma dimensão que observa-se, apresenta-se rotineiramente na prestação de serviços de saúde, mas que nem por isso tem sido alvo de mudanças. Ora, o indivíduo que tem uma necessidade de saúde via de regra se apresenta como vulnerável, uma vez que seu corpo, já expropriado de tantas formas, entrega-se aos serviços de saúde. Além de expropriado na sua condição de cidadão, o sujeito torna-se então paciente, submetido à assistência, detentor de um repertório de experiências que em geral não são validadas pelos sistemas estruturados (LEOPARDI, 1992). Há, por assim dizer, a anulação ou a desvalorização de suas crenças, ou queixas por parte da instituição, que vai validar a possibilidade ou não de contemplar os seus sentimentos, bem como as suas carências. Assim, a determinação da necessidade deixa de ser do âmbito do sujeito e é outorgada ao serviço de saúde. 
A desvalorização da queixa do paciente acaba por solidificar a desqualificação das representações que ele tem a respeito de seu próprio corpo e da doença. Assim procedendo, o profissional de saúde reafirma a hegemonia da medicina científica, através da concepção de que ela é a única capaz de decifrar a verdadeira linguagem dos sintomas, de estabelecer as suas ligações com a doença, de restabelecer o equilibrio do organismo e de promover a saúde, em contraposição ao discurso "caótico e desarticulado do doente" (LOYOLA, 1984).

Numa outra perspectiva, pode-se verificar que para o doente, o fato de ter vivenciado a doença/tuberculose parece resultar na incorporação de uma representação sobre esse processo que pode determinar maior rapidez na busca da assistência, que se concretiza através de uma certa prontidão quando da presença de quaisquer sinais e sintomas, que passam então a ser valorizados: "A tuberculose determinou 'prontidão' para a procura de assistência à saúde a partir de sinais e sintomas que anteriormente não eram valorizados ('gripe') $(9.22,15.26)$.

Como pôde ser observado, os parâmetros até aqui descritos, que definem a busca da assistência são bastante variados, sendo dificil determinar o momento em que ocorre a conversão do indivíduo em enfềrmo, no qual o doente se sente suficientemente mobilizado para a procura da assistência ou encontra possibilidades, dentro de seu processo de vida para que isto se configure e possa ser estabelecido como uma necessidade. Assim, além das concepções anteriormente apresentadas, deve ser destacado ainda um outro marcador que possibilitaria para o doente a definição desse instante. Aqui se está fazendo referência a uma outra questão fundamentalmente importante que se relaciona ao ponto até onde o doente consegue desenvolver suas atividades do cotidiano sem sofrer as repercussões do processo de adoecimento ou, conforme aponta HARDY (1994), a definição do momento em que a pessoa se autodefine como enferma. Segundo a autora, é evidente que não existe um limite claro entre o estar doente e o estar são. Ambos os processos são partes de uma totalidade maior que se consubstancia na vida da pessoa e apresentam significados distintos para diferentes sujeitos. Estar são pode significar sentir-se bem - o que é extremamente subjetivo e não mensurável. não apresentar sinais ou sintomas, conseguir desempenhar o trabalho. Mas esses valores mudam segundo a classe social, os aspectos culturais, bem 
como as possibilidades que a pessoa tem de se apresentar ou não como enfềrma à sociedade. Na realidade, parece que essa é a base do processo de decisão sobre o estar ou não doente. Para alguns, o processo começa com uma sensação difusa de mal-estar físico ou mudança da aparência física, que se materializa na diminuição da capacidade para o desempenho das atividades do dia a dia. Daí ser fundamental que o serviço de saúde mostre-se aberto para detectar esses códigos, mesmo que, inicialmente, a aparente desagregação dos sinais e sintomas não evidencie explicitamente a presença da doença, pois esses símbolos muito provavelmente serão diferentes em se tratando da pessoa doente e do profissional de saúde. Este último, em geral, dada a sua formação acadêmica e a forma como tem se constituído a medicina, como campo de conhecimentos e de práticas, concentra sua lógica nas bases clínicas e biológicas para proceder ao diagnóstico e instituir a terapêutica, deixando de lado aspectos que podem ser fundamentalmente importantes para o doente e que se referem ao seu cotidiano (LITTLE, 1995). Partir de uma visão mais alargada sobre o papel dos serviços de saúde proporciona maior acolhimento às necessidades de saúde apresentadas pelos usuários, as quais muitas vezes não se configuram num primeiro momento como demandas explícitas, mas que são inerentes ao processo saúde-enfermidade.

Continuando a desvendar o universo de representações a respeito da assistência prestada, verificou-se que esta, de modo geral, é impessoal, ou seja, o doente refere-se ao profissional de saúde sem fazer uso do seu nome e sem identificá-lo por categoria profissional, utilizando-se simplesmente do pronome 'eles' (1.2).

Além disso, de modo geral está centrada no profissional médico, tanto quando o doente se refere à Unidade Básica de Saúde ou ao hospital:

- "O protagonista da assistência à saúde na UBS é o(a) médico(a) $(2.10,3.21,5.42$, $6.11,7.12,9.24,12.8,14.7)$, denominado(a) (2.10), não denominado(a) " $(3.21,6.11$, 7.12).

- "O protagonista da assistência no âmbito hospitalar é o profissional médico" (8.8, $10.6,11.23,12.3,14.7,15.13,17.9,18.3)$ 
É importante mencionar que alguns doentes fazem referência ao hospital pois chegaram a ficar internados para o esclarecimento do diagnóstico e/ou durante o início do desenvolvimento do tratamento. Um fato que merece atenção se refere à distinção entre a forma como os profissionais de saúde são identificados no âmbito do trabalho da unidade básica de saúde e no nível da unidade hospitalar:

- "A equipe de saúde hospitalar é despersonalizada ('eles'), mas tem categoria profissional definida (assistente social, enfermeira, médico)" (5.18);

- "O protagonista da assistência no âmbito hospitalar é o profissional médico (8.8; $10.6 ; 11.23 ; 12.3 ; 14.7 ; 15.13 ; 17.9 ; 18.3)$, especialista $(14.7)$, denominado (14.7), não denominado (15.13), a assistente social (14.7) e os auxiliares de enfermagem" (12.3).

Isso muito provavelmente ocorre em função da forma como se organiza o trabalho neste último, no qual as categorias profissionais são identificadas pelo doente, diferentemente do que parece ocorrer na UBS. Nesta, as ações dos profissionais diluemse no contexto da assistência, muito possivelmente em função da própria conformação do processo de produção de saúde. Nessa perspectiva, o trabalho desenvolvido por esses profissionais não tem contornos tão nítidos no processo de assistência, não sendo ponto nevrálgico para o doente a função que desenvolvem. Ora, a divisão técnica do trabalho, que tem suas raizes na divisão social do trabalho como fruto da consolidação do sistema capitalista de produção, acabou por constituir uma divisória entre o trabalho tido como intelectual e o trabalho tido como manual. E essa realidade faz-se presente de forma muito mais profunda no ambiente hospitalar, espaço por excelência, no âmbito da saúde, onde reproduzem-se as relações que se dão no plano da produção social. É no interior do hospital que se verifica mais apropriadamente, o fracionamento das funções de cada um dos trabalhadores. Uma vez que o trabalho intelectual foi remetido historicamente para o profissional médico e o trabalho manual, exercido basicamente pela enfermagem, mas também suportado por outros trabalhadores da saúde, revela um produto não imediatamente, o qual não emerge com o mesmo valor para a sociedade que o realizado pelos profissionais médicos. Assim, é evidente que o doente apreenda o trabalho em saúde como desenvolvido basicamente pelos médicos. Estes, supostamente, dispõem de arsenal suficiente para lidar com todas as questões relativas à doença e que para o doente 
se conformam como necessidades mais imediatas a serem resolvidas, com base em concepções de saúde-doença que estão basicamente assentadas na uni ou, quando muito, na multicausalidade.

Assim, não é por acaso que, diferentemente do que ocorreu na UBS, embora com menor expressão do que o profissional médico, no nivel hospitalar, "a enfermeira" também se revela como uma das protagonistas da assistência (18.3). Já no âmbito da UBS, verificou-se que: “a auxiliar de enfermagem é apontada como profissional que diminui a ansiedade, na medida em que orienta sobre o estágio de contágio da doença e sobre o tratamento medicamentoso" (12.6). Como fruto da forma como são organizados os serviços de saúde no país, verifica-se que a profissional enfermeira, ainda que fundamentalmente necessária para desenvolver o trabalho, tem atuado basicamente na instância de gerenciamento da assistência, sendo que a parcela de trabalho historicamente chamada de manual tem sido remetida aos demais integrantes da equipe de enfermagem, principalmente aos auxiliares de enfermagem. E aqui vale a pena resgatar o fato paradoxal de que a assistência à tuberculose começou a se efetivar nos EUA, primeiramente a partir da intervenção das enfermeiras de saúde pública. De igual forma, a enfermagem brasileira, que no seu início reproduziu o padrão norte-americano de assistência, essencialmente, dirigiu o foco de sua atenção para a tuberculose (BARREIRA, 1992; ROSEN, 1994). O que se verifica hoje é a ausência desse profissional no cenário do controle da tuberculose, mostrando uma face bastante diferente da que se fazia presente por ocasião da criação e da implementação da Campanha Nacional de Controle da Tuberculose no país, quando foram sobretudo as enfermeiras que deram corpo às suas ações (BARREIRA, 1992).

No âmbito da UBS, a figura da assistente social é referida pelo doente, provavelmente devido à peculiaridade de seu trabalho, via de regra diretamente articulado ao cotidiano do doente tuberculoso que, em decorrência de suas condições de vida precárias, apresenta necessidades que assumem um valor específico para os doentes, os quais em tese teriam continente em termos de solução e encaminhamento por parte do profissional que lida principalmente com essas questões. Segundo NETTO e CARVALHO (1996), "o assistente social é um dos mediadores privilegiados na relação entre a população dominada. oprimida ou excluída, e o Estado (...) sua especificidade 
está no fato de atuar sobre todas as necessidades humanas de uma dada classe social, ou seja, aquela formada pelos grupos subalternos, pauperizados ou excluídos dos bens, serviços e riquezas...”. Assim verificou-se que: “a assistência na UBS é protagonizada por funcionários (não denominados) $(10.6,15.21)$, sem identificação da categoria profissional ('meninas'), pelos médicos (denominados) e pela assistente social (denominada)" (10.6, 15.21) e que "a disponibilidade da assistente social e o compartir com funcionários da UBS são apontadas como positivas para o seguimento do tratamento" (15.19).

Ainda que raramente, em alguns depoimentos houve menção à equipe de saúde como um todo: "A equipe de saúde é a protagonista da assistência, no âmbito da UBS" (2.50), sendo que a alusão aos diferentes trabalhadores da saúde é feita principalmente quando o doente refere-se ao papel de cada um deles no curso da doença: “...preocupação com o desenvolvimento do processo saúde-doença por parte da equipe de saúde" (2.49). É bastante interessante verificar a forma como o doente percebe-se como receptor da assistência prestada: "o estímulo e o apoio, por parte dos funcionários da UBS, remete à necessidade de gratidão" (10.9), ou: "a gratidão é direcionada em niveis para o divino e para os funcionários da UBS" (10.10). Isso evidencia, por um lado, o encobrimento dos direitos de cidadão pois o doente apreende a assistência ou a cura como dádivas a serem agradecidas. Por outro lado, revela-se que para o doente, o plano espiritual é colocado em primeira instância para a solução do problema da doença, corroborando a função ideológica que assume a espiritualidade nesse processo, a seguir vindo os trabalhadores de saúde.

Cabe observar ainda a forma como o doente entende o seu papel em relação à "missão médica": "O doente remete ao âmbito divino a gratidão para com o profissional médico sob a forma de longevidade e saúde" (18.17). Aparentemente tais anseios de longevidade e saúde conformam-se como os valores mais profundos, radicados na vivência do doente no decurso da enfermidade. A tuberculose. como foi visto anteriormente, traz à superficie a idéia de limitação da vida. Assim, o sentimento mais significativo que o doente pode almejar àquele que o curou só pode ser equiparado à materialidade da vida. 
Quanto aos funcionários, ainda que não sejam identificados pela categoria profissional, o são pelas ações que o doente entende que desenvolvem no interior da UBS: "A assistência na UBS é protagonizada pela profissional médica (denominada) e pelos demais funcionários, sem a definição de sua categoria profissional ('moça que pega a medicação')" (18.3).

Ainda a respeito do profissional médico, foram explicitados alguns elementos que contribuem para conformar a representação que os doentes têm a respeito desse profissional, como "a disponibilidade do médico" (9.26), sendo que "a profissional médica contribui para o tratamento através de estímulo (conversa)" (13.16), ou que o médico é "o agente que diminui a ansiedade ocasionada pelo preconceito da doença/tb e faz modificar o sentimento de morte" (5.25).

Em alguns depoimentos encontrou-se referência explícita à profissional médica, do gênero feminino, caracterizada através de alguns elementos que indicam a valorização do espaço proporcionado por essa profissional durante a consulta ao doente e pelo seu aparente interesse no desenvolvimento da enfermidade, os quais constituem-se como representativos ao doente:

- "A protagonista da assistência à saúde na UBS é a profissional médica (8.7), caracterizada pela etnia (japonesa) $(8.7 ; 17.9)$, denominada (17.9) e qualificada como 'boa' (8.7), por ser 'atenciosa', 'conversar' e por orientar” (17.9);

- "A profissional médica (denominada) é a protagonista da assistência, por proporcionar confiança, permitir a acessibilidade do doente, estimular, mostrar-se disponivel e valorizar a queixa do doente" (4.18).

De modo geral as representações que se referem ao profissional médico evidenciam a expectativa de um tipo ideal de trabalhador de saúde, cuja competência está em "fazer o bem à humanidade e salvar vidas" (14.56) e por isso ele: "é elevado ao status de 'pertencer à familia', devido à importância do seu papel na condução do tratamento" (9.25). 
Essa representação é respaldada pela corrente positivista de pensamento, que compreende a função do médico como apostólica, na medida em que teria o conhecimento suficiente para distinguir com exatidão comportamentos tidos como "certos ou errados", os quais balizariam a elaboração do diagnóstico e da prescrição terapêutica (BALINT, 1957). Essa imagem foi sendo historicamente construída ao longo dos tempos, o que determinou a configuração da profissão médica como hegemônica entre os trabalhadores da saúde, uma vez que aos médicos seria conferida a responsabilidade pelo ato consagrado da definição da doença e instituição do tratamento, que se constituem, na divisão do trabalho em saúde, na parcela relativa ao trabalho intelectual.

Além disso, emergiram representações cujo conteúdo revela a crença de que o médico resolva todos os sinais da doença: "a expectativa do doente em relação ao trabalho do médico é o dever detectar todo tipo de disfunção (emagrecimento) $e$ contorná-lo" (5.28) e, "a expectativa do doente sobre a ação médica é o controle da doença e a prevenção de outras enfermidades" (14.22). Por um lado se verifica a projeção dos desejos do doente em relação à solução das necessidades apresentadas, a partir da forma como a própria medicina foi construindo seu campo de conhecimentos e de práticas, dotando o profissional médico do arsenal para a conversão da doença em cura. Por outro lado, evidencia-se que essas expectativas passam a povoar o imaginário coletivo, tanto dos doentes quanto dos trabalhadores de saúde, em função da ideologia que confere onipotência à medicina ocidental, dado que amparada pelo desenvolvimento tecnológico. E a ruptura dessa expectativa, ocasionada pela “...eclosão de outra doença, concomitantemente à outra já instalada, é entendida como 'negligência médica'," (14.21).

Fica clara a projeção de expectativas das pessoas quanto ao profissional de saúde, transcendendo muitas vezes as questões de cunho biológico ou eminentemente clínico, para integrar um plano que traz à tona questões que dizem respeito ao social, relacionadas ao processo saúde-doença. Entretanto, essas questões podem não ser abordadas, e geralmente não o são, uma vez que o instrumental que detém os trabalhadores de saúde, tanto para o seu entendimento, como para o seu encaminhamento pode ser limitado. Além disso, as próprias concepções que estes têm 
sobre o processo saúde-doença decorrem também de suas visões de mundo, o que acaba por conter a amplitude das intervenções em saúde, uma vez que essas concepções via de regra são respaldadas pelo funcionalismo, que é a corrente de pensamento mais difundida no meio acadêmico e na produção dos serviços de saúde. Quando se trata de entender quais os processos que têm lugar na relação entre o trabalhador de saúde e o doente, uma simples olhadela na literatura em questão possibilita entender que várias têm sido as vertentes de interpretação que tentam explicar a forma como se desenvolve.

Assim, PARSONS (1951), a partir de uma visão fundamentalmente funcionalista, argumentava que o profissional médico tem as seguintes características: é afetivamente neutro, orientado para responder à coletividade, além de ter a capacidade de aplicar universalmente as suas habilidades e conhecimento. Trata-se de uma visão idealista que faz parte do imaginário coletivo e que não dá lugar às tensões no relacionamento entre o médico e o doente. Ademais, ressalta a figura do médico como ser perfeito, apto a lidar com todas as dificuldades que lhe são colocadas. Retira, portanto, o profissional do contexto da sociedade, destacando-o simbolicamente do coletivo. Mas, numa publicação posterior, o mesmo autor admite que o encontro entre o médico e o doente envolve uma estrutura assimétrica, conformada por um componente de autoridade, no qual a hierarquia, o poder e o prestígio social fazem-se presentes. Entretanto, na sua ótica, essa assimetria pode ser convertida em vantagem se o médico utiliza sua autoridade para conseguir a adesão do doente ao regime terapêutico (PARSONS, 1975), o que enfatiza o caráter autoritário desse tipo de visão, uma vez que coloca como legítima a relação que envolve essa modalidade de poder.

ANDERSON e HELM (1979) procedem a uma interessante análise do que denominam como "encontro entre o médico e o doente" que, segundo eles, tem sido examinada, analisada e amplamente debatida desde o início dos anos 50. Consideram que na concepção parsoniana o médico aparece como detentor de conhecimentos, credenciados ou licenciados e portador de competência para lidar com a doença. Deixam claro, entretanto, que tal teoria não leva em conta as questões que se relacionam com o cotidiano, decorrendo a sua limitação quanto ao poder explicativo no que se refere às questões de saúde presentes na realidade objetiva. 
Os mesmos autores colocam ainda que, de modo geral, essas análises que têm suas bases assentadas no funcionalismo, envolvem uma relação que tem como foco a dominação de um sujeito contra o outro. O processo de adesão ao tratamento seria fundamentado nessa perspectiva, pois a natureza científica e objetiva do conhecimento levariam à mistificação da dominação médica, o que resultaria na submissão do doente à ordem médica. Aprofundando essa análise, chegam à conclusão de que, efetivamente, a relação médico-paciente consubstancia um processo de negociação que ocorre num espaço fisico que reforça a dominação do médico sobre o doente, já que a produção dos serviços está organizada de forma a possibilitar prevalentemente o desenvolvimento do trabalho médico, dentro do qual a percepção da realidade pelo doente pode ser ignorada ou negada. Nesse processo, o médico detém os meios para a produção da saúde, ou seja, o local, a retórica, o status social, bem como as estereotipadas concepções sobre a doença, as quais suportam a intervenção sobre o doente. Junta-se a isso o fato de que o doente carrega consigo uma situação que o coloca em desvantagem em relação à sociedade, pelo simples fato de que é portador de uma doença. É nesse cenário que o profissional médico vai determinar o controle sobre todo o processo, que tem inicio a partir do momento em que define o diagnóstico, abarca a extensão do tratamento, a periodicidade dos encontros e forma do seu desenvolvimento, em geral sem que o doente encontre espaço para se posicionar e definir questões que, paradoxalmente. são inerentes à sua vida.

Segundo LEOPARDI (1992), sempre que restrita a fenômenos biológicos, as necessidades de saúde manifestas pelo doente no seu encontro com o médico podem ser resolvidas através de produtos materiais cada vez mais especializados. Isso pode ser verificado nos dias de hoje pela forma como a medicina tem atendido às demandas de saúde, ao medicalizar e tecnologizar o processo saúde-doença. Porém, ao se observar a questão com "olhos mais largos" (expressão da autora), envolvendo desde padrões culturais, como a sociabilidade e o psiquismo, verifica-se a necessidade de uma compreensão mais totalizante, fundamental na adesão do cliente ao tratamento.

MERHY (1996), também à luz dos fundamentos de Heller, analisa a questão sob a ótica do processo de produção de serviços. Na etapa relativa à intervenção tecnológica e assistencial, o autor afirma que "...concretiza-se um trabalho que toma centralmente 
um conjunto de sabedorias e de práticas com a finalidade de realizar uma intervenção sobre um certo problema de saúde, conforme os critérios adotados pelo modelo de atenção do serviço (...) e que visa ou alterar (...) o sofrimento representado como problema de saúde pelo usuário, ou alterar o seu percurso no individuo ou no coletivo, ou mesmo alterar a sua produção ao nível do conjunto das relações sociais". Com isso, adota a perspectiva de que a ação do trabalhador de saúde é focalizada e orientada para o recorte que o doente apresenta sobre o seu processo saúde-doença, devidamente reinterpretado pelo trabalhador de saúde.

A compreensão do que ocorre com a relação médico-paciente deve também levar em conta outras questões que recentemente têm ficado cada vez mais explícitas, face à falência do atual sistema econômico, possibilitando a compreensão das práticas de saúde a partir de outros ângulos de análise. Assim, se esta relação não for remetida à forma como estão estabelecidas as políticas de saúde no país, pode-se incorrer no risco de imputar a falta de satisfação das necessidades do usuário somente ao trabalhador de saúde. Na verdade, há forças estabelecidas também sobre a ação desses sujeitos que, dependendo da sua mobilidade no processo de produção social, também estão expostos à situação de exploração no trabalho. Não se está justificando com isso a forma como esses trabalhadores desenvolvem as práticas de assistência, mas buscando elementos para entender como esse cenário sobredetermina a ação dos trabalhadores de saúde. É evidente que as intervenções desenvolvidas por esses trabalhadores não devem deixar de lado o cumprimento dos princípios da universalidade, da eqüidade, do acesso, que buscam preservar a ideologia da defesa da vida. Assim, a compreensão da forma como se processam e se constituem as necessidades de saúde dos indivíduos e da coletividade. bem como o compromisso e os valores éticos do trabalhador de saúde com a prestação da assistência à saúde demandariam um fazer diferenciado que poderia ancorar o doente à unidade de saúde, garantindo-lhe um espaço onde explicitar suas necessidades e possibilitando que a adesão se configure como uma etapa desse processo.

Conforme MENDES-GONÇALVES (1992), o trabalho em saúde não pode ser tomado como mercadoria de forma imediata, na medida em que não produz bens materiais imediatos que servem como meio de produção de mais-valia e acumulação de capital. O trabalho em saúde produz resultados que correspondem à reprodução das 
necessidades do homem, as quais são social e historicamente determinadas. Na esteira do capitalismo, o trabalho em saúde visa o controle da doença, bem como a recuperação da força de trabalho, deixando de valorizar a esfera das necessidades peculiares dos indivíduos no âmbito do cotidiano. ANDERSON e HELM (1979) lembram que para o médico, o encontro com o doente constitui apenas uma rotina, mais um "caso" a ser resolvido, freqüentemente tido como "normal" ou "típico", enqüanto que para o doente, a doença configura-se como uma experiência excepcional, imediata, pessoal e subjetiva, freqüentemente um motivo de apreensão que, dependendo do veredicto a ser dado pelo médico, pode modificar sua vida.

Ilustrando alguns pontos anteriormente discutidos, a expectativa do doente sobre a intervenção realizada pelo serviço de saúde, em geral personificada pelo médico, é baseada no saber que este detém sobre a enfermidade, tanto no que se refere ao seu curso normal, como em relação ao tratamento $(18.15,18.16)$, sendo que: “...o profissional médico 'descobre o que se tem', ajuda e orienta" (8.20).

Observou-se também que as orientações médicas dizem respeito a condutas que se concentram na necessidade de "não transmissão da doença, além da necessidade de seguir o tratamento medicamentoso" $(14.43,17.10)$. Veja-se que está explícita a idéia de que o tratamento medicamentoso é necessário, bem como: “... o esclarecimento de que a melhora da sintomatologia não traduz a cura e salienta que o seguimento do tratamento leva a uma possibilidade de normalização da vida" (7.13; 17.10), questões que são fundamentalmente importantes para que o doente dê continuidade ao tratamento, ou seja, verifica-se que essas idéias foram incorporadas pelo sujeito ao seu cotidiano, determinando inclusive, com que leve uma vida regular, ainda que atrelada ao uso dos medicamentos. O que parece ficar claro é que existe um esforço do profissional de saúde para que tanto a doença, como a regularidade na ingestão dos medicamentos sejam tomadas como fatos regulares, incorporados no dia-a-dia.

Ainda no que se refere à expectativa do doente em relação ao médico, é interessante verificar a forma como o doente percebe o apoio desse trabalhador durante a assistência: "O estimulo do profissional médico é caracterizado como 'conversa' 
(durante o exame fisico) e de 'tornar normal o processo da doença', apesar da sua pequena disponibilidade de tempo durante a consulta médica" (17.30).

JOHNSTON e WILDRICK (1974) já enfatizavam que o momento em que o doente se encontra na unidade de saúde deve ser aproveitado para que se proporcionem ações de cunho educativo e de aconselhamento aos doentes para que estes possam entender a sua doença, o seu tratamento, bem como buscar entender os eventuais aspectos relacionados à vida do doente que poderiam levar ao abandono do tratamento. O que parece ocorrer é que de fato, não se considera, no âmbito dos serviços de saúde que as queixas, os problemas apresentados pelos doentes se constituem em necessidades contextualizadas cultural e socialmente segundo o locus em que eles se encontram inseridos na sociedade.

Segundo MERHY (1996), no momento em que se estabelece um espaço de escuta entre o usuário e o trabalhador de saúde dá-se início a um processo de trabalho em saúde, cujo objetivo é modificar a necessidade manifesta pelo doente. O profissional de saúde, principalmente o médico, detém o poder de normatizar a vida do doente. Ou seja, o saber técnico de que se vale esse profissional é incorporado pelo doente como aquele que vai orientar o seu movimento no espaço da vida, através de um conjunto de regras. Assim, o doente sujeita-se a esse novo padrão, incorporando tais regras ao seu cotidiano, pois: "o diagnóstico é tomado sob a forma de "obediência" à palavra do profissional médico" (18.8).

Entretanto, essa atitude não parece ser tomada de forma tão linear, na medida em que apresenta-se associada a uma dimensão que se refere ao seu relacionamento com o trabalhador de saúde: "O cumprimento da ordem médica depende da relação médicopaciente" (12.23). Verifica-se, portanto, que a efetivação das ordens médicas depende da dinâmica que se instaura no âmbito da consulta médica, que pode determinar diferentes posturas do doente, não só em relação à doença, mas também em relação ao tratamento, incluindo a questão relativa à adesão. É importante destacar, por outro lado, que isso pode não garantir a efetividade da adesão, uma vez que muitas vezes o abandono deve-se imediatamente a questões sociais que impedem de início que o doente chegue até a unidade de saúde. Assim, a análise da adesão deve levar em conta essa 
outra face que revela o cotidiano da sociedade brasileira hoje, no interior da qual multiplicam-se aqueles que não conseguem nem ao menos apresentar a saúde como necessidade.

Cabe destacar, por outro lado, uma outra representação que revela a distância efetiva que existe entre o profissional de saúde e o doente, conforme evidenciado pela frase temática a seguir, em que o último, na falta de informações sobre o diagnóstico, passa a buscá-las "junto à assistente social e não ao médico, qualificado como 'amigo'" (14.29). Ou seja, o espaço para a discussão sobre a sua enfermidade não se concretiza junto com o médico, que define o diagnóstico, estabelece a terapêutica e é instituido como "amigo", mas sim no âmbito da relação com o profissional que no processo de produção de serviços é possivelmente responsável por lidar com as contradições inerentes à equação adoecimento versus necessidade de produzir para a reprodução social, concretizada na necessidade de viver.

Frente as transformações no modo de produção e o desenvolvimento da tecnologia em saúde, configurados na forma como se constitui hoje o trabalho em saúde, o ato médico cada vez mais se consubstancia como uma série de diagnósticos operacionais, conforme coloca ROSA (1991), resultado de uma leitura parcial da história clínica do indivíduo e que promovem mais uma situação favorável à demanda de medicamentos do que à produção de conhecimentos sobre os problemas colocados pelos usuários dos serviços de saúde e pela intervenção sobre eles. Como resultado, intensifica-se uma certa forma de trabalho que é transmitida e incorporada pelo doente, que passa a ter concepções da assistência a partir dessa ótica. Dessa forma, explicam-se os resultados encontrados por LOYOLA (1984) na região periférica do Rio de Janeiro, em que a clientela estudada, por conseqüência de uma dada inserção social, em geral apresentava uma atitude peculiar em relação ao profissional médico. Ao contrário do que muitos supõem, para esse grupo de pessoas, o médico não era considerado como o detentor de um saber legítimo, mas como um simples provedor de medicamentos.

Ainda no que se relaciona à forma como os pacientes percebem a assistência, a frase temática que se verifica a seguir é ilustrativa do fato de que para o doente a ação médica parece estar limitada a uma série de procedimentos que, possivelmente, se fazem 
significativos, ou seja, o que se configura como fundamental no momento da consulta médica para o doente parece ser o ato terapêutico, que é posto em relevo em relação à consulta como um todo, mesmo que esta integre a anamnese, o exame físico, a prescrição da terapêutica, além das orientações para a sua realização. Veja-se, por exemplo, a forma como o doente percebe o trabalho médico desenvolvido no âmbito hospitalar: "O protagonista da assistência no âmbito hospitalar é o profissional médico, cuja ação se restringe à prescrição de medicamentos e encaminhamentos " (8.8). É evidente que há distinções entre o processo de produção que tem curso no hospital e o que ocorre na unidade básica de saúde. Entretanto, fica claro que a finalidade do trabalho que seria a transformação da necessidade que se configura como doença para a possibilidade de poder viver sem as repercussões da enfermidade, é apreendida pelo doente somente a partir da ação objetiva do profissional médico, que se consubstancia na prescrição terapêutica. A representação simbólica que tem o medicamento para o doente e para o trabalhador de saúde são absolutamente diferentes. Para o doente, na medida em que considere a saúde-doença de importância para a sua vida, considerará o medicamento como um valor de uso e, portanto, como uma necessidade, enquanto que o trabalhador de saúde tem o medicamento como um meio para a produção da saúde.

No que se refere à forma como as pessoas concebem o diagnóstico médico verificou-se que este "é pautado pelo resultado do exame de escarro" (1.8); "sangue e urina" (2.7), sendo que as representações encontradas parecem indicar que " $a$ realização de exames é fundamental para orientar a prescrição médica" (2.11). Da mesma forma, "para o doente, o raio-x é um parâmetro do seu estado/situação em relação à doença/tb" (2.53), sendo que para ele existe diferenciação entre as finalidades dos exames, pois: "o raio-x reflete a noção de gravidade da doença/tb e o exame de escarro evidencia o diagnóstico" (5.9) e, “o diagnóstico de tuberculose é definido através de exame especifico (biópsia de pleura)" (12.4).

O exame radiológico não é o mais indicado para revelar o diagnóstico da tuberculose (CORPE, 1972), mas constitui-se em instrumento extremamente utilizado na assistência, para a avaliação do grau de comprometimento e a evolução da doença durante o tratamento. Para o doente, o raio-x se presta à definição da gravidade da 
doença. Isso de certa forma reproduz a imagem da doença que o profissional de saúde transmite ao usuário, através de símbolo representacional que evidenciaria o estado de comprometimento e de complexidade de sua enfermidade: "a profissional médica evidencia a doençaltb através de imagens ('crateras')" (17.11). Nessa frase temática está implícita a idéia de situação-limite que é tomada pelo médico, possivelmente para mostrar o estado de perigo em que o doente se encontra. Tanto a prática assistencial como o próprio aporte teórico da medicina podem utilizar como ferramentas, imagens características de emergência e/ou de anormalidade do funcionamento do corpo humano para convencer os doentes da necessidade do cuidado à saúde. Ao invés da difusão de conhecimento, para sensibilizar e conscientizar para o cuidado e a atenção ao corpo, essas ações podem levar a um estado de alarme que contribui para aprofundar o desconhecimento em relação ao que se passa com o organismo. Isso pode ser evidenciado em: "A representação da doença/tb que é veiculada pelo profissional médico, provoca sensação de 'arrepio' no doente" (17.12), sentimento que pouco contribui para que a pessoa enferma se conscientize sobre o seu processo saúde-doença.

Uma outra representação a mencionar foi a de que: "o conjunto de sinais $e$ sintomas determina a solicitação de teste de $H I V^{\prime \prime}(2.8)$, na qual se verifica que o doente percebe a existência do vínculo entre a AIDS e a tuberculose, questão que deve ser cada vez mais abordada no âmbito dos serviços de saúde pois se constitui em uma realidade para a qual possivelmente o doente não se encontra preparado para incorporar ao seu cotidiano dada a situação de fatalidade que permeia a AIDS (TAKAHASHI, 1997).

Ainda no que se refere ao diagnóstico, o doente percebe que este é efetivado pelo médico, "a partir de poucas perguntas" (14.4), observando-se também o fato de que "os procedimentos de isolamento e a prescrição de medicamentos são transmitidos ao doente, mas o diagnóstico não é comunicado" (14.24), ou ainda: "o profissional médico reduz sua orientação específica ao doente, ao controle dos comunicantes ('fazer exame')" (5.24). Via de regra as orientações que mais são incorporadas pelos doentes parecem ser aquelas que de alguma forma referem-se à transmissão da doença, como: "as orientações médicas esclarecem sobre o modo de transmissão da doença/tb e sobre a indiscriminação de sua transmissão" (17.13), ou: "há ausência de orientações pelo 
profissional médico quanto ao modo de transmissão da doença/tb" (3.9). O que parece ficar evidente é que essa questão da transmissão adquire tal significado para o doente que acaba por se constituir em um dos núcleos fundamentais das representações sobre a doença que tem lugar em conjunto com a questão relativa ao preconceito e com as conseqüências emanadas da necessidade de interrupção das atividades do cotidiano.

Além desse tipo de preocupação que parece ser incorporada ao ideário do doente, emergiu uma outra representação de suma importância: "a orientação médica aponta para a necessidade de ...que a doença não provoque auto-comiseração" (7.13), o que mais uma vez reflete a postura médica em relação à doença, ou seja, de que ela deve ser tomada como um fato regular na vida do doente. Parece existir, por parte do profissional de saúde, uma tendência à naturalização do fenômeno doença para que seja tomado como normal pelo sujeito. Tal contradição muito provavelmente explica a postura do profissional que, incapaz de lidar com a doença como um processo que transcende o biológico e que traz profundas implicações para a vida do doente, orienta as condutas e a postura do doente em direção a uma experiência com a doença que deve ser tomada no âmbito da normalidade. Em virtude disso, tenta manejá-la como um processo natural e, conforme considera CRAWFORD (1980), reforçando a sua compartimentalização, transformando a doença em uma propriedade de cunho individual, o que isentaria a sua interpretação no espaço social, político e contextual no interior do qual vive o indivíduo. Nesse sentido, a necessidade de uma resposta terapêutica para a experiência individual da doença se tornaria o campo onde as relações sociais seriam reproduzidas e sobre o qual as informações seriam selecionadas e autoritariamente comunicadas.

Uma outra representação que ajuda a conformar a imagem da assistência para o doente refere-se à UBS, que é apreendida como: "um local de distribuição de medicamentos" $(5.20,18.14)$. Os conteúdos das representações anteriores já haviam colocado em relevo a forma como a assistência é visualizada no interior desse locus de produção de serviços, revelando a existência de ações pontuais que reduzem a intervenção em saúde coletiva. Ainda que restrita a algumas atividades, a atuação da unidade de saúde é tida pelos doentes como "importante", pois "estabelece o diagnóstico e prescreve os medicamentos" (3.19). 
$O$ conteúdo representacional das frases temáticas anteriormente citadas mostra uma face da assistência em que a consulta médica aparece limitada a um pequeno interrogatório, seguido de algumas recomendações relacionadas ao isolamento, ao controle dos comunicantes e à terapêutica, sem que se efetive a troca de informações sobre o diagnóstico ou então esta é pouco recordada pelo doente. É interessante lembrar que essas representações perfazem o universo das pessoas que participaram do presente estudo, que aderiram ao tratamento. Pergunta-se então, de que forma aqueles que apresentam dificuldade na adesão ao serviço concebem o papel da unidade de saúde. Se as questões fundamentais que poderiam contribuir para facilitar a adesão dos pacientes ao Programa de Controle da Tuberculose não são trabalhadas no cotidiano daqueles que cumprem o tratamento, indaga-se como se operacionaliza a assistência para aqueles que constituem o nó crítico em termos de alvo dos programas de controle. Ou seja, parece ficar evidente que o estrangulamento do Programa de Controle ocorre já no interior da unidade de saúde, também no momento da consulta médica. Esta é tida historicamente como etapa ímpar da assistência, em que se efetivam ações de fundamental importância, como o exame físico, a decodificação deste em diagnóstico e a prescrição da terapêutica. A consulta parece que nem sempre vem cumprindo a sua função, como um momento por excelência para o estabelecimento de uma relação entre o profissional de saúde e o doente que redunde no atendimento aos carecimentos deste último. Na realidade, o que se verifica é uma focalização dos atos médicos sobre a doença em busca de uma relação de causa-efeito, sem que possa ter lugar outro tipo de abordagem que se refira, por exemplo, ao processo singular de vivenciamento da doença. Evidencia-se que o processo de trabalho em saúde está pautado ideologicamente no paradigma racional doença-cura, que limita a proposição de intervenções que respondam efetivamente às necessidades de saúde dos diversos grupos sociais. As questões sociais são apreendidas como mais um componente, um fator ou elemento no rol das possíveis causas da doença, não levando em conta a determinação social da saúde-doença como uma vertente explicativa do fenômeno. E o que se verifica é que essas outras questões passam ao largo da assistência, sem que ao menos ocorra a chance de serem decodificadas como necessidades de saúde. Se o são, isso ocorre de forma tal a transformá-las em idiossincrasias do indivíduo e, portanto, fora do âmbito de ação dos profissionais de 
saúde, que assim imputam ao doente toda a responsabilidade pelo seu processo saúdedoença.

Segundo KANTORSKI (1997), esse raciocínio doença-cura, da onipotência virtual da técnica e da qualificação de apenas alguns tem conduzido a uma crescente desumanização das relações sociais e, por extensão, das relações entre o trabalhador de saúde e o doente. Essa desumanização origina-se na alienação, pois o homem não se reconhece mais no produto do seu trabalho, não contribuindo para a satisfação das suas necessidades, como trabalhador de saúde, e ainda menos para a satisfação das necessidades de saúde dos doentes.

A mesma autora advoga a necessidade de mudança desse paradigma, reorientando-o para o cuidado em saúde, que se consubstanciaria como um eixo sobre o qual se poderia construir uma transformação cultural das relações sociais no trabalho em saúde, para modificar a prática vigente nos serviços desse campo. Esse novo paradigma seria fundamentado sobre as condições materiais de existência e de configuração do processo saúde-doença, buscando a integralidade do sujeito, o que marcaria a definição de um novo modelo de assistência à saúde. Tal proposta está respaldada por CAMPOS (1992), para quem esse novo modelo assistencial baseia-se na acolhida e na responsabilização dos trabalhadores de saúde pelos doentes, tomando-os como alvo da prática da assistência.

O doente apreende ainda que a ação do profissional de saúde está associada a uma projeção em relação ao seu pensar e agir: "a expectativa do profissional de saúde (assistente social) é que o doente, devido à sua diferenciação social, não deixe que a doença/tb atinja a situação-limite ('escarrar sangue')" (5.31). Vê-se que o profissional de saúde atribui ao doente tanto a responsabilidade pela sua saúde a partir da sua diferenciação social, que determinaria, na ótica do profissional de saúde, um comportamento diversificado no cuidado com o corpo. McINTOSH (1974), discutindo a relação entre os profissionais de saúde e os doentes portadores de câncer, verificou que o trabalhador de saúde, em função da percepção da diferenciação sócio-econômica do doente, baliza as possibilidades de compreensão dos doentes em relação ao processo saúde-doença, como também define e restringe o montante de informação sobre a 
doença a ser transmitido ao doente. Isso proporciona o falso álibi de prover informações sobre saúde para aqueles com capacidade de absorção, o que não deixa de ser uma operação altamente ideologizada. Da mesma forma, justifica que ações que envolvem um entendimento supostamente diferenciado efetivem-se somente para aqueles que detém essa capacidade, o que configura uma situação de iniqüidade no acesso às ações de saúde.

Ressalta-se o conteúdo das frases temáticas a seguir relacionadas que explicitam a forma como o doente percebe a organização dos serviços de saúde: "a necessidade de freqüentar as consultas médicas é apontada como fator negativo para o doente" (15.18); "a mudança da equipe de saúde na UBS é apontada como negativa no seguimento do tratamento, na medida em que promove o distanciamento da nova equipe, no relacionamento com o doente" (15.20) e, "o vínculo do doente com a UBS é rompido com a implementação do $P A S^{\star}$, uma vez que provoca a mudança da equipe de saúde" (15.22). O conteúdo representacional das frases anteriormente apresentadas revela questões extremamente importantes que evidenciam, em primeiro lugar, que o fato de ter que freqüentar a unidade de saúde não se configura como algo regular para o doente, como também não se configurava a busca da assistência. Além disso, fica claro que o vínculo que se estabelece com a equipe de saúde é fundamental para garantir a proximidade do doente com o serviço. Mas essa possibilidade tem sido cada vez mais longínqüa, pois o processo de deterioração que vem sofrendo os serviços de saúde vem resultando, dentre outras conseqüências, na altíssima rotatividade dos trabalhadores desse setor, o que torna manifestos alguns pontos de estrangulamento que contribuem para a ruptura da relação do doente com o serviço de saúde. Ressalta-se ainda que um dos fatos ocorridos no Município de São Paulo, que sofreu a implementação do Plano de Assistência à Saúde a partir do ano de 1995, determinou com que os programas de saúde fossem quase que totalmente destruídos, uma vez que se estabeleceram cooperativas médicas que passaram a atuar com uma lógica bastante diversa daquela que nutria $o$ desenvolvimento desses programas. Em decorrência, no início de sua operacionalização, os doentes com tuberculose foram pulverizados para as unidades de saúde da esfera do

\footnotetext{
${ }^{4}$ Plano de Atendimento à Saúde, introduzido na Gestão Administrativa da Prefeitura do Municipio de São Paulo, no ano de 1995.
} 
Estado de São Paulo, sem garantia de que fossem efetivamente incorporados ao atendimento. Durante a etapa relativa à coleta de dados do presente estudo, houve a oportunidade da pesquisadora sentir os efeitos desse processo, quando por exemplo, ao realizar visita para entrevistar uma pessoa, esta relatou presença de sinais e sintomas compatíveis com a tuberculose e que não tinha dado continuidade ao seu tratamento, uma vez que havia sofrido desligamento do programa da unidade de saúde que pertencia à Prefeitura do Municipio. A não garantia de sua incorporação na unidade do Estado de São Paulo fez resultar no abandono do seu tratamento.

HELLER (1991) chama a atenção para o fato de que a vida cotidiana está profundamente influenciada pelas transformações econômicas e políticas. Dessa forma, mais uma vez ressalta-se a necessidade de se proceder a análises estruturais com referência ao Programa de Controle da Tuberculose, uma vez que a reorientação das políticas públicas em função do modelo econômico que vem sendo adotado, certamente repercute não somente na determinação da doença mas também na forma como os sujeitos poderão encontrar espaço para dar encaminhamento às necessidades. A adesão neste caso, está intimamente relacionada ao processo de produção da saúde e mais uma vez não se remete somente ao âmbito estritamente individual.

Um outro ponto que emergiu dos depoimentos dos doentes e que em parte já foi discutido quando o que estava em pauta era a questão relativa à forma como se processou a busca da assistência refere-se à acessibilidade. Ainda que na Carta Constitucional do país esteja declarado o acesso como eqüitativo, na prática o que se tem verificado é que a sua consecução está permeada por uma série de dificuldades. A negação do acesso ao atendimento, ao medicamento, aos exames laboratoriais, à qualidade, à satisfação das necessidades que traz o usuário, todas essas se constituem, em última instância, em negação do cliente propriamente dito. E é por isso que aqui está se remetendo a uma concepção ampliada sobre o acesso, tendo como referência primeira o conceito de saúde explicitado na Lei que estabelece o Sistema Único de Saúde, que se constitui no pilar de estruturação do sistema de organização da saúde no país (BRASIL, 1992). 
Dentro dessa perspectiva mais totalizadora, o conceito deve estar articulado a processos que transcendem ao fenômeno biológico. Sendo assim, a definição de acesso não se reduz à distância a ser percorrida pelo paciente até a unidade básica de saúde, nem tampouco ao periodo de tempo até que seja atendido, mas refere-se sobretudo à possibilidade efetiva de ter suas demandas atendidas. No presente estudo verificou-se que essa questão se configurou com um problema pois as pessoas referiram um contexto que se desenha como: 'sem atendimento', 'sem funcionários', 'demora' (9.8); “há dificuldade de acessibilidade ao serviço para o diagnóstico da doença/tb (8 unidades percorridas)" (3.3); "a busca da assistência à saúde evidencia 'peregrinação' em função da falta de profissionais, falta de 'vaga' $e$ da necessidade de 'guias' do convênio" (5.3).

Com a descontinuidade do Programa de Controle da Tuberculose nos estados e municípios, tanto os profissionais de saúde deixaram de ser preparados para diagnosticar e tratar corretamente a doença, como as próprias unidades públicas de saúde ficaram impossibilitadas de responder às demandas inerentes aos pacientes portadores deste tipo de agravo. Isso sem mencionar as instituições privadas de saúde, que carecem de qualquer tipo de controle no que se refere às ações dirigidas à enfermidade.

$\mathrm{Na}$ medida em que as suas necessidades não são atendidas, os doentes de modo geral remetem a responsabilidade por esses problemas ao plano que conhecem, ou seja, imputam linearmente as conseqüências da precariedade da prestação de serviços de saúde aos trabalhadores de saúde: “ $O$ doente manifesta sentimento negativo em relação aos funcionários da UBS, uma vez que controlam o acesso (número de vagas) dos doentes à unidade de saúde" (17.18). Nesse caso, a responsabilidade pela organização dos serviços é remetida aos trabalhadores de saúde, em geral os auxiliares de enfermagem, que constituem a linha de frente em termos de contato com os doentes. $O$ doente acaba por remeter a sua crítica aos trabalhadores menos qualificados, com os quais estabelecem uma relação de poder, ainda que também assimétrica, um pouco mais igualitária do que aquela que ocorre com os profissionais de nível superior.

Há uma série de barreiras estabelecidas pelo próprio serviço de saúde que acabam por dificultar o acesso do doente em busca do atendimento de suas demandas. $\mathrm{Na}$ 
realidade, a oferta das ações de saúde parece ser estabelecida a priori e à parte das necessidades dos doentes. Segundo MERHY (1996), na produção dos serviços de saúde, no que concerne à etapa relativa à recepção do doente na unidade de saúde, ocorre um momento de tomada de decisão no qual se operacionalizam os critérios que definem se o que o usuário traz ao serviço pode ser definido como um problema de saúde, ou seja, como um objeto de ação do serviço, enquanto uma intervenção tecno-assistencial. Nesse momento de "argüição", o trabalhador de saúde decidirá sobre a trajetória do usuário: se prosseguirá na próxima etapa do processo de trabalho a ser realizado dentro do próprio serviço, que corresponde à da intervenção tecnológica em saúde propriamente dita, se irá para outro serviço, ou se simplesmente lhe será negada qualquer alternativa de assistência. Segundo o autor, tais critérios dão um certo sentido e concretude ao conceito de necessidade de saúde com o qual o serviço opera. Para o doente, a necessidade de saúde é representada e sentida nesse momento como um problema que ele vive, "como um sofrimento, ou risco de sofrimento, e que ele traduz como uma questão de saúde, a ser enfrentada com a ajuda de alguém ...".

Ora, romper com a estrutura rígida que condiciona a oferta dos serviços de saúde é uma questão ainda a ser equacionada na assistência à saúde. Enquanto os serviços de saúde se comportarem como estruturas fechadas que se relacionam com os clientes somente para a prestação dos serviços e não para acolher suas demandas, o que se constitui na verdadeira finalidade de sua existência, haverá um distanciamento entre as carências dos sujeitos e a finalidade dos processos de trabalho dos profissionais da saúde, qual seja a da transformação dos perfis epidemiológicos. O que aqui se está ressaltando é a necessidade de que o serviço de saúde albergue efetivamente as demandas de saúde do doente. Em certo sentido, é possível tomar emprestado de MERHY (1996) o conceito de acolhimento: “...escutar, trocar informações e decidir rumos para dar uma resposta tecno-assistencial ao problema apresentado - na maneira como se compromete e se responsabiliza por eles, na forma como coletivamente trocam suas sabedorias...".

Ainda com respeito à questão da acessibilidade, verificou-se que: "a necessidade de realização de exames e de apresentação de 'documentos' provoca a demora no início do tratamento (um mês)" (4.5). Em termos práticos, isso pode significar que esse paciente prolongou seu período de transmissibilidade por 30 dias, além de ter sido alvo 
do sofrimento em virtude do desenvolvimento da doença, com todas as implicações que podem ter lugar. O que fica bastante evidente nesta frase é o fato de que muitas vezes a dinâmica instaurada nos serviços de saúde está presa a determinadas ações de caráter burocrático que podem contribuir para o estrangulamento do programa de controle da doença, além de comprometer seriamente o processo de adesão do cliente ao tratamento. Em doenças que exibem progressão contínua como a tuberculose, há que se estabelecer um processo de atendimento no qual a agilidade na recepção do doente ao serviço seja um dos principais pilares de intervenção. Assim, conforme verificou-se em um depoimento, quando a tuberculose foi o motivo pelo qual o paciente procurou a unidade de saúde, $o$ atendimento ocorreu sem que alguns passos usuais na assistência tivessem que ser percorridos pelo doente: "a doença/tb provoca discriminação que, paralelamente, garante na UBS, prioridade no atendimento" $(4.36,5.4)$.

Ressalta-se ainda a série de passos que muitas vezes o paciente é obrigado a trilhar, na perspectiva da conquista da assistência à saúde, como ilustram as frases seguintes: "o acesso à internação depende da comprovação de residência na área geográfica do hospital e se constitui em obstáculo a ser transposto pelo doente, apesar da determinação médica" (14.9). Ou: "a assistência no hospital do convênio se concretiza somente a partir da insistência do doente" (5.8).

Vale a pena analisar as repercussões de fatos como anteriormente mencionados. A internação, embora sendo uma necessidade determinada pelo médico que trabalha na instituição hospitalar, depende da intervenção do doente para ser obtida. Ressalta-se a dicotomia entre as ações de administração do serviço e aquelas relativas à assistência propriamente dita, o que coloca em evidência a fragilidade em termos de organização do sistema de atenção à saúde. Isso ainda pode ser corroborado através da seguinte frase " $a$ infra-estrutura hospitalar não permite o cumprimento do tratamento durante a internação (banho: água fria no $H U^{5}$ )" (14.12). Ou seja, a assistência deixa de garantir o mínimo em termos de satisfação de necessidades do doente, na medida em que num hospital do porte e importância que tem o Hospital Universitário, em São Paulo, há precariedade de instalações para suportar a estadia do doente.

\footnotetext{
${ }^{5}$ HU: Hospital Universitário da Universidade de São Paulo
} 
Ainda com referência à questão do acesso, destaca-se a importância do conteúdo representacional da frase seguinte: "A morosidade na assistência em São Paulo provoca busca de assistência à saúde em outro Estado" (6.2). O que chama a atenção nessa frase é o fato de que se está falando de um país de dimensões continentais, em que buscar assistência à saúde em outro Estado significa viajar, no mínimo, dezenas de quilômetros, dispendendo tempo, possibilitando a disseminação da doença e contribuindo para o agravamento da enfermidade no indivíduo. Esse caso em particular refere-se a um paciente que foi buscar assistência no estado de Pernambuco, mais especificamente na cidade de Recife, devido à lentidão na obtenção de assistência no Município de São Paulo que, supostamente, deveria apresentar um padrão de estruturação dos serviços de saúde superior a outras localidades. O conteúdo representacional da frase temática anteriormente destacada fere os princípios que constituem-se em pilares do sistema de saúde brasileiro, os quais se referem à regionalização e à descentralização dos serviços de saúde (BRASIL, 1992).

Apesar de se tratar de uma realidade totalmente distinta da brasileira, MARTINY et al. (1992) resgatam essa questão ao descreverem o programa de controle da tuberculose na Nigéria. Esse programa foi descentralizado para ser efetivado nas unidades de saúde mais periféricas, desde o ano de 1985. Dessa data até a época em que foi publicado o relato, os autores verificaram que a taxa de abandono ao programa foi reduzida de 42 para 19\%, o que os faz advogar em defesa do processo de descentralização do atendimento para unidades de saúde próximas às localidades onde vivem os pacientes.

Ainda a esse respeito, vale comentar o estudo conduzido por WILKINSON (1994) em região rural da África do Sul, no início da década de 90, no qual o tratamento intermitente, administrado duas vezes por semana sob supervisão, foi realizado. Através da abertura de "micro-postos" regionalizados para a distribuição de medicamentos, a administração das drogas era feita sob supervisão de pessoas da própria comunidade, os quais eram por sua vez monitorados mensalmente por profissionais de saúde. $O$ autor destaca a importância de realizar intervenções na própria comunidade, de modo a resguardar sobretudo a conveniência do próprio doente. Esses micro-postos de distribuição foram escolhidos na região geográfica onde se encontravam os pacientes. 
Todos os supervisores observavam a tomada dos medicamentos e procediam a uma avaliação concisa do quadro apresentado pelos doentes, a qual era anotada subseqüentemente. $\mathrm{O}$ autor destaca que as pessoas que "supervisionavam" o tratamento, em sua maioria não eram profissionais de saúde (52\%) e nem eram pagos para tal. De uma taxa inicial de tratamentos completados de $18 \%$, verificou uma mudança para $89 \%$. Como aspecto crítico do controle da enfermidade, identifica a garantia da adesão do doente ao tratamento a partir do aproveitamento do contexto da rotina do serviço, ou seja, na existência de um serviço de saúde estruturado, que utilize a prática do regime terapêutico intermitente, bem como a utilização dos recursos disponiveis na própria comunidade para assegurar a supervisão integral do tratamento.

A forma como se desenvolvem certas ações no âmbito dos serviços de saúde pode trazer conseqüências para a qualidade do atendimento, muitas vezes condenando o usuário a uma busca incessante de serviços, de forma aleatória e de muitas maneiras distintas, pois inexiste o vínculo entre a instituição de saúde e o doente. Dessa forma, o que se verifica é que também se encontra cerceada a universalidade, um outro pilar do Sistema Único de Saúde brasileiro, pois nem todos conseguem ser atendidos nos momentos necessários nos serviços que, teoricamente, deveriam estar disponíveis. Compromete-se ainda a eqüidade, uma vez que o atendimento dos serviços depende da sua permeabilidade ao problema que o usuário traz ou expressa (MERHY, 1996).

A frase temática seguinte: "a experiência positiva, em termos de organização do serviço de saúde, é veiculada (pelo próprio doente) para outro serviço de saúde" (4.38), significa que, na medida em que o serviço acolhe as necessidades do doente, este encarregar-se-á de divulgar os aspectos positivos da assistência, exercendo de fato o que se pode entender como controle social.

Por outro lado, cabe mencionar que: " a possivel/potencial falta de medicamentos na UBS provoca 'medo' no doente e determina a manutenção de um 'estoque' medicamentoso em sua casa" (7.29), atitude possivelmente fruto de experiências anteriores, reconhecidamente encontradas no sistema de saúde brasileiro. $\mathrm{O}$ conteúdo representacional dessa frase temátiva coloca em evidência, de certa forma, a debilidade desse sistema. que faz o doente precaver-se da ocorrência do fato, o que 
absolutamente não deixa de causar soluções de continuidade na própria organização do PCT, pois é inconcebível que todos os doentes tenham esse mesmo tipo de comportamento, o que estrangularia o desenvolvimento do programa.

Além das representações anteriormente descritas que mostram algumas limitações importantes no que se refere à forma de produção da saúde verificou-se que: "a unidade de saúde alberga parte da vivência do processo saúde-doença ('foi ali que tudo começou')" (2.48), o que evidencia que o serviço de saúde é tido como uma instância que efetivamente responderia às necessidades dos doentes, não as restringindo às de cunho biológico-assistencial, mas pelo contrário, considerando os problemas e as necessidades que trazem os doentes e reconhecendo-os sob a perspectiva que deles emerge e não a partir da ótica definida pela instituição.

Foi possivel ainda observar que "o encaminhamento do doente para o centro de referência (ICF $F^{6}$ ) ocorre devido a problemas relacionados à dosagem e à freqüencia da tomada de medicamentos" (3.22), fato que coloca em pauta a discussão sobre a necessidade da existência de uma unidade de referência que tenha como uma das funções o equacionamento da multirresistência às drogas, que deve constituir-se em um dos importantes problemas a serem enfrentados no futuro próximo, em função da própria debilidade do processo de adesão ao tratamento. Evidentemente que não se trata de criar unidades de especialização que reforcem ainda mais a dicotomia já existente nos serviços de saúde, que comprometa ainda mais a interpretação da saúde-doença como um processo articulado que envolve o ser humano em suas interrelações com a estrutura social. Por outro lado, há que resgatar o contexto em que se deu a situação referida pelo doente. Segundo ele, o encaminhamento ao ICF ocorreu pois o médico havia ministrado dose de medicamento superior às doses preconizadas, o que contribuiu para a ocorrência de efeitos colaterais. Ora. é bastante provável que outras falhas relacionadas à medicação possam estar tendo lugar, passando desapercebidas na assistência. A falta de supervisão e de avaliação do trabalho nos serviços de saúde, bem como a carência de informações atualizadas sobre as doenças e os esquemas terapêuticos, ações estas que fazem parte do Programa de Controle da Tuberculose, de modo geral, não vêm sendo efetivadas em

\footnotetext{
${ }^{6}$ ICF: Instituto Clemente Ferreira da Secretaria de Saúde do Estado de São Paulo
} 
consequiência do processo de deterioração instaurado no sistema nacional de saúde. Ressalta-se ainda que, no desenvolvimento da entrevista com o paciente em questão, tomou-se conhecimento que, em virtude dos efeitos colaterais produzidos pelos medicamentos, ele havia optado por fazer uso da medicação, em dias alternados. A dificuldade em se conhecer a raiz do problema não deixa com que sejam feitas inferências a respeito, mas põe em relevo a situação precária em que se coloca o PCT na atualidade.

As representações analisadas até o momento revelam os descaminhos da saúde na atualidade - ao evidenciar que o doente muitas vezes não expõe para o trabalhador de saúde a totalidade das informações sobre o seu processo saúde-doença, não conseguindo nem ao menos ter a sua representação sobre a enfermidade decodificada pelo profissional de saúde. Isso configura a inexistência da acessibilidade à saúde, bem como expõe a forma como estão organizados os serviços de saúde, os quais não disponibilizam tempo suficiente para escutar o que traz o doente em termos de necessidades, além disso coloca mais uma vez à tona a conhecida visão do trabalhador de saúde que ainda está calcada na perspectiva eminentemente biológica, em detrimento da compreensão social do processo saúde-doença. Dessa forma o que se verifica é que o atendimento às necessidades acaba realizando-se de forma setorizada, fragmentada, como se o individuo fosse um somatório de necessidades a serem satisfeitas. Essa forma de proceder destitui o sujeito da cidadania tornando-o apenas um usuário do serviço de saúde.

$\mathrm{Na}$ realidade, trata-se aqui de ampliar a análise do conteúdo das representações para a perspectiva do acesso a uma assistência que seja de fato de qualidade. O processo de deterioração que vem sofrendo o setor saúde tem imprimido um modo de produzir assistência à saúde que, falsamente colocado sob o signo de produtividade, tem permitido que a quantidade de pacientes atendidos seja um indicador na avaliação da qualidade dos serviços, em detrimento da relação estabelecida entre o profissional de saúde e o doente. Ademais. o que tem ocorrido é que. em virtude da forma como se concebe a produção em saúde, hegemonicamente, principalmente no âmbito municipal, os trabalhadores de saúde têm desenvolvido os seus processos de trabalho com base numa ideologia que não permite aproveitar o espaço da consulta médica, bem como outros, na unidade de saúde. para que aflorem questões que muitas vezes. senão na maioria. se referem ou determinam certos comportamentos e atitudes dos doentes em 
relação à sua saúde e que proporcionariam indícios sobre o seu posterior comportamento em relação à adesão ao tratamento. O que se tem assistido, particularmente nos últimos anos, é que o atendimento é baseado substantivamente na queixa que, em geral, é tomada pelo profissional de saúde como um sinal e ou sintoma que aparece desarticulado da base material de existência dos doentes.

Um outro ponto importante refere-se à articulação entre as ações desenvolvidas pelas unidades de saúde para responder às necessidades particulares dos sujeitos, e também às necessidades que emergem da coletividade e que de modo geral têm sido objeto de consideração somente se reconhecidas como de âmbito epidemiológico, ou seja, de grandes grupos e historicamente trabalhadas pela vigilância epidemiológica. A questão que aqui se coloca é que o reconhecimento dessas necessidades do coletivo só encontra lugar se as doenças são passiveis de disseminação entre as populações. Dessa forma, estabelecem-se medidas que visam sobretudo o seu controle momentâneo sem que seja buscada a raiz das questões. Evidentemente que essa é a forma por excelência pela qual a vigilância epidemiológica se estabeleceu, mas que cada vez mais urge por ser reorientada e que tem sido objeto de análise de certos investigadores, principalmente no âmbito da América Latina. Felizmente isso vem promovendo o desenvolvimento do campo de práticas e saberes da Saúde Coletiva projetada para transformar o entendimento da saúde-doença na coletividade. com vistas a redirecionar os projetos de intervenção para responder à transformação dos perfis epidemiológicos.

Não se trata aqui de defender uma visão "romântica" das práticas de saúde, mas de advogar que o mundo dos interesses do campo da saúde é “(...) inseparável do processo de construção das subjetividades, como territórios existenciais, para os quais se constituem os sentidos e os significados da própria luta em defesa da vida, e também do próprio conteúdo ético-prático desta noção” (MERHY, 1995).

$\mathrm{O}$ autor anteriormente referido afirma que, em função disso, inúmeros têm sido os exemplos que mostram "a desumanização dos serviços em relação à clientela; a falta de compromisso dos trabalhadores de saúde com o sofrimento dos usuários; a baixa capacidade resolutiva das ações de saúde: a intensa desigualdade no atendimento da clientela entre os diferentes estratos sociais (afirmando a existência de tipos diferenciados 
de cidadanias); o privilegiamento dos cidadãos, que podem pagar altos preços pelos serviços no acesso ao melhor que se tem no setor" (MERHY, 1996).

Na verdade, conforme aponta LEOPARDI (1992), tomando como base a argumentação de Heller, o atendimento às necessidades de saúde tem se traduzido na anulação da carência. $O$ sujeito, para satisfazer a sua necessidade, uma vez que não pode alcançá-la nos objetos e instituições conforme imagina - e teria seu verdadeiro direito -, acaba por se submeter ao que a sociedade the oferece, limitado pela disponibilidade do consumo que lhe é permitida.

Dependendo da forma como se processa a relação profissional de saúde-doente, o seu resultado faz com que o doente depreenda que a ação do primeiro não se restringe ao diagnóstico e à terapêutica, mas se refere ao seu próprio cotidiano profissional, o que evidencia uma certa ampliação da mera relação técnica que usualmente é reproduzida no contexto dos serviços de saúde: "o profissional médico compartilha com a doente o sentimento de perda por ter que deixar a unidade de saúde" (8.21) e "o profissional médico remete ao posicionamento político do doente a possibilidade de seu retorno ao trabalho na unidade de saúde" (8.22). Tais frases temáticas evidenciam não uma dependência do profissional médico em relação à ação do doente, mas uma confiança no seu papel como sujeito social. É bem verdade que essas últimas frases temáticas carregam um conteúdo de importância, na medida em que revelam uma modalidade de relacionamento entre o profissional e o doente que transcende a tradicional relação de hegemonia do primeiro. Aqui verifica-se a explicitação da fragilidade da inserção atual do médico no mercado de trabalho e a esperança de que o doente, como cidadão, possa constituir-se como um dos atores para a reversão desse cenário. No sentido de aclarar o conteúdo representacional da frase temática, veja-se a forma como originalmente o sujeito expôs seu depoimento:

“...Ela até me falou assim (referindo-se à profissional médica que a havia atendido): Que pena... eи vou embora daqui... (que ela também era daí, né?). Ela disse: Que pena, você, a nossa cliente, vai embora e eu também vou embora... Aí ela ainda falou assim prá mim... Quando você for votar, você vota na $x$ (referindo-se a ex-prefeito da 
cidade de São Paulo), viu? Porque se todo mundo votar nela eu volto aqui pro posto de novo... E eu falei: Tá bom... se você voltar é uma boa..."

Para MERHY (1996), o encontro entre um usuário, portador de uma determinada necessidade de saúde, e um trabalhador de saúde, possuidor de um dado "arsenal de saberes específicos e práticas", determina um momento do desenvolvimento da assistência, que comporta necessidades distintas: "um, ao carregar a representação de um dado problema como problema de saúde/necessidade de saúde, procura, no mínimo (...) uma relação de compromisso que tem como base, em geral, a sinceridade, a responsabilidade e a confiança na intervenção como uma possivel solução; o outro também está procurando nesta relação algumas coisas, mas esta procura não necessariamente tem algo a ver com o que o outro espera". O que se pode depreender do conteúdo representacional da frase apresentada é que pode existir também uma relação de confiança mútua entre o profissional e o usuário, através da qual o primeiro deixa clara inclusive a sua impotência para mudar a realidade, depositando no cliente a possibilidade de câmbio da situação.

É ainda MERHY (1996) quem procede a uma análise particular que ajuda a entender a forma como esse tipo de relação processa-se. $O$ autor afirma que os produtores de saúde, neste caso os profissionais de saúde, que são também instituintes de necessidades, atuam como força em conjunto com os consumidores de saúde, neste caso, o doente, no espaço onde ocorre a intercessão da produção e consumo de saúde. Nesse espaço são colocadas distintamente as intencionalidades, os desejos (conforme ressalta o autor, este último se constitui como um momento de expressão de vontades mais ou menos conscientes) e também as necessidades. E é nesse locus que se estabelece o "confronto", nem sempre conflituoso, de distintos formatos de necessidades (como carências ou como potências) e de suas possibilidades de satisfação. É ainda nesse espaço que pode ser concretizada a capacidade transformadora dos sujeitos, tanto do trabalhador de saúde, como do doente.

O que se verificou através do conteúdo representacional das frases anteriormente mencionadas é a evidência de que realmente nesse espaço nem sempre ocorre o conflito. Pelo contrário, neste caso a relação estabelecida entre o profissional de saúde e o doente 
revela uma necessidade explícita do profissional de saúde, que conta com a ação do doente para tornar possível a mudança de sua situação de trabalho. É interessante apontar que frente à tendência de proletarização da profissão, o médico, que sempre se destacou como potencializador da assimetria nessa relação instituída de poder, cada vez mais se torne um interlocutor para as necessidades de saúde-doença que são colocadas pelo doente, assumindo a posição de co-locutor para as carências que estão intimamente ligadas ao processo saúde-doença, as quais esse profissional e a medicina tem historicamente se negado a valorizar e intervir. Evidentemente que não se trata de defender o nivelamento desse profissional às classes subalternas, mas entender que o processo de proletarização a que vem sendo submetidos os profissionais médicos pode vir a criar um trabalhador que se veja obrigado a entender e intervir sobre os carecimentos sociais, defendendo uma nova modalidade de assistência em saúde, uma vez que também os experiencia. E essa não é uma questão peculiar ao profissional médico, pois o processo de implementação do neoliberalismo, com todas as suas consequências para os setores social e de saúde, particularmente para os assalariados e para os excluídos da sociedade, pode vir a gestar um novo modo de prestação de serviços de saúde que, paradoxalmente, seja mais aderente às necessidades dos doentes. Talvez seja essa a cruel realidade que se coloca para mudar a saúde no país. Talvez seja esse o desencadeamento para um novo olhar e fazer saúde que seja sobretudo mais ético, mais justo e que carreie uma dinâmica na qual os doentes não têm que se habituar a serem os subalternos na relação que envolve o seu corpo.

Por outro lado, um ponto que merece ser lembrado nesta análise é o fato de que essa é também uma questão de consciência de pertencimento ao grupo social, ou seja, o entendimento das necessidades do doente pelo trabalhador de saúde está permeada pela apreensão da forma como este último trabalha e vive, bem como pelas relações que se estabelecem no grupo ao qual pertence.

Ora, conforme pôde ser verificado através do conteúdo representacional das frases temáticas, a assistência à saúde se configura para os doentes, de modo geral, como impessoal, centralizada na figura do médico, evidenciando-se a ausência do profissional de enfermagem. Existe uma série de barreiras a serem transpostas pelo doente para a busca da assistência, as quais referem-se à forma como a pessoa se percebe em relação 
ao processo saúde-doença, aliada às possibilidades de acesso efetivo à saúde, bem como está intrinsecamente ligada ao atendimento às necessidades de saúde. De fato, a busca da assistência pelo doente depende da mobilidade que o sujeito tem no processo de produção social. Nesse sentido, evidenciou-se que em geral a procura do atendimento é realizada a partir do momento em que outros sujeitos sociais indicam para o doente a presença de alguma "anormalidade". Além disso, esta é deflagrada na presença de uma situação-limite, que se materializa através da presença de certos sinais, como a hemoptise e/ou pela incapacidade para o desenvolvimento das atividades do cotidiano. Observa-se que a assistência à saúde, particularmente aquela que se refere à tuberculose e que se constituiu em alvo do presente estudo, não tem permitido com que o doente de fato possa expor suas necessidades, sendo que a histórica desvalorização do saber do doente ainda configura-se como uma realidade na produção dos serviços de saúde, alicerçando a relação assimétrica entre o trabalhador de saúde e o doente. Verificou-se também que o doente retém uma imagem do processo de trabalho do profissional de saúde (do médico) que está configurada com base na cadeia de transmissão da doença, bem como pelo ato de prescrever o medicamento e proceder a encaminhamentos. Uma outra faceta do trabalho médico ainda revelou que a relação que é estabelecida com o doente pode constituir-se como ponto crítico para a adesão ao tratamento. Verificou-se também que as necessidades apresentadas pelo doente parecem ser refuncionalizadas pela instituição de saúde, a qual as modifica deixando de atendê-las ou atendendo-as parcialmente, segundo a ótica do trabalhador de saúde. Outro aspecto importante refere-se ao fato de que a quebra do sistema de saúde vem produzindo efeitos de várias ordens sobre o acesso dos doentes aos serviços. Evidentemente que são necessários outros tipos de investigações que aprofundem essa questão, relacionando os achados com a tuberculose e mais especificamente com a adesão ao tratamento. Na verdade, parece persistir uma forma tangencial de lidar com as questões que se referem ao cotidiano, que não responde substantivamente aos reais carecimentos de saúde apresentados pelos doentes. Estes configuram necessidades sociais na medida em que são verdadeiras, autênticas e conscientes necessidades dos homens, as quais são desenvolvidas historicamente. As necessidades configuram-se, portanto, como um produto que é constituido por determinados homens, pertencentes a determinadas classes sociais, em determinada época (HELLER, 1986). 
Face à caracterização da assistência anteriormente apresentada, que via de regra configura-se como fragmentada e de não acolhimento às necessidades do doente, na qual se evidenciam relações de poder, de certa forma hostis à consecução da adesão ao tratamento, a persistência do cliente é digna de nota. Esses doentes ultrapassaram as dificuldades inerentes a esse processo, enfrentando meses de retornos às consultas médicas, muitos deles sofrendo as repercussões da assimetria de poder institucional. Felizmente encontraram-se também representações que evidenciam redutos de resistência, tanto dos clientes, como dos trabalhadores de saúde, visando modificar as práticas de saúde. Alguns desses trabalhadores parecem manter o compromisso de transformação da situação de saúde no país, através do trabalho que desenvolvem no micro-espaço da unidade básica de saúde, por meio de ações que constituem um intento de manter o compromisso, a responsabilidade e o respeito com as pessoas doentes.

Por fim, é necessário salientar que, lamentavelmente, a lógica dos serviços de saúde apreende o consumo de serviços como um fim em si mesmo e não como um meio para o alcance de um padrão de qualidade de vida do ser humano (GALLO, 1995). Esse "estado de coisas" obstaculiza o caráter político das práticas de intervenção em Saúde Coletiva, no sentido de construir propostas de intervenção concretas e que redundem em melhoria na qualidade de vida e de saúde da coletividade. Essa deveria ser a tônica da reorientação dos sistemas de saúde no âmbito mundial, ao lado da eficiência e da eqüidade, do controle dos gastos e do aumento da capacidade de eleição e influência dos usuários nas demandas por assistência à saúde (ORGANIZACIÓN DE COOPERACIÓN Y DESARROLLO ECONÓMICOS, 1994), acoplada à ações de promoção da saúde (MINISTÉRIO DA SAÚDE, 1996a).

\subsubsection{Representações sobre o Tratamento}

As representações em relação ao tratamento evidenciaram grande variedade de concepções que variaram desde aquelas relacionadas às concepções sobre o tratamento específico contra a tuberculose, ministrado no âmbito da unidade de saúde, como aquelas relacionadas à incorporação de outros tipos de procedimentos e tratamentos, aquelas que se referem aos efeitos que os medicamentos causavam e, especificamente, as 
representações que se referem à adesão ao tratamento e que se constituem em objeto central da presente investigação.

Antes de verificar quais as representações que os doentes têm sobre o tratamento da tuberculose, vale apontar que este se coloca sob duas perspectivas, conforme aponta ROUILLON (1972), destacada pesquisadora sobre o tema, sendo que uma delas referese ao plano individual de intervenção, no que toca à possibilidade de alívio do sofrimento do doente, ao mesmo tempo em que coletivamente promove a proteção da sociedade ao romper com a cadeia de transmissão da doença.

Visto por esse ângulo, o tratamento certamente tem efeitos positivos para o indivíduo e para a coletividade. Mas, na realidade, que processos ocorrem quando o doente se vê diante da árdua tarefa de tomar a medicação durante um período de tempo tão longo? Elementos para responder a essa indagação podem ser obtidos do conjunto de representações que serão posteriormente descritas. Antes disso, vale dedicar poucas linhas a algumas reflexões que devem ser levadas em conta, na medida em que a adesão ao tratamento não envolve somente uma situação linear, na qual cabe unicamente à pessoa decidir sobre a ingestão da medicação ou não. Outros processos estão envolvidos, na medida em que o tratamento se configura como um elemento do processo saúde-doença. Tomando-se este como um processo inerente ao ser humano no contexto social há que verificar-se que o medicamento passa a ter um significado para o doente que transcende o biológico (CRAWFORD, 1980; LEFÉVRE, 1991; BARREIRA, 1992)

Veja-se a seguir, portanto, a forma como as pessoas concebem o tratamento medicamentoso.

Para uma parte dos sujeitos entrevistados prevalecem as representações que exprimem idéias de confiança quanto ao tratamento, na medida em que "o tratamento medicamentoso determina a melhora da doença/tb" $(2.17,7.9,10.13,16.5)$ e "faz viver" (16.5). Assim, a possibilidade de cura da doença através do tratamento suscita sentimentos de "tranqüilidade" e "sossego" (10.12), enquanto que "a dúvida sobre o sucesso do tratamento provoca 'preocupação'..." (12.19). Também a possibilidade de não ocorrer a cura da doença provoca "medo", em decorrência da "fragilidade fisica 
pregressa do doente" (15.6), ou seja, a debilidade do organismo é vista como uma limitação potencial à ação do medicamento. Mas, para outros, o seguimento do tratamento é qualificado como "terrivel" (4.15) ou "horrivel" (15.11), fundamentalmente em virtude dos efeitos colaterais ou do desconforto causado pela quantidade de medicamentos.

Verificou-se ainda que "o doente apresenta conhecimento sobre a necessidade do tratamento correto e completo para chegar à cura" (5.38) e, "o conhecimento/informação sobre a doença/tb estimulam o seguimento do tratamento" (14.21). Conforme pode-se verificar, uma vez que o doente percebe a importância do tratamento no curso da doença, passa a apresentar atitudes que traduzem a consciência e a voluntariedade sobre o processo. Evidentemente que a ação do sujeito em relação ao medicamento depende do conhecimento sobre o processo saúde-doença, daí a necessidade de que o serviço de saúde esteja aberto a promover informações tanto sobre o curso da doença como no que se refere ao desenvolvimento do tratamento. Sob o argumento de que o doente não consegue apreender o que se passa com ele no desenvolvimento do seu processo saúde-enfermidade, os serviços de saúde sistematicamente não aproveitam o espaço da assistência para compartilhar com as pessoas, informações que são fundamentais para o entendimento da forma de progressão da doença, além de elementos que permitam compreender o processo de transmissão.

Ao contrário do que se poderia supor, o grau educacional não apresenta relação com os índices de adesão (VAN DER WERF e DADE, 1990; RAMACHANDRAN e PRABHAKAR (1992). Entretanto, é fundamental ter em mente que estudos que procedem a análises estatísticas sem a apreensão objetiva do contexto onde vivem e trabalham as pessoas, bem como aqueles que realizam a leitura dos resultados sem a sua devida conexão com os processos que se dão no mundo da produção e reprodução social podem chegar a conclusões que equivocadamente acabam por reduzir as questões a relações lineares, unívocas, de causa e efeito.

A importância do conhecimento sobre a doença em relação à adesão ao tratamento é descrita por BARNHOORN e ADRIAANSE (1992) que estudaram doentes que apresentavam tuberculose na Índia. Os autores relatam que $79 \%$ daqueles 
que aderiram ao tratamento conheciam a doença e a extensão do tratamento, enquanto que essa porcentagem baixou para $46 \%$ no grupo de não aderentes. Além disso, verificaram que aqueles que aderiram apresentavam maior número de queixas em relação à ocorrência de febre, perda de peso e apetite, bem como sabiam a respeito da gravidade da doença e da importância da alimentação adequada e da periodicidade às consultas médicas.

MENZIES et al. (1993) ao estudarem uma série de 352 pacientes em um hospital de Montreal, Canadá, entre 1987 e 1988, verificaram que a adesão aumentava a partir do entendimento do paciente sobre a importância do uso do medicamento, além do acompanhamento contínuo do mesmo pela unidade de saúde, assim como do emprego de esquemas terapêuticos curtos como o de seis meses.

Por outro lado, verificou-se que a necessidade de tomar a medicação coloca-se algumas vezes como inevitável para o doente, evidenciando a sua submissão a uma situação que somente a terapêutica é capaz de mudar: "o tratamento é assumido pelo doente resignadamente, como uma necessidade imperiosa, sem alternativa" (18.12).

Ao mesmo tempo em que explicita a esperança que deposita sobre a atuação do medicamento sobre o processo saúde-doença, mantém a idéia de que "a tuberculose não é passivel de cura" (7.5), o que evidencia que, apesar do Programa de Controle ter sido implementado há algumas décadas, a população ainda têm dúvidas sobre a efetividade do tratamento. Ora, conforme explicitado na Introdução deste presente estudo, há evidências de que o tratamento adequado apresenta cerca de $100 \%$ de eficácia. Assim, o sucesso da quimioterapia depende não somente da indubitável potência das drogas, mas está ainda associado à sua prescrição adequada, à regularidade no uso, ao seguimento do tratamento no período necessário, à baixa toxicidade das drogas, além do crescente problema relacionado à resistência às drogas (FOX, 1972).

Sobre a questão específica da efetividade das drogas cabe tecer algumas considerações, antes de prosseguir na análise dos conteúdos representacionais das frases temáticas. Ainda que os medicamentos utilizados apresentem altos niveis de efetividade, não há dúvida de que a necessidade de cumprir um longo regime terapêutico é uma 
tarefa dificil de ser levada adiante. A diminuição do tempo de tratamento e da quantidade de drogas a serem ingeridas, facilitariam sobremaneira o seu desenvolvimento com diminuição da taxa de abandono.

O Programa de Controle da Tuberculose no Brasil recomenda o uso de algumas drogas de primeira linha, dentre as quais a rifampicina, a isoniazida e a pirazinamida, utilizadas de forma combinada nas duas fases do tratamento. A isoniazida é uma droga bastante efetiva, cuja eficácia primária é dirigida contra o crescimento do bacilo. A rifampicina é uma droga bactericida que atua na fase de crescimento dos bacilos. A sua absorção é quase que completa quando a pessoa se encontra em jejum. A pirazinamida apresenta maior atividade esterilizante sendo mais efetiva no interior do macrófago (BRAUSCH e BASS, 1993).

As três drogas são rapidamente absorvidas, atravessando rapidamente as barreiras biológicas, incluindo a hematoencefálica, sendo que suas concentrações no interior das lesões aproximam-se daquelas obtidas na corrente sanguínea (FOX e MITCHISON, 1975).

$\mathrm{O}$ exposto anteriormente conforma algumas bases que têm fundamentado o emprego dessas drogas no Programa de Controle da Tuberculose no Brasil. Essas drogas começaram a ser utilizadas nas últimas décadas, sendo que a pirazinamida foi a mais recente a ser adotada, e proporcionaram a substituição dos regimes anteriormente utilizados, bem como a internação e a toracoplastia, entre outras práticas, que devido às suas conseqüências para os doentes, tanto no plano biológico, como no emocional e no social, passaram a impregnar o imaginário popular de medo em relação à doença. A coletividade parece acompanhar, de certa forma, as mudanças dessas práticas, pois verificou-se no presente estudo a seguinte representação sobre o tratamento: "houve modificação do tratamento para a tuberculose, da época antiga à atualidade", tratamento esse que modificou o resultado da evolução da doença, pois anteriormente ela "causava a morte" (5.34). Evidencia-se, portanto, que a submissão do paciente ao tratamento tem como base a tentativa de evitar um desfecho fatal. Assim. o temor por esse resultado ajudaria a cumprir o tratamento na sua totalidade. Dessa forma, o projeto do indivíduo está articulado a um bem maior que é a vida. É LEFÉVRE (1991) que ao 
analisar o medicamento como uma mercadoria simbólica, coloca que ele representa a vida “... na medida em que esta vida (...) é a eliminação da morte como concretude”.

A confiança em relação ao tratamento é evidenciada em alguns depoimentos: “ $a$ melhora da sintomatologia é observada logo no primeiro dia de ingestão (9.14), terceiro dia (14.35), uma semana (15.10), a partir de 15 dias do inicio do tratamento medicamentoso (6.10), em um mês (17.32), a partir do segundo bimestre (11.14) e após o primeiro trimestre $(3.11 ; 8.10)$. Verifica-se assim, que para alguns, o ato de tomar a medicação, já na primeira semana de tratamento é tido como um fato que determina a melhora da sintomatologia, evidenciando o crédito na ação medicamentosa.

Para algumas pessoas, o efeito da ação das drogas no organismo é evidenciado por certos resultados, como: "ganho de peso" $(6.3,9.14,11.15,11.24,13.19,14.35$, 17.21, 18.22), "aumenta o apetite do doente" (1.15), "aumento da disposição" (11.15, 13.19, 17.21), " melhora da falta de ar e da diminuição da dor" (11.15), " ausência de dor nas costas e nas pernas" (18.9), "melhora da tosse, vômitos e a fraqueza" (3.11), "do ‘ânimo”" (13.19), “da conciliação do sono” (14.35) e "conseqüente reaproximação das pessoas" (17.21). Verificou-se ainda que o tratamento determina "mudança na vida" (9.14).

Assim é que as conseqüências da tuberculose, tais como o emagrecimento, o definhamento, a falta de capacidade para o desempenho das atividades do cotidiano, a presença de dor e as conseqüências do afastamento do convívio com outros, são alterados pelo uso da terapêutica, daí que esta assuma para o doente uma importância fundamental. Tanto o é que se verificou que "o tratamento limita-se ao uso contínuo da medicação (8.14), sendo que "o tratamento correto é constituido por horário correto (12.10, 17.25) e jejum, quando necessário" (12.10). Segundo LEFÉVRE (1991) o medicamento como um símbolo, aparece como algo cujo sentido é “... o de resolver (destaque do autor) um estado mau (destaque do autor) - de necessidade -, conduzindo a um estado bom (destaque do autor) - satisfação-".

É importante destacar que algumas vezes o medicamento assume um papel que na escala de valores do doente é secundário ao espiritual. Assim. verificou-se que " $a$ 
possibilidade de melhora/cura é delegada ao destino (12.31), à entidade divina (14.39, 8.17), que 'ajuda', 'dá força' em primeira instância, e à ingestão dos medicamentos" (8.17), o que evidencia uma vez mais que seguir o tratamento se deve a uma crença de que a superação da doença transcende à ingestão das drogas e que tem a ver com a conviç̧ão intima de caráter religioso, que sustenta o enfrentamento da doença. Imputando o crédito do sucesso do tratamento ao transcedental, o doente não deixa de fazer uso de práticas alternativas. Tanto é que "a 'falha' no cumprimento da obrigação 'religiosa', destinada à cura, provoca 'preocupação' no doente" (14.38). Verifica-se que o doente vale-se de várias estratégias para obter a melhora ou a cura da doença, desde a obediência às palavras do profissional médico, até o uso de práticas de senso comum, em geral extraídas da cultura popular de onde vive, que desempenham um papel igualmente importante.

De qualquer forma, parece haver uma conjugação de poderes quando se refere ao sucesso do tratamento, pois: "a responsabilidade pelo sucesso do tratamento, se devida à ação médica ou à ação divina, provoca sentimento de ambigüidade por parte do doente" (14.41). Aqui entra em cena a figura do trabalhador de saúde, o qual passa a integrar o imaginário do doente como aquele responsável pela debelação da doença. Tanto o âmbito do divino, como do profissional médico ocupam planos semelhantes, o que faz depreender que, possivelmente, para o doente, a ação deste último tem um equivalente à superioridade que impregna a concepção sobre o divino.

Ainda em relação às concepções sobre a cura, mas numa outra perspectiva, verificou-se que "a cura da doença/tb é imputada à ciência" (14.59), o que evidencia que o doente remete a questão a plano que, da mesma forma que em relação ao plano espiritual, o alija do processo de cura, posto que o restabelecimento da doença ocorreria sem a sua participação ativa. A dimensão da ciência põe em evidência uma interpretação a partir de um campo em que o doente dispõe de menor conhecimento e menor potencialidade para a ação, na medida em que não faz parte de seu cotidiano, diferentemente do âmbito espiritual, que de uma certa forma associa-se à sua vivência e para a qual ele tem maior acesso e ativamente busca respaldo. Por outro lado, ao remeter a cura para o plano da ciência. o doente se afasta ainda mais do processo de cura, 
tornando-se observador do seu desenvolvimento, já que o doente não teria instrumentos para compartilhar desse conhecimento com o médico.

O próprio processo terapêutico não é isento de dificuldades, mesmo em se tratando de pessoas que completaram o tratamento, verificando-se que este provoca: dor no estômago (2.19, 16.13), azia (17.22), "reação" (18.11), como "coceira" (6.9, 9.15), "alergia" (9.15), "nervosismo", secundário à coceira (9.15), "gases" (7.19), vômito (12.22), diminui a capacidade para locomoção (7.9), proporciona dificuldade para andar (3.10), o surgimento de hepatite medicamentosa (10.13), provoca fraqueza, desânimo (3.10, 8.10), mal estar fisico (3.10), sonolência, enjôo, vômito, dificuldade para comer $(3.10,4.15,8.10)$, além de alterações no organismo (do ciclo menstrual) (15.14), ou causa "cheiro de enxôfre na pele" (4.15). Também: "a reação indesejável ao tratamento medicamentoso se concretiza especificamente no estômago, figado e pele" (12.24), evidenciando que a representação desloca-se do sinal e sintoma, para o órgão que parece ser acometido. Parece também haver clareza de que esses efeitos manifestam-se quando "da ausência de ingesta alimentar (2.19), ou: "a diminuição dos efeitos das reações dos medicamentos é obtida através da 'boa alimentação'” (17.23).

Em algumas falas, a manifestação dos efeitos colaterais ocorre principalmente durante o "primeiro bimestre" $(4.24,17.22)$. Mas, mesmo na presença de efeitos colaterais, esses doentes deram continuidade ao tratamento $(3.13,4.16,6.9,9.17,7.19$, 16.13, 18.11). Vale mencionar que um doente referiu a necessidade de "interrupção parcial do tratamento, em virtude de vômito"(12.22). Fez-se presente o "desejo manifesto, porém não concretizado, de interromper o tratamento" (4.24), o que torna explícita a idéia de que a necessidade de tomar os medicamentos e as reações advindas de seu uso provocam sentimento de ambigüidade nos sujeitos.

Os esquemas de tratamento utilizados atualmente têm sido descritos como bem tolerados, no entanto, alguns doentes podem apresentar reações adversas com o uso dessas drogas. As mais freqüentes são o comprometimento hepático, as manifestações de irritação gástrica e as reações de hipersensibilidade. As reações adversas anteriormente descritas costumam ocorrer no início do tratamento (MINISTÉRIO DA SAÚDE, 1994b). Esses efeitos medicamentosos podem conduzir, devido à sua severidade ou 
desconforto, ao abandono do tratamento, o qual poderia ser reduzido através da difusão de informações para o doente, bem como pela possibilidade de proporcionar maior flexibilidade no horário das medicações para minorar os efeitos colaterais, adaptando os esquemas terapêuticos segundo a rotina diária das pessoas (JOHNSTON e WILDRICK, 1974; DEHEINZELIN et al., 1996; BUCHILLET, 1997).

A isoniazida, em geral, é uma droga bem tolerada, mas pode causar reações adversas como hepatite ${ }^{7}$, queixas gastrointestinais, neuropatia periférica, bem como efeitos no sistema nervoso central, caracterizados por adormecimento e formigamento de extremidades distais, principalmente dos pés. Esta última é mais comum em desnutridos, diabéticos, urêmicos e alcoolistas (JOHNSTON e WILDRICK, 1974; BRAUSCH e BASS, 1993; MILLER, 1993; MINISTÉRIO DA SAÚDE, 1994b). A elevação assintomática das transaminases hepáticas ocorre em 10 a $20 \%$ dos indivíduos, mas o uso continuado do medicamento em geral faz desaparecer essas anormalidades (BRAUSCH e BASS, 1993).

A pirazinamida produz baixa toxicidade, sendo que a queixa mais relatada pelos usuários é a artralgia, aparentemente menos comum nos regimes terapêuticos intermitentes ( FOX e MITCHISON, 1975; BRAUSCH e BASS, 1993; MINISTÉRIO DA SAÚDE, 1994b). DUBRA (1972), em um estudo realizado em Buenos Aires, Argentina, encontrou sobretudo a intolerância digestiva, caracterizada por náusea, vômito, dor epigástrica, além de hepatite.

A rifampicina parece apresentar menor toxicidade, sendo que os principais efeitos encontrados têm sido as reações cutâneas, como prurido, além de desconforto gastrointestinal e disfunções hepáticas, caracterizadas pela elevação dos níveis de transaminases. A incidência de hepatite é de 1 a $2 \%$, mas aumenta quando da associação da rifampicina com a isoniazida (JOHNSTON e WILDRICK, 1974; BRAUSCH e

\footnotetext{
${ }^{7}$ Segundo JOHNSTON; WILDRICK (1974) e BRAUSCH; BASS (1993) os efeitos da toxicidade no figado, pelo uso da isoniazida ocorrem mais significativamente em pessoas com maior idade. A hepatite clínica pode ser encontrada em aproximadamente 1 a $2 \%$ das pessoas que fazem uso do medicamento.
} 
BASS, 1993). Além disso, pode causar náusea, vômito, broncoespasmo, manifestações hemorrágicas e comprometimento do sistema nervoso central (MINISTÉRIO DA SAÚDE, 1994b).

Os doentes cujos depoimentos foram analisados constituíram um grupo de pessoas que, a despeito de terem enfrentado situações adversas no decorrer do uso da terapêutica, de alguma forma superaram esses obstáculos. O que os levou a seguir adiante, fazendo-os diferentes daqueles que abandonam o tratamento? É necessário seguir um pouco mais analisando as representações e o comportamento dessas pessoas em função do contexto onde viviam para tentar identificar pistas que levem ao entendimento desse processo. A importância do monitoramento desses possíveis obstáculos pelos trabalhadores de saúde, em primeiro lugar tem a finalidade de acolher a queixa em decorrência desses efeitos colaterais, bem como proporcionar elementos que ajudem o doente a ultrapassar esse processo, daí que a intervenção dos profissionais de saúde é fundamental. No presente estudo verificou-se que em algumas situações isso ocorreu, ainda que sob a forma de ações focais e restritas às queixas apresentadas pelos doentes. Verificou-se tanto que "existe orientação médica quanto aos efeitos colaterais dos medicamentos" (2.18), como também o contrário, que "as orientações sobre os efeitos colaterais dos medicamentos não são explicitadas integralmente pelo médico para não induzir o doente a senti-las (4.28).

O estudo a seguir relatado pode proporcionar alguns elementos interessantes para o aprofundamento da análise da situação anterior. GUPTA et al. (1992), em investigação realizada na Índia, dividiram 60 pacientes portadores de tuberculose pulmonar em dois grupos, sendo o primeiro informado a respeito da possível ocorrência de anorexia e/ou vômito em decorrência do uso de isoniazida, rifampicina e pirazinamida. Os autores verificaram que a evidência de toxicidade às drogas foi maior $(30 \%)$ no grupo que não foi informado do que no primeiro $(3,3 \%)$. A experiência profissional tem demonstrado que a disseminação de informações sobre a ocorrência de efeitos colaterais tem contribuído para que o doente compreenda que o desconforto é esperado, podendo ser controlado e superado, dependendo da complexidade com que se apresente, sendo que, via de regra, não há necessidade de mudança da medicação. É importante deixar claro que, evidentemente, não se trata de passar ao largo das queixas do doente, mas de em 
conjunto com ele pensar em alternativas que possam contribuir para a modificação dessa situação.

Verificou-se também que "as reações ao tratamento medicamentoso são atribuidas à superdosagem de medicamentos" (3.12). Ou ainda que "a rejeição medicamentosa é atribuida ao hábito de não tomar medicamentos e por acreditar que as doenças podem ser resolvidas no cotidiano, na forma de viver a vida" (4.29).

No entanto, para outros doentes "o tratamento medicamentoso é um processo rotineiro/normal, incorporado ao cotidiano" $(2.22,18.21)$, sendo que o seu "sucesso deve-se à incorporação do tratamento medicamentoso ao cotidiano, ainda que seja 'desagradável'” (7.25). E ainda, que "a adesão ao tratamento está articulada à rotina do cotidiano" (1.19) e "da consciêncialnoção sobre a necessidade do tratamento, e é definido por 'regras' ('não tomar a medicação com leite')" (17.34). Isto quer dizer que para alguns o tratamento não se constitui em um momento ímpar da vida, mas se dilui no cotidiano, consubstanciando-se em uma ação a mais no seu viver a vida. Conforme explica HELLER (1970) a vida cotidiana se conforma como uma certa sucessão linear de gestos, atos e atividades repetitivas no dia-a-dia e a rotina é característica da cotidianidade.

Mas, é ROIULLON (1972) que mais uma vez coloca em questão uma leitura bastante apropriada sobre o significado da adesão em função de um processo que absolutamente não é fácil de ser levado adiante, pois se constitui em um artificio para viver. Para ela, tomar o medicamento não se constitui em uma rotina do cotidiano, mas o ato deve ser transformado em rotina e, muitas vezes vulgarizado e banalizado enquanto tal, para garantir a adesão.

Para alguns, o processo de tratamento é incorporado a algum elemento que integra a sua rotina diária: "o tratamento medicamentoso é seguido em função do tempo (o relógio é a concretização da necessidade de ingerir o medicamento) " (18.10) ou: "o seguimento do tratamento medicamentoso é efetivado através de "estímulos" (colocar o medicamento em lugares estratégicos) que incorporam o medicamento ao cotidiano" (7.18). Uma vez que aqui estão sendo reproduzidas as representações de sujeitos que 
completaram o tratamento, parece que para estes há um processo de incorporação não só do tratamento medicamentoso, mas do fenômeno da doença no dia a dia, o que resultaria em algo a mais a ser reproduzido na sucessão da vida.

Por outro lado, revelou-se também que "o medicamento provoca ao mesmo tempo dependência para a cura e dificuldade de torná-lo parte da rotina diária" (9.27). Nota-se assim que coexistem tanto representações que evidenciam o esforço do doente em tornar o ato de tomar o medicamento como parte da vida, como outras que evidenciam a dificuldade em lidar com essa questão que é, entretanto, ultrapassada. Isso é corroborado pela existência de uma certa ambigüidade de sentimentos, pois "o tratamento medicamentoso é tido como 'normal' e 'difícil' (9.13), o que deixa clara a complexidade do processo que se apresenta como contraditório para o doente.

Outros elementos ajudam a compreender essa dinâmica para o doente, pois o tratamento apresenta-se: "horrível" no inicio, devido ao tamanho dos comprimidos e à necessidade de sua ingestão com leite" (15.11) ou então: "a quantidade de medicamentos a serem ingeridos é apontada como um fator negativo no tratamento (5.1, 9.21, 13.17) e provoca "pavor" (12.5). Além disso, o "incômodo de tomar a medicação efetiva-se devido ao horário" (2.23), o que coloca em pauta a mudança causada pelo medicamento na rotina diária do doente. É curiosa a forma como alguns apreendem esse processo: "a necessidade de ingesta diária $(12.25,13.17)$ dos medicamentos é apontada como fator negativo, pois faz lembrar o 'estar doente', mas ao mesmo tempo 'dá força' para fazer o tratamento" (12.25), o que revela a contraditoriedade entre a necessidade/o dever e a negação da enfermidade conjugados à motivação para a superação do processo. Também " $a$ ingestão dos medicamentos provoca 'constrangimento', quando há que tomá-los próximo a pessoas que desconhecem a doença/tb, mas isso não impede a continuidade do seguimento do tratamento (13.9).

Ao mesmo tempo em que evidenciaram-se essas representações que colocam em pauta os eventos que se relacionam ao projeto de adesão e que se constituem em obstáculos que acabam sendo transpostos nesse projeto, verificou-se que são destacados pelos doentes outros aspectos, dentre os quais que "o uso de comprimidos por via oral é 
apontado como positivo para o sucesso do tratamento" (7.28). Assim, parece ser claro que o sujeito que depende do medicamento e que adere ao tratamento acaba muitas vezes por minimizar os problemas que emanam desse processo a uma esfera que possibilita a sua vivência da forma menos agressiva possível.

O tratamento atua efetivamente como uma barreira a ser transposta pelo doente, configurando-se como algo exterior ao seu universo e que passa a ser incluído no seu dia a dia. $O$ fato dos doentes aderirem ao tratamento não significa que essas dificuldades não existam, mas significa que são lidadas de uma forma peculiar. Para alguns, ter que incorporar o medicamento ao cotidiano provoca uma tensão entre a concepção que têm o sujeito sobre a doença e o seu tratamento e a necessidade de submeter-se a um procedimento que não acreditam. Assim, "a necessidade de realizar o tratamento medicamentoso entra em choque com o hábito de não tomar medicamentos" (4.32, 7.8), bem como: "a prática religiosa é indicada como um fator desestimulante para o consumo de medicamentos no cotidiano" (4.31). Apesar dessas crenças contrárias à necessidade de dedicar-se ao tratamento, o indivíduo consegue ultrapassá-las e buscar atender ao projeto de adesão.

A duração do tratamento apresenta-se quase que como uma ameaça, pois: " $a$ possibilidade de ampliação do período de medicação diminui o sentimento de ambigüidade (sobre a necessidade/vontade de tomar a medicação) e determina a opção pelo seguimento do tratamento" (7.27). Ou seja, frente à possibilidade de ter que prolongar ainda mais a duração do tratamento, o doente acaba por submeter-se ao mesmo. Aqui mais uma vez é importante frisar que tratam-se de representações de pessoas que aderiram ao tratamento, o que denota todo um conjunto de comportamentos, idéias e concepções de sujeitos que superaram as dificuldades advindas desse processo. Não se trata, portanto de negar esses obstáculos na vida desses individuos, mas de perceber que a forma como buscam transpor esses processos é particular, e pode ser tomada como referência para entender os comportamentos dos indivíduos frente ao adoecimento e tratamento contra a tuberculose, uma vez que evidenciam as possibilidades de comportamentos que têm lugar com esses sujeitos. 
A questão relativa ao período de tratamento é apontada como um dos grandes estrangulamentos do Programa de Controle da Tuberculose (JOHNSTON e WILDRICK, 1974). FOX (1972), em estudo realizado na Índia, verificou que a média esperada de não adesão com 6 meses de tratamento foi de $19 \%$, enquanto que com 12 meses obteve-se $27 \%$ de abandono. Essa é uma questão que, aliada ao desaparecimento dos sintomas por ocasião do início do tratamento em decorrência da efetividade das drogas, tem sido observada, tanto na prática profissional, como na literatura, em que aparece como um dos elementos que contribuem para o abandono e que, portanto, deve ser alvo de monitoramento por parte dos trabalhadores de saúde no cotidiano da assistência (KENT et al., 1970; FOX, 1972; FOX e MITCHISON, 1975; DEHEINZELIN et al., 1996; BUCHILLET, 1997).

Em relação à melhora que o doente vivencia por ocasião do uso da medicação, verificou-se que esta "suscita um sentimento ambiguo sobre a necessidade/vontade de tomar a medicação" (7.26). BAYER e DUPUIS (1996) mencionam a complexidade dessa situação, uma vez que a maioria dos doentes com diagnóstico de tuberculose aderem ao tratamento no seu início, na tentativa de evitar o desconforto dos sinais e sintomas que a doença carreia, principalmente a fraqueza, a febre, a tosse e a transpiração noturna. Da mesma forma, FOX e MITCHISON (1975) já alertavam para o fato de que os pacientes livres de sintomas passam a apresentar solicitações e argumentos para "livrar-se" dessa situação. Num determinado momento, a doença em si coloca-se como um problema, mas à medida em que desaparecem os sinais e sintomas que a caracterizam, cessa a necessidade de dar continuidade ao uso dos medicamentos. Os autores anteriormente apontados enfatizam que essa situação pode ser contornada através da explicitação para o doente, de que sua "cooperação" é necessária. Por trás desse argumento, enfatizam que são necessárias informações adequadas por ocasião do inicio do tratamento e que estas devem ser repetidas sempre que os pacientes mostrem sinais de irregularidade na ingestão da medicação ou nos retornos às consultas médicas.

Fica evidente o fato de que não basta ter com o doente uma atitude na qual o papel do profissional de saúde se resume à aplicação de orientações prontas, padronizadas e homogêneas para todos, indiscriminadamente. Aos profissionais de saúde cabe contemplar as necessidades expostas pelos doentes, buscando acolhê-las como mais 
uma necessidade a ser equacionada no âmbito da assistência. $\mathrm{O}$ medicamento revela-se artificial na vida do doente, o que não pode ser negado no serviço de saúde, mas compreendido como um momento a ser transposto no processo saúde-enfermidade. Da mesma forma, proporcionar elementos para que os indivíduos compreendam como se desenvolve a doença, não somente a partir da manifestação declarada da sintomatologia, é tarefa que cabe aos trabalhadores de saúde, buscando com isso, também a desmistificação da enfermidade.

Diferentemente das repercussões da doença sobre a vida do doente, que levavam a modificações no cotidiano até o impedimento do desenvolvimento de certas atividades, verificou-se que "os efeitos causados pelos medicamentos não impedem a continuidade do trabalho" (8.11), pois o desconforto por eles causado apresenta menor magnitude que o desenvolvimento da doença propriamente dita.

A atitude do profissional de saúde e, especificamente no presente estudo, a do médico, que foi referido como o protagonista da assistência na maioria dos depoimentos, ajuda a influenciar o comportamento do doente na adesão ao tratamento: "o seguimento do tratamento pelo doente ocorre devido à noção de seriedade com que o profissional médico imputa à doença” (12.9). Nesse caso, o papel do profissional assume um significado relevante que outorga somente a ele a possibilidade de: " a interrupção do tratamento... é conduta que só pode ser tomada pelo profissional médico" (11.25). Essa postura do doente revela o significado que tem para ele esse profissional, bem como evidencia o poder que este detém sobre o sujeito. Segundo LEFÉVRE (1991), no momento em que a cura é assegurada pelo medicamento, reproduz-se o poder médico sobre o doente, na medida em que o médico é o “... dispensador do medicamento". Para o mesmo autor, parece tratar-se, portanto, de uma relação assimétrica na qual ainda que o poder intituído esteja mascarado, determina ao doente a necessidade de valer-se do medicamento para a cura da doença.

Para outros "o seguimento do tratamento não é um processo 'difícil' devido à crença divina" (8.18), o que coloca mais uma vez em relevo o fato de que o doente vale-se de um conjunto de medidas ou de crenças que ajudam a apoiar o desenvolvimento do tratamento, as quais ora se consubstanciam fundamentalmente na 
figura do profissional de saúde, ora são deslocadas para crenças de ordem espiritual. Assim é que para alguns "o sucesso do tratamento depende, em primeiro lugar, da interferência divina e, depois, da assistência médica" (8.19).

Conforme pôde ser verificado, o tratamento é tanto assumido por alguns como uma etapa para a consecução da cura, como por outro lado é tomado resignadamente na falta de outras alternativas que o levem à retomada de sua capacidade produtiva. A crença no poder do medicamento para transformar a situação de vida do doente concretiza-se na forma como percebe a sua recuperação, principalmente biológica. É fato também que o tratamento é conjugado a outras medidas além do uso do medicamento, que se relacionam à forma como o doente concebe a saúde-doença. Nesse sentido, assume relevo o crédito no poder divino para a obtenção da cura.

As dificuldades que emanam dos efeitos colaterais dos medicamentos determinam sentimentos de ambigüidade em relação à necessidade da continuidade de seu uso, mas não impedem o seu seguimento, uma vez que parecem estar associadas a alguns elementos que promovem a manutenção desse comportamento, conforme será verificado quando forem apresentadas as representações a respeito da adesão ao tratamento. Ainda é importante mencionar que o papel do profissional médico no desenvolvimento do tratamento revela-se como crucial. Veja-se, portanto, a seguir como se configuram as representações dos doentes especificamente quanto à adesão ao tratamento.

\subsubsection{Representações sobre a Adesão ao Tratamento}

As representações a respeito da adesão dos pacientes ao tratamento contra a tuberculose foram agrupadas, devido à diversidade de concepções subtraídas das entrevistas realizadas. Conforme pode ser verificado a seguir, esses grupos de representações referem-se: ao papel imputado aos diferentes atores (familiares, profissionais ou outros) no desenvolvimento do tratamento, a forma como a adesão revela-se como uma questão articulada a outros processos que integram a vida da pessoa, a sua subsunção a um projeto maior que envolve o cotidiano, assim como a sua 
dependência a alguns elementos da vida do paciente, aqui denominados "facilitadores" do processo de adesão ao tratamento.

Antes de dar início é fundamental ter em mente que a adesão ao tratamento envolve uma série de aspectos complexos que devem ser trazidos à tona para definir com clareza a que conceito está se fazendo referência, conforme indicado na Introdução do presente estudo. GORDIS (1989) chama a atenção para a necessidade de se proceder à distinção, em primeiro lugar, dos fatores ou das situações que levam à adesão e à não adesão. Alerta para o fato de que, apesar dos pacientes manifestarem a intencionalidade da adesão, podem se deparar com a complexidade da terapêutica e interromper o tratamento. Além disso, admite que outras questões, entre elas as relacionadas ao potencial intelectual do paciente, podem obstaculizar o processo. Entretanto, conforme BUCHILLET (1997), não se trata apenas de analisar a não observância do tratamento em função da "má vontade, da irresponsabilidade, da ausência de motivação ou ignorância do paciente...", como crêem muitos. A autora defende que a adesão é um produto de uma complexa interação entre fatores de diversas ordens que geralmente se encontram fora do controle do paciente, cabendo ao serviço de saúde proceder a essa identificação, com a finalidade de buscar diminuir as taxas de abandono do tratamento. Também não se trata aqui de tomar a não adesão como um comportamento ou uma atitude consideradas de risco, submetidas a um olhar medicalizado e de apenas interceder sobre o problema através de estratégias que revertam ou corrijam os comportamentos e atitudes. pois dessa forma, estar-se-á condenando a doença como uma falência moral individual.

Assim sendo, não se trata apenas de arrolar fatores que levariam ou não à adesão, mas de proceder a uma análise que leve em conta que essa é uma questão dentre as tantas que se colocam à tona quando se trata de investigar processos que se referem ao processo saúde-doença. Embora as questões que se referem à adesão sejam aqui apresentadas de forma progressiva, de forma alguma essa estratégia deve ser compreendida apenas como uma somatória de fatores que nele interferem. Antes, tratase assim de desconstruir essa totalidade maior, que é o processo de adoecer, decompondo-o e explicitando quais são os sub-processos que potencializam a adesão ou 
aqueles que contribuem para o estabelecimento de rupturas que levam finalmente à não adesão para proceder a uma síntese que contemple a totalidade do processo.

Em primeiro lugar é necessário ter em mente que a adesão ao tratamento parece estar relacionada à forma como a pessoa concebe a doença, bem como do significado desta em relação ao cotidiano, sendo fundamental que isso seja interpretado no âmbito dos serviços de saúde. Nestes, a adesão, assim como o óbito, a alta, devem expressar não somente uma tipologia que classifique os indivíduos para fins operacionais, mas esses "resultados" são produtos que retratam a relação entre o trabalhador de saúde e o doente, articulada a três planos: o da organização da sociedade, com o estabelecimento de determinadas políticas de saúde; a sua conformação em grupos sociais distintos e o dos processos peculiares de manifestação da saúde-doença de cada um dos sujeitos sociais. Assim, a adesão, por um lado, evidencia aspectos inerentes ao sujeito social em relação com a sociedade, mas também retrata a face relativa ao serviço, uma vez que traduz também a apreensão e resposta institucionais às necessidades dos doentes.

Um último ponto que deve ser aqui explicitado refere-se ao fato de que a presente investigação tem como objeto a forma como os doentes entendem a adesão ao tratamento, objeto esse que não tem sido alvo de estudos. Interessa identificar as representações dos sujeitos a respeito do processo de tratamento que determina que eles o levem a cabo. A análise dos depoimentos para a extração das frases temáticas mostrou que a adesão dos doentes ao tratamento está intrinsecamente articulada à presença de outros sujeitos. Desta forma, inicialmente, a descrição e a análise dessa questão terão como foco o papel que têm outras pessoas no processo de adesão ao tratamento.

$\mathrm{O}$ apoio que os familiares (mãe: 1.18, 2.34, 3.20, 3.23, 4.21, 8.15, 9.19, 10.15, $11.19,12.27,17.33$; e outros: $13.7,15.1216 .24,16.11)$, os amigos $(2.35,17.29)$, os vizinhos $(2.35,3.23 ; 16.11)$, padre $(2.35)$ e outros, incluindo o empregador $(1.18,5.46)$, ou os profissionais de saúde, como o médico $(4.17,5.42,12.27,13.7)$, os integrantes da equipe de enfermagem (12.27) e a assistente social (13.7) oferecem ao doente é um dos pontos considerados fundamentais para a adesão ao tratamento. 
Verifica-se que esse amparo materializa-se sob diferentes perspectivas, desde a participação no desenvolvimento da doença e dos sentimentos que dela advém, até no desempenho de ações relacionadas ao cotidiano, como: "do afeto familiar" (14.55), "preparo de alimentos" $(2.26,3.20,6.8,17.33)$, "conversa" $(1.18,3.20)$, "proximidade, visita, apoio financeiro, incentivo para ir às consultas médicas" $(2.34,3.23,4.21,9.19$, $11.15,13.14,15.12)$, "levar ao médico/hospital" (12.27, 16.11), "trazer o remédio" (3.20), "obtenção de vaga no serviço de saúde" (6.8), "cuidado prestado" (7.21), "presença e pelo preparo de chás" (3.23), "enfrentar a situação de debilidade crescente em função da doença/tb" (14.16), ou mesmo manifestando suas opiniões a respeito da evolução da doença, como: "da observação 'positiva'... sobre a aparência do doente" (2.35), assim como recomendando ao doente a limitação do "excesso fisico"(2.35).

Reforçando o conteúdo das frases temáticas anteriormente descritas, fica bastante evidente que, para o doente. "o seguimento do tratamento deve-se ao incentivo..." (11.21). A participação de outros sujeitos no processo de tratamento pode ser vista como um elemento facilitador da incorporação da doença ao cotidiano, de forma que o doente de certa forma aprenda a conviver com a mesma, tornando-a como uma etapa da vida que deve ser assimilada e compreendida.

A presença de pessoas que possam compartilhar com o doente, tanto o enfrentamento da enfermidade, como as dificuldades inerentes ao tratamento medicamentoso é de suma importância pois: "o desejo manifesto de interromper o tratamento medicamentoso não é concretizado totalmente ('dia sim/dia não') devido ao estímulo paterno em primeiro lugar e, secundariamente devido à mãe e vizinha" (3.17). Ou: "o fato das pessoas da familia (de modo geral) não auxiliarem no tratamento é considerado como dificuldade no seu desenvolvimento" (3.24).

Por outro lado, vale apontar o conteúdo representacional da seguinte frase temática: " $a$ incorporação das orientações e do estímulo (preparar alimentos, promover transporte, alimentação nutritiva) para o seguimento do tratamento, dependem de cada pessoa" (17.36), o que evidencia que a pessoa assume o conceito de saúde-doença como processo individual e único. Enfatiza-se aqui a velada autonomia que se coloca pelo e 
para o próprio doente, na medida em que dele dependeria a opção pelos suportes oferecidos pela familia. Verifica-se assim, que o sujeito acaba por repetir a concepção de doença como um evento estritamente singular muito possivelmente reproduzindo a forma como a própria medicina tem colocado a questão da adesão: cabe ao indivíduo optar e a não opção deve-se aqui a uma negligência pessoal.

Apesar do doente identificar o suporte dessas pessoas como de fundamental importância, verificou-se que: “o apoio/estímulo por parte dos familiares não impede a sensação de desânimo e de doença (14.18), evidenciando-se que mesmo em presença desse apoio, persistem as repercussões da doença.

Ainda que constituindo-se em investigação conduzida em país com características marcadamente distintas das do Brasil, BARNHOORN e ADRIAANSE (1992) também observaram, em estudo desenvolvido na Índia, que 56\% dos doentes que aderiram ao tratamento, em contraposição com $28 \%$ que o abandonaram, mencionaram a importância do suporte familiar durante a condução do tratamento.

POZSIK (1993), entretanto, argumenta que em alguns casos a inclusão dos familiares no desenvolvimento do tratamento pode ocasionar situações dificeis de serem contornadas. Algumas vezes, os membros da família sentem-se tão envolvidos no processo que não conseguem proporcionar o suporte "positivo" esperado e, ao contrário, comportam-se como defensores às avessas do paciente, pactuando com ele na não ingestão dos medicamentos, na tentativa de protegê-lo das dificuldades oriundas do tratamento. Essa interpretação deve ser analisada com cuidado, na medida em que introduz a idéia de que tanto o paciente como aqueles que participam do processo de tratamento, seriam "inimigos em potencial" dos serviços de saúde e que através desse tipo de comportamento, estariam sublevando a ordem institucional.

A mesma autora aponta a inclusão de outros atores no processo terapêutico, como por exemplo, professores, padres, além de outros que, supostamente, não teriam envolvimento emocional com os pacientes, o que facilitaria a contribuição destes no processo de adesão. Mas, a prática profissional da pesquisadora nas unidades de saúde que constituem o cenário do presente estudo revela que o processo terapêutico é 
sistematicamente remetido ao doente e, quando muito, essa tarefa é remetida também para o âmbito dos familiares, muitas vezes configurando uma alternativa para eximir o serviço de saúde dessa responsabilidade. Vale dizer que o processo econômico que o país vem vivenciando, ou seja, de estratégias que privilegiam o individual como mola mestra para o desenvolvimento econômico, desestimulam qualquer tipo de ação que promova a participação de outros atores sociais. Portanto, na prática, o que se tem vivenciado é que ao doente é conferida toda a carga pelo tratamento, sem que se vislumbrem alternativas, pensadas em conjunto com os trabalhadores da saúde, de apoio na região onde vive. É bem verdade que propor alternativas de suporte social junto à comunidade numa região como São Paulo, onde o processo de deterioração social é evidente, como fruto da forma como se desenvolvem as relações sociais e de produção, se constitui em uma alternativa de dificil concretização. Entretanto, deixar de levantar essa questão significaria negar que ela deve ser objeto de reflexão. $O$ refletir sobre essas questões é fundamentalmente necessário, sob pena de perder a noção de que o trabalho em saúde deve objetivar a recuperação do indivíduo e da coletividade para que usufruam de melhor qualidade de vida. Nessa perspectiva, da mesma forma como os doentes que integraram o universo da presente investigação apontam para a necessidade de que esse tipo de apoio exista de fato, verifica-se que o Programa de Controle da Tuberculose deve ser objetivado também nesse sentido, ou seja, de recuperar, no nível do coletivo, atores-chave que possam contribuir para a adesão dos doentes ao tratamento, resgatando a relação benéfica do compartir o processo de tratamento com outros.

HELLER (1991) afirma que o(s) grupo(s) social(is) ao(s) qual(is) o indivíduo pertence tem um papel fundamental pois é nesse espaço que eles se apropriam da socialidade. É nesse espaço que se concretizam os sistemas de exigências sociais, representadas pelos próprios homens ou pelas relações humanas estruturadas. $O$ desenvolvimento do sujeito, portanto, está permeado pelos processos que ocorrem nos grupos sociais que podem referir-se ao grupo familiar e/ou aos grupos comunitários. Daí que explica-se a importância do suporte desses atores na definição ou não da adesão ao tratamento, pois é no espaço do coletivo que o projeto individual se afirma e se legitima. Por isso, é mais fácil que ocorra a adesão quando o sujeito compartilha com outros a sua vivência no processo saúde-doença. 
Assim é que os depoimentos revelaram que "a adesão ao tratamento, por um dos membros da familia, estimula o seu seguimento pelos demais" (4.27, 13.7), possivelmente pelo fato de que a esfera do individual passa a integrar um universo maior, no qual o doente não mais se perceberá como único alvo da enfermidade.

Conforme anteriormente mencionado, também a participação do empregador é apontada como um dos suportes na adesão ao tratamento, tanto na modalidade de “ajuda financeira” (5.42), como “... se concentra na ingestão dos medicamentos, no impedimento do contato (fisico) com outras pessoas, na necessidade de lavagem cuidadosa de objetos pessoais, para ter/levar uma 'vida normal'” (1.10). À primeira vista identifica-se uma espécie de sustentação que parece se configurar como positiva para o doente, por estimulá-lo a dar continuidade ao tratamento. Evidencia-se, entretanto, o preconceito subliminar a essa representação, na medida em que coloca em evidência a presença de um certo grau de discriminação ao reforçar o isolamento do indivíduo. Ao mesmo tempo em que estimula a tomada do medicamento, o empregador concretiza e aprofunda o preconceito contra o doente, possivelmente em decorrência da falta de conhecimento sobre a doença e do estigma que ainda impregna o imaginário do coletivo.

Paradoxalmente, é interessante verificar nesse mesmo caso que o empregador orienta ainda o sujeito para que leve uma vida "normal", mesmo sendo portador da tuberculose, sendo que essa recomendação "provoca 'calma' no doente" (1.11). Reafirma-se assim, o caráter ambígüo dessa representação, na medida em que, simultaneamente à recomendação para que o doente siga uma série de medidas para que cuide de sua doença, faz ressaltar a necessidade de que a vida seja levada regularmente, na tentativa de anular o efeito da discriminação. Nota-se assim, uma discriminação velada, que embute o preconceito, por trás de recomendações que supostamente teriam um caráter positivo para a superação da doença.

Ainda em relação à forma como o doente enfrenta a doença através das ações e intervenções de outros, verificou-se o destaque do profissional médico: “... estimulo/valorização do profissional médico" (5.43, 12.27), mas também: “da atenção do profissional de enfermagem..." (12.27) e o "apoio de profissional da UBS 
(psicóloga)" (15.24). Nota-se, portanto, que o doente passa a incluir outros trabalhadores de saúde nesse processo, distintamente do que se revelou quando se buscava entender a sua concepção sobre a assistência à saúde. Isso é de fundamental importância, pois ao perceber a relevância da atuação dos demais trabalhadores da saúde, além do profissional médico, é porque de fato a parcela do trabalho por eles desenvolvida repercute de alguma forma para o doente nessa dimensão da produção dos serviços de saúde. A apreensão das necessidades do doente a partir da ótica das dintintas categorias profissionais possibilita um olhar distinto sobre as suas demandas e confere ao trabalho em Saúde Coletiva uma dimensão qualitativa diferenciada, materializando uma retórica que tem sido pregada, qual seja, a da transdisciplinaridade, que de fato em muitos serviços não tem se concretizado. Esse suporte possivelmente constitui-se como um dos pontos fundamentais no processo de adesão ao tratamento, ainda que esteja centrado mais uma vez na figura do profissional médico.

Além disso, as representações a seguir põem em relevo uma série de ações que apóiam a atitude do doente frente à adesão, como:

- "o apoio, o estímulo, a receptividade, por parte dos funcionários/médicos da UBS e a realização de visita domiciliária, são importantes para o doente" (10.8);

- “o sucesso do tratamento é imputado à UBS; aos funcionários que apóiam, esclarecem sobre a doença e o tratamento medicamentoso, prestam "boa assistência" $e$ manifestam receptividade para com o doente" (10.22);

- "o posicionamento do profissional médico (12.32, 17.29: do hospital e da UBS) favorece o seguimento do tratamento (indagando, prescrevendo, regulando, alertando)" (12.32).

- "o seguimento do tratamento ocorreu devido ... ao estimulo imperativo/do interesse pelo estado de saúde pela profissional médica ('cuidado... a Sra. toma o remédio direito... '), pela disponibilidade dos medicamentos..." (8.15). 
Também pôde verificar-se que: "seguir o tratamento medicamentoso determinado pelo médico é a atitude mais importante" (3.21, 9.23). Como se pode observar, a atitude do profissional médico perante o doente, direcionada para a consecução de um objetivo revela-se central na adesão ao tratamento. Em estudo já mencionado anteriormente, BARNHOORN e ADRIAANSE (1992) também verificaram que $83 \%$ dos doentes que haviam aderido ao tratamento mencionaram o suporte médico como fundamental para a sua efetivação em confronto com $58 \%$ daqueles que haviam abandonado o regime terapêutico.

Entretanto, ao mesmo tempo que a atitude do profissional de saúde frente ao doente constitui-se como mais um elemento que apóia o seu processo de adesão ao tratamento, verificou-se que: “os 'conselhos médicos' sobre a possibilidade de reincidência da doença, com piora do quadro e a ameaça de morte, contribuem para a não interrupção do tratamento" (17.24). Ou seja, o profissional de saúde também utiliza, para o convencimento do doente, de uma retórica que reforça o sentimento negativo sobre a doença. Ao invés de promover subsídios para que o doente enfrente a doença de uma forma "menos doente", o profissional reitera a enfermidade na perspectiva da fatalidade o que, evidentemente coloca para o indivíduo a possibilidade de escolha entre a vida e a morte, como se dependesse somente dos desejos particulares do indivíduo. Mais uma vez desatrela-se a noção da enfermidade da sua determinação social. É claro que não se está querendo dizer que somente imputando a doença ao social o resultado em termos de adesão poderia ser outro, mas é importante deixar claro que a participação do doente no processo de tratamento é fundamental, associada à sua consciência sobre a real causa da doença, buscando retirar do plano individual toda a carga do desenvolvimento da doença. A dupla face da doença, no indivíduo e no coletivo deve ter lugar na abordagem do processo saúde-doença, para que o doente perceba-se no interior da coletividade e compreenda que as ações que dele dependem da mesma forma orientam-se para a perspectiva da coletividade.

Dessa forma, busca-se reorientar a prática tradicionalmente conhecida que coloca o doente como aquele que deve cumprir a determinação médica, sem "... o direito de recusar o tratamento, na medida em que continuará o processo de contaminação de outros" (POZSIK. 1993). 
Observa-se que o doente espera um espaço de diálogo, no âmbito da assistência, para que suas necessidades sejam explicitadas e atendidas. Nota-se assim que ele concebe a assistência como acolhedora quando a caracteriza como promotora de apoio, de estímulo e de receptividade, que não significam apenas detalhes da assistência, mas se consubstanciam como determinantes qualitativos no processo terapêutico. Entretanto, é importante ponderar que ainda que à primeira vista a ação do profissional de saúde revele-se para o doente como acolhedora, esta de fato define-se pela prescrição, pela regulação, o que coloca em evidência que as práticas de saúde concretizam-se através da normatização e da regulação de atividades, segundo determinados padrões supostamente identificados como aqueles que conduzem à "boa saúde". Mas, pergunta-se, qual é o conceito de saúde que permeia o discurso nesse campo? $O$ que se tem verificado não revela um conceito emancipador, mas aquele que evidencia o doente acima de tudo como incapacitado, cuja responsabilidade sobre esse processo é de seu âmbito exclusivo.

Retomando o conteúdo da última frase apresentada, evidencia-se que a persuasão, mesmo quando faz uso de sentimentos de medo também pode influenciar o comportamento do sujeito, fazendo-o aderir ao tratamento, mas é importante levantar a questão de que mais dificil será a opção pela adesão a partir de atos coercitivos, punitivos, ou que façam com que o indivíduo tome para si a responsabilidade exclusiva frente à enfermidade.

GRANGE e FESTENSTEIN (1993) afirmam que, ainda que a terapêutica apropriada seja prescrita, os médicos podem contribuir para a não adesão, em decorrência de suas atitudes e comportamentos perante o doente. Afirmam os autores que o estabelecimento de uma relação de confiança entre o paciente e o médico é crucial para o sucesso do tratamento medicamentoso prolongado. Prosseguem advogando que a falta de entendimento em relação a diferenças de cultura e de atitudes dos sujeitos em relação à doença e à terapêutica, podem ser a causa de uma ruptura na relação entre o profissional e o doente. Evidentemente há infinitas representações sobre o processo saúde-doença, que são distintas para os vários pacientes. Via de regra, pouca chance é dada para que aflorem tais concepções durante a consulta no serviço de saúde, de forma a identificar possíveis dificuldades, tanto em relação à doença, como ao próprio processo de tratamento. Analisar a forma como os pacientes percebem a sua doença, bem como 
identificar como será operacionalizada a prescrição terapêutica no cotidiano do doente e de sua familia, constituem ações que devem ser levadas a cabo pelos integrantes da equipe de saúde, que passariam de meros prescritores de ordens para se constituírem também em sujeitos no processo de tratamento.

HULKA (1989), ao afirmar que a relação médico-paciente é uma importante questão na adesão, aponta para a dificuldade de se aproximar à sua natureza. A autora coloca que o "estilo de comunicação" com os pacientes pode influir na inclinação à adesão. Através do desenvolvimento de estudo em Indiana, EUA, com pacientes portadores de insuficiência cardíaca congestiva e outros com diabetes mellitus, verificou fundamentalmente que os erros na tomada de medicação aumentam segundo o número de drogas envolvidas e que esse era o principal problema não suficientemente manejado pelos médicos durante a consulta médica. A investigadora afirma que o processo de comunicação com o paciente diminui o número de equívocos que podem ocorrer durante o tratamento, indicando que informações sobre o seu desenvolvimento, sobre o curso da doença, bem como sobre as conseqüências da não ingestão dos medicamentos, dentre outras, são fundamentais para fortalecer a adesão.

Nesse sentido, a autora aponta a necessidade de que sejam escolhidos, por ocasião da terapêutica, esquemas de tratamento de fácil compreensão, compativeis com os hábitos diários do paciente. Além disso, enfoca a necessidade de difundir ao doente a função das drogas, apontando que essa oportunidade deve já estar presente a partir da primeira consulta, assinalando que isso permitiria menor número de erros na tomada de medicação. Infelizmente, via de regra, o que se verifica é que essa relação é uma "caixa preta”, desconhecida ou intocada pelos intelectuais que pensam a administração e gestão dos serviços, ou pelos profissionais que prestam a assistência, os quais, de modo geral, remetem à relação com o paciente somente as questões de ordem bio-patológica, passíveis de serem resolvidas, supostamente, através da prescrição de medicamentos. Nesse sentido, os trabalhadores de saúde teriam um papel definitivo que seria o de desmedicalizar a relação.

Ora. quando o doente busca o serviço de saúde, busca consumir as ações de saúde que para ele têm um valor fundamental, qual seja o de permitir que a sua saúde 
seja restabelecida ou mantida. A saúde tem para ele um valor de uso inestimável no sentido de que é o que o mantém vivo e de certa forma autônomo para caminhar na vida. Assim, é importante ressaltar que as estratégias que facilitam a adesão, acima mencionadas, deveriam ser fisiológicas ao cotidiano do serviço de saúde, ou seja, deveriam fazer parte (em algumas poucas unidades de saúde ainda o são), do modelo assistencial, na medida em que se referem a ações básicas e que podem garantir a adesão ao tratamento. Conforme apontam ROUILLON (1972) e POZSIK (1993), há centenas de estudos que incentivam o uso de outros tipos de estratégias, desde proporcionar alimentação ao indivíduo, até outros incentivos, como tornar o ambiente do serviço de saúde receptivo ao paciente, através do uso de filmes, de revistas na sala de espera, que poderiam promover um melhor acolhimento à pessoa. É fundamental apontar que esses são artificios que podem ser usados, mas que na realidade são complementares e não devem ocupar o lugar de uma relação trabalhador de saúde-doente diferenciada, na qual as necessidades de saúde possam realmente ser ouvidas e encaminhadas. Pensando-se a saúde como um conceito amplo, isso significa dar conta de questões que se referem ao cotidiano da assistência, mas que ao longo dos anos de abandono que o setor público da saúde vem sofrendo no país, vem sendo deixadas de lado, em prol de uma retórica da produtividade e da eficiência, redundando em práticas de saúde com baixa resolutividade em termos de acesso e qualidade de vida, bem como alijando o doente de ser cidadão.

Isso significa que o sucesso do programa de controle depende de que este esteja centrado nas carências que o doente e a coletividade apresentam e não no circuito fechado conformado pela instituição de saúde. Assim, a organização do serviço é que deve se constituir em subsídio para a promoção da adesão e não o contrário, conforme vem sendo operacionalizado nos dias de hoje.

As brechas para a reorientação da assistência poderiam ser criadas a partir da utilização de novas práticas, ou de outras, que são efetivas, mas que, de modo geral , têm sido deixadas de lado. Conforme verificou-se no presente estudo, o doente aponta determinadas ações, como a visita domiciliária, como importantes para o seguimento do tratamento, possivelmente por ser esse ainda o momento através do qual o doente se sinta mais à vontade para exteriorizar suas necessidades. Ainda no que se refere ao âmbito da organização dos serviços de saúde, vale apontar que a "disponibilidade dos 
medicamentos" (8.15), "a distância da UBS à moradia” (12.27), foram evidenciadas como pontos fundamentais na adesão. Nessa perspectiva, observa-se que é necessário que o Programa de Controle de fato disponibilize o medicamento. É inadmissivel pensar na falta de medicamentos para a tuberculose, quando se defende o desenvolvimento de alta tecnologia para outras patologias, que muitas vezes não alcançam relevância epidemiológica, mas se constituem em reservas importantes para a atuação das indústrias farmacêuticas, bem como para aquelas relacionadas aos insumos para a prática da medicina. Vale salientar ainda o fato de que o doente aponta como importante a distância da unidade de saúde ao domicílio como outro elemento que facilitaria a adesão. $\mathrm{Na}$ realidade, o que se verifica é que o doente necessita de um mínimo de organização do serviço de saúde e de descentralização do atendimento, de tal forma que o tratamento da doença possa ser efetivado. Na prática se recupera aqui a noção de uma estrutura de saúde funcionante, que vai proporcionar ao doente a satisfação de suas necessidades.

Analisando-se a questão da adesão em outra esfera, é importante verificar que, via de regra, existe para o doente, um "norte" a seguir quando se trata de completar o tratamento, o qual parece ser materializado por um projeto de vida ou verdadeiramente uma necessidade projetada de superação da vivência da doença e do tratamento. Parece que o fato de submeter-se ao tratamento depende da existência de um projeto, uma meta, que se consubstanciam no desejo de cura por parte do sujeito enfermo: "vislumbre do futuro" (9.18). E a cura é concebida como "uma possibilidade que depende do seguimento do tratamento" $(13.14,16.10)$, ou: "o seguimento do tratamento ocorre pela necessidade e crença na melhora" $(13.8,18.19)$ e devido "à projetos/objetivos relativos ao futuro (17.34). A projeção da cura pelo doente parece ser um processo tão significativo que mesmo: "os momentos dificeis vividos durante a doença são minimizados por ocasião da cura" (12.30). Ou seja, o voltar a estar saudável faz abandonar a imagem/lembrança das dificuldades ocorridas por ocasião do desenvolvimento da doença.

Por um lado, esse projeto é colocado em função de algo que parece ser intimamente particular, individual, ou seja, que parte do sujeito especificamente e que depende de suas "qualidades" para a concretização, como: " 'teimosia' e de obstinação ('querer ir até o fim')" (2.43), “de otimismo” (11.19), “à força de vontade, à “vontade 
de sarar' (6.17), à boa vontade do doente" (10.22), "pela auto-estima (14.55), "da pessoa pensar, em primeiro lugar, em si mesma" (13.20), "ao esforço da doente (para alimentar-se)" (17.33), 'da vontade de melhorar' (4.17); "ao desejo/ vontade de 'ficar bom'” (2.41, 9.18), "devido ao desejo de cura" (10.14, 11.21, 16.12), "da confiança na possibilidade de cura" (12.27), "ao desejo de 'ter saúde"' (8.15), por 'amor à vida' (15.23), "da sua valorização em função da vida como um bem maior" (12.27, 14.55, 17.34), "de ter vontade de viver" (14.58), “...pela persistência/disciplina para, em última instância, poder modificar a vida.. e por não ter que vivenciar a doença" (7.14).

Cabe destacar as seguintes representações: "o sucesso do tratamento depende... de disciplina (11.19) e, "do dever ("tenho que tomar")" (4.17), o que revela que a adesão se configura quase como uma obrigação, de responsabilidade individual a ser cumprida para a cura: "o sucesso do tratamento está ... no entendimento de que a força para executá-lo provém do próprio individuo (14.58). Além disso, é importante destacar o conteúdo da frase temática a seguir, que evidencia que o seguimento do tratamento ocorreu tendo em vista "a possibilidade de voltar ao "estado normal" (17.34).

Verificou-se ainda que: "o seguimento do tratamento adequado ocorre devido à prontidão/alerta para tomar os medicamentos e porque o organismo "se acostuma" aos medicamentos" (16.7). As representações anteriormente mencionadas parecem colocar em evidência o fato de que é necessário que a pessoa se sinta especialmente motivada para que a recuperação de seu corpo se constitua como uma necessidade, além de colocar em pauta o conceito de autonomia na medida em que a definição por tomar ou não a medicação dela depende. HELLER (1991) argumenta que a autonomia ocorre quando, na eleição entre alternativas, a resolução está marcada pela individualidade da pessoa. Ao colocar que a atividade cotidiana está composta por uma série praticamente infinita de eleições, que estão subjugadas à posição ocupada pelo individuo na sociedade, constitui-se portanto a autonomia como relativa. Segundo a mesma autora: “... em sua vida cotidiana os homens podem querer coisas distintas. O que podem querer deriva em primeiro lugar das relações sociais e do lugar que os homens ocupam em seu seio". 
Assim, a opção pela adesão como uma alternativa para a reabilitação do corpo com a finalidade de mantê-lo ativo no processo de produção e reprodução social deve levar em conta o fato de que o sujeito perceberá esta necessidade na medida em que ocupe um determinado lugar na sociedade, mais especificamente no processo de produção. O seu alijamento desse processo imprimirá uma outra forma de se relacionar com a sociedade, onde a motivação maior deixa de ser o que anteriormente foi colocado. A exclusão social leva um processo de alijamento também da particularidade, ou seja, da concretização do eu na sociedade. Os grupos que se encontram à margem da produção, os quais em geral constituem-se na população mais exposta aos riscos de contrair a tuberculose e que também, via de regra, encontram maiores dificuldades em aderir ao tratamento, são aqueles que tanto a sociedade, como os trabalhadores de saúde, qualificam tradicionalmente como "negligentes", o que é fruto de uma interpretação discriminatória e excludente. Na medida em que essas pessoas se encontram à margem do processo de produção, podem perder, dentre a sorte de direitos inerentes ao ser cidadão, a perspectiva de tomar como necessidade a manutenção de seu corpo. Assim, para estes, há que se proceder à leitura da adesão enquanto uma necessidade social, no interior da qual é fundamental tornar esses excluidos, em primeira medida, como cidadãos. Não se trata, portanto, de estabelecer medidas de coerção que levem ainda mais à exclusão, ao afastamento, mas é necessário um movimento de re-inserção destes na sociedade. A discussão remete à exigência de intervenções profundas a partir do Estado, uma vez que à esta esfera cabe a re-inserção dessas pessoas no tecido social, não se tratando apenas de uma questão de iniciativa própria ou de força de vontade que dependa unicamente do indivíduo.

Um outro aspecto que foi verificado é que a adesão ao tratamento ocorre pois parece existir uma motivação decorrente de algum aspecto negativo que tenha passado com o doente ou com pessoas que de alguma maneira com ele convivem: "o seguimento do tratamento ocorre em decorrência do ... vivenciado em função da mesma doença por amigo (perda de pulmão) e do medo da morte" (5.43).

O fato de ter enfrentado o processo saúde-doença com todos os potenciais percalços que pode causar, ainda que contraditoriamente, também se constitui em motivação para que o doente siga o tratamento de maneira completa: "a necessidade de 
ingestão dos medicamentos ocorre devido ao não querer re-vivenciar a doença/tb" (7.14, 9.18). Ou: “a possibilidade de sofrer as conseqüências da interrupção do medicamento, determina a continuidade do tratamento" (13.18). Chama a atenção ainda a forma como o doente apreende o processo, na medida em que: "o seguimento do tratamento se constitui em obrigação para viver" (12.29).

Evidentemente que ainda que o desejo de cura parece ser basicamente da mesma natureza entre os indivíduos, provavelmente se apresenta de maneira diferente para os diferentes grupos sociais, tanto no seu sentido simbólico como ideológico. E isso pode ser explicado, conforme lembra LEOPARDI (1992), ao fundamentar-se na teoria das Necessidades de Agnes Heller, porque a necessidade de saúde apresenta diferentes representações, relacionadas com o grau de limitação física e social que a doença impõe. Além disso, porque os objetos de satisfação se distribuem nos grupos sociais segundo determinantes políticos, econômicos e culturais.

Segundo HELLER (1991), o reconhecimento do caráter real de uma necessidade não implica automaticamente no reconhecimento de sua legitimidade. Existe uma discrepância fatal e insuperável entre as expectativas e a experiência, dado que as primeiras estão imbuídas da contingência, enquanto que, no caso da segunda, se concretizam os fatos duros da vida, a limitação factual das possibilidades, que se constitui em fonte constante de insatisfação e de descontentamento.

Destaca-se um outro aspecto importante que se refere ao fato de que algumas das necessidades concretas nunca serão atendidas, inexistindo a possibilidade da satisfação da vida como um todo, uma vez que a satisfação maior e mais profunda nunca será garantida. A satisfação completa das necessidades é um conceito equivocado, como o é o conceito de saúde-doença que se refere ao completo bem-estar fisico e psíquico. A plenitude, que tem um cunho altamente ideologizado, significaria o fim da luta e da busca, o que significaria na renúncia ao desenvolvimento de qualquer projeto subseqüente (HELLER, 1991). Aqui vale a pena recuperar a interpretação de MERHY (1996) sobre a categoria necessidade. Indo além do senso comum, que confere à necessidade uma imagem de carência, como falta de algo que se busca consumir, o autor afirma que as necessidades adquirem uma outra dimensão, na medida em que expressam 
potencialmente o que é desejado. É nesse sentido que o doente buscaria então o projeto, ao mesmo tempo representado como necessidade, para transformar o seu modo de vida. Dessa forma, ainda que se aponte para um projeto ou meta a serem conseguidos ao final do tratamento, esse projeto é relativo, pois o processo de vida é dinâmico. Entretanto, o fato de ser estabelecido ou apontado como algo a ser conseguido, parece se constituir em uma necessidade que impulsiona a adesão ao tratamento, e que possibilita o balanceamento e a superação das dificuldades que este impõe.

Assim, outros elementos ajudam a compor o cenário no interior do qual o doente realiza o tratamento até a sua finalização: "a busca pela melhora da sintomatologia determina o seguimento do tratamento completo" (1.23). E esse é um ponto de interesse fundamental, na medida em que, de modo geral, conforme discutido anteriormente, existe uma certa tendência a deixar de fazer uso da medicação, quando o doente deixa de perceber a sua necessidade. É evidente que esse comportamento está correlacionado à forma como se interpreta a saúde e a doença, pois na medida em que se visualiza a saúde como ausência de sintomatologia, será esperado que o doente deixe de ingerir a medicação quando os sinais e sintomas desaparecerem. É interessante verificar a análise que fazem GRANGE e FESTENSTEIN (1993), a respeito da palavra inglesa "disease" que, para muitos, significa dis-ease: “a sense of lack of well-being”, o que quer dizer a perda da sensação de bem-estar. Assim, na falta/inadequação de informações sobre o tratamento, os doentes poderiam falhar na sua continuidade. Sobre essa questão, pode-se ainda tomar o exemplo de SHEARS (1984) que, no desenvolvimento de um estudo em um campo de concentração de refugiados somalis relata que a mais freqüente causa de falha no tratamento era a perda de interesse no mesmo, uma vez que os pacientes sentiam-se bem para o desenvolvimento das atividades do cotidiano.

SUMARTOJO (1993) faz referência ao estudo de Dubanoski, cuja finalidade era a de estudar os preditores da adesão ao tratamento em trabalhadores no Hawai. O autor afirma que a adesão se constitui como um comportamento influenciado pela intenção inicial do doente para tomar a medicação. Ademais, esse comportamento é influenciado por fatores sociais e pessoais, enfatizando que, no caso daqueles que aderem ao tratamento, há sentimentos que ajudam a lidar com as demandas do regime terapêutico, crença na eficácia das drogas e suporte de outras pessoas do seu círculo de convivência. 
Aponta ainda que o mais importante preditor que revelou-se durante a realização do estudo foi a adesão após um mês de terapêutica, sugerindo a necessidade de estabelecer, precocemente, intervenções com os doentes que parecem ter possibilidade de não aderir ao tratamento.

Uma outra perspectiva que se coloca é que, segundo GORDIS (1989) a adesão partiria de questões externas ao âmbito do relacionamento entre o profissional de saúde e o doente, e que estariam relacionadas a aspectos inerentes às drogas. Aponta, nesse sentido, a presença de elementos associados à farmacocinética das drogas no ser humano, cuja ação muitas vezes não é facilmente controlada e algumas vezes até desconhecida, resultando na possibilidade da melhora da doença não quando o tratamento é instituído. A não consecução da melhora da doença poderia também repercutir na adesão.

Por outro lado, a consecução do projeto/meta também ultrapassa o plano do indivíduo e se remete à outras dimensões: "o seguimento completo do tratamento é produto da "vontade de viver" $e$ da necessidade de criar os filhos" (10.23), "o seguimento do tratamento pelo doente é motivado pela necessidade de cuidar da filha (menor de idade)..." (7.14) e, “... por acreditar que os membros familiares necessitam do doente (14.55). Ou seja, na ultrapassagem do projeto individual, se coloca em cena a necessidade de curar-se para servir e cuidar de outro, o que evidencia que o processo saúde-doença não se limita ao corpo individual, mas traz repercussões em planos distintos, que se referem ao âmbito familiar e também do coletivo de maneira geral.

Além disso, verificou-se que o seguimento do tratamento está atrelado à necessidade de “de continuar a trabalhar" (6.17) e da: “...possibilidade de continuidade do afastamento do trabalho e suas repercussões econômicas" (11.21). Como pode se verificar existe um impulso para a adesão que é orientado por certos projetos determinados pela necessidade de viver do doente. Aos doentes que já se encontram engajados no sistema de produção, parece existir um motivo para a continuidade da vida, mesmo porque são pessoas que, ainda que precariamente, integram parte do processo econômico, enquanto força de trabalho. Conforme pode ser visto em uma série de dados da literatura, os maiores problemas relacionados ao abandono do 
tratamento parecem estar localizados naqueles que têm sido taxados por uma série de qualificativos como alcoolistas, doentes mentais e sem teto. Mas é fundamental refletir que todas essas características são de fato "anormalidades" da sociedade atual, que se constituem como fruto da própria forma como está estruturada a sociedade, na qual uma parcela da população que cresce inexoravelmente, tem sido colocada à margem da produção. A adesão, portanto, se encadeia como um produto de uma certa forma de poder situar-se na sociedade. Não se está falando aqui do fato de que a adesão somente ocorre a partir de uma série de condições ou de situações ideais, mas o que se quer deixar claro é que a adesão parece estar diretamente associada às condições sociais. Isso inclui, portanto, uma base constituida por serviços de saúde que acolham as necessidades dos grupos que os procuram, como também a necessidade de ser cidadão e poder exercer a cidadania junto aos pequenos grupos sociais e junto à coletividade de maneira geral. A persistir o desmantelamento do setor público, a redução do Estado na defesa dos interesses do tecido social, bem como as conseqüências advindas da instauração do modelo econômico neoliberal que determina o aumento do desemprego, aprofundando a exclusão de determinados grupos sociais, poder-se-á assistir a aceleração da incidência dos casos de tuberculose, conjugada a problemas dificeis de reverter em relação à adesão ao tratamento.

Ora, como pôde ser verificado, a maioria das frases temáticas traz em seu conteúdo representacional, a projeção de algo maior, que transcende a doença em si mesma. Existe um projeto, uma "esperança" que, conforme advoga MENDESGONÇALVES (1995) se constitui como uma “(...) condição ideal na qual os seres humanos podem ter motivações reais ao se dirigirem comunicativamente aos outros seres humanos". E essas motivações estariam ancoradas em possibilidades de mudança da própria vida e/ou da sua vida em relação ao convívio no coletivo. É nessa perspectiva que HELLER (1991) delimita o conceito de motivação, quando parte do ser humano singular em relação dialética com a sociedade. Ela coloca as motivações particulares como advindas das caracteristicas particulares que sofrem transformações no decorrer da vida em sociedade. Uma vez que o cotidiano é heterogêneo, as emoções, o uso das sensações, da motivação, não ocorrem sempre da mesma forma, ou ao mesmo tempo. A cotidianidade ou a não cotidianidade de uma motivação não dependem da intensidade $e$ nem do conteúdo de valor, mas sim do objeto, do fim, do objetivo que suscita a 
denominada paixão dominante. A concretização do projeto resultaria, portanto, da sintese entre as motivações particulares determinadas pelos processos sociais mais genéricos.

É interessante notar que HELLER (1991) advoga que a luta pelo trabalho, pelo posto de trabalho e pela ascensão no trabalho, são os campos mais importantes nos quais se manifestam as motivações particulares, não significando que a atividade laboral opere com exclusividade essas motivações. Mas isto poderia auxiliar na explicação do porque a adesão ocorre, na medida em que o processo saúde-doença está inerentemente ligado ao trabalho e é determinado pelo social. $\mathrm{O}$ alijamento do indivíduo desse processo, em virtude da doença, materializaria a adesão como uma necessidade para a sua re-inserção no mesmo. Evidentemente que a marca do singular, do indivíduo, imprime graus diferenciados de comportamento que por sua vez irão repercutir na adesão. Trata-se pois de resgatar a singularidade, entendendo que está circunscrita à totalidade. Essa deve ser a verdadeira lacuna que deve ser recuperada no âmbito da assistência, na medida em que os marcadores para a adesão ao tratamento muitas vezes não se encontram claramente explicitados, mas é no cotidiano da produção dos serviços de saúde, através de uma relação entre o trabalhador de saúde e o doente que se revele como um espaço de troca que se compreenderá a potencialidade para a concretização ou não da adesão.

A adesão ao tratamento com base num projeto que o sujeito coloca para ser alcançado tem ainda suas bases nas afirmações de HELLER (1970) quando advoga que a proposição de um projeto convoca da parte do indivíduo a inteireza das forças ocorrendo nesse momento uma objetivação. Nesse sentido, a necessidade de saúde integraria um plano de objetivação maior que seria carreado ora pelo trabalho ora pela reprodução social. Essa objetivação possibilita a transformação do cotidiano singular em coletivo.

No decorrer da construção das frases temáticas, verificou-se que há outros elementos que têm papel na sustentação da adesão ao tratamento: “ ... a não exposição a substâncias frias/geladas/ambiente frio, bem como 'fazer tudo certo', principalmente durante o primeiro mês, são as atitudes mais importantes durante o tratamento" (1.24). 
Também questões relacionadas à organização do serviço são definitivas para incrementar a adesão e se referem tanto à eficiência em relação ao tempo, como ao acesso físico propriamente dito, como a não necessidade de internação:

- "A qualidade da assistência prestada na UBS e no Instituto Clemente Ferreira, materializada pela priorização no atendimento, em função do diagnóstico de tuberculose, é indicada como um item importante no seguimento do tratamento" (4.35).

- "A facilidade de acesso, a rapidez de atendimento e a não necessidade de internação, são apontados como fatores que auxiliam no seguimento do tratamento" (6.16).

- "A organização do serviço de saúde (agendamento de consultas) é apontada como um item importante no seguimento do tratamento" (4.37).

Como pode ser visto, explicitam-se como conteúdos representacionais dos entrevistados, alguns aspectos inerentes à organização dos serviços de saúde, que nada mais se referem do que à efetivação dos princípios que orientaram o estabelecimento do Sistema Único de Saúde no Brasil (BRASIL, 1992). Dentre todos os princípios que constituem o ideário do SUS, ressalta-se aqui o da descentralização, que se operacionaliza pelo atendimento ao doente em local mais próximo ao seu domicílio, e que de fato, responderia às necessidades do sujeito enquanto cidadão. GRANGE e FESTENSTEIN (1993) defendem esse princípio, colocando que as grandes distâncias a serem percorridas pelos doentes para a busca da assistência à saúde têm sido reconhecidas como fator associado à não adesão ao tratamento, especialmente se o paciente é responsável pelo pagamento do transporte para deslocar-se até a unidade de saúde. A descentralização das ações da tuberculose para unidades de saúde regionalizadas contribui definitivamente para a garantia do acesso dos pacientes aos serviços de saúde, possibilitando ainda com que estes desenvolvam ações "apropriadas" às necessidades locais, uma vez que seriam dirigidas a grupos supostamente conhecidos em termos de carecimentos de saúde. 
Em um plano diferente do que anteriormente foi mencionado, outros elementos ajudariam a interpretar em que sentido os doentes compreendem os elementos que dificultariam a adesão ao tratamento: "a assistência d̀ saúde, concretizada pelos retornos subseqüentes às consultas médicas; pela falta de seqüêncialobjetividade na abordagem do médico por ocasião dos retornos; pela falta de profissionais "especialistas"; pela associação da manifestação da tuberculose à AIDS pelo médico; pela necessidade de exame de escarro (cujo material não mais existia)..." (7.24). POZSIK (1993) analisa amplamente as situações que potencialmente podem repercutir negativamente sobre a adesão, destacando dentre estas, a forma como a instituição de saúde organiza suas ações.

Como pode ser visto, existe uma concepção sobre a qualidade da assistência esperada pelo doente: de que seja eficiente, objetiva, que seja operacionalizada por profissionais que evidenciem o seu conhecimento específico sobre a doença. Além disso, espera-se que os trabalhadores de saúde não incorporem em seus processos de trabalho, conceitos permeados pelo preconceito. Em virtude do fato de que a tuberculose encontra-se muitas vezes associada à AIDS há que se verificar, no cotidiano da assistência, que o raciocínio médico deve ser realizado de forma que o doente entenda a razão, tanto das questões que conformam a anamnese, como a forma como se constrói o diagnóstico provável. $\mathrm{O}$ desenvolvimento da consulta médica, muitas vezes pensado como "inócuo" para o médico, se efetiva para o doente como um momento de indagação, desconhecido e que pode levar ao encadeamento de associações fantasiosas que, mais do que tudo, podem vir a potencializar o processo de angústia frente à sua fragilidade em relação à doença.

Para os doentes que aderem ao programa, o tratamento medicamentoso é incorporado como fundamental $(11.19,12.20,14.58,18.20)$, como pode se depreender das frases temáticas a seguir, ampliando-se ainda à adoção de outras ações : "o sucesso do tratamento depende também do uso de ações caseiras ('inalação com eucalipto')" (5.33), "do tratamento caseiro" (12.20), "do uso de substâncias naturais (ervas)" (7.23, 12.21), “benzedeira, chá" (3.18), "de alimentação nutritiva" (9.16, 11.19, 11.24, 15.24), ou: "a ingestão de alimentos, ainda que sem gostar, é tida como um dever para atingir a cura" (14.11) e, "a ingestão aumentada de líquidos e de 
alimentação" (1.16), "da não ingestão de álcool e uso de fumo, ao não uso de drogas" (14.58) e "inclui a não exposição ao frio" (2.38). Assim como: "o repouso e a manutenção do contato com amigos são as medidas mais importantes durante o tratamento" $(5.42,5.44)$. Aqui se evidencia a necessidade da continuidade do convívio do doente com a sociedade, deixando claro que o processo enfermidade não deve alijar a pessoa do tecido social. Medidas coercitivas, como a hospitalização, por exemplo, devem ter valor apenas em casos bastante específicos, muito possivelmente somente para as formas graves, para os casos que apresentem multirresistência, ou em determinadas situações sociais. Necessário se faz comentar ainda que o próprio doente faz referência ao uso de determinadas medidas que, na realidade, põem em evidência um retorno a uma vida regulada ou regrada, conforme foi apontado pelos próprios doentes quando se fazia menção às concepções que emergiram em relação à tuberculose.

Conforme pôde ser visto através da análise dos depoimentos das pessoas que efetivaram o tratamento integralmente contra a tuberculose, a adesão se constitui em uma questão que absolutamente não pode ser examinada somente da perspectiva comportamental, inerente ao doente. A adesão está intrinsecamente conectada à dimensão singular, do indivíduo, mas esta se interrelaciona com as demais dimensões da sociedade, quais sejam o âmbito da conformação dos grupos sociais e a esfera da estrutura da sociedade, ou seja, do aparato jurídico-político-ideológico articulado ao modo de produção, pois conforme afirma HELLER (1970) o homem não é só singularidade, mas ao mesmo tempo, singular e genérico.

Foi possível verificar que o indivíduo completa o tratamento em função de uma determinada concepção sobre o processo saúde-doença, onde está presente a contraditoriedade de que o medicamento faz melhorar, ao mesmo tempo em que é algo que deve ser incorporado ao seu cotidiano e como tal, não é "fisiológico, ou natural" à sua vida. Além disso, a adesão concretiza-se em virtude do estabelecimento de um projeto que está vinculado à sua posição no processo de produção e de reprodução social. Está sujeita pois à forma pela qual o doente está inserido no trabalho e ao espaço que este dispõe quanto às possibilidades do atendimento às necessidades advindas do processo saúde-doença. Depende também da sua posição frente ao grupo ao qual pertence mais particularmente e, nesse sentido, em geral, é ao grupo familiar que o 
doente tem demandas especificas a atender no que se refere ao seu papel como provedor desse grupo, tanto em relação ao aporte financeiro como ao que dele se espera na figura de responsável. Em função disso, a adesão se coloca como uma necessidade para a consecução do projeto de vida. Segundo HELLER (1991), ainda que na aparência o projeto possa revelar-se como individual, ele se remete aos planos mais gerais da constituição da sociedade. Segundo a autora, o ser humano percebe e manipula o mundo partindo de si mesmo e quando se apropria do mundo ele o faz com o objetivo de autoconservar-se, colocando teleologicamente a sua consciência e seu eu no centro do mundo. A autoconsciência é a consciência do eu mediada pela consciência da genericidade. Assim, os projetos, os desejos, as motivações, que parecem ser singulares estão subjugados à sua posição na sociedade.

A concretização da adesão depende do suporte de certos atores no processo, incluindo aqueles que pertencem ao seu grupo social, familiar ou do trabalho principalmente, mas também depende do suporte promovido pelos trabalhadores da saúde na dinâmica da produção da saúde. A forma como se dá essa produção das ações de saúde, ou seja, através de um processo de troca de informações, de valorização das necessidades que o sujeito apresenta, incluindo as relações que se estabelecem entre o produtor e o receptor dos serviços restringe as possibilidades do abandono ao tratamento. Conforme outros estudos já mencionados demonstraram, verificou-se também que a adesão depende da capacidade das drogas causarem efeitos colaterais, bem como do período de tempo em que devem ser administradas.

Tomando como referência a declaração da Organização Mundial da Saúde de que a falta de adesão ao tratamento é um dos mais importantes problemas a serem enfrentados (WORLD HEALTH ORGANIZATION, 1993b) e a partir dos achados que o presente estudo revelou, é necessário considerar que a tuberculose deve ser analisada de forma mais global, que leve em consideração o doente na sua posição e relação com a sociedade, bem como a forma como são estabelecidas as políticas para o controle da enfermidade. Nesse sentido não se pode deixar de mencionar que a falência do tratamento repercute sobre os perfis epidemiológicos, como também onera o preço do tratamento contra as cepas resistentes do bacilo que causa a tuberculose (BAYER e DUPUIS, 1996). Assim, por um lado, urge que sejam adotadas estratégias que 
determinem um impacto no controle da doença, uma vez que, infelizmente o que se tem verificado é que a adoção de um modelo econômico de caráter essencialmente excludente, traz a possibilidade potencial do aumento progressivo de pessoas privadas dos benefícios sociais. Por ser a tuberculose uma enfermidade essencialmente de cunho social, há que se esperar, lamentavelmente, que a sua incidência se eleve, com as repercussões que isto pode causar, tanto em termos de disseminação da doença, como no que se refere às possibilidades de aumento da multirresistência às drogas, em decorrência da baixa adesão ao tratamento que esse grupo de pessoas em geral apresenta. É evidente que do ponto de vista desses sujeitos marginalizados pela sociedade, o tratamento contra a doença possivelmente não se coloca como uma necessidade de primeira ordem, uma vez que estão afetados por carências muito mais profundas e que se relacionam com a sobrevivência. É fundamental ter em conta que estes são potenciais disseminadores da enfermidade e que necessitam de práticas de assistência diferenciadas, que revelem inicialmente a recuperação desses sujeitos enquanto cidadãos. Não bastam, portanto, estratégias que coloquem a unidade de saúde à espera dos doentes, mas há que se proceder exatamente ao revés, ou seja, estabelecer processos de vigilância epidemiológica que retirem o trabalhador de saúde dos muros do serviço de saúde, onde as contradições em termos de carecimentos de vida são muito menos exacerbadas que a realidade que se constrói externamente e proceder a intervenções em conjunto com a coletividade que superem a situação ora existente.

Atualmente constituindo-se como o "estado da arte" em relação à tuberculose, conforme apontado na Introdução da presente investigação, uma das alternativas que têm sido largamente utilizadas no âmbito internacional, na tentativa de ampliar a adesão dos pacientes ao tratamento, refere-se ao tratamento realizado sob supervisão, seja do trabalhador de saúde ou de outros integrantes da sociedade. Essa estratégia, entretanto, não se constitui em novidade, tendo sido empregada já no final da década de 40 , quando investigadores britânicos fizeram seu uso em ensaios de quimioterapia na África, Ásia e na Europa, especificamente em Londres (CASTELO FILHO, 1993).

Há uma riqueza de experiências que relatam o emprego dessa estratégia, via de regra enfatizando os seus resultados positivos (BRAUSCH e BASS, 1993). Vale a pena sintetizar aqui alguns relatos que destacam a forma como o tratamento sob supervisão 
tem sido adotado em diferentes países, ainda que se desenvolva em contextos sociais bastante distintos do brasileiro, na tentativa de mostrar alternativas que poderiam ser aplicadas sem que os custos fồssem maximizados, mas que certamente dependem de uma forma distinta de organização dos serviços de saúde, bem como de vontade política no que se refere à mudança da situação de saúde no país.

A literatura mostra várias referências desse tipo de prática, como por exemplo, 0 estudo de KUMARESAN e MAGANU (1992), que ao analisarem casos de tuberculose no início da década de 90 em Botswana, afirmavam que, a partir de uma taxa de adesão de $60 \%$, a adoção do tratamento supervisionado determinou a adesão ao tratamento em 92,3\% dos casos. Defensores da estratégia, na medida em que proporcionou resultados efetivos em termos do aumento da adesão ao tratamento, os autores advertem, entretanto, para a necessidade de avaliação dos custos do seu emprego.

$\mathrm{Na}$ Inglaterra, o tratamento supervisionado tem sido recomendado para os pacientes que abandonam o tratamento e para aqueles que os profissionais de saúde julgam como potenciais no abandono do processo (HIV, 1997), enquanto que nos EUA o seu emprego se tornou usual como padrão de tratamento a partir de 1993, “...como parte de uma resposta desesperada ao ressurgimento da tuberculose relacionada com o $\mathrm{VIH}^{8}$ e a emergência de resistência medicamentosa múltipla relacionada com vários surtos institucionais" (MORSE, 1996). Os Centers for Disease Control, dos EUA, ao publicar uma proposta estratégica visando a ambiciosa eliminação da tuberculose antes da virada do século, alertava para a necessidade de que o país deveria implementar programas visando o tratamento de doentes portadores de tuberculose através da instituição do tratamento supervisionado (CENTERS FOR DISEASE CONTROL, 1989).

Assim, em Mississipi, nos EUA, HOTCHKISS (1993) relata o desenvolvimento de um projeto piloto que contou com a participação de enfermeiras que se mostravam frustradas com a freqüente falência do tratamento e necessidade do prolongamento do

\footnotetext{
${ }^{8}$ VIH: Vírus da Imunodeficiência Humana.
} 
esquema terapêutico devido ao abandono. A introdução do tratamento diretamente supervisionado por esse tipo de profissional teve bons resultados quanto ao aumento da adesão, o que fez com que essa prática fôsse adotada como padrão para todos os pacientes daquela região.

Atualmente os Centers for Disease Control recomendam que todos os doentes devem ser considerados como alvo potencial do tratamento supervisionado, ressaltando, no entanto, que em realidades que apresentem $90 \%$ de adesão ao tratamento, a estratégia poderia ser focalizada somente para aquelas pessoas que evidenciassem prospectivamente possibilidades de abandono (CENTERS FOR DISEASE CONTROL, 1993a).

No Brasil essa prática está começando a ser adotada e no Estado de São Paulo há relatos de que ela tem sido empregada em determinadas regiões, integrando um projeto cuja finalidade é proceder à assistência à saúde de uma forma diferenciada, a partir da perspectiva da comunidade. Aqui se faz referência ao denominado Projeto "Qualis", da Secretaria de Saúde do Estado de São Paulo, que teve início há cerca de um ano.

ISEMAN et al. (1993) também defendem a estratégia e procedem a interessante análise ao apontar que, ainda que “...o tratamento supervisionado pode se consubstanciar como um medida "draconiana", os efeitos adversos sobre o indivíduo e a sociedade são substancialmente menores que os efeitos de dois anos de tratamento em um sanatório". Esses autores relatam o emprego de trabalhadores da comunidade para exercer a supervisão dos pacientes, tendo essa prática evidenciado resultados bastante promissores, uma vez que essas pessoas apresentam maior facilidade de "trânsito" na comunidade onde residem os doentes.

Um dos principais argumentos que têm embasado a estratégia do tratamento supervisionado, refere-se à flexibilidade no agendamento com os pacientes, na medida em que possibilita o encontro com o doente em local factível e estabelecido de comum acordo entre ele e o profissional de saúde. Isso não implica que necessariamente o local a ser visitado pelo profissional de saúde será o domicílio de residência do paciente, ou seu 
local de trabalho, mas poderá ser algum outro local intermediário e de fácil acesso para ambos (POZSIK, 1993).

Destaca-se que existe um movimento, principalmente em algumas localidades onde parece existir uma visão diferenciada no que se refere à necessidade do acesso aos benefícios sociais, para a adoção de estratégias que combinam ações relativas à detecção de casos e tratamento supervisionado. Um exemplo dessa prática é o que vem sendo desenvolvido na cidade de Nova York, nos EUA, que segundo dados de literatura, deu início ao controle da tuberculose já em 1893, através de levantamentos epidemiológicos para o rastreamento de doentes, da terapia supervisionada e do confinamento dos clientes que não aderiam ao tratamento (LERNER, 1993). Vale lembrar que na localidade, a prevalência da tuberculose atingiu um pico de quatro vezes a taxa nacional no início da década de 90 , exibindo como características principais a disseminação nosocomial, acompanhada da multirresistência às drogas, principalmente a isoniazida e rifampicina. $O$ desenvolvimento de um projeto que envolveu vontade política aliada a um financiamento importante, utilizou a estratégia do tratamento supervisionado, o que resultou na redução da prevalência da resistência adquirida às drogas, as recidivas $\mathrm{e}$, espera-se a longo prazo, a redução da resistência primária às drogas (HIV, 1997). Além disso é importante destacar que, nessa localidade, há uma lógica na organização dos serviços de saúde, cuja base é constituída pelo princípio de que a instituição de saúde deve dar conta de servir aos doentes, antes do estabelecimento de medidas coercitivas que privem os individuos de usufruir de sua liberdade.

Entretanto, a prática do tratamento supervisionado tem provocado posicionamentos contrários, entre os quais destaca-se o fato de que se constitui como um potencial desperdício de recursos num universo já escasso. Na mesma linha, destacase que o tratamento supervisionado pode se tornar como uma estratégia de intrusão, ao agredir o princípio da autonomia dos sujeitos (ANNAS, 1993). Também a hospitalização é questionada, conforme pode-se verificar através das referências de BAYER e DUPUIS (1996), o The New York City Tuberculosis Working Group defende que: "é ilegal e carece de ética ... que se confinem pessoas que abandonam o tratamento, antes de fazer esforços para determinar as causas da não adesão ao tratamento....". Da perspectiva desse Grupo, o governo que falha na provisão de suporte social para aqueles que 
apresentem maior vulnerabilidade, perde a autoridade, a moral e a legalidade para privar a liberdade daqueles que possuem comportamento tido como de risco. Evidencia-se assim, uma postura diferenciada da responsabilidade do Estado frente aos problemas do coletivo, ao deixar de tratar a questão como meramente individual.

Vale dizer que as práticas do tipo coercitivo, como aquelas que impõem o tratamento aos doentes, realizam visitas de caráter surpresa às casa dos doentes, bem como aquelas que levam ao confinamento, cada vez mais têm sido condenadas. Para alguns pode parecer paradoxal o fato de que o Estado teria uma força limitada sobre a sociedade, na medida em que poderia agir para proteger o coletivo, mas não para proteger o indivíduo das consequiências de seu próprio ato. Entretanto, o argumento defendido é o de que em primeiro lugar se coloca o conceito e a materialidade da liberdade a ser usufruída pelo indivíduo, paralelamente ao papel do Estado, no sentido de que deve proporcionar alguns beneficios sociais que minimamente amparem a vida do doente como cidadão.

A estratégia do tratamento supervisionado, como uma das práticas que resguardam a perspectiva do indivíduo, ao mesmo tempo que protegem a coletividade, tem conquistado amplo terreno no reforço à adesão de doentes ao tratamento, assim como na diminuição da prevalência da resistência às drogas e recidiva da doença, configurando-se na atualidade como um padrão que recomenda-se ser reproduzido na assistência à saúde (BAYER e DUPUIS, 1996). Segundo MORSE (1996), o custo do tratamento de um doente com resistência multimedicamentosa seria de aproximadamente 200.000 dólares, montante que seria suficiente para fornecer terapêutica observada diretamente a cerca de 700 doentes.

Uma outra possibilidade que tem sido defendida por muitos investigadores para a sustentação da adesão refere-se ao emprego do tratamento intermitente, que reduziria o custo global do tratamento e a sua toxicidade. As primeiras experiências que fizeram uso dessa modalidade de tratamento ocorreram na década de 60 , tendo sido realizadas pelo Centro de Quimioterapia Antituberculosa de Madras, na Índia, empregando a estreptomicina e isoniazida, duas vezes por semana, por um ano. Em 1970, a União 
Internacional contra a Tuberculose divulgou os resultados que evidenciam a eficácia do esquema intermitente de tratamento (MINISTÉRIO DA SAÚDE, 1994b).

CASTELO FILHO (1993) faz referência ao primeiro estudo controlado conduzido pelo Conselho Britânico de Pesquisas Médicas, em Hong Kong, em 1977, o qual revelou que o uso de estreptomicina, isoniazida e pirazinamida, duas a três vezes por semana, durante nove meses, mostrava eficácia igual ao uso diário dessas drogas, atingindo uma taxa de cura de 94\%. Em 1979, o Programa de Tuberculose do Departamento de Saúde de Arkansas, EUA, evidenciou taxas de recidivas baixas, de $1,4 \%$, após tratamento utilizando rifampicina e isoniazida, diariamente durante o primeiro mês, seguindo-se o uso das mesmas drogas, duas vezes por semana por 8 meses. Outros estudos continuaram a ser desenvolvidos relatando o emprego de duas ou três drogas, por dois dias semanais, sendo que em 1991 foi realizado novo estudo em Hong Kong, defendendo o uso da terapêutica intermitente. Segundo o mesmo autor, mesmo sendo já empregado em praticamente todos os países da América Latina, com exceção da Nicarágua, o tratamento intermitente não foi adotado no Brasil, apesar de efetivo e menos custoso. Somente o Distrito Federal tem utilizado essa prática desde o início dos anos 80 , com resultados aparentemente animadores.

A VII Experiência Nacional de Quimioterapia da Tuberculose, que teve lugar no Brasil procedeu ao estudo de três esquemas intermitentes, administrados duas vezes por semana, evidenciando sucesso bacteriológico de $95 \%$, falência de $4 \%$ e recidiva de $4,8 \%$, taxas semelhantes àquelas obtidas com o uso diário das drogas (MINISTÉRIO DA SAÚDE, 1994b).

Conforme foi visto no percurso do presente estudo, a necessidade de tomar a medicação diariamente se coloca como mais um obstáculo a ser transposto por alguns doentes durante a realização do tratamento para a tuberculose. Tendo isso em vista, parece que a adoção do esquema intermitente seria uma opção a ser empregada com a finalidade de facilitar a adesão dos doentes ao tratamento, o que aponta para a necessidade de estudos sobre essa alternativa em nível nacional que levem em conta as especificidades epidemiológicas regionais. 
Através dos conteúdos das frases temáticas que explicitam as representações que têm os sujeitos a respeito do Programa de Controle da Tuberculose e, mais particularmente, da sua adesão ao tratamento, verificou-se que vários processos estão imbricados à consecução desse que é um dos maiores objetivos a serem alcançados pelo Programa. Verificou-se que, aparentemente não se trata de um resultado de um comportamento de âmbito individual. não cabendo portanto, analisar a questão somente contemplando a experiência individual do paciente, mas de verificar que ela se interarticula com os processos estruturais que constituem o arcabouço da sociedade, bem como com a forma pela qual se configura o acesso ao cuidado à saúde. Há assim, uma intermediação dinâmica entre a inserção social do individuo e seu agir/pensar, sendo que estes também sofrem as determinações da estrutura jurídico-político-ideológica que envolve a sociedade. Assim, a adesão está permeada pela forma como a pessoa ocupa seu lugar na sociedade, bem como pela forma como se organizam os serviços de saúde, particularmente no que se refere ao processo de produção dos serviços de saúde e aos processos de trabalho dos profissionais de saúde, além de dizer respeito à esfera na qual se desenvolve a vida do doente, incluindo-se aqui a relação com o trabalho e com as possibilidades de existência. Há sim uma esfera que diz respeito à dimensão mais singular, que se refere às relações com pessoas que com ele convivem e que de alguma maneira jogam papéis de relevância na condução do processo de tratamento.

Pôde-se depreender que da forma como estão se efetivando as práticas de saúde hoje, com o esfacelamento das unidades de saúde que constituem a rede pública de saúde, o que pode-se vislumbrar é a piora progressiva da qualidade da assistência, uma vez que aspectos que ainda revelam essa qualidade, são em geral produtos da resistência de trabalhadores frente ao desastre da desconstrução do sistema público de saúde. Dessa maneira. não se pode permitir a existência de programas de saúde que se constituem em instâncias administrativas de imposição de pacotes completos de normas universais, que desconsideram os problemas, os recursos disponiveis e, sobretudo, as diferenças em termos de necessidades dos grupos sociais. Ao contrário, os programas devem ser reavaliados no que se refere às questões de ordem administrativa e que, via de regra, contribuem para sua robustez e, ao mesmo tempo fragilidade, no que toca à eficiência. Nestes, inclui-se a necessidade de refuncionalizar o Programa de Controle da Tuberculose, no sentido que deve estar integrado às ações que tem em vista o adulto 
trabalhador, renovando as estratégias de intervenção segundo a ótica da determinação social do processo saúde-doença. De outra maneira, continuar-se-á a reproduzir ações que contribuem apenas para abordagens clínicas, centradas no biológico e que tomam o indivíduo apenas como um sistema que, quando muito, inclui aspectos de ordem psíquica.

NAGPAUL (1984) aponta que seria ingênuo pensar que um novo programa, uma organização distinta dos serviços de saúde, outra equipe de pessoas ou um aporte maior de financiamento e material pudessem conduzir à melhora da eficácia operativa e da situação global da tuberculose. $O$ pesquisador aponta que o problema reside na seleção das prioridades nacionais, na insuficiência dos planos, nas competências administrativas, além dos problemas por ele denominados de ordem "sociológica", operativa e de valoração, incluindo, evidentemente, a falta de recursos.

Ampliando-se essa leitura, GRANGE e FESTENSTEIN (1993) ressaltam que a questão da tuberculose será encaminhada para o seu equacionamento se forem apropriados os recursos para o estudo da natureza das micobactérias, mas também do suporte das ciências sociais, da antropologia, das ciências humanas, uma vez que é uma doença de caráter eminentemente social e que ressurge, carecendo de investigações que dêem conta de abordagens mais totalizadoras, que integrem a fisiopatologia da doença, a multirresistência às drogas, mas também o ser humano com tuberculose, portador de necessidades peculiares que não têm sido contempladas no âmbito da assistência à saúde.

Nesse sentido, coloca-se a necessidade do desenvolvimento de investigações que contribuam para o encaminhamento de soluções para a questão da tuberculose, além das que anteriormente foram apontadas, incluindo-se a avaliação da estratégia do tratamento supervisionado, bem como outras que contribuam para a definição da eficiência entre o tratamento continuado ou intermitente. Além disso, dado que a tuberculose é doença em que a determinação social é indubitavelmente presente, necessário se faz perceber que as mudanças do seu padrão epidemiológico se constituirão como resultado de intervenções profundas no acesso igualitário da coletividade aos bens sociais. 
De igual maneira, a transformação da assistência em saúde é necessária, afinal, conforme lembra MERHY (1996), é fundamental que o doente tenha garantia da abordagem de seus problemas de saúde, a partir de uma ótica nele centrada “... uma abordagem que considere o elemento mais chave, mais importante de todo o sistema de saúde é (...) o próprio usuário. De um modo óbvio, qualquer que fôsse o serviço de saúde, o mote principal para a sua organização tem que ser o cidadão, ou cidadãos, portador das necessidades/problemas de saúde". 
Gonclusões e Gonsiderações Finais 


\section{CONCLUSÕES E CONSIDERAÇÕES FINAIS}

A ressurgência da tuberculose no âmbito mundial, em decorrência da sua associação com a AIDS, da progressiva multirresistência às drogas, da crescente deterioração das condições de vida e de acesso à saúde de certos segmentos sociais, bem como as baixas taxas de adesão ao tratamento colocam em pauta o desafio de revisitar os princípios técnicos, éticos e legais das medidas de controle tradicionalmente utilizadas. Neste sentido, este estudo sobre a adesão de clientes ao Programa de Controle da Tuberculose busca contribuir para o preenchimento da lacuna na elucidação dos processos que levam as pessoas a seguirem o tratamento medicamentoso integralmente. As conclusões e considerações que aqui estão colocadas, referem-se à população estudada, ou seja, os ex-doentes matriculados em unidades básicas de saúde do Distrito Sanitário do Butantã.

A análise dos discursos dos ex-doentes à luz da Teoria das Necessidades e da Determinação Social do Processo Saúde-Doença revelou que a forma como as pessoas estão alocadas na sociedade, ou seja, sua inserção no processo de produção, que vai thes conferir um acesso diferenciado aos bens que satisfarão as suas necessidades, parece influenciar o modo como vivenciam a doença, bem como a adesão ao Programa de Controle da Tuberculose. Há uma relação entre o pensar do sujeito e a forma como a coletividade apreende a enfermidade, que é fruto da estruturação da sociedade e da forma como nela se relacionam os sujeitos sociais, tanto em termos da produção como da reprodução social. Assim, a relação das pessoas com o trabalho e com a vida vai imprimir certas maneiras de enfrentar a doença, que vão influir na adesão ao tratamento.

Assim, a análise dos depoimentos das pessoas que foram acometidas pela tuberculose permitiu verificar:

- que a tuberculose ainda é uma doença impregnada pelo preconceito, cuja causa está permeada pela metáfora da indisciplina daqueles por ela acometidos.

- a noção de causa da doença está assentada fundamentalmente no plano biológico e na fatorialidade 
- a assistência está representada para o doente, sobretudo pela impessoalidade e pela atuação do profissional médico que, em geral, exerce uma prática centrada no plano biológico, tomando a doença como um efeito.

- a busca da assistência à saúde está entremeada por uma série de barreiras a serem transpostas pelo doente, as quais referem-se às possibilidades do acesso à saúde e à sua mobilidade no processo de produção e de reprodução social para o atendimento às necessidades de saúde.

- a Unidade de Saúde tem se apresentado somente como um locus onde se dá o atendimento e, via de regra, há um comportamento conformista do doente em relação à assistência, que o faz aceitá-la sem a alternativa de propor mudanças para que se efetivem respostas às suas necessidades.

- a concepção da adesão ao tratamento associa-se à forma como a pessoa compreende a enfermidade.

- as representações em relação à doença, bem como o comportamento do doente parecem estar intimamente articulados à forma como a sociedade impõe certas atitudes, regras ou normas sobre a tuberculose, as quais se interrelacionam com a história pela qual o ser humano foi apreendendo a doença e foram se estabelecendo ações e políticas para o seu enfrentamento.

- como produto de suas relações com o trabalho e com a vida, os sujeitos portadores da doença, que via de regra são aqueles que estão inseridos de forma precária no processo de produção social e, especificamente os que integraram o presente estudo, vão lidar com a enfermidade segundo as potencialidades ou dificuldades que tem com a vida e com o trabalho, estabelecendo projetos de vida, nos quais a superação da doença é um objetivo a ser alcançado, razão pela qual fundamentalmente a adesão ao tratamento se concretiza. 
- a adesão ao tratamento está intrinsecamente associada à forma como se produz a assistência à saúde, ou seja, depende da organização da assistência e da forma como se realiza o trabalho na unidade de saúde.

- o atendimento às necessidades das pessoas pela unidade de saúde constitui o alicerce essencial que vai determinar a efetivação do engajamento no tratamento: a assistência que contempla as necessidades dos sujeitos, que acolhe não somente as queixas de ordem biológica, mas que possibilita um espaço de interlocução entre o trabalhador de saúde e o doente, para que sejam abordadas as necessidades que emanam da sua forma de vida e trabalho, pode atuar como um elemento crítico na adesão ao tratamento.

- o respaldo que o sujeito enfermo pode dispor no âmbito familiar, do trabalho e também no espaço da assistência à saúde atua como suporte para a adesão ao tratamento, na medida em que permite a constituição de espaços para compartilhar e o enfrentar o processo saúde-doença, com os obstáculos que este pode apresentar.

A Teoria da Determinação Social do Processo Saúde-Doença explica a manifestação da tuberculose como uma totalidade-parte da vida cotidiana que incorpora a singularidade do individuo doente, sendo esta subjacente à sua posição na sociedade e ao modo como a sociedade se estrutura. Esse marco de referência orientou o entendimento de que a adesão ao tratamento revelou-se como uma categoria diretamente articulada à cotidianidade, enquanto espaço de constituição, produção e reprodução do ser social, conforme explicita a Teoria das Necessidades.

Depreende-se assim, que a adesão ao tratamento configura-se como uma questão que transcende os limites relativos às atitudes ou comportamentos dos indivíduos, conforme muito se propala na literatura. Dada a magnitude com que a doença vem se apresentando, deve ser enfocada pelas diferentes instâncias que integram o Sistema Nacional de Saúde brasileiro. Enquanto esse cuidado não for tomado, ou seja, enquanto a tuberculose não for enfrentada como um produto eminentemente social e que se relaciona ao acesso ao trabalho e à qualidade de vida e que, portanto, carece de um olhar 
especial no que toca à organização dos serviços de saúde, à disponibilidade de medicação e de um suporte de qualidade em termos de recursos humanos e financeiros, é evidente que as ações que são pautadas somente no nível do indivíduo não surtirão o impacto desejado. Evidentemente que aqui se está fazendo referência ao fato de que a vontade política para resolver a questão da tuberculose deve prevalecer e isso certamente está articulado a um pensar distinto sobre a saúde. Trata-se de fazer jus ao conceito ampliado de saúde, conforme consta na Constituição Brasileira e isso envolve eqüidade no acesso à saúde, bem como traz à tona o papel que o Estado deve ter em relação à saúde. A concretização dos princípios que regem o Sistema Único de Saúde do país deve conduzir à reorientação do processo de produção da saúde e, portanto, à reorganização dos serviços. Nesse cenário devem estar contempladas também estratégias de promoção à saúde, entendida esta como a capacitação do coletivo quanto à transformação da sua qualidade de vida e saúde, incluindo a sua participação no controle desse processo. A partir daí é que se visualiza o estabelecimento das políticas públicas para o enfrentamento da doença, cujo curso e incidência dependem criticamente do interesse e do compromisso do Estado para com a coletividade.

Um ponto que merece destaque é o fato de que a mudança das instituições de saúde em termos de organização e financiamento por si só não produz impacto sobre a adesão ao Programa de Controle da Tuberculose, uma vez que é fundamental alterar o modo como os trabalhadores de saúde relacionam-se com o doente e, mais especificamente, com a vida e o sofrimento dos indivíduos e da coletividade. Toma-se pois como tarefa urgente, que nos processos de trabalho que se desenvolvem nos serviços de saúde sejam contempladas as questões que dizem respeito ao modo como o usuário representa as suas necessidades de saúde. Esse universo, se operacionalizado no conjunto de conhecimentos sobre saúde - entre eles, os saberes que a Clínica e a Epidemiologia já tem desenvolvido - promoverá a realização de intervenções realmente eficazes, sem perder de vista a dimensão na qual a abordagem individual qualificada permitirá o entendimento das necessidades de saúde para que se projetem ações que transformem os perfis epidemiológicos. Essa mudança de visão conduz a uma reorientação da prestação da assistência, baseada sobretudo nas necessidades do indivíduo e da coletividade, segundo as carências de ordem biológica e social, que resultam das formas de inserção no trabalho e dos modos de vida. 
A adesão, enquanto categoria analisada no presente estudo está diretamente articulada à cotidianidade e esta não se desloca do espaço da reprodução social. Assim, o processo de produção da saúde deve incorporar a dimensão da adesão enquanto elemento que passa a incorporar o cotidiano do sujeito doente e como tal deve ser contemplada nas intervenções em saúde. Dessa forma, é preciso que os trabalhadores de saúde se engajem na construção de um nova modalidade de assistência à saúde que contemple a sua aproximação ao cotidiano dos doentes. Essa nova modalidade de assistência deve ter implícita a singularidade do doente frente à sua posição na sociedade, através de intervenções que busquem a superação da vulnerabilidade biológica e social.

Trata-se pois de transformar as práticas que se desenvolvem junto aos doentes, mas também de dar impulso às intervenções junto à coletividade. Dessa forma, as práticas de ordem coercitiva não devem prevalecer para a garantia da adesão. Cada vez mais tem estado em pauta a questão legal e ética quando se procede à leitura da doença a partir da noção da proteção do indivíduo e do coletivo, questionando-se os limites dos direitos individuais, bem como os princípios de autonomia e auto-determinação frente aos direitos da coletividade. Sob a máscara da defesa da liberdade do coletivo, propostas coercitivas são impostas aos indivíduos doentes, sem que de fato sejam efetivadas medidas que causem impacto na redução da incidência da doença.

Assim, evidenciar os pontos de estrangulamento que determinam comportamentos de não adesão deve se constituir, em conjunto com medidas que diminuam as carências em termos de acesso àqueles que estão à margem da sociedade, na tônica do trabalho em saúde, para que o tratamento medicamentoso não se torne mais um fardo a carregar na vida. Há, portanto, necessidade de um programa dinâmico, eficiente, estruturado e funcionante de controle da doença, articulado à atenção integral ao adulto-trabalhador.

A Teoria de Intervenção Práxica da Enfermagem em Saúde Coletiva, proposta por EGRY (1996), a qual consiste na "sistematização dinâmica de captar e interpretar um fenômeno articulado aos processos de produção e reprodução social referentes à saúde e doença de uma dada coletividade, no marco de sua conjuntura e estrutura, dentro de um contexto social historicamente determinado: de intervir nessa realidade e, 
nessa intervenção, prosseguir reinterpretando a realidade para novamente nela interpor instrumentos de intervenção", pode constituir-se em uma alternativa para a transformação do processo de produção à saúde, na medida em que possibilita a visualização mais ampliada da saúde-doença e pode responder a aspectos importantes que sistematicamente não têm sido contemplados pelos vários motivos já discutidos nesta investigação.

Essa teoria, aliada à vulnerabilidade, conceito tomado emprestado de AYRES (1997) e modificado para a questão da adesão, tendo-se esta como a apreensão de comportamentos que podem levar ao abandono do tratamento, os quais “... não são consciência imediata da vontade dos indivíduos, mas relacionam-se ao grau de consciência que têm dos possíveis danos decorrentes de tais comportamentos e ao poder de transformação efetiva de comportamentos a partir dessa consciência", poderia proporcionar, no âmbito da Saúde Coletiva uma abordagem diferenciada, constituindo-se como um dos caminhos para o controle da tuberculose em nosso meio. Afinal conforme o próprio autor refere: “....a tarefa conceitual e técnica da saúde pública, tal como parece recolocar-se nesse fim de século: identificar, compreender e (re)socializar as motivações e movimentos microssociais configurados pela experiência compartilhada e cotidiana da saúde e do adoecimento".

Nessa linha. as intervenções que devem integrar o controle da tuberculose dar-seiam basicamente através de dois eixos articulados e interdependentes. Um, que se refere à singularidade do doente e outro que se refere às ações junto ao coletivo. $\mathrm{O}$ primeiro deve enfocar ações que contemplem desde a des-estigmatização da doença, bem como o trabalho educativo de disponibilização de informações para o reconhecimento da enfermidade, além da efetivação da vigilância epidemiológica que transcenda os muros institucionais, adquirindo o caráter de vigilância à saúde, até a incorporação da estratégia do tratamento supervisionado para determinados grupos, especialmente aqueles que se apresentem como potenciais para o abandono, em decorrência da precária inserção na sociedade, ou aqueles que apresentem dificuldades em relação à tolerância medicamentosa, dentre outros. Conforme dito anteriormente, a organização do trabalho na unidade de saúde deve incorporar o conceito de acessibilidade e realizar a transdisciplinaridade, com o sentido de valer-se dos distintos campos de conhecimentos e 
de práticas dos diferentes trabalhadores da saúde com vistas a decodificar mais apropriadamente as carências apresentadas pelos doentes e a compartilhar as singularidades e as vivências. Dessa forma, a unidade de saúde deixaria de ser um espaço institucional para constituir-se como um espaço de práticas sociais.

As ações junto ao coletivo dar-se-iam na perspectiva da apreensão das necessidades dos sujeitos sociais e a instituição de práticas que contribuam para a sua emancipação como cidadãos. Privilegiar-se-iam, portanto, mais uma vez, o trabalho de cunho educativo, que diz respeito à disponibilização de instrumentos e de meios para que o sujeito e o coletivo possam entender a saúde-doença como processo determinado socialmente para superar os momentos de vulnerabilidade. Para tanto, a disponibilização de informações não só no âmbito da produção da saúde, mas em instituições que trabalhem com o social, como também o vínculo com organizações que congreguem grupos sociais são fundamentais quando se propõe uma nova modalidade de assistência. Simultaneamente, como protagonistas do processo de produção da saúde, os trabalhadores da saúde tem um espaço privilegiado e que deve ser ocupado no sentido de contra-argumentar sobre a situação de saúde. Nessa perspectiva, deve-se proceder ao questionamento sobre os recursos que vêm sendo dispendidos para o financiamento para as ações de controle da doença, em termos de insumos para a prática da assistência, como para a investigação, uma vez que a tuberculose não tem tido a mesma importância que o lobby que se tem verificado em relação a outras enfermidades.

Portanto, diante de um cenário de rupturas históricas é necessário que seja construída uma práxis crítica de intervenção, que permita proceder à interpretação do universo das necessidades de saúde, uma vez que integram a cotidianidade. Trata-se, portanto, de admitir a dinâmica complexa da produção da saúde, com uma visão ampla que inclua os aspectos relacionados ao espectro que, de forma geral, os trabalhadores da saúde têm evitado tocar, a dimensão do sofrimento humano e da desproteção da vida, que sem dúvida geram demandas potenciais e reais por ações de saúde. Desta forma, não se estará anulando a especificidade e a individualidade dos sujeitos, mas articulando as questões que emergem do eixo singular com o outro, que diz respeito às necessidades e particularidades dos grupos sociais e da coletividade. 
Referências Bibliográficas 


\section{REFERÊNCIAS BIBLIOGRÁFICAS}

ADDINGTON, W.W. Patient compliance: the most serious remaining problem in the control of tuberculosis in the United States. Chest., 76 (suppl.): 741-3, 1979.

ADMINISTRAÇÃO REGIONAL DO BUTANTÃ. Equipe intersecretarial de planejamento outubro/novembro de 1991. São Paulo, 1991.

ANDERSON, W.T. \& HELM, D.T. The physician-patient encounter: a process of reality negotiation. In: Jaco, G., ed.. Patients, physicians and ilness. New York, The Free Press, 1979. p. 259-71.

ANDRÉ, M.E.D.A. de. Texto, contexto e significados: algumas questões na análise de dados qualitativos. Cad. Pesq. (45): 66-71, 1983.

ANNAS, G.J. Control of tuberculosis - the law and the public's health. N. Engl. J. Med., 328: 585-8, 1993.

ANUÁRIO ESTATÍSTICO DO BRASIL: 1996. Rio de Janeiro. 56: 6-57, 1996.

ARANTES, G.R. et al. Monitorização das ações anti-tuberculose: implantação de uma sistemática experimental em São Paulo - Brasil. Bol. Pneumol. Sanit. V.3, N.2, P. 10-25, 1995.

AYRES, J.R. Vulnerabilidade e AIDS: para uma resposta social à epidemia. Bol. Epidem. Prog. DST/AIDS., 3: 2-4, 1997.

BAKHTIN, M. Marxismo e filosofia da linguagem. São Paulo, Hucitec, 1986.

BALINT, M. The doctor, his patient and the illness. New York, International University Press, 1957.

BARNES, P.F. et al. Tuberculosis in patients with human immunodeficiency virus infection. N. Engl. J. Med., 324: 1644-50, 1991.

BARNHOORN, F. \& ADRIAANSE, H. In search of factors responsible for noncompliance among tuberculosis patients in Wardha District, Índia. Soc.Sci.Med., 34: 291-306, 1992.

BARREIRA, I. de A. A enfermeira Ana-Néri no "País do Futuro", a aventura da luta contra a tuberculose. Rio de Janeiro, 1992. [Tese de Doutoramento - Escola de Enfermagem Anna Nery da UFRJ].

BATES, B. Bargaining for life: a social history of tuberculosis, 1876-1938. Philadelphia, University of Pennsylvania Press, 1992.

BAYER, R. et al. The dual epidemics of tuberculosis and AIDS: ethical and policy issues in screening and treatment. Am. J. Public Health., 85 (5): 649-54, 1993. 
BAYER, R. e DUPUIS, L.J. Ethical and legal issues in tuberculosis control. In: Rom, W.N. \& Garay, S. Tuberculosis. New York, Little, Brown and Company, 1996. p. 965-72.

BECKER, M.H. et al. Patient perceptions and compliance: recent studies of the Health Belief Model. In: HAYNES, R. B. et al. Compliance in health care. Baltimore. The Johns Hopkins University Press, 1989. p.78-109.

BELLUOMINI, M. \& TAGUSAWA, H.K. Sequência do tratamento de curta duração da tuberculose pulmonar em unidades sanitárias do Vale do Paraíba, 1980-1981, São Paulo, Brasil. Rev. Saúde Pública, 18: 466-75, 1984.

BERLINGUER, G. A doença. São Paulo, Hucitec/Cebes, 1980.

BERTOLLI FILHO, C. História social da tuberculose e do tuberculoso: 1900-1950. São Paulo, 1993. [Tese de Doutoramento - Faculdade de Filosofia, Letras e Ciências Humanas da USP].

BERTOLOZZI, M.R. Pacientes com tuberculose pulmonar no Município de Taboão da Serra: perfil e representações sobre a assistência prestada nas unidades básicas de saúde. São Paulo, 1991. [Dissertação de Mestrado - Facudade de Saúde Pública da USP].

BETTELHEIM, C. A problemática do "subdesenvolvimento". In: Pereira, L., org. Subsedenvolvimento e desenvolvimento. 3.ed. Rio de Janeiro, Zahar, 1976, p.3-78.

BICICA, V. et al. The attitude of pulmonary tuberculosis patients towards treatment, a factor in the efficacy of chemotherapy. Pneumoftzialogia, 40 (3): 48-51, 1991.

BOERDIEU, P. Squisse dúne théorie de la pratique. Paris, Librairie Droz, 1972.

BRANDLI, O. et al. Results of short-term tuberculosis therapy with isoniazid, rifampicin and pirazinamide. Schweiz - Med - Wochenschr., 123 (25): 1300-6, 1993.

BRASIL. Leis, etc. Lei Orgânica da Saúde, lei nº 8080 de 19 de setembro de 1990. Saúde em Debate., 30: 15-20, 1992.

BRAUSCH, L.M. \& BASS, J.B. The treatment of tuberculosis. Med. Clin. North Am. 77: $1277-88,1993$.

BREILH, J. \& GRANDA, E. Investigação da saúde na sociedade: guia pedagógico sobre um novo enfoque do método epidemiológico. São Paulo, Instituto de Saúde, 1986.

BREILH, J. Nuevos conceptos y técnicas de investigación: guía pedagógica para un taller de metodología. Quito, CEAS, 1995.

BRUDNEY, K. \& DOBKIN, J. A tale of two cities: tuberculosis control in Nicaragua and New York City. Semin. Resp. Infect., 6: 261-72, 1991 a. 
BRUDNEY, K. \& DOBKIN, J. Resurgent tuberculosis in New York City: human immunodeficiency virus, homelessness, and the decline of the tuberculosis control program. Amer. Rev. Respir. Dis., 144: 745-49, 1991 b.

BUCHILLET, D. Tuberculose, busca de assistência médica e observância terapêutica na Amazônia brasileira. Saúde: França-flash. 11: 1-8, 1997.

CAMPOS, G.W. de S. Modelos de atenção em saúde pública: um modo mutante de fazer saúde. Saúde em Debate., 37: 16-9, 1992.

CANTWELL, M.F.et al. Epidemiology of tuberculosis in the United States, 1985 through 1992. JAMA., 272: 535-9, 1994.

CAR, M.R. Da aparência à essência: a práxis assistencial dos trabalhadores da Liga de Hipertensão Arterial. São Paulo, 1993. [Tese de Doutorado - Escola de Enfermagem da USP].

CASTELO FILHO, A. Tratamento intermitente para tuberculose pulmonar: oportunidade de uso no Brasil. Pneumol., 19: 50-1, 1993.

CENTERS FOR DISEASE CONTROL. A strategic plan for the elimination of tuberculosis in the United States. MMWR Morb. Mortal. Wkly Rep., 38, (Suppl. 3): $1-25,1989$.

CENTERS FOR DISEASE CONTROL. Nosocomial transmission of multidrug-resistant tuberculosis to health-care workers and HIV-infected patients in an urban hospital Florida. MMWR Morb. Mortal. Wkly Rep., 39: 718-22, 1990.

CENTERS FOR DISEASE CONTROL. Initial therapy for tuberculosis in the era of multidrug resistance: recommendations of the advisory council for the elimination of tuberculosis. MMWR Morb. Mortal. Wkly Rep., 42: RR-7, 1993a.

CENTERS FOR DISEASE CONTROL . Approaches to improving adherence to tuberculosis therapy-South Caroline and New York, 1986-1991. MMWR Morb. Mortal. Wkly Rev., 42 (5): 74-5, 1993 b.

CENTRO DE VIGILÂNCIA EPIDEMIOLÓGICA (CVE). São Paulo (Estado). Divisão de Tuberculose e outras Pneumopatias. Tuberculose: uma emergência mundial. 1995.

CENTRO NACIONAL DE EPIDEMIOLOGIA (CENEPI). Ministério da Saúde. Fundação Nacional de Saúde. Inf. Epidemiol. SUS, Brasilia, 4: 161, 1992.

CENTRO NACIONAL DE EPIDEMIOLOGIA (CENEPI). Ministério da Saúde. Fundação Nacional de Saúde. Inf. Epidemiol. SUS, Brasilia, 3: 116, 1993.

CHAMMÉ, S.J. Educação para a doença. Saúde em Debate, 44: 32-4, 1994. 
CHAULET, P. Cumplimiento de quimioterapia de la tuberculosis: responsabilidades del Ministerio de Salud y de los medicos. Bol. Unión Intern. Contra Tuberc. Enferm. Respir, 66 (Supl):35-7, 1990/1991.

CHMELEV, N. A. \& ALYABINA, M.G. Collective studies from the whole of the Soviet Union on controlled chemotherapy of pulmonary tuberculosis. Bull. Int. Union Tuberc, 47: 22-9, 1972.

CHUAH, S.Y. Factors associated with poor patient compliance with antituberculosis therapy in Northwest Perak, Malaysia. Tubercle, 72: 261-4, 1991.

CORPE, R. Rifampicin in original treatment of pulmonary tuberculosis: a United States public health service cooperative therapy trial. Bull. Int. Union Tuberc., 47: 41-7, 1972.

CORTEJOSO, L. El dolor en la vida y en el arte. Barcelona, Iberia, Joaquim Gil Ed. 1943.

COSTA, J.D. et al. Controle epidemiológico da tuberculose na cidade de Pelotas, R.S.: adesão ao tratamento. In: Congresso Brasileiro de Saúde Coletiva, $5^{\circ}$ Congresso Paulista de Saúde Pública, $5^{\circ}$, Águas de Lindóia, 1997. Livro de resumos. São Paulo, Associação Brasileira de Pós-Graduação em Saúde Coletiva/ Associação Paulista de Saúde Pública/ Faculdade de Saúde Pública da Universidade de São Paulo, 1997. p. 71.

CRAWFORD, R. Healthism and the medicalization of everyday life. Int. J. Health Serv., 10: 365-89, 1980.

CRESPO, R. et al. Difficulties in carrying out the treatment as seen by the tuberculosis patient. Aten. Primaria, 9: 206-2, 1992.

DEHEINZELIN, D. et al. Fatores preditivos de abandono de tratamento por pacientes com tuberculose. Rev. Hosp. Clín. Fac. Med. S. Paulo, 51: 131-5, 1996.

DIXON, W.M. et al. Compliance was assessed among tuberculosis outpatients for whom PAS have been prescribed. Lancet, 2: 871-72, 1957.

DOLIN, P.J. et al. Global tuberculosis incidence and mortality during 1990-2000. Bull. World Health Org., 72: 213-20, 1994.

DUBRA, F. Controlled therapeutic trial with the combination rifampicin-isoniazid given for 6 months in previously untreated patients with pulmonary tuberculosis. Bull. Int. Union Tuberc., 47: 37-40, 1972.

EGRY, E.Y. Saúde coletiva: construindo um novo método em enfermagem. São Paulo, Ícone. 1996.

FACCHINI, L. A. Por que a doença? A influência causal e os marcos teóricos de análise. In: Uma cosmovisão: a vida, o homem e o trabalho. s.n.t. p.33-5. 
FARMER, P. et al. Tuberculosis, poverty, and "compliance": lessons from rural Haiti. Semin. Respir. Infect., 6: 254-60, 1991.

FERNANDES, F. O problema do método na explicação sociológica. São Paulo, Pioneira, 1971.

FERREIRA, A. B.de H. org. Novo dicionário da língua portuguesa. 2.ed. Rio de Janeiro, Nova Fronteira, 1986. p.45.

FERRER, X. et al. Compliance with tuberculosis treatment in adults in Santiago, Chile. Bol. Oficina Sanit. Panam., 111: 423-31, 1991.

FIORIN, J.L. Linguagem e ideologia. São Paulo, Ática, 1988.

FIORIN, J.L. Elementos de análise do discurso. São Paulo, EDUSP, 1989. 93p.

FIORIN, J.L.; SAVIOLI, F.P. Para entender o texto: leitura e redação. São Paulo, Ática, 1991.

FOX, W. Self-administration of medicaments: a review of published work and a study of the problems. Bull. Int. Union Tuberc., 32: 307-31, 1962.

FOX, W. General considerations in the choice and management of regimens of chemotherapy for pulmonary tuberculosis. Bull. Int. Union Tuberc. 47: 49, 1972.

FOX, W. \& MITCHISON, D.A . Short-course chemotherapy for pulmonary tuberculosis. Am. Rev. Respir. Dis., 111: 325-53, 1975.

FOUCAULT, M. O nascimento da clínica. Rio de Janeiro, Forense Universitária, 1977.

FRENK. J. El concepto y la medición de acesibilidad. Salud Publica Mex. 1985.

FRIEDMAN, et al. Tuberculosis screening in alcoholics and drug addicts. Am. Rev. Resp. Dis., 136: 1188-92, 1987.

GALLO, E. et al. Razão e planejamento: reflexões sobre política, estratégia e liberdade. São Paulo, Hucitec, Rio de Janeiro, Abrasco, 1995. p. 37-105.

GEOFFREY, R. Epidemiological model and cost-effectiveness analysis of tuberculosis treatment programmes in Indonesia. Int. J. Epidemiol., 18: 174-9, 1989.

GERHARDT, G. \& RIBEIRO, S.N. Eficiência do tratamento da tuberculose no Brasil. Inf. Epidemiol. SUS., Brasilia, (6): 95-8, 1995.

GOFFMAN, E. Estigma: notas sobre a manipulação da identidade deteriorada. Rio de Janeiro, Zahar, 1982. 
GORDIS, S.L. Conceptual and methodological problems in measuring patient compliance. In: Haynes, B. et al. Compliance in health care. Baltimore, Johns Hopkins University Press, 1989.p. 23-45.

GRAMSCI, A. Concepção dialética da história. 9.ed. Rio de Janeiro, Civilização Brasileira, 1991.

GRANGE, J.M.; FESTENTEIN, F. The human dimension of tuberculosis control. Tubercle Lung Dis., 74: 219-22, 1993.

GRIGG, E.R.N. The arcana of tuberculosis: with a brief epidemiologic history of the disease in the U.S.A. Am. Rev. Tuberc. Pulm. Dis., 78 (2): 151-72, 1958.

GUARESCHI, P. "Sem dinheiro não há salvação": ancorando o bem e o mal entre os neopentecostais. In: Jovchelovitch, S. \& Guareschi, P. , org. Textos em representações sociais. Petrópolis, Vozes, 1994. p. 191-228.

GUPTA, P. R. et al. Influence of prior information of drug toxicity on patient compliance. J. Assoc. Physicians Índia, 40: 181-3, 1992.

HAAS, F.; HAAS, S.S. The origins of Mycobacterium tuberculosis and the notion of its contagiousness. In: Rom, W.N. \& Garay, S. Tuberculosis. New York, Little, Brow and Company, 1996. p. 3-19.

HARDY, E. Palabras inaugurales. In: Kornblit, A. Ciencias sociales y medicina: la salud en Latino America. Buenos Aires, Instituto de Investigaciones de la Facultad de Ciencias Sociales de la Universidade de Buenos Aires, 1994. p. 11-2.

HAWES, J.B.Talks on tuberculosis with patients and their friends. Boston, Houghton Mifflin Company, 1931.

HAYNES, R.B. Determinants of compliance: the disease and the mechanisms of treatment. In: Haynes, R. B. et al. Compliance in health care. Baltimore, Johns Hopkins University Press, 1989a. p. 49-62.

HAYNES, R.B. et al. Compliance in health care. Baltimore, Johns Hopkins University Press. $1989 \mathrm{~b}$.

HELLER. A. O cotidiano e a história. 4.ed. São Paulo, Paz e Terra. 1970.

HELLER. A. Teoría de los sentimientos. 3.ed. Barcelona, Fontamara, 1985.

HELLER, A. Teoría de las necesidades en Marx. Barcelona, Península, 1986.

HELLER, A. Sociología de la vida cotidiana. Barcelona, Península.1991.

HERZLICH, C. A problemática da representação social e sua utilidade no campo da doença. Physis: Rev. Saúde Coletiva., 1 (2): 23-34, 1991. 
HILL, J.P. \& RAMACHANDRAN, G. A simple scheme to improve compliance in patients taking tuberculosis medication. Trop. Doct., 22: 161-3, 1992.

HIJJAR, M. A. Vencer a tuberculose, agora e para sempre. Pneumol., 19 (1): 6-7, 1993.

HIV associated tuberculosis: a barometer for wider tuberculosis control and prevention. [Editorial]. BMJ, 314: 1847, 1997.

HOLM, J. La lucha antituberculosa en el mundo en desarollo: hay que cambiar de rumbo. Foro Mund. Salud, 5: 119-37, 1984.

HUDELSON, P. Gender diferentials in tuberculosis: the role of socio-economic and cultural factors. Tubercle Lung Dis. 77: 391-400, 1996.

HULKA, B.S. Patient-clinician interactions and compliance. In: Haynes, R. B. et al. Compliance in health care. Baltimore, Johns Hopkins University Press, 1989. p. 63-77.

HUSSAIN, S.F. et al. Audit of a tuberculosis contact tracing clinic. BMJ, 304: 1213-5, 1992.

ISEMAN, M.D. \& MADSEN, L.A. Drug-resistant tuberculosis. Clin. Chest Med., 10: 341-53, 1989.

ISEMAN, M.D. et al. Directly observed treatment of tuberculosis. [Letter]. N. Engl. J. Med., 329: 136, 1993.

JOB, J.R.P.P. et al. Informações que antecederam o diagnóstico de tuberculose pulmonar e tempo decorrido até o início do tratamento em pacientes matriculados em centro de saúde, São Paulo (Brasil). Rev. Saúde Públ., 20 (1): 21-5, 1986.

JODELET, D. La representación social: fenómenos, concepto y teoría. In: Moscovici, S., ed. Psicologia social. Madrid, Paidós, 1986. p.469-94.

JOHNSTON, R.F. \& WILDRICK, K.H. "State of the art" review: the impact of chemotherapy on the care of patients with tuberculosis. Am. Rev. Resp. Dis., 109: 636-64, 1974.

JOVCHELOVITCH, S. Vivendo a vida com os outros: intersubjetividade, espaço público e representações sociais. In: Jovchelovitch, S. \& Guareschi, P. Textos em representações sociais. Rio de Janeiro, Vozes, 1994. p.63-85.

KANTORSKI, L.P. As transformações no mundo do trabalho e a questão da saúde algumas reflexões preliminares. Rev. Lat. Am. Enferm., 5 (2): 5-15, 1997.

KENT, P.W. et al. The therapy of pulmonary tuberculosis in Kenya: a comparison of the results achieved in a controlled clinical trials with those achieved by the routine treatment services. Tubercle, 51:24. 1970. 
KLEEBERG, H.H. Falta de cumplimiento y abandono: lecciones obtenidas de los ensayos terapéuticos. Bol.Unión Int.Tuberc., 6: 103, 1986.

KOCHI, A. The global tuberculosis situation and the new control strategy of the World Health Organization. Tubercle, 72: 1-6, 1991.

KUMARESAN, J.A. \& MAGANU, E.T. Case holding in patients with tuberculosis in Botswana. BMJ, 305: 340-1, 1992.

LACERDA, R.A. et al. A face iatrogênica do hospital: as demandas para o controle das infecções hospitalares. São Paulo, Atheneu, 1996.

LANE, S.T.M. Linguagem, pensamento e representações sociais. In: Lane, S.T.M. \& Codo, W. Psicologia social: homem em movimento. 2.ed. São Paulo, Brasiliense, 1985.p.32-9.

LEFÉVRE, F. O medicamento como mercadoria simbólica. São Paulo, Cortez, 1991.

LEOPARDI, M.T. Necessidades de saúde e cidadania. Rev. Bras. Enferm. , 1 (1): 54 $73,1992$.

LERNER, B.H. New York City's tuberculosis control efforts: the historical limitations of the "war on consumption". Am. J. Public Health, 83: 758-66, 1993.

LITTLE, M. Humane medicine. Cambridge, Cambridge University Press, 1995.

LOYOLA, M.A. Médicos e curandeiros: conflito social e saúde. São Paulo, DIFEL, 1984.

MANDÚ, E.N.T. Saúde no olhar de mulheres: afirmação e negação do saber e prática dominantes no campo médico. Ribeirão Preto, 1995. [Dissertação de Mestrado Escola de Enfermagem de Ribeirão Preto, USP].

MARTINY, P. et al. Decentralization of the tuberculosis campaign and its follow-up in the Dosso Department (Niger). Ann. Soc. Belg. Med. Trop., 72: 29-36, 1992.

MARX, K. Para a crítica da economia política. São Paulo, Abril Cultural, 1982.

MARX, K. \& ENGELS, F. Ideologia alemã. São Paulo, Hucitec, 1984.

McINTOSH, J. Processes of communication, information seeking and control associated with cancer. Soc. Sci. Med., 8, 1974.

MENDES-GONÇALVES, R.B. Medicina e história: raizes sociais do trabalho médico. São Paulo, 1979. [Dissertação de Mestrado - Faculdade de Medicina da USP].

MENDES-GONÇALVES, R.B. Práticas de saúde: processo de trabalho e necessidades. Cad. Cefor, 1992. 


\section{MENDES-GONÇALVES, R.B. Tecnologia e organização social das práticas de} saúde: características tecnológicas de processo de trabalho na rede estadual de centros de saúde de São Paulo. São Paulo, Hucitec, Rio de Janeiro, Abrasco, 1994.

MENDES-GONÇALVES, R. B. Seres humanos e práticas de saúde: comentários sobre "razão e planejamento". In: Gallo, E. et al. Razão e planejamento: reflexões sobre política, estratégia e liberdade. São Paulo, Hucitec, Rio de Janeiro, Abrasco, 1995. p. 13-36.

MENZIES, R et al. Factors associated with compliance in treatment of tuberculosis. Tuberc. Lung. Dis., 74: 32-7, 1993.

MERHY, E. E. Planejamento como tecnologia de gestão: tendências e debates do planejamento em saúde no Brasil. In: Gallo, E. et al. Razão e planejamento: reflexões sobre política, estratégia e liberdade. São Paulo, Hucitec, Rio de Janeiro, Abrasco, p. 117-148, 1995.

MERHY, E.E. Agir em saúde: micropolítica do trabalho vivo. Campinas, UNICAMP, 1996.

MILLER, B. Preventive therapy for tuberculosis. Med. Clin. North Am., 77:1263-75, 1993.

MINAYO, M.C.de S. Os desafios do conhecimento: pesquisa qualitativa em saúde. São Paulo, Hucitec, Rio de Janeiro, Abrasco, 1992.

MINAYO, M.C. de S. O conceito de representações sociais dentro da sociologia clássica. In: Jovchelovitch, S. \& Guareschi , P., org. Textos em representações sociais. Petrópolis, Vozes, 1994. p.87-111.

MINISTÉRIO DA SAÚDE. Divisão Nacional de Pneumologia Sanitária. Campanha Nacional de Controle da Tuberculose. Avaliação das atividades de controle da tuberculose realizadas no Brasil em 1987. Bol.Campanha Contra Tuberc., 2 (2): 58-102, 1988a.

MINISTÉRIO DA SAÚDE. Serviço Nacional de Pneumologia Sanitária. Divisão Nacional de Pneumologia Sanitária. Manual de normas para o programa da tuberculose. 3.ed. Brasilia, Centro de Documentação do Ministério da Saúde. 1988 b.

MINISTÉRIO DA SAÚDE. Reunião de avaliação operacional e epidemiológica do Programa Nacional de Controle da Tuberculose na década de 80. Brasília, 1992.

MINISTÉRIO DA SAÚDE. Fundação Nacional de Saúde. Segundo informe técnico sobre a vacinação/revacinação BCG. Brasília, Fundação Nacional de Saúde, 1994a. 
MINISTÉRIO DA SAÚDE. Secretaria Nacional de Programas Especiais de Saúde. Divisão de Pneumologia Sanitária. Campanha Nacional contra a Tuberculose. Controle da tuberculose: uma proposta de integração ensino-serviço. 4.ed., Brasilia, CNCT/NUTES, 1994b.

MINISTÉRIO DA SAÚDE. Fundação Oswaldo Cruz. Informação Educação e Comunicação. Promoção da saúde: Carta de Otawa, Declaração de Adelaide, Declaração de Sundsvall, Declaração de Bogotá. Brasilia, Ministério da Saúde, 1996a.

MINISTÉRIO DA SAUUDE. Fundação Nacional de Saúde. Centro Nacional de Epidemiologia. Coordenação Nacional de Pneumologia Sanitária. Diretrizes do plano emergencial para o controle da tuberculose no Brasil 1996/1998. Brasília, Ministério da Saúde, 1996b.

MONTENEGRO, T. H. Tuberculose e literatura: notas de pesquisa. Rio de Janeiro, 1949.

MORSE, D.I. Terapêutica vigiada da tuberculose: gastar agora ou pagar depois. BMJ., 1 (11): 4-6, 1996.

MURRAY, C.J.L. et al. Tuberculosis en los países en desarrollo: magnitud, intervenciones y costos. Bol. Unión Int. Tuberc. Enferm. Respir., 65: 6-26, 1990.

NAGPAUL, D.R. La lucha antituberculosa en el mundo en desarrollo: hay que cambiar de rumbo. Foro Mundial de la Salud. 5: 127-29, 1984.

NETTO, J.P.; CARVALHO, M.C.B. Cotidiano: conhecimento e crítica. 4.ed. São Paulo, Cortez, 1996.

NOVOCHADLO, M.A. da S. Conhecimentos e opiniões da população a respeito de doenças. Rev. Bras. Enferm., 37 (2): 87-9, 1984.

NUNN, $P$ et al.. The effect of human immunodeficiency virus type-1 on the infectiousness of tuberculosis. Tuberc. Lung Dis., 75: 25-32, 1994.

OLIVEIRA, H.B. Perfil dos pacientes reingressantes no sistema de notificação da tuberculose. In: Congresso Brasileiro de Saúde Coletiva, 5; Congresso Paulista de Saúde Pública, 5., Campinas, 1993-1994. Livro de resumos. São Paulo, Associação Brasileira de Pós-Graduação em Saúde Coletiva/ Associação Paulista de Saúde Pública/ Faculdade de Saúde Pública da Universidade de São Paulo. 1997. p. 71.

ORGANIZACIÓN DE COOPERACIÓN Y DESARROLLO ECONÓMICOS (OCDE). Health care reform: issues for discussion. Paris, OCDE, 1994.

ORGANIZACIÓN PANAMERICANA DE LA SALUD (OPAS). Condiciones de salud en las Americas. Washington, D.C., 1990. v.1, p. 186-90. (OPAS Publicación Científica. 524). 


\section{ORGANIZACIÓN PANAMERICANA DE LA SALUD (OPAS). Condiciones de} salud en las Americas. Washington, D.C., 1994. v.1, p.179-83, 1990. (OPAS Publicación Científica, 549).

PARSONS, T. The social system. New York, The Free Press, 1951.

PARSONS, T. The sick role and the role of the physician reconsidered. Health and Soc., p: 257-78, Summer, 1975.

PORTA, M. La compliance in neurologia. Milano, Utet Periodici Scientifici, 1994.

PORTER, J.D.H.\& McADAM, K.P.W.J. The re-emergence of tuberculosis. Ann. Rev. Public Health., 15: 303-23, 1994.

POZSIK, C.J. Compliance with tuberculosis therapy. Med. Clin. North Am., 77: 12891301, 1993.

PREZ, R. M. des \& HEIM, C.R. Mycobacterium tuberculosis. In: Mandell, G.L. et al. Principles and practice of infectious diseases. 3.ed. New York, Churchill Livingstone, 1990. p. 1877-905.

RAMACHANDRAN, P. \& PRABHAKAR, R. Defaults, defaulter action and retrieval of patients during studies on tuberculous meningitis in children. Tuberc. Lung Dis., 73: 170-3, 1992.

RAVIGLIONE, M.C. et al. Global epidemiology of tuberculosis: morbidity and mortality of a worldwide epidemic. JAMA., 273: 220-6, 1995.

RIBEIRO, L. A luta contra a tuberculose no Brasil: apontamentos para uma história. Rio de Janeiro, Ed. Sul Americana. 1956.

ROSA, M.L.G. Duque de Caxias: medicina e exclusão. Saúde em Debate. 31: 37-42, 1991.

ROSEN, G. Da polícia médica à medicina social: ensaios sobre a história da assistência médica. Rio de Janeiro, Graal, 1979. p.171-90.

ROSEN, G. Uma história da saúde pública. São Paulo, Hucitec/UNESP/ABRASCO, 1994.

ROUILLON, A. Problems in organising effective ambulatory treatment of tuberculosis patients. Bull. Int. Union Tuberc., 47: 68-83, 1972.

ROZEMBERG, B. Representação social de eventos ligados à esquistossomose. Cad. Saúde Pública., 10: 30-46, 1994.

RUBEL, A.J. \& GARRO, L.C. Social and cultural factors in the successful control of tuberculosis. Public Health Rep., 107: 626-36, 1992. 
RYAN, F. The forgotten plague: how the battle against tuberculosis was won-and

lost. Boston, Little, Brown and Company, 1992.

SAMARASINGHE, et al. Intermittent supervised treatment of tuberculosis at Green Lane Hospital, 1987-8. N. Z. Med. J., 105: 243-5, 1991.

SANTOS, L. A . de C. Linhagens e perspectivas: a saúde na América Latina. Hist. Ciênc. Saúde., 4: 185-95, 1997.

SÃO PAULO. Secretaria de Estado da Saúde. Centro de Vigilância Epidemiológica. Tuberculose: um desafio. São Paulo, Fundação Nacional de Saúde, Secretaria de Estado da Saúde, 1993.

SÃO PAULO. Secretaria de Estado da Saúde. Programa de Controle da Tuberculose. São Paulo, s/d.

SBARBARO, J. Cumplimiento del paciente con el tratamiento preventivo. Consideraciones operacionales. Bol. Unión Int. Tuberc. Enferm. Respir., 66 (Supl.): 39-41, 1990/1991.

SHIRASSU, M.M.et al. Tuberculose: rendimento do tratamento e fatores associados ao abandono. In: Congresso Brasileiro de Saúde Coletiva, 5.; Congresso Paulista de Saúde Pública, 5., Águas de Lindóia, 1997. Livro de resumos. São Paulo, Associação Brasileira de Pós-Graduação em Saúde Coletiva/ Associação Paulista de Saúde Pública/ Faculdade de Saúde Pública da Universidade de São Paulo, 1997. p. 71 .

SMITH, R. \& OLIVEIRA, A.A. de. Integração social ou novas relações entre Estado e sociedade no Brasil. Rev. Estud. Avanç., 9: 117-39, 1995.

STEAD, W.W. \& BATES, J.H. Geographic and evolutionary epidemiology of tuberculosis. In: Rom, W.N. \& Garay, S. Tuberculosis. New york, Little, Brown and Company, 1996. p. 77-83.

SUKRAKANCHANA, T.P. et al. 10 year assessment of treatment outcome among Cambodian refugees with sputum smear-positive tuberculosis e Khao-I-Dang, Thailand. Tuberc. Lung Dis., 73: 384-7, 1992.

SUMARTOJO, E. When tuberculosis treatment fails: a social behavioral account of patient adherent. Am. Rev. Respir. Dis., 147: 1311-20, 1993.

SUTHERLAND, I. Recent studies in the epidemiology of tuberculosis, based on the risk of being infected with tubercle bacilli. Adv. Tuberc. Res., 19: 1-63, 1976.

TAKAHASHI, R.F. A singularidade e a sociabilidade de vivenciar a "TuberculAIDS": a morte anunciada. São Paulo, 1997. [Tese de Doutorado - Escola de Enfermagem da USP]. 
TOMAN, K. Tuberculosis-detección de casos y quimioterapia: perguntas y respuestas. Washington, D.C., Organización Panamericana de la Salud., 1980. (OPAS - Publicación Científica 392).

TRIPATHY, S.P. Madras study of intermittent oral chemotherapy. Bull. Int. U. Tuberc., 47: 30-6, 1972.

TUBERCULOSIS CHEMOTHERAPY CENTRE. A controlled comparison of a twicewekly and three once-weekly regimens in the initial treatment of pulmonary tuberculosis. Bull. World Health Organization., 43: 143, 1970.

VAN DER WERF; T.S. \& DADE, G.K.V.M. Patient compliance with tuberculosis treatment in Ghana: factors influencing adherence to therapy in a rural service programme. Tubercle., 71: 247-52, 1990.

WEIS, S.E. et al. The effect of directly observed therapy on the rates of drug resistance and relapse in tuberculosis. N. Engl. J. Med., 330: 1179-84, 1994.

WILKINSON, D. High-compliance tuberculosis treatment programme in a rural community. Lancet., 343: 647-8, 1994.

WORLD BANK. World development report 1993: investing in health. Washington, D.C., World Bank, 1993.

WORLD HEALTH ORGANIZATION (WHO). Division of Communicable Diseases. Tuberculosis Research and Development. Geneva. World Health Organization, 1990, 29 p.

WORLD HEALTH ORGANIZATION (WHO). Tuberculosis control and research strategies for the 1990s: memorandum from a World Health Organization meeting. Bull. World Health Organ., 70: 17-21, 1992.

WORLD HEALTH ORGANIZATION (WHO). Division of Communicable Diseases. Tuberculosis Research and Development. Geneva. World Health Organization, WHA/14, may, 1993a.

WORLD HEALTH ORGANIZATION (WHO). TB: a global emergency. World health. n.4, 1993 b.

WORLD HEALTH ORGANIZATION (WHO). Treatment of tuberculosis: guidelines for national programmes. 2.ed. Geneva, World Health Organization. 1997.

YÁNEZ, A et al. La infección por VIH y sus consecuencias para la endemia tuberculosa en Chile. Bol. Oficina Sanit. Panam., 119: 166-78, 1995. 
Anescos 


\section{ANEXO I \\ Formulário para realização de entrevista}

\section{Identificação:}

1.1. Nome do paciente:

1.2. $\mathrm{N}^{\circ}$ da entrevista:

1.3. Registro na UBS:

1.4. Data de realização da entrevista:

1.5. Endereço:

1.6. Sexo:

1.7. Idade:

1.8. Naturalidade:

1.9. Procedência:

1.10.Tempo de moradia no local atual:

1.11.Qual é a sua religião?

1.12. Você frequentou escola? ( )sim ( )não

Se sim, até qual série?

Se não, vocề sabe ler e escrever? ( )sim () não

1.13. Com quem você mora?

1.14. Você tem companheiro? ( )sim ( )não

1.15. Quantos filhos você tem?

\section{Dados sócio-econômicos:}

2.1. Você trabalha fora de casa?

( )sim. Onde você trabalha?

Quantas horas por dia/semana você trabalha?

Você tem carteira de trabalho assinada? ( )sim ( ) não

Você precisou estudar ou fazer algum curso para poder fazer seu trabalho?

( ) sim ( ) não

( )não

( )desempregado. Neste caso, em que você trabalhava?

Há quanto tempo você está desempregado?

() aposentado

Como você se sustenta sem seu emprego?

2.2. Você é responsável pelo trabalho doméstico em sua casa?

( )sim ( )não () em parte

2.3. Você tem Instituto ou Seguro Privado? ( )sim ( )não

2.4. Quanto você recebe por seu trabalho?
() menos de $1 \mathrm{sm}$
( )até $1 \mathrm{sm}$
()até $2 \mathrm{sm}$
( )até $3 \mathrm{sm}$
( )mais de $3 \mathrm{sm}$

2.5. Quantos membros de sua familia trabalham?

Em que trabalham?

2.6. Qual a renda de toda sua familia?
() menos de $1 \mathrm{sm}$
()até $1 \mathrm{sm}$
( )até $2 \mathrm{sm}$
( )até $3 \mathrm{sm}$
()mais de $3 \mathrm{sm}$ 
2.7. A sua casa é: () própria () alugada () financiada
( ) cedida
( ) outro
( ) de alvenaria
( ) de madeira
( ) barraco
( ) outro.
( ) 1 cômodo ( ) 2 cômodos
( ) 3 cômodos ( ) mais de 3 cômodos

2.8. Que beneficios tem a sua casa?
( ) rede elétrica
( ) asfalto
( ) água encanada
( ) filtro
( ) coleta de lixo vezes por semana
( ) rede de esgoto () fossa () esgoto a céu aberto

2.9. Você utiliza quais meios de transporte?
( ) ônibus
( ) carro próprio
( ) bicicleta
( ) outros.

2.10.Que grupos comunitários existem no seu bairro?

2.11.Você participa de algum grupo em sua comunidade?

( ) sim. Quais grupos?.

( ) não. Por que não participa?

( ) às vezes

\section{Processo saúde-doenca:}

3.1. Para você, o que foi ter tuberculose?

3.2. Como você se sentia durante o tratamento?

3.3. O que levou você a fazer o tratamento até o final? 
ANEXO II

\section{Roteiro de apresentação da pesquisadora aos pacientes}

\section{Bom dia!}

Meu nome é Maria Rita Bertolozzi e estou trabalhando com pessoas que já tiveram tuberculose ou que ainda estão com a doença.

Eu gostaria que o Sr. (a) colaborasse na realização de um estudo, respondendo algumas perguntas, que devem levar aproximadamente 30 minutos.

Para ser fiel ao que o Sr. (a) irá me dizer, a entrevista deve ser gravada, mas eu lhe asseguro que todas as informações serão mantidas em sigilo.

O Sr. (a) teria disponibilidade?

Obrigada 


\section{ANEXO III}

\section{Sistematizacão das frases temáticas segundo as categorias analíticas}

* O primeiro número refere-se à identificação do doente e o segundo número refere-se à ordem de classificação da frase

\section{As representações sobre o processo saúde-doença:}

- denominação/caracterização da tuberculose: $1.12 ; 3.2 ; 4.26 ; 5.19 ; 5.30 ; 7.5 ; 8.5 ; 9.7$; $10.4 ; 11.16 ; 11.26 ; 14.17 ; 15.25 ; 16.9$.

- associação à sinais e sintomas e associação com outras doenças: $1.1 ; 2.2 ; 2.3 ; 2.14$; $2.20 ; 3.1 ; 4.3 ; 4.4 ; 5.7 ; 5.35 ; 5.36 ; 5.37 ; 8.1 ; 8.2 ; 9.3 ; 9.5 ; 9.6 ; 10.2 ; 11.1 ; 11.11 ; 12.2$; $13.5 ; 15.1 ; 16.1 ; 16.4 ; 16.6 ; 17.5 ; 17.18$.

- associação a conceitos:

- temperatura/ventilação: $1.21 ; 2.39 ; 9.4 ; 11.13 ; 12.16 ; 13.11 ; 15.17 ; 17.2$

- imagens/metáforas: $8.6 ; 18.1 ; 18.5$

- alimentação/peso: $2.1 ; 4.34 ; 5.16 ; 5.17 ; 5.26 ; 5.27 ; 11.11 ; 16.6$

- fumo/álcool: 5.13

- trabalho: $5.26 ; 10.1 ; 10.7 ; 12.16 ; 14.1 ; 17.4$

- morte/vida: $3.5 ; 4.6 ; 7.6$.

- resistência/suscetibilidade: 9.20

- isolamento/internação: $4.10 ; 17.14$

- normal/patológico: $1.4 ; 1.5 ; 1.7 ; 12.14$

- estado/processo: $4.1 ; 11.4 ; 13.3$

- magnitude/complexidade: 17.27

- particularidade/subjetividade: $4.12 ; 4.39 ; 5.10$

- informação/saber: $3.4 ; 3.6 ; 3.8 ; 5.5 ; 6.18 ; 7.4 ; 10.5 ; 13.4 ; 13.22 ; 14.25 ; 16.10 ; 17.6$; 18.7

- representações sobre o diagnóstico:

- negativas: relacionadas à imagem de doença incurável/ gravidade/ preconceito/ afastamento/ desconhecimento/ trabalho: $1.9 ; 1.22 ; 2.16 ; 4.14 ; 5.12 ; 6.6 ; 8.9 ; 10.11$; $11.12 ; 12.13 ; 14.30 ; 15.4 ; 16.3 ; 17.8$

- positivas: descoberta/revelação: $2.13 ; 2.45 ; 14.44$

- representações sobre a causa da tuberculose:

- conseqüente ao próprio indivíduo: $2.31 ; 4.7 ; 4.22 ; 4.23 ; 13.1 ; 14.52$

- fatores externos: $4.8 ; 6.5 ; 7.3 ; 14.50 ; 14.54 ; 17.28 ; 18.6$

- independente/aleatória: $10.21 ; 12.28$

- representações sobre a fonte de infecção: $1.13 ; 1.14 ; 10.18 ; 11.22 ; 12.15 ; 15.3$

- representações sobre os exames para o diagnóstico: $2.8 ; 2.53 ; 5.9 ; 12.4 ; 14.31 ; 14.34$

- representações sobre as orientações/condutas frente à doença: $1.10 ; 1.11 ; 1.17 ; 10.19$ 
- representações sobre a internação/tratamento ambulatorial/domiciliar: $5.11 ; 14.8$;

$14.13 ; 14.14 ; 14.36 ; 14.20 ; 17.15$

- representações sobre a cura/ sucesso do tratamento: $8.17 ; 10.12 ; 11.9 ; 12.19 ; 12.30$; $12.31 ; 14.38 ; 14.39 ; 14.41 ; 14.59 ; 15.6 ; 17.19 ; 18.22$

- Mudanças/transformações na vida do doente: $13.12 ; 14.46$

- forma de pensar a vida: $2.25 ; 2.33 ; 2.40 ; 2.44 ; 2.46 ; 12.26 ; 15.15 ; 17.26$

- relacionamento com outras pessoas: $2.27 ; 2.29 ; 2.30 ; 2.32 ; 3.14 ; 3.15 ; 4.19 ; 5.15$; $6.13 ; 10.20 ; 13.10 ; 14.53$;

- cotidiano: $1.20 ; 2.15 ; 2.36 ; 2.42 ; 3.15 ; 3.25 ; 4.2 ; 5.45 ; 6.1 ; 6.14 ; 7.16 ; 7.17 ; 9.12$; $10.20 ; 11.18 ; 11.20 ; 12.26 ; 14.3 ; 14.23 ; 15.9 ; 15.15 ; 15.27 ; 17.26 ; 17.35$

- Sentimentos que afloram em virtude da doença: $2.47 ; 5.14 ; 5.22 ; 7.15 ; 15.7 ; 8.13$; $9.10 ; 11.7 ; 11.10 ; 14.5$;

- Preconceito/ Discriminação: $2.28 ; 3.16 ; 4.20 ; 5.12 ; 5.21 ; 5.40 ; 5.41 ; 6.15 ; 6.19 ; 7.10$; $7.11 ; 8.12 ; 10.16 ; 10.17 ; 11.17 ; 12.17 ; 12.18 ; 13.13 ; 13.15 ; 14.45 ; 16.8 ; 17.16 ; 17.20$; $17.31 ; 18.13$

- Necessidades do doente:

- em relação ao apoio/estímulo de pessoas: $1.3 ; 3.7 ; 14.16 ; 14.18$

- em relação ao âmbito religioso/ espiritual: $14.37 ; 14.40$

\section{Representações sobre a assistência à saúde:}

- representações sobre a busca de assistência: 1.6, 2.4, 4.9, 4.11, 4.13, 5.6, 7.1, 8.3, 9.9, $9.22,10.3,11.2,12.1,12.11,13.2,14.2,14.6,15.2,15.26,17.3,17.7$.

- identificação dos profissionais prestadores da assistência: $1.2 ; 2.5 ; 2.10 ; 2.50 ; 4.18$; $5.18 ; 5.42 ; 6.11 ; 7.12 ; 8.7 ; 8.8 ; 9.24 ; 10.6 ; 11.23 ; 12.3 ; 12.8 ; 14.7 ; 15.13 ; 15.21 ; 17.9$; 18.3

- exames que subsidiam o diagnóstico: $1.8 ; 2.6 ; 2.7 ; 2.11$

- diagnóstico: $2.9 ; 14.4 ; 14.24 ; 14.28 ; 14.29$

- concepção sobre a unidade de saúde: $2.48 ; 3.19 ; 5.20 ; 7.2 ; 18.14$

- atitude/conduta dos profissionais em relação à doença/doente: $2.49 ; 3.22 ; 5.24 ; 5.31$; $8.21 ; 8.22 ; 9.26 ; 11.5 ; 13.16 ; 14.26 ; 14.33 ; 17.11 ; 17.12$

- acessibilidade: $3.3 ; 4.5 ; 4.36 ; 5.3 ; 5.4 ; 5.8 ; 6.2 ; 9.8 ; 11.3 ; 14.9 ; 18.18$

- organização do serviço: $4.38 ; 14.12 ; 14.32$ 
- representação sobre os profissionais de saúde/assistência prestada: $5.25 ; 5.28 ; 8.20$; $9.25 ; 10.9 ; 10.10 ; 12.6 ; 12.11 ; 12.12 ; 12.23 ; 14.15 ; 14.21 ; 14.22 ; 14.27 ; 14.51 ; 14.56$; $14.61 ; 15.18 ; 15.19 ; 15.20 ; 15.22 ; 17.30 ; 18.8 ; 18.15 ; 18.16 ; 18.17$.

- orientações em relação à doença/tratamento: $2.18 ; 3.9 ; 6.7 ; 7.13 ; 14.43 ; 17.10 ; 17.13$

\section{Representações sobre o tratamento:}

- concepções sobre o tratamento: $1.15 ; 2.17 ; 2.21 ; 3.10 ; 3.11 ; 6.3 ; 6.10 ; 7.9 ; 8.10 ; 9.14$; $10.13 ; 11.14 ; 11.15 ; 11.24 ; 13.19 ; 14.35 ; 15.10 ; 15.14 ; 16.5 ; 17.21 ; 17.32$

- em relação à concepção do tratamento: $2.22 ; 2.23 ; 2.37 ; 4.15 ; 4.25 ; 4.31 ; 4.32 ; 5.1$; $5.34 ; 6.12 ; 7.8 ; 7.27 ; 7.28 ; 8.14 ; 8.18 ; 8.19 ; 9.13 ; 9.21 ; 9.27 ; 11.25 ; 12.9 ; 12.10 ; 12.25$; $13.9 ; 14.10 ; 14.11 ; 15.11 ; 17.25 ; 18.2 ; 18.10 ; 18.12 ; 18.21$

- em relação à sua associação com outros "tratamentos": $1.16 ; 2.38 ; 3.18 ; 7.23 ; 7.25$; 12.21

- em relação aos efeitos do tratamento medicamentoso: $2.19 ; 3.12 ; 3.13 ; 4.16 ; 4.24$; $4.28 ; 4.29 ; 4.30 ; 5.39 ; 6.9 ; 7.19 ; 7.26 ; 8.11 ; 9.15 ; 9.17 ; 12.22 ; 12.24 ; 14.42 ; 16.13$; $17.22 ; 17.23 ; 18.11$

\section{III.1. Representações sobre a adesão ao tratamento:}

- em relação ao papel dos familiares/profissionais/outros: $1.18 ; 2.26 ; 2.34 ; 2.35 ; 3.17$; $3.20 ; 3.23 ; 3.24 ; 4.21 ; 4.27 ; 5.2 ; 6.8 ; 7.20 ; 7.21 ; 9.19 ; 10.8 ; 10.15 ; 10.22 ; 12.32$; $13.7 ; 15.12 ; 16.11 ; 17.29$

- em relação à sua articulação/associação com outras questões: $1.19 ; 7.18 ; 9.16 ; 15.24$

- em relação a um projeto/objetivo/fim: $1.23 ; 2.41 ; 2.43 ; 4.17 ; 6.17 ; 7.14 ; 8.15 ; 8.16$; $9.18 ; 10.14 ; 10.23 ; 12.29 ; 13.8 ; 13.18 ; 16.12 ; 18.19$

- fatores relacionados à adesão ao tratamento: $1.24 ; 2.24 ; 3.21 ; 4.35 ; 4.37 ; 5.32 ; 5.33$; $6.16 ; 7.24 ; 9.23 ; 10.24 ; 11.19 ; 11.21 ; 12.20 ; 12.27 ; 13.14 ; 13.17 ; 13.20 ; 13.21 ; 14.48$; $14.49 ; 14.55 ; 14.58 ; 16.7 ; 17.24 ; 17.33 ; 17.34 ; 17.36 ; 18.20$ 


\section{ANEXO IV}

\section{Frases temáticas resultantes das análises dos depoimentos dos ex-doentes}

\section{TEMAS * Observação: a sigla "tb" significa "tuberculose"}

\section{ENTREVISTA 1}

Sinais e Sintomas: dor de cabeça, febre

TRAJETÓRIA: Sinais e Sintomas $\rightarrow$ Hospital de Jandira $\rightarrow$ bronquite $\rightarrow$ internação ( 7 dias) $\rightarrow$ internação (7dias) rouquidão $\rightarrow$ Hospital Universitário $\rightarrow$ exame de escarro $\rightarrow$ Tuberculose $\rightarrow$ Unidade Básica de Saúde

1.1. A doença/tb é associada a sinais e sintomas, iniciando por outra doença (bronquite)

1.2. Os prestadores da assistência à saúde não são denominados, nem identificados por categoria profissional ("eles")

1.3. A manutenção do quadro de sintomas e a internação posterior impelem o doente a compartilhar a sua situação com outrem

1.4. Para o doente, o encadeamento doença-tratamento-cura tem um "padrão", considerado "normal"

1.5. A manutenção da sintomatologia é considerada anormal pois rompe com o processo doençatratamento-cura

1.6. O empregador determina a busca da assistência à saúde

1.7. O processo saúde-doença está dividido em dois momentos: normal (desempenho das atividades do cotidiano e do trabalho) e doença (início da sintomatologia)

1.8. O diagnóstico médico é pautado pelo resultado do exame de escarro

1.9. O conhecimento sobre o diagnóstico provoca "abalo", devido ao desconhecimento da possibilidade de cura da doença

1.10. A orientação do empregador ao empregado/doente se concentra na ingestão dos medicamentos, no impedimento do contato (físico) com outras pessoas, na necessidade de lavagem cuidadosa de objetos pessoais, para ter/levar uma "vida normal"

1.11. A orientação do empregador para o empregado/doente "levar uma vida normal" provoca "calma" no doente

1.12. A tuberculose é denominada como "isso"

1.13. O diagnóstico determina com que o empregador tenha como principal foco de indagação, a fonte de transmissão da doença/tb, uma vez que o doente não se relaciona com outras pessoas

1.14. O doente desconhece a fonte de transmissão da doença/tb

1.15. O tratamento medicamentoso aumenta o apetite do doente

1.16. O tratamento medicamentoso está associado à ingestão aumentada de líquidos e de alimentação

1.17. A proximidade física com o doente determina a necessidade de uso de medicação pelos familiares

1.18. O estímulo materno e do empregador, materializados sob a forma de "conversa", ajudam o tratamento

1.19. A adesão ao tratamento está articulada à rotina do cotidiano

1.20. A doença/tb provoca mudanças na vida do doente e da família (filho) (não sair para não tomar friagem, não tomar refrigerante, tomar sucos)

1.21. A doença/tb está associada ao conceito de frio/gelado e à regulação da vida

1.22. O doente supõe que o diagnóstico determine que o empregador o demita/afaste do trabalho

1.23. A busca pela melhora da sintomatologia determina o seguimento do tratamento completo 
1.24. O seguimento do tratamento medicamentoso, a não exposição a substâncias frias/geladas/ambiente frio, bem como "fazer tudo certo", principalmente durante o primeiro mês, são as atitudes mais importantes durante o tratamento 


\section{ENTREVISTA 2}

Sinais e Sintomas: tontura, fraqueza, sudorese noturna, tosse, perda de peso

TRAJETÓRIA: clínica particular $\rightarrow$ exame de sangue/urina $\rightarrow$ Ceclor $\rightarrow$ tontura/perda de peso $\rightarrow$ clínica particular $\rightarrow$ exame de sangue $\rightarrow$ Tuberculose $\rightarrow$ Unidade Básica de Saúde $\rightarrow$ Raio X

2.1. O início da doença/tb não foi acompanhado por diminuição do apetite

2.2. O início da doença/tb é detectado pelo aparecimento súbito de febre alta

2.3. A doença/tb é associada a sintomas

2.4. A busca da assistência à saúde ocorre a partir do surgimento de sinais e sintomas

2.5. O protagonista da assistência à saúde, na clínica particular, é o médico não denominado ("ele")

2.6. Os exames têm alteração somente quando a doença/tb está em plena evolução

2.7. O diagnóstico médico pauta-se na realização de exames laboratoriais: sangue e urina

2.8. O conjunto de sinais e sintomas determina a solicitação de teste de HIV

2.9. Mesmo na incerteza do diagnóstico, o início do tratamento para a tb/AIDS seria efetivado

2.10. A protagonista da assistência à saúde na UBS é a médica "denominada"

2.11. A realização de exames é fundamental para orientar a prescrição médica

2.12. A magnitude da doença/tb é evidenciada pela observação da radiografia, provocando sentimento de "susto"

2.13. O esclarecimento do diagnóstico de tuberculose provoca "alívio"

2.14. O definhamento/emagrecimento não são tomados como manifestação da doença/tb

2.15. A doença/tb determina alteração das atividades escolares

2.16. A revelação do diagnóstico é tomada como o momento mais grave de evolução da doença/tb

2.17. O tratamento medicamentoso determina a melhora da doença/tb

2.18. Existe orientação médica quanto aos efeitos colaterais dos medicamentos

2.19. Os efeitos colaterais dos medicamentos (dor no estômago) se efetivam somente quando da ausência de ingesta alimentar

2.20. Escarrar sangue provoca "preocupação"

2.21. A evolução positiva da doença/tb durante o tratamento não se dá segundo o esperado pelo profissional médico

2.22. O tratamento medicamentoso é um processo rotineiro/normal, incorporado ao cotidiano

2.23. O incômodo de tomar a medicação efetiva-se devido ao horário

2.24. A ruptura do cotidiano com um fato empolgante, que causa ansiedade, é o único fator que leva à interrupção momentânea da medicação

2.25. A doença/tb causa mudança na vida do doente, em termos de conscientizá-lo sobre a sua fragilidade, possibilidade de morrer e sua relação com familiares e amigos, pois ocorre maior solidariedade

2.26. A solidariedade por parte de familiar (tia) é apontada pelo doente como positiva e se expressa pelo seu deslocamento de local distante para preparar alimento

2.27. A doença/tb faz constatar sobre a real possibilidade de ajuda dos amigos (limitada ou ausente)

2.28. A doença/tb não é divulgada desde o início para os amigos devido a "receio"

2.29. A doença/tb determina o "fechamento" no relacionamento com os amigos

2.30. O cuidado "excessivo" por parte de alguns é tido como "bajulação" e determina o recuar/retrair no relacionamento com as pessoas

2.31. A tuberculose é causada por "depressão", secundária à ruptura no relacionamento amoroso, não dormir e não comer bem, viagens rápidas e freqüentes

2.32. O "recuo"/retração em relação às pessoas é uma atitude que causa "mal estar" ao doente

2.33. A doença/tb leva ao fortalecimento pessoal, a "encarar mais as coisas", a acreditar mais em si mesmo. enquanto potencialidade e capacidade 
2.34. A figura materna ajuda no tratamento pelo fato de estar próxima

2.35. O sucesso do tratamento depende da proximidade materna, da "obstinação" do paciente, da ajuda dos familiares/padre, da observação "positiva" de vizinhos sobre a aparência do doente, do cuidado de alguns amigos em relação ao "excesso físico"

2.36. A limitação às atividades esportivas que a doença/tb causa somente é evidenciada a partir das orientações de amigos

2.37. O doente tem consciência sobre a morosidade da duração do tratamento

2.38. O tratamento inclui a não exposição ao frio

2.39. A doença/tb condiciona comportamento posterior de não exposição ao frio

2.40. A doença/tb determina "medo" subsequente de adoecer

2.41. O tratamento completo se deve ao desejo de "ficar bom"

2.42. A doença/tb impede o desenvolvimento normal de atividades do cotidiano e determina "deixar de sair à noite" e reduzir a prática de esportes

2.43. O tratamento completo integral depende do comportamento "teimosia" e de obstinação: "querer ir até o fim"

2.44. A doença/tb faz valorizar a vida

2.45. O diagnóstico precoce fortalece o projeto de "querer viver"

2.46. A doença/tb causa sofrimento para o doente e para aqueles que com ele convivem

2.47. O sofrimento guarda correlação com a idade da pessoa (é maior, quanto mais jovem), uma vez que diminui a "potencialidade" de viver

2.48. A unidade de saúde alberga parte da vivência do processo saúde-doença ("foi ali que tudo começou")

2.49. A "preocupação" com o desenvolvimento do processo saúde-doença por parte da equipe de saúde é apontada como importante para o doente

2.50. A equipe de saúde é a protagonista da assistência, no âmbito da UBS

2.53. Para o doente, o RX é um parâmetro do seu estado/situação em relação à doença/tb 


\section{ENTREVISTA 3}

Sinais e Sintomas: tosse, febre, fraqueza, emagrecimento

TRAJETÓRIA: 5 hospitais $\rightarrow$ sem diagnóstico $\rightarrow 6^{\circ}$ local: Hospital Universitário $\rightarrow$ Tuberculose (1 semana) $\rightarrow 7^{\circ}$ local: Unidade Básica de Saúde (UBS) $\rightarrow$ efeitos colaterais dos medicamentos, pois estava tomando em dose inadequada/ efeitos colaterais em intensidade $\rightarrow 8^{\circ}$ local: Clemente Ferreira $\rightarrow$ mudança na quantidade de medicamentos, melhora $\rightarrow 9^{\circ}$ local: UBS $\rightarrow$ continuação do tratamento

\subsection{Estar doente é associado a sintomas}

3.2. A Tuberculose não é denominada ("essa doença", "isso")

3.3. Dificuldade de acessibilidade ao serviço para diagnóstico ( 8 unidades percorridas)

3.4. A TV influencia a percepção do doente em relação à doença/tb

3.5. A complexidade da doença, enquanto passivel de morte, provoca sentimento de "medo"

3.6. $O$ doente manifesta ambigüidade quanto à recepção de informações sobre a doença

3.7. Há descrédito materno quanto à manifestação da doença/tb

3.8. Há desconhecimento quanto ao modo de transmissão da doença

3.9. Há ausência de orientações pelo médico/profissional de saúde, quanto ao modo de transmissão da doença

3.10. O tratamento medicamentoso no primeiro trimestre provoca mal estar físico ("sonolência", "fraqueza", "enjôo", "vômito", "dificuldade para andar", "dificuldade para comer", "só bebia água")

3.11. O tratamento medicamentoso, após o primeiro trimestre, melhora tosse, vômitos e fraqueza

3.12. As reações ao tratamento medicamentoso são atribuídas à superdosagem de medicamentos

3.13. As reações ao tratamento medicamentoso não impediram a sua continuidade

3.14. A tuberculose causa afastamento dos familiares e das atividades sociais ( "eu não saía")

3.15. A tuberculose leva ao isolamento físico e de comunicação verbal com as pessoas, à restrição da locomoção, à interrupção da prática de esportes, à interrupção da educação formal

3.16. O diagnóstico de tuberculose é divulgado somente aos familiares mais próximos (núcleo familiar)

3.17. O desejo manifesto de interromper o tratamento medicamentoso não é concretizado totalmente ("dia sim/dia não") devido ao estímulo paterno em primeiro lugar e, secundariamente devido à mãe e vizinha

3.18. O tratamento leigo ("benzedeira", "chá") é realizado e aceito pelo doente na independência do conhecimento do diagnóstico do "cuidador" ("ela cuidava de mim um pouco")

3.19. A importância da UBS está no estabelecimento do diagnóstico e prescrição de medicamentos

3.20. O estímulo paterno se efetiva através de "trazer o remédio", "conversar", "preparar alimento"

3.21. Seguir o tratamento medicamentoso, determinado pelo médico, é considerada a atitude mais importante

3.22. O protagonista da assistência é o profissional médico, que é referido como "ele"

3.22. O encaminhamento para o centro de referência (ICF) foi devido a problemas relacionados à dosagem e frequência da tomada de medicamentos

3.23. As figuras paterna, da mãe e da vizinha (materializada pela sua presença e pelo preparo de chás) ajudaram no tratamento

3.24. O fato das pessoas da família (de modo geral) não auxiliarem no tratamento é considerado como dificuldade no tratamento

3.25. A doença mudou a vida: o paciente deixou de sair de casa, fez mudar momentaneamente de moradia, na tentativa de ficar mais próximo à UBS 


\section{ENTREVISTA 4}

Sinais e Sintomas: febre, cansaço, “dor no peito", desânimo, emagrecimento

TRAJETÓRIA: sinais e sintomas (1mes) $\rightarrow$ convênio $\rightarrow$ Unidade Básica de Saúde

4.1. A doença/tb é definida como um estado (momento)

4.2. A doença/tb determina mudança de disposição, diminuição da capacidade para a realização de atividades do cotidiano, diminuição de "resistência fisica"

4.3. A sintomatologia não é associada à tuberculose (gripe, amigdalite, problemas na tireóide)

4.4. A "vulgarização" dos sintomas (gripe) acarreta a atitude de falta de importância em relação à doença/tb e a possibilidade de tratamento no âmbito doméstico (xarope)

4.5. A necessidade de realização de exames e de apresentação de "documentos" provoca a demora no início do tratamento ( 1 mês)

4.6. A doença/tb provoca sentimento de morte, que é superado pela "força pessoal"

4.7. O marido culpa a esposa pela causa/origem da doença no âmbito familiar, apesar de ser o primeiro a manifestar a doença/tb

4.8. A doença/tb é causada por alimentação inadequada, excesso de trabalho, fumo, álcool, café, contato íntimo direto, exposição à chuva

4.9. O marido é impelido a buscar assistência à saúde por determinação médica

4.10. A doença provoca choque/depressão ocasionado por interrupção do trabalho (demissão), afastamento de amigos

4.11. O "medo" da possível demissão, em função da doença/tb, determina a não busca de assistência à saúde

4.12. O processo saúde-doença dos familiares provoca maior preocupação que o próprio

4.13. A busca da assistência à saúde é definida pela situação-limite: possibilidade de abandono dos familiares

4.14. O diagnóstico provoca "mal estar", ocasionado pela surpresa, apesar da existência de familiar doente

4.15. O seguimento do tratamento é caracterizado como "terrível", devido aos efeitos colaterais dos medicamentos ("ânsia", "cheiro de enxofre na pele")

4.16. Os efeitos colaterais dos medicamentos não provocam a interrupção do tratamento

4.17. O seguimento do tratamento medicamentoso é resultado "da vontade de melhorar", do dever ("tenho que tomar") e do estímulo do profissional médico

4.18. A profissional médica (denominada) é a protagonista da assistência, por proporcionar confiança, permitir a acessibilidade do doente, estimular, mostrar-se disponível e valorizar a queixa do doente

4.19. A doença não determina o afastamento de amigos

4.20. O preconceito/discriminação dependem da cultura da região geográfica onde se vive

4.21. O estímulo da família é indicado como um fator importante no seguimento do tratamento

4.22. A constatação da "inocência/não culpa" da esposa na causação da TB em familiar (filha) leva a repensar sobre a determinação da doença por parte da figura paterna

4.23. A consciência de que o esposo disseminou a tuberculose no âmbito familiar não acarreta a sua culpabilização pelos acometidos

4.24. O tratamento medicamentoso no primeiro bimestre, provoca "depressão", sofrimento, "ódio", devido aos efeitos colaterais e desejo manifesto, porém não concretizado, de interromper o tratamento

4.25. A coloração dos medicamentos permite o seu reconhecimento

4.26. A doença/tb é caracterizada como um "problema" a ser resolvido

4.27. A adesão ao tratamento, por um dos membros da família. estimula o seu seguimento pelos demais 
4.28. As orientações sobre os efeitos colaterais dos medicamentos não são explicitadas integralmente pelo médico para não induzir o doente a senti-las

4.29. A rejeição medicamentosa é atribuída ao hábito de não tomar medicamentos e por acreditar que as doenças podem ser resolvidas no cotidiano, na forma de viver a vida

4.30. A necessidade de tomar os medicamentos e as reações advindas de seu uso provocam sentimento de ambigüidade

4.31. A prática religiosa é indicada como um fator desestimulante para o consumo de medicamentos no cotidiano

4.32. A necessidade de realizar o tratamento medicamentoso transgride o conceito de não tomar a medicação como um hábito

4.33. Há "inconformismo/impotência" diante da realidade: cuidado com a saúde $\mathrm{x}$ a aquisição da doença

4.34. O conceito de saúde incorpora a alimentação adequada (não forte, sem frituras)

4.35. A qualidade da assistência prestada na UBS e no Instituto Clemente Ferreira, materializada pela priorização no atendimento, em função do diagnóstico de Tuberculose, é indicada como um item importante no seguimento do tratamento

4.36. A doença/tb provoca discriminação que, paralelamente, garante na UBS, prioridade no atendimento

4.37. A organização do serviço de saúde (agendamento de consultas) é apontada como um item importante no seguimento do tratamento

4.38. A experiência positiva, em termos de organização do serviço de saúde, é veiculada (pelo próprio doente) para outro serviço de saúde

4.39. O conceito de saúde-doença é um processo individual, que não pode ser transmitido ao outro 


\section{ENTREVISTA 5}

Sinais e Sintomas: sudorese noturna, hemoptise, tosse, emagrecimento,

TRAJETÓRIA: Pronto Socorro do convênio $\rightarrow$ Hospital do convênio (Raio $X /$ exame de escarro) $\rightarrow$ Tuberculose $\rightarrow$ Unidade Básica de Saúde (UBS) (sem médico) $\rightarrow$ UBS

5.1. A quantidade de medicamentos a serem ingeridos é apontada como um fator negativo no tratamento

5.2. O apoio do empregador é apontado como positivo no tratamento

5.3. A busca da assistência à saúde evidencia "peregrinação" em função da falta de profissionais, falta de "vaga" e da necessidade de "guias" do convênio

5.4. A assistência só é prestada devido ao tipo de doença/tb

5.5. O doente desconhece a doença/tb

5.6. A busca da assistência à saúde se concretiza a partir da situação de emergência (escarrar sangue)

5.7. A hemoptise é tida como "anormal", ao contrário dos demais sinais e sintomas

5.8. A assistência no hospital do convênio se concretiza somente a partir da insistência do doente

5.9. O Raio- $X$ reflete a noção de gravidade da doença/tb e o exame de escarro evidencia o diagnóstico

5.10. O significado da doença/tb é diferente para o doente e para o médico

5.11. O significado da internação para o doente se baseia no desenvolvimento do seu cotidiano e para o médico no signo patológico

5.12. O diagnóstico de tuberculose e as medidas de precaução utilizadas no hospital (uso de máscaras) provocam "mal estar" emocional

5.13. A doença/tb está associada ao fumo e ao consumo de álcool

5.14. As medidas de precaução apresentam conotação de repulsa ("aquilo lá")

5.15. A doença/tb provoca perda/afastamento de amigos

5.16. O emagrecimento é o sinal de perigo/gravidade para a doença e provoca "pavor"

5.17. O emagrecimento é associado à outra doença (AIDS)

5.18. A equipe de saúde hospitalar é despersonalizada ("eles"), mas tem categoria profissional definida (assistente social, enfermeira, médico)

5.19. A doença, o hospital, o tratamento são citados indiretamente ("aquela doença", "lá", "disso", "horrível", "meio pesado")

5.20. A UBS é um local de distribuição de medicamentos

5.21. O cumprimento de ordens médicas (uso de objetos descartáveis) provoca "abalo" e estigmatização

5.22. As medidas para a diminuição da transmissão da doença (ventilação do domicílio) provocam "pavor" e medo de morte

5.23. A morte não é denominada pelo doente ("agora eu vou", "pessoa vai se apagar", "embarcar dessa para melhor")

5.24. O profissional médico reduz sua orientação específica ao doente, para o controle dos comunicantes ("fazer exame")

5.25. O profissional médico é o agente que diminui a ansiedade ocasionada pelo preconceito da doença/tb e faz modificar o sentimento de morte

5.26. A doença/tb é associada ao excesso de trabalho e ao acesso diferenciado à alimentação

5.27. O emagrecimento não é associado à tuberculose e sim ao diabetes

5.28. A expectativa do doente em relação ao trabalho do médico é o dever detectar todo tipo de disfunção (emagrecimento) e contorná-lo

5.29. A ruptura da expectativa do doente sobre o trabalho médico provoca sentimento de "decepção"

5.30. A doença/tb é tomada como "algo errado" 
5.31. A expectativa do profissional de saúde (assistente social) é que o doente, devido à sua diferenciação social, não deixe que a doença/tb atinja a situação-limite ("escarrar sangue") 5.32. O sucesso do tratamento, para o doente, depende do tratamento medicamentoso no período de tempo adequado e se materializa pelo ganho de peso

5.33. O sucesso do tratamento também do uso de ações caseiras ("inalação com eucalipto")

5.34. O doente apresenta conhecimento sobre a modificação do tratamento para a tuberculose, da época antiga à atualidade e de que a doença causava a morte

5.35. O início da enfermidade não se configura como doença/tb devido ao seu caráter "silencioso" ("sem dor")

5.36. A dor é o signo para caracterizar o "estado" doença

5.37. O caráter "silencioso" (sem dor) da doença/tb determina o "descaso" do doente ("não se cuida")

5.38. O doente apresenta conhecimento sobre a necessidade do tratamento correto e completo para chegar à cura

5.39. O doente apresenta conhecimento sobre os possiveis efeitos colaterais dos medicamentos

5.40. Existe preconceito/estigma dos outros em relação ao doente

5.41. O preconceito da doença/tb é decorrência da sua transmissão por via respiratória, uma vez que propicia maior disseminação

5.42. A profissional médica é a protagonista da assistência na UBS

5.41. O seguimento do tratamento ocorre em decorrência do estímulo/valorização do profissional médico, do vivenciado em função da mesma doença por amigo (perda de pulmão) e do medo da morte

5.42. O repouso e a manutenção do contato com amigos são as medidas mais importantes durante o tratamento

5.43. A doença determina o afastamento das atividades de trabalho, o ingresso no INSS, a mudança no nível econômico e no ritmo de vida

5.44. A ajuda financeira do empregador é indicada como importante para o seguimento do tratamento 


\section{ENTREVISTA 6}

Sinais e Sintomas: tosse, febre, dor nas costas, sensação de frio, cansaço, nervosismo, emagrecimento

TRAJETÓRIA: sinais e sintomas (15 dias) $\rightarrow$ Pronto-Socorro Iguatemi $\rightarrow$ Raio X, exame de sangue, exame de escarro $\rightarrow$ Hospital das Clínicas (HC) de São Paulo $\rightarrow$ HC Recife (3 meses) $\rightarrow$ Unidade Básica de Saúde São Paulo + Raio X Hospital Universitário

6.1. A doença/tb determina a interrupção do hábito de fumar e ingestão de álcool, causa "nervosismo" e interrupção parcial das atividades referentes ao trabalho ( 3 meses)

6.2. A morosidade na assistência em São Paulo provoca busca de assistência à saúde em outro Estado

6.3. O sucesso do tratamento é evidenciado por ganho de peso

6.4. A doença/tb não é denominada

6.5. A doença é provocada por falta de alimentação

6.6. O diagnóstico de tuberculose provoca "tristeza" devido à necessidade de afastamento (físico e de objetos) dos familiares e ao desabastecimento de alimentação para a família causado pelo afastamento do trabalho

6.7. O doente manifesta ambigüidade sobre o conteúdo das orientações médicas no que se refere à necessidade de separação de objetos pessoais

6.8. O sucesso do tratamento é obtido através do apoio dos familiares (esposa e irmãs) no preparo de alimentos "fortes" e na "obtenção de vaga" no serviço de saúde

6.9. O tratamento medicamentoso provoca reação ("coceira") que não impede a sua continuidade

6.10. A melhora da sintomatologia é observada a partir de 15 dias do início do tratamento medicamentoso

6.11. A protagonista da assistência à saúde é a profissional médica (não denominada)

6.12. A coloração dos medicamentos é a referência sobre a sua diferenciação

6.13. A doença/tb provoca mudanças na vida, no que se refere ao isolamento em relação aos familiares

6.14. A interrupção das atividades profissionais do doente é determinada pelo profissional médico, em decorrência da evolução da doença/tb

6.15. A doença/tb não é divulgada pelo doente fora do ambiente familiar

6.16. A facilidade de acesso, a rapidez de atendimento e a não necessidade de internação, são apontados como fatores que auxiliam no seguimento do tratamento

6.17. O seguimento do tratamento ocorre devido à força de vontade, à "vontade de sarar" e de continuar a trabalhar

6.18. A doença/tb, apesar de ter-se constituído em problema em época antiga, hoje é tomada como normal/regular ("não é nada do outro mundo")

6.19. A doença/tb provoca preconceito, dos outros em relação ao doente e do doente em relação aos outros 


\section{ENTREVISTA 7}

Sinais e Sintomas: "gripe", tosse, cansaço, febre, dor no peito

TRAJETÓRIA: sinais e sintomas (l mes) $\rightarrow$ Caxias do Sul (clínica particular $\rightarrow$ penumologista particular $\rightarrow$ "unidade especializada" $\rightarrow$ Unidade Basica de Saúde em São Paulo

7.1. A busca de assistência à saúde é determinada pela figura materna

7.2. A assistência efetivada em unidade especializada é apontada como positiva, uma vez que trata do problema específico

7.3. A doença/tb é causada por excesso de trabalho; por imposição própria para o bom desempenho, por ocasião de um dever a cumprir; e pela alimentação inadequada, em função de medo de engordar

7.4. A sintomatologia não é associada à tuberculose devido ao desconhecimento da doença

7.5. A doença/tb é qualificada como "horrivel", "chata", "desconfortável" e não passível de cura

7.6. A doença/tb incorpora a noção e a sensação de morte e provoca "medo"

7.7. A doença/tb é um processo complexo ("não é ter uma gripe, um sarampo")

7.8. A necessidade de realizar o tratamento medicamentoso entra em choque com o hábito de não tomar medicamentos

7.9. O tratamento medicamentoso provoca melhora da sintomatologia, mas diminui a capacidade para locomoção

7.10. A doença/tb é divulgada sob a forma de "pneumonia"

7.11. A doença/tb provoca preconceito e "medo" do doente em relação aos outros e dos outros em relação ao doente

7.12. O protagonista da assistência é o médico (não denominado)

7.13. A orientação médica aponta para a necessidade de "normalizar " a vida e que a doença não provoque auto-comiseração

7.14. O seguimento do tratamento pelo doente é motivado pela necessidade de cuidar da filha (menor de idade); pela persistência/disciplina para, em última instância, poder modificar a vida $\mathrm{e}$ por não ter que re-vivenciar a doença

7.15. A doença provoca sofrimento nos familiares

7.16. A vivência da doença influencia o comportamento dos familiares (no que se refere à necessidade de alimentação adequada)

7.17. O medo da doença/tb determina a interrupção de regime (dieta) alimentar

7.18. O seguimento do tratamento medicamentoso é efetivado através de "estímulos" (colocar o medicamento em lugares estratégicos) que incorporam o medicamento ao cotidiano

7.19. O tratamento medicamentoso provoca reação ("gases") que não impede a sua continuidade

7.20. A distância fisica dos familiares é apontada como fator que dificulta o tratamento

7.21. O seguimento do tratamento ocorre pelo cuidado prestado por familiares

7.22. A doença/tb acomete os "disciplinados" e isso causa inconformismo

7.23. O sucesso do tratamento é atribuído também ao uso de substâncias naturais (ervas)

7.24. A assistência à saúde, concretizada pelos retornos subsequentes às consultas médicas; pela falta de seqüência/objetividade na abordagem do médico por ocasião dos retornos; pela falta de profissionais "especialistas"; pela associação da manifestação da tuberculose à AIDS pelo médico; pela necessidade de exame de escarro (cujo material não mais existia), são apontados como fatores que dificultam o tratamento

7.25. O sucesso do tratamento deve-se à incorporação do tratamento medicamentoso ao cotidiano, ainda que seja "desagradável"

7.26. A sensação de melhora, proporcionada pelo tratamento medicamentoso, suscita um sentimento ambíguo sobre a necessidade/vontade de tomar a medicação 
7.27. A possibilidade de ampliação do período de medicação diminui o sentimento de ambigüidade (sobre a necessidade/vontade de tomar a medicação) e determina a opção pelo seguimento do tratamento

7.28. O uso de comprimidos por via oral é apontado como positivo para o sucesso do tratamento 7.29. A possivel/potencial falta de medicamentos na UBS provoca "medo" no doente e determina a manutenção de um "estoque" medicamentoso em sua casa 


\section{ENTREVISTA 8}

Sinais e Sintomas: palidez, cor "amarelada", tontura, não sentia gosto nos alimentos, mal-estar desânimo, tosse, catarro "preto"

TRAJETÓRIA: sinais e sintomas $(3$ meses $) \rightarrow$ Hospital Universitário $\rightarrow$ Raio $X \rightarrow$ Tuberculose $\rightarrow$ Unidade Básica de Saúde

8.1. A sintomatologia não é associada à tuberculose, mas à "gripe"

8.2. A sintomatologia provoca "ansiedade e medo", uma vez que indica a presença de doença/tb $\epsilon$ a potencial necessidade de interrupção das atividades relacionadas ao trabalho

8.3. A busca da assistência à saúde ocorre na fase aguda da sintomatologia

8.4. O nome da doença/tb não é recordado pelo doente

8.5. A doença/tb não é denominada ("isso") pelo doente

8.6. A apreensão do doente em relação à orientação médica está centrada num "tuberculoso embutido dentro de mim"

8.7. A protagonista da assistência à saúde é a profissional médica, da UBS, caracterizada pela etnia (japonesa) e qualificada como "boa"

8.8. O protagonista da assistência no âmbito hospitalar é o profissional médico, cuja ação se restringe à prescrição de medicamentos e encaminhamentos

8.9. O diagnóstico provoca "susto" e incredulidade devido ao desconhecimento da doença/tb, mesmo que já tivesse acometido familiar

8.10. O tratamento medicamentoso provoca "fraqueza", "desânimo" e a melhora é percebida após o primeiro trimestre

8.11. Os efeitos causados pelos medicamentos não impedem a continuidade do trabalho

8.12. A doença/tb é divulgada no ambiente de trabalho

8.13. A doença/tb provoca "desânimo", "depressão" e "tristeza"

8.14. O tratamento para o doente limita-se ao uso contínuo da medicação

8.15. O seguimento do tratamento ocorreu devido ao desejo de "ter saúde" e ao estímulo imperativo/do interesse pelo estado de saúde pela profissional médica ("cuidado... a Sra. toma o remédio direito..."), pela disponibilidade dos medicamentos, e devido ao apoio dos familiares

8.16. O seguimento do tratamento está calcado na perspectiva da destruição do "negócio que tinha em mim"

8.17. A responsabilidade pela cura é remetida ao âmbito divino, que "ajuda", "dá força" em primeira instância, e à ingestão dos medicamentos

8.18. O seguimento do tratamento não é um processo "difícil" devido à crença divina

8.19. O sucesso do tratamento depende, em primeiro lugar, da interferência divina e, depois, da assistência médica

8.20. A assistência médica é qualificada como importante, pois o profissional médico "descobre o que se tem", ajuda e orienta

8.21. O profissional médico compartilha com a doente o sentimento de perda por ter que deixar a unidade de saúde

8.22. O profissional médico remete ao posicionamento político do doente a possibilidade de seu retorno ao trabalho na unidade de saúde 


\section{ENTREVISTA 9}

Sinais e Sintomas: resfriado, febre, tosse, hemoptise, emagrecimento, inapetência, cansaço

TRAJETÓRIA: sinais e sintomas (1 mês) $\rightarrow$ Unidade Básica de Saúde (UBS) Santo Amaro (não foi atendido $) \rightarrow$ Hospital Universitário $\rightarrow$ Hospital Bandeirantes $\rightarrow$ UBS

\subsection{O doente nega a recordação do início da doença/tb}

9.2. A figura materna determina a lembrança sobre o início da doença/tb

9.3. O início da sintomatologia da doença/tb é confundido com outra doença ("resfriado")

9.4. O surgimento da doença/tb está associado à ingestão de substância fria/gelada, no momento em que o corpo estava quente e à presença de sintomatologia

9.5. O conjunto de sinais e sintomas não determina a percepção sobre a doença/tb, mesmo que a doença já tivesse ocorrido anteriormente na família

9.6. Estar doente é associado à presença de sinais e sintomas

9.7. A tuberculose não é denominada

9.8. Existe dificuldade de acessibilidade à unidade de saúde ("sem atendimento", "sem funcionários", demora)

9.9. O volume de sangue perdido pela hemoptise é o determinante para a busca da assistência à saúde

9.10. A perda de sangue define a situação-limite da gravidade da doença e causa "medo", pois a primeira doença a ser pensada é a AIDS

9.11. O diagnóstico é tomado como "normal", apesar do doente "ficar chateado" e reflete um conjunto de atitudes "desregradas" (tomar chuva, ter "noitada")

9.12. A tuberculose determina a mudança na vida ("não ficar à noite na rua", "não sair", "parar de fumar", "não tomar chuva", "não zoar")

9.13. O tratamento medicamentoso é tido como "normal" e "dificil"

9.14. O tratamento medicamentoso provoca mudança na vida pois termina com o cansaço e faz ganhar peso, determina melhora logo no primeiro dia de ingestão e faz com que a pessoa "se sinta outra"

9.15. O tratamento medicamentoso causa "alergia", "coceira", e "nervosismo", secundário à coceira

9.16. O sucesso do tratamento está atrelado à boa alimentação

9.17. As reações ao tratamento medicamentoso não impedem a sua continuidade

9.18. A necessidade de ingestão dos medicamentos ocorre devido ao não querer re-vivenciar a doença/tb, ao vislumbre do futuro e à vontade de "ficar bom"

9.19. A figura materna e dos demais membros da família ajudam no processo de tratamento

9.20. Mesmo que a doença/tb esteja presente na família, existe a idéia de que a pessoa não será alvo da doença

9.21. A dificuldade do tratamento ocorre devido à quantidade de medicamentos a serem ingeridos

9.22. A tuberculose determinou "prontidão" para a procura de assistência à saúde a partir de sinais e sintomas que anteriormente não eram valorizados ("gripe")

9.23. Seguir o tratamento medicamentoso, determinado pelo médico, é a atitude mais importante

9.24. A protagonista da assistência na UBS é a profissional médica

9.25. O profissional médico é elevado ao status de "pertencer à família", devido à importância do seu papel na condução do tratamento

9.26. A disponibilidade do médico para o paciente é um ponto enfocado como importante

9.27. O medicamento provoca ao mesmo tempo dependência para a cura e dificuldade de torná-lo parte da rotina diária 


\section{ENTREVISTA 10}

Sinais e Sintomas: febre, tosse, rouquidão, emagrecimento

TRAJETÓRIA: sinais e sintomas: (1 mês) $\rightarrow$ Pronto Socorro (PS) Iguatemi $\rightarrow$ Raio $X \rightarrow$ "infecção no pulmão" $\rightarrow$ medicamentos $\rightarrow$ piora $\rightarrow$ PS Iguatemi $\rightarrow$ internação $\rightarrow$ Tuberculose $\rightarrow$ Unidade Básica de Saúde $\rightarrow$ Posto do Plano de Atendimento à Saúde

10.1. A recordação do início da doença/tb tem como referência o surgimento de sinais e sintomas durante o trabalho

10.2. A sintomatologia não está associada à tuberculose, mas sim à outra doença ("gripe"). "tratada" através de medicamento caseiro ("chás")

10.3. A busca da assistência à saúde é determinada pelo empregador

10.4. A tuberculose não é denominada ("essa doença", "esse negócio de doença")

10.5. O doente desconhece a possibilidade de cura da tuberculose

10.6. A assistência hospitalar é protagonizada pelo médico, enquanto que a assistência na UBS é protagonizada por funcionários (não denominados), sem identificação da categoria profissional ("meninas"), pelos médicos (denominados) e pela assistente social (denominada)

10.7. A continuidade do trabalho e a ausência de sintomatologia (após o tratamento) constituem ausência de doença/tb

10.8. O apoio, o estímulo, a receptividade, por parte dos funcionários/médicos da UBS e a realização de visita domiciliária, são importantes para o doente

10.9. O estímulo e o apoio, por parte dos funcionários da UBS, remete à necessidade de gratidão

10.10. A gratidão é direcionada em níveis para o divino e para os funcionários da UBS

10.11. O diagóstico provoca "nervosismo", em decorrência de ser a primeira vez que a doença/tb se manifestava e em virtude do desconhecimento da causa da doença

10.12. A possibilidade de cura provoca "tranqüilidade" e "sossego"

10.13. O tratamento proporciona a melhora da sintomatologia e o surgimento de hepatite medicamentosa

10.14. O seguimento do tratamento ocorre devido ao desejo de cura

10.15. O estímulo dos familiares e amigos é apontado como importante no tratamento (visita, apoio financeiro)

10.16. O preconceito em relação ao doente (“descaso") é concretizado pelo afastamento por parte de algumas pessoas

10.17. O sentimento que envolve o preconceito é remetido ao âmbito divino ("o que eu fiz foi entregar a Deus")

10.18. O doente apresenta sentimento de "culpa" por contrair a doença e desconhecer a fonte de transmissão

10.19. O doente estabelece para si o uso de medidas de proteção contra a transmissão da doença ("separação de vasilhas", pratos, copos, objetos de ordem pessoal) não questionadas pelo profissional médico

10.20. A doença/tb determina o afastamento do uso de objetos comuns no ambiente familiar, a mudança da percepção do doente em relação ao valor das pessoas e a ruptura na vida: antes/após a doença

10.21. Ter tuberculose independe da pessoa ("quando tem que vir não escolhe", "não escolhe nem pobre, nem rico")

10.22. O sucesso do tratamento è imputado à UBS; aos funcionários que apoiam, esclarecem sobre a doença e o tratamento medicamentoso, prestam "boa assistência", e manifestam receptividade para com o doente; è à boa vontade do doente

10.23. O seguimento completo do tratamento é produto da "vontade de viver" e da necessidade de criar os filhos

10.24. O autocuidado à saúde e o estímulo "externo" são tidos como os itens mais importantes do tratamento 


\section{ENTREVISTA 11}

Sinais e Sintomas: "dor no pulmão", perda de peso, dispnéia noturna, inapetência, fraqueza, desânimo

TRAJETÓRIA: sinais e sintomas: ( 15 dias) $\rightarrow$ Hospital da Marinha $\rightarrow$ Raio (R) X rins $\rightarrow$ ? $\rightarrow$ piora $\rightarrow$ RX pulmão $\rightarrow$ internação (5dias) $\rightarrow$ biópsia $\rightarrow$ Tuberculose $\rightarrow$ Unidade Básica de Saúde São Paulo

11.1. A sintomatologia não é associada à tuberculose, mas sim à outra doença ("dor nos rins")

11.2. A busca da assistência à saúde se efetiva a partir do agravamento da sintomatologia

11.3. A acessibilidade à assistência à saúde determina a sua procura imediata

11.4. A doença/tb se caracteriza por um processo de debilitamento físico progressivo (emagrecimento, "desânimo", fraqueza)

11.5. O diagnóstico e a necessidade de realização de procedimentos terapêuticos são revelados à familiar (mãe) e não ao doente adulto

11.6. A UBS é tomada como local onde é distribuída a medicação

11.7. A doença/tb se constitui em "experiência traumatizante" e provoca "medo"

11.8. A doença/tb não é tida como grave, pois é passível de cura, mas derperta para a possibilidade de gravidade de outras enfermidades

11.9. A cura depende do tratamento medicamentoso correto

11.10. A doença/tb se constitui em uma "experiência" válida, pois derperta para a necessidade de precaução de outras doenças

11.11. A doença/tb está relacionada à perda de peso e ao "sofrimento" pela possibilidade de cura "talvez" a longo prazo

11.12. O diagnóstico de tuberculose provoca "abalo" no doente, pois revela a complexidade da doença

11.13. A doença/tb é associada à umidade, ao odor fétido e à ventilação inadequada do ambiente de trabalho e de moradia

11.14. O sucesso do tratamento medicamentoso começou a se efetivar a partir do segundo bimestre

11.15. A melhora do estado de saúde se materializa através do ganho de peso, do aumento da disposição, da melhora da falta de ar e da diminuição da dor

11.16. A doença/tb é um "pesadelo", é "estranha" e se conforma como uma lição

11.17. A doença/tb determina comportamento "diferente" dos outros em relação ao doente ("mais afeto")

11.18. A doença/tb determina o afastamento do trabalho e altera a economia familiar

11.19. O sucesso do tratamento depende do apoio familiar, de otimismo, do seguimento correto do tratamento medicamentoso, de alimentação nutritiva e de disciplina

11.20. O trabalho não ampara economicamente o doente por ocasião da doença e isso causa "decepção"

11.21. O seguimento do tratamento deve-se ao incentivo, à possibilidade de reincidência da doença/tb, à possibilidade de continuidade do afastamento do trabalho e suas repercussões econômicas e à "vontade de cura"

11.22. O desconhecimento sobre a fonte de infecção provoca "medo"

11.23. O protagonista da assistência à saúde, no âmbito hospitalar, é o profissional médico

11.24. O tratamento medicamentoso determina aumento de peso e a alimentação adequada ajuda nesse processo

11.25. A interrupção do tratamento é conduta que só pode ser tomada pelo profissional médico

11.26. A tuberculose não é denominada ("tb", "coisa") 


\section{ENTREVISTA 12}

Sinais e Sintomas: dor nas costas/pernas, tosse, febre, cansaço

TRAJETÓRIA: sinais e sintomas: (4 meses) $\rightarrow$ catapora $\rightarrow$ Hospital Universitário $\rightarrow$ Raio $X$ $(\mathrm{RX}) \rightarrow$ "infecção pulmonar" $\rightarrow$ tratamento (10 dias) $\rightarrow \mathrm{RX} \rightarrow$ exame de escarro $\rightarrow$ ? $\rightarrow 1$ mes $\rightarrow$ sinais e sintomas $\rightarrow$ punção pleural $\rightarrow \mathrm{RX} \rightarrow$ derrame pleural, Tuberculose (TB)? $\rightarrow$ internação $\rightarrow$ biópsia $\rightarrow \mathrm{TB} \rightarrow$ Unidade Básica de Saúde

12.1. A busca da assistência à saúde é deflagrada pela ocorrência de outra doença (catapora)

12.2. A sintomatologia não é associada à doença/tb, mas sim à pneumonia

12.3. Os protagonistas da assistência, no âmbito hospitalar, são o profissional médico e os auxiliares de enfermagem

12.4. O diagnóstico de tuberculose é definido através de exame específico (biópsia de pleura)

12.5. A quantidade de medicamentos provoca "pavor"

12.6. A auxiliar de enfermagem é apontada como profissional que diminui a ansiedade, na medida em que orienta sobre o estágio de contágio da doença e sobre o tratamento medicamentoso

12.7. A internação é valorizada positivamente, por permitir compartilhar a situação de doença com outros que vivenciam o mesmo processo

12.8. A protagonista da assistência na UBS é a profissional médica

12.9. O seguimento do tratamento pelo doente ocorre devido à noção de seriedade que o profissional médico imputa à doença

12.10. O tratamento correto é constituído por horário correto e jejum, quando necessário

12.11. A "decepção/frustração" do doente pela conduta médica, no que se refere à valorização da sintomatologia apresentada pregressamente, determina o atraso na busca da assistência à saúde

12.12. O saber médico não contempla a queixa do doente

12.13. O diagnóstico provoca "abalo/desorientação", pois traz à tona a noção de isolamento

12.14. Tomar a doença como fato normal/do cotidiano ("pega até num ônibus") determina a diminuição de ansiedade

12.15. A incerteza quanto ao conhecimento da fonte de infecção provoca "culpa"

12.16. A doença/tb está associada ao excesso de trabalho, à aglomeração de pessoas em ambientes fechados e à exposição à chuva

12.17. A não divulgação da doença/tb a outros ocorre em decorrência do "receio" de causar "preconceito/incompreensão/pena"

12.18. A doença/tb é tida como fato "anormal" e gera preconceito

12.19. A dúvida sobre o sucesso do tratamento provoca "preocupação" no doente

12.20. O sucesso do tratamento depende do tratamento medicamentoso correto, do tratamento caseiro e da diminuição do trabalho

12.21. Um tratamento alternativo (ervas) é usado simultaneamente ao tratamento medicamentoso

12.22. O tratamento medicamentoso causa reação (vômito), que determina a necessidade de sua interrupção parcial

12.23. O cumprimento da ordem médica depende da relação médico-paciente

12.24. A reação indesejável ao tratamento medicamentoso se concretiza especificamente no estômago, figado e pele

12.25. A necessidade de ingesta diária dos medicamentos é apontada como fator negativo, pois faz lembrar o "estar doente", mas ao mesmo tempo "dá força" para fazer o tratamento

12.26. A doença/tb provoca mudança de hábito (deixar de ingerir álcool) e valorização do corpo e da saúde

12.27. O sucesso do tratamento depende da atenção do profissional médico, de enfermagem e da família (levar ao hospital), da distância da UBS à moradia, da confiança na possibilidade de cura e da sua valorização em função da vida como um bem maior 
12.28. A doença/tb é "algo predestinado"

12.29. O seguimento do tratamento se constitui em obrigação para viver

12.30. Os momentos dificeis vividos durante a doença são minimizados por ocasião da cura

12.31. A possibilidade de cura é delegada ao destino

12.32. O posicionamento do profissional médico favorece o seguimento do tratamento (indagando, prescrevendo, regulando, alertando) 


\section{ENTREVISTA 13}

Sinais e Sintomas: febre início abrupto ( 2 dias), fraqueza, emagrecimento (6 meses)

TRAJETÓRIA: sinais e sintomas $\rightarrow$ Hospital Universitário $\rightarrow$ Tuberculose $\rightarrow$ Unidade Básica de Saúde

13.1. A doença/tb inicia sua manifestação (febre) após situação "emocional", conseqüente ao contato com familiar internado por tuberculose

13.2. A busca da assistência à saúde se dá a partir de um sinal (febre)

13.3. A doença/tb provoca "fraqueza", desânimo, necessidade de repouso, "choque", inapetência e emagrecimento

13.4. A sintomatologia não é associada à doença/tb, apesar do seu conhecimento anterior por parte do doente

13.5. A percepção sobre a gravidade da doença/tb ocorre quando os sinais e sintomas começam a se manifestar

13.6. O doente desconhece a fonte de infecção, mas conhece o seu modo de transmissão (ar)

13.7. Compartilhar o processo saúde-doença com pessoas que vivenciam a mesma doença, com o profissional médico, com os pais e com a assistente social provocam "ânimo/alivio" e estímulo para dar continuidade ao tratamento

13.8. O seguimento do tratamento ocorre pela necessidade e crença na melhora

13.9. A ingestão dos medicamentos provoca "constrangimento", quando há que tomá-los próximo a pessoas que desconhecem a doença/tb, mas isso não impede a continuidade do seguimento do tratamento

13.10. A doença/tb provoca maior atenção/recomendações por parte dos familiares para com o doente

13.11. A doença/tb está associada à exposição ao frio

13.12. A doença possibilita a continuidade da rotina de vida (passear, praticar esporte)

13.13. A doença/tb é divulgada somente para algumas pessoas mais próximas do círculo de convívio (potencialmente capazes de apoiar)

13.14. A proximidade de pessoas e a constatação de que a doença é passível de cura, são apontadas como fatores positivos no tratamento

13.15. Compartilhar a doença com o profissional médico determina a diminuição do afastamento do doente em relação à outras pessoas

13.16. A profissional médica, protagonista da assistência na UBS, contribui para o tratamento, através de estímulo (conversa)

13.17. A quantidade de medicamentos, a sua ingestão diária e a indagação de pessoas sobre a razão de ingerir o medicamento causam "incômodo", mas isso não impede a continuidade do tratamento

13.18. O desejo e a possibilidade de melhora, bem como a possibilidade de sofrer as consequiências da interrupção do medicamento, determinam a sua continuidade

13.19. O ganho de peso, a "disposição", o "ânimo" são tidos como sinais de melhora da doença/tb

13.20. O sucesso do tratamento depende da pessoa pensar, em primeiro lugar, em "si mesma"

13.21. O conhecimento/informação sobre a doença/tb estimulam o seguimento do tratamento

13.24. As informações gerais sobre a doença/tb, divulgadas pela escola, exacerbam o "medo" em relação à doença, na medida em que ela pode causar a morte 


\section{ENTREVISTA 14}

Sinais e Sintomas: escarro, calafrios, "corpo mole", cansaço, desânimo, sudorese, febre, inapetência, insônia, abatimento, emagrecimento, palidez, tosse

TRAJETÓRIA: sinais e sintomas $(8$ dias $) \rightarrow$ clínica particular Santo Amaro (otorrinolaringologista) $\rightarrow$ Raio $X \quad(\mathrm{RX}) \rightarrow$ pneumonia $\rightarrow$ Keflex, Teldane $\rightarrow$ Hospital Universitário $\rightarrow$ "especialista" em doenças pulmonares $\rightarrow \mathrm{RX} \rightarrow$ pneumonia $\rightarrow$ Antibióticos $\rightarrow$ mudança de antibióticos $\rightarrow$ punção pleural $\rightarrow$ exame de escarro $\rightarrow$ ? $\rightarrow$ exame de escarro $\rightarrow$ Tuberculose $\rightarrow$ Unidade Básica de Saúde

14.1. A manifestação da doença/tb é associada com a atividade de trabalho

14.2. A presença de um sinal (escarro) não define a necessidade de busca de assistência à saúde

14.3. A doença provoca interrupção das atividades relativas ao trabalho

14.4. O diagnóstico médico é definido a partir de "poucas perguntas"

14.5. A sintomatologia debilitante não provoca "abatimento"

14.6. A piora do quadro sintomatológico determina a busca de outro serviço de saúde

14.7. O protagonista da assistência, no âmbito hospitalar, é o profissional médico, especialista, denominado, e a assistente social; no âmbito da UBS, é a profissional médica

14.8. A internação de urgência para o profissional médico pauta-se na manifestação grave da doença e, para o doente, pauta-se na interrupção das atividades do cotidiano

14.9. O acesso à internação depende da comprovação de residência na área geográfica do hospital e se constitui em obstáculo a ser transposto pelo doente, apesar da determinação médica

14.10. O tratamento medicamentoso e a boa alimentação não provocam a melhora do quadro sintomático

14.11. A ingestão de alimentos, ainda que sem gostar, é tida como um dever para atingir a cura

14.12. A infra-estrutura hospitalar não permite o cumprimento do tratamento durante a internação (banho: água fria no HU)

14.13. O doente necessita de "preparo" prévio para a internação hospitalar ("tomar banho", "me trocar")

14.14. A internação determina um relacionamento de "amizade" entre o médico e o doente

14.15. Há desvalorização do saber do doente pelo profissional médico na definição do diagnóstico 14.16. O apoio/estímulo, no sentido de ter confiança na possibilidade de melhora, por parte dos familiares do doente, ajuda a enfrentar a situação de debilidade crescente em função da doença/tb 14.17. A doença/tb é interpretada como "passageira", "coisa feia" e "dificil", pelos familiares do doente

14.18. O apoio/estímulo por parte dos familiares não impede a sensação de desânimo e de doença 14.19. A não melhora do quadro incentiva o questionamento do doente em relação à conduta médica

14.20. Para o doente, o ambiente hospitalar piora a evolução da doença

14.21. A eclosão de outra doença, concomitantemente à outra já instalada, é entendida como "negligência médica"

14.22. A expectativa do doente sobre a ação médica é o controle da doença e a prevenção de outras enfermidades

14.23. A doença limita a realização de atividades rotineiras

14.24. Os procedimentos de isolamento e a prescrição de medicamentos são transmitidos ao doente, mas o diagnóstico não é comunicado

14.25. A desinformação provoca dúvidas e a imaginação de estar acometido por doença grave (AIDS)

14.26. O agravamento da sintomatologia faz a equipe de saúde e os familiares pensarem em AIDS 
14.27. As medidas de isolamento executadas pela equipe de saúde provocam "ambigüidade" no doente sobre a verdadeira doença que o acomete (suspeita de AIDS)

14.28. A desinformação incentiva o doente a buscar esclarecimento, junto ao profissional de saúde, sobre o seu diagnóstico

14.29. A busca de informações é feita junto à assistente social e não ao médico, qualificado como "amigo"

14.30. A ausência de diagnóstico causa "preocupação", maior do que a relacionada à doença/tb propriamente dita

14.31. A desinformação sobre o resultado de exame para deteç̧ão de AIDS, provoca "preocupação"

14.32. A rotina hospitalar impede a conciliação do sono

14.33. A realização de exames para a detecção de HIV é permeada pelo segredo, estabelecido em primeira instância pelo médico

14.34. O resultado negativo do teste para detecção de HIV provoca "despreocupação"

14.35. O terceiro dia de tratamento medicamentoso para tuberculose provoca melhora, concretizada pelo ganho de peso e conciliação do sono

14.36. A prorrogação do período de internação provoca questionamento, por parte do doente, da conduta médica, mas a medida é imediatamente acatada

14.37. A proposição de apoio "religioso" por parte de familiar é recusada pelo doente, mas posteriormente é acatada

14.38. A "falha" no cumprimento da obrigação "religiosa", destinada à cura, provoca "preocupação" no doente

14.39. Há crença de que a entidade divina promove a melhora e a cura

14.40. O familiar remete ao plano espiritual a ajuda ao doente

14.41. A responsabilidade pelo sucesso do tratamento, se devida à ação médica ou à ação divina, provoca sentimento de ambigüidade por parte do doente

14.42. A ausência de reação medicamentosa é imputada à "ajuda" de órgão (estômago)

14.43. As orientações médicas, por ocasião da alta, concentram procedimentos a serem executados durante o primeiro bimestre de tratamento para a não transmissão da doença, além da necessidade de seguir o tratamento medicamentoso

14.44. O diagnóstico causa "contentamento" pela "descoberta" da doença/tb

14.45. A apreensão da doença/tb como um processo "normal" determina o sentimento de não discriminação

14.46. Para o doente. a doença/tb não modifica a vida

14.47. A concepção de que a vida existe fora do plano terrestre relativiza a noção de vida e de saúde

14.48. O sucesso do tratamento é atribuído à "fé", ao plano espiritual

14.49. A "proteção espiritual", que ajuda o tratamento, é obtida pelas "boas ações das pessoas"

14.50. A doença é provocada por "vingança", por "entidade que causa o mal"

14.51. Os ambientes hospitalar, médico e religioso encontram-se protegidos do "mal"

14.52. O comportamento "bom" e a "disciplina" não levam à doença

14.53. A doença determina, por parte do doente, a valorização dos familiares, a melhora do relacionamento com as pessoas e a desvalorização de aspectos materiais

14.54. A doença e os problemas econômicos não provém do acaso, mas eles ocorrem para valorizar a vida

14.55. O seguimento do tratamento ocorre pela auto-estima, por acreditar que os membros familiares necessitam do doente, do afeto familiar, da concepção da vida como um bem superior e que deve ser valorizado e devido à vontade de viver

14.56. Ao profissional médico compete "fazer o bem à humanidade e salvar vidas"

14.57. A vida é originada do divino e só este detém o poder de tirá-la

14.58. O sucesso do tratamento está associado ao seguimento do tratamento medicamentoso, à não ingestão de álcool e uso de fumo, ao não uso de drogas, ao entendimento de que a força para executá-lo provém do próprio indivíduo e de ter vontade de viver 
14.59. A cura da doença/tb é imputada à ciência

14.60. A evolução da doença para piora, antes imputada aos médicos, é "desculpada" pelo doente, na medida em que os fatos/doença, ocorrem por responsabilidade das próprias pessoas

14.61. O doente acredita que as ações de saúde, realizadas em regiões geográficas localizadas na periferia, são "espirituais" e voltadas ao homem 


\section{ENTREVISTA 15}

Sinais e Sintomas: febre, cansaço, sudorese, dor no peito, fraqueza, emagrecimento, perda de apetite, sede, tosse, insônia

TRAJETÓRIA: sinais e sintomas $(15$ dias $) \rightarrow$ Hospital Universitário $\rightarrow$ Raio $\mathrm{X} \rightarrow$ Tuberculose $\rightarrow$ Unidade Básica de Saúde

15.1. A sintomatologia no início da doença não é associada à tuberculose ("resfriadinho" passageiro) e é "controlada" através de aspirina/novalgina e de procedimentos caseiros

15.2. A busca da assistência à saúde não ocorre por ocasião do início da manifestação da sintomatologia, mas devido à impossibilidade de interrupção das atividades relativas ao trabalho 15.3. A fonte de infecção é desconhecida pelo doente ("ônibus, ar")

15.4. O diagnóstico provoca "medo", em decorrência da idéia da necessidade de internação (Campos do Jordão)

15.5. A gravidade da doença/tb determina a crença da impossibilidade de realizar o tratamento no âmbito domiciliar

15.6. O doente associa a possibilidade de não cura da doença/tb, à sua fragilidade física pregressa, provocando "medo"

15.7. A doença/tb provoca "nervosismo", "abalo do sistema nervoso", "medo", devido à possibilidade de ter que interromper as atividades de trabalho e, em decorrência, diminuição do poder econômico e da necessidade de cumprimento das "obrigações domésticas" (alimentar, vestir e dar medicação aos filhos)

15.8. A doença/tb é divulgada pelo doente no ambiente de trabalho indiscriminadamente

15.9. A doença/tb causa interrupção das atividades relativas ao trabalho (6 meses)

15.10. O tratamento medicamentoso provoca a melhora da sintomatologia em uma semana

15.11. O tratamento medicamentoso é considerado "horrivel" no início, devido ao tamanho dos comprimidos e à necessidade de sua ingestão com leite

15.12. O seguimento do tratamento é apoiado pelos familiares (visita, incentivo para ir às consultas médicas)

15.13. O protagonista da assistência, no âmbito hospitalar, é o profissional médico (não denominado)

15.14. O tratamento medicamentoso provoca alterações no organismo ( do ciclo menstrual)

15.15. A doença/tb determina a valorização da saúde (parar de fumar, controle da exposição ao frio), a limitação das atividades relativas ao trabalho, e essas condutas são estimuladas pelos colegas de trabalho

15.16. A doença ocorre quando a vida começa a ser "disciplinada" e isso provoca "surpresa"

15.17. A doença é associada à mudança de temperatura

15.18. A necessidade de freqüentar as consultas médicas é apontada como fator negativo para o doente

15.19. A disponibilidade da assistente social e compartilhar sobre a doença com funcionários da UBS são apontadas como positivas para o seguimento do tratamento

15.20. A mudança da equipe de saúde na UBS é apontada como negativa no seguimento do tratamento, na medida em que promove o distanciamento da nova equipe no relacionamento com o doente

15.21. A protagonista da assistência na UBS é a assistente social (denominada) e os funcionários (não denominados)

15.22. O vínculo do doente com a UBS é rompido com a implementação do PAS, uma vez que provoca a mudança da equipe de saúde

15.23. O seguimento do tratamento ocorre por "amor à vida"

15.24. O sucesso do tratamento depende da associação entre boa alimentação, uso dos medicamentos, apoio familiar e apoio de profissional da UBS (psicóloga) 
15.25. A doença/tb é vista como "dificil", "assusta", "não é simples", pois acomete o pulmão, considerado o segundo órgão vital, depois do coração

15.26. A doença/tb provoca "prontidão" para a busca de assistência à saúde, a partir de quaisquer sinais e sintomas

15.27. A doença/tb provoca limitação de movimentos do corpo (devido à dor) e a limitação da realização de atividades cotidianas 


\section{ENTREVISTA 16}

Sinais e Sintomas: tosse, dor nas costas/pernas, escarro, emagrecimento, inapetência, cansaço, febre

TRAJETÓRIA: sinais e sintomas ( 2 anos $) \rightarrow$ Hospital Universitário $\rightarrow$ Unidade Básica de Saúde

16.1. A sintomatologia inicial não é associada à tuberculose ("rins")

16.2. A doença/tb provoca diminuição da capacidade para o desempenho das atividades do cotidiano

16.3. O diagnóstico provoca "medo", "nervosismo" e "preocupação"

16.4. A sintomatologia é associada à tuberculose por membro familiar

16.5. O tratamento provoca melhora e "faz viver"

16.6. A doença/tb está associada ao emagrecimento e à perda de apetite

16.7. O seguimento do tratamento adequado ocorre devido à prontidão/alerta para tomar os medicamentos e porque o organismo "se acostuma" aos medicamentos

16.8. A doença/tb provoca mudança na vida, baseada no desprezo/distanciamento/discriminação, também vividos por aqueles que convivem com a doente

16.9. A tuberculose não é denominada ("minha doença")

16.10. Há conhecimento, por parte do doente, sobre a possibilidade de cura a partir do seguimento do tratamento

16.11. O sucesso do tratamento depende do apoio familiar e da vizinhança (para levar ao médico)

16.12. O desejo de cura motiva o seguimento do tratamento

16.13. O tratamento medicamentoso provoca "reação" (dor no estômago) que não impede a sua continuidade 


\section{ENTREVISTA 17}

Sinais e Sintomas: fraqueza, dores nas costas, desânimo, falta de apetite, tosse, catarro, febre, emagrecimento

TRAJETÓRIA: sinais e sintomas (meses) $\rightarrow$ Hospital Militar $\rightarrow$ medicamento para fraqueza (30 dias $) \rightarrow$ Hospital Militar $\rightarrow$ Raio $X \rightarrow$ Tuberculose $\rightarrow$ exame de escarro + PPD $\rightarrow$ Unidade Básica de Saúde

17.1. A manifestação da doença/tb não ocorre imediatamente à sua "instalação no organismo"

17.2. A doença/tb é causada por mudanças bruscas de temperatura (exposição ao frio) e ao debilitamento do organismo

17.3. A busca da assistência à saúde é determinada pela sintomatologia, mas ela não é explicitada integralmente, por parte do doente, ao profissional médico

17.4. Para o doente, a sintomatologia é causada por excesso de trabalho

17.5. A sintomatologia é associada à tuberculose, em virtude de ter experimentado a doença em amigo e, por outros, é vista como "normal"

17.6. Há desconhecimento, por parte do doente, em relação à doença/tb

17.7. A busca da assistência à saúde ocorre somente na situação-limite (dor profunda nas costas, febre) e por insistência de amigo

17.8. O diagnóstico provoca "apreensão", pois o doente associa a doença/tb à contagiosidade, ao afastamento, ao isolamento de objetos (para alimentar-se) e à possibilidade de discriminação

17.9. O protagonista da assistência, no âmbito hospitalar é o médico (denominado) e na UBS é a médica (denominada), caracterizada pela etnia, por ser "atenciosa", "conversar" e orientar

17.10. A orientação médica salienta a necessidade da não interrupção do tratamento medicamentoso, do esclarecimento de que a melhora da sintomatologia não traduz a cura e salienta que o seguimento do tratamento leva a uma possibilidade de normalização da vida e de não transmissão da doença

17.11. A profissional médica evidencia a doença/tb através de imagens ("crateras")

17.12. A representação da doença/tb que é veiculada pelo profissional médico, provoca sensação de "arrepio" no doente

17.13. As orientações médicas esclarecem sobre o modo de transmissão da doença/tb e sobre a indiscriminação de sua fonte de transmissão

17.14. Para a doente, a concepção comum de tuberculose é a de que a doença leva, necessariamente, à internação em hospitais de isolamento

17.15. A possibilidade de se realizar o tratamento no âmbito domiciliar é qualificada como "ótima"

17.16. A doença/tb provoca discriminação, afastamento das pessoas e a separação de objetos

17.17. A tuberculose é denominada como "essa doença", qualificada por "horrivel" e que "provoca dor"

17.18. A AIDS é considerada "pior" que a tuberculose pois não tem cura

17.19. A possibilidade de cura baliza a noção de gravidade

17.20. A discriminação ocorre pois as pessoas pensam tratar-se de AIDS e não de tuberculose

17.21. O ganho de peso e o aumento da disposição durante o tratamento, são indicadores de melhora da doença/tb e conseqüente reaproximação das pessoas

17.22. O seguimento do tratamento é qualificado como "dificil" no primeiro bimestre, pois os medicamentos causam reação (azia)

17.23. A diminuição dos efeitos das reações dos medicamentos é obtida através da "boa alimentação" (não tomar o medicamento com leite)

17.24. Os "conselhos médicos" sobre a possibilidade de reincidência da doença, com a piora do quadro e a ameaça de morte, contribuem para a não interrupção do tratamento

17.25. O tratamento medicamentoso é seguido segundo uma base de regularidade horária 
17.26. A tuberculose provoca mudança na vida, no sentido de questionar a forma como as pessoas a levam, de valorizá-la, de cuidar da saúde (parar de fumar, boa alimentação, deixar de ser hipocondríaca)

17.27. A tuberculose faz perceber a fragilidade do organismo

17.28. A tuberculose é provocada por deficiência da alimentação

17.29. O seguimento do tratamento é produto de estímulo de amigo e do profissional médico (hospital e UBS)

17.30. O estímulo do profissional médico é caracterizado como "conversa" (durante o exame fisico) e de "tornar normal o processo da doença", apesar da sua pequena disponibilidade de tempo durante a consulta médica

17.31. A doença/tb não é divulgada

17.32. O tratamento proporciona melhora da tuberculose em um mês de seguimento

17.33. O sucesso do tratamento se deve ao esforço da doente (para alimentar-se) e ao apoio de familiares (preparando alimentos)

17.34. O seguimento do tratamento é determinado pelo valor dado à saúde e à vida, devido ao esforço do próprio doente, devido à projetos/objetivos relativos ao futuro, à possibilidade de voltar ao "estado normal", da consciência/noção sobre a necessidade do tratamento, e é definido por "regras" ("não tomar a medicação com leite")

17.35. A tuberculose provoca limitação de locomoção devido à dor e necessidade de paralisação das atividades relacionadas ao trabalho

17.36. A incorporação das orientações e do estímulo (preparar alimentos, promover transporte, alimentação nutritiva) para o seguimento do tratamento, dependem de cada pessoa 


\section{ENTREVISTA 18}

Sinais e Sintomas: febre, lesão na "nádega"

TRAJETÓRIA: sinais e sintomas $\rightarrow$ Hospital Universitário (Raio X) $\rightarrow$ Tuberculose $\rightarrow$ Hospital Sarah (exame de escarro $\rightarrow$ Unidade Básica de Saúde

18.1. O início da doença/tb é associado à "coisa que tava me furando" ("lesão nas nádegas")

18.2. O tratamento se reduz ao fato de "pegar os medicamentos" na UBS

18.3. Os protagonistas da assistência, no âmbito hospitalar, são a enfermeira (não denominada) e o profissional médico (denominado), enquanto que na UBS é protagonizada pela profissional médica (denominada) e pelos demais funcionários, sem a definição de sua categoria profissional ( "moça que pega a medicação")

18.4. A doença/tb não é mencionada ("problema", "assunto")

18.5. A doença/tb progride no interior do organismo ("... desceu em vez de ficar no pulmão")

18.6. A doença é causada por exposição a ambiente frio, desgaste físico e ingestão de álcool

18.7. Há desconhecimento anterior, por parte do doente, sobre a tuberculose

18.8. O diagnóstico é tomado sob a forma de "obediência" à palavra do profissional médico

18.9. O tratamento medicamentoso determina melhora, concretizada pela ausência de dor nas costas e nas pernas

18.10. O tratamento medicamentoso é seguido em função do tempo (o relógio é a concretização da necessidade de ingerir o medicamento)

18.11. O tratamento medicamentoso provoca reação que não impede a sua continuidade

18.12. O tratamento é assumido pelo doente resignadamente, como uma necessidade imperiosa, sem alternativa

18.13. A doença não é divulgada a vizinhos

18.14. A UBS é apontada como importante no tratamento pois fornece os medicamentos

18.15. A figura do médico (do nível hospitalar) é apontada como importante, pois tem conhecimento sobre a doença

18.16. A figura da médica (da UBS) é apontada como importante na medida em que cura a doença/tb

18.17. O doente remete ao âmbito divino a gratidão para com o profissional médico sob a forma de longevidade e saúde

18.18. O doente manifesta sentimento negativo em relação aos funcionários da UBS, uma vez que controlam o acesso (número de vagas) dos doentes à unidade de saúde

18.19. O tratamento medicamentoso é feito integralmente pelo doente na perspectiva de melhora

18.20. O seguimento correto do tratamento medicamentoso é o mais importante a ser feito para a cura

18.21. O tratamento medicamentoso é incorporado ao cotidiano

18.22. A melhora da doença/tb é balizada pelo ganho de peso 